\title{
Late Paleogene - Early Neogene Abandoned Rift along the River Nile, Egypt
}

\author{
Dissertation \\ zur Erlangung des mathematisch-naturwissenschaftlichen Doktorgrades \\ "Doctor rerum naturalium" \\ der Georg-August-Universität Göttingen \\ im Promotionsprogramm Geowissenschaften \\ der Georg-August University School of Science (GAUSS)
}

Vorgelegt von

\author{
Ali Abdelkhalek \\ aus $\ddot{A} g y p t e n$
}

Göttingen, 2020

Abteilung Strukturgeologie und Geodynamik

Geowissenschaftliches Zentrum

Georg-August-Universität 


\section{Betreuungsausschuss}

Prof. Dr. Jonas Kley (Abteilung Strukturgeologie und Geodynamik, Geowissenschaftliches Zentrum Georg-August-Universität, Göttingen).

Assoc. Prof. Dr. Mohamed Saleh Hammed (Structural geology and tectonics, Geology Department, Faculty of Science, Cairo University).

Dr. Reinhard Gast (Consultant in Petroleum geology, Sedimentology, Structural Geology and Seismic Interpretation; Honorarprofessor 2013-2017 in Frankfurt).

\section{Mitglieder der Prüfungskommission}

Referent: Prof. Dr. Jonas Kley (Abteilung Strukturgeologie und Geodynamik, Geowissenschaftliches Zentrum Georg-August-Universität, Göttingen).

Korreferent: Assoc. Prof. Dr. Mohamed Saleh Hammed (Structural geology and tectonics, Geology Department, Faculty of Science, Cairo University).

\section{Weitere Mitglieder der Prüfungskommission:}

Prof. Dr. Hilmar von Eynatten (Abteilung Sedimentologie und Umweltgeologie, Geowissenschaftliches Zentrum, Georg-August-Universität, Göttingen).

Dr. Reinhard Gast (Consultant in Petroleum geology, Sedimentology, Structural Geology and Seismic Interpretation; Honorarprofessor 2013-2017 in Frankfurt).

Dr. Klaus Wemmer (Abteilung Geochemie und Isotopengeologie, Geowissenschaftliches Zentrum, Georg-August-Universität, Göttingen).

Dr. Bernd Leiss (Abteilung Strukturgeologie und Geodynamik, Geowissenschaftliches Zentrum, Georg-August-Universität, Göttingen).

Dr. Bianca Wagner (Abteilung Strukturgeologie und Geodynamik, Geowissenschaftliches Zentrum, Georg-August-Universität, Göttingen).

Tag der mündlichen Prüfung: February 23, 2021. 


\section{Promovierenden-Erklärung \\ der Georg-August-Universität Göttingen}

Name: Ali Abdelkhalek Sayed Mohamed

Anschrift: Robert-Koch-Str. 38. App.414, Göttingen

Ich beabsichtige, eine Dissertation zum Thema

Late Paleogene - Early Neogene Abandoned Rift along the River Nile, Egypt.

an der Georg-August-Universität Göttingen anzufertigen.

Dabei werde ich von Herrn Prof. Dr. Jonas Kley; Dr. Reinhard Gast; Assoc. Prof. Dr. Mohamed Saleh Hammed betreut.

Ich gebe folgende Erklärung ab:

1. Die Gelegenheit zum vorliegenden Promotionsvorhaben ist mir nicht kommerziell vermittelt worden. Insbesondere habe ich keine Organisation eingeschaltet, die gegen Entgelt Betreuerinnen und Betreuer für die Anfertigung von Dissertationen sucht oder die mir obliegenden Pflichten hinsichtlich der Prüfungsleistungen für mich ganz oder teilweise erledigt.

2. Hilfe Dritter wurde bis jetzt und wird auch künftig nur in wissenschaftlich vertretbarem und prüfungsrechtlich zulässigem Ausmaß in Anspruch genommen. Insbesondere werden alle Teile der Dissertation selbst angefertigt; unzulässige fremde Hilfe habe ich dazu weder unentgeltlich noch entgeltlich entgegengenommen und werde dies auch zukünftig so halten.

3. Die Richtlinien zur Sicherung der guten wissenschaftlichen Praxis an der Universität Göttingen werden von mir beachtet.

4. Eine entsprechende Promotion wurde an keiner anderen Hochschule im In- oder Ausland beantragt; die eingereichte Dissertation oder Teile von ihr wurden nicht für ein anderes Promotionsvorhaben verwendet.

Mir ist bekannt, dass unrichtige Angaben die Zulassung zur Promotion ausschließen bzw. später zum Verfahrensabbruch oder zur Rücknahme des erlangten Grades führen.

Göttinegn

$21 / 12 / 2020$

Ali AbdelKhralek 


\begin{abstract}
The River Nile is one of the major fluvial systems in the world. The Egyptian Nile has been the most studied part of the river. However, the origin, tectonic style and geodynamic evolution of the Nile are still widely questionable. Several studies have interpreted the river as an erosional feature, while few others believe that its origin might be connected or related with intracontinental rifting processes. It was also suggested that the Nile and its drainage systems were originated by gradual uplift, volcanism and dynamic topography. These processes were, in turn, rolled by the geodynamics of deep mantle plumes. This study suggests a new rift model for the River Nile in Egypt, in which the results of multiple surface and subsurface datasets were used.
\end{abstract}

The results of interpretation and analysis of gravity, magnetic, and recently acquired high-resolution 2D and 3D seismic reflection datasets were integrated with fieldwork studies and processing algorithm techniques of multispectral satellite images and radar data (e.g. Landsat-8, Sentinel-2, ASTER and ALOS-PALSAR) as well as interpretation of Digital Elevation and Terrain Models (DEMs \& DTMs) of different spatial resolutions ( 225, 90, 30, $12.5 \mathrm{~m})$ (e.g. SRTM, AW3D30 and TanDEM-X).

The onset of the main rifting phase that controlled the evolution of the Nile Valley and its drainage was contemporaneous with the initiation of the Red Sea-Gulf of Suez and East African rift systems during the Oligocene $\sim 30-28 \mathrm{Ma}$, and the concomitant regional uplifting processes, terrain exhumation and volcanism of the eastern Red Sea-Gulf of Suez hills. Both the ancestral and present-day drainage systems of the River Nile in Egypt have probably evolved along the Late Paleogene-Early Neogene rift system of NW to NNW orientation. The proposed rift segments and their bounding faults might have been aborted at a very early "embryonic" stage.

Interpretation of gravity and magnetic anomaly models combined with reflection seismic data revealed structures and crustal thickness variations suggesting that several rift basins occur beneath and around the modern Nile Valley. Three main Late Paleogene-Early Neogene rift segments-trending NW and NNW can be characterized along the eastern and western shoulders of the river. These rift segments and their bounding faults were rejuvenated along NW- to NNW-oriented intracontinental half-graben basins that formed earlier during the Early Cretaceous rifting. The rift segments are separated and terminated by oblique/orthogonal E-ENE to NE-trending transfer/accommodation zones. The central and northern segments are geometrically well defined and semi-parallel to the Late Oligocene Red SeaGulf of Suez rift system with a dominant NNW trend, while the southern segment has a prevalent NW orientation with an oblique complex-pattern as a result of the interference between pre-existing structures of E-W, NE, N-S and NW trends. An extensive network of widespread normal faults, related folds, fractures, linear narrow grabens and volcanism accommodated the deformation along the Nile Valley. The NW- to NNW-oriented drainage systems of the ancestral Nile in Egypt have probably originally evolved along these intracontinental rift segments.

Evidences were found of the "reactivated-rift" along numerous grabens within the eastern and western Eocene limestone plateaux of the modern Nile Valley; among them are the early syn-rift gravels, fluvial clastics and red beds of Oligocene age, hundreds of NW and NNW-striking extensional faults, fractures, extensional fault-related folding, and Oligo-Miocene age rift-related basalt dikes and flows at $\sim 25-23$ Ma. In addition, NW elongated "forced anticlinal folding" could be mapped within the faulted shoulders of the rift segments. These are made up of steeply dipping and rotated pre-rift Eocene and Cretaceous rocks, and were formed by local uplift, which in turn was driven by vertical uprising of the volcanic intrusions. Furthermore, analysis of high-resolution DEMs revealed a network of km-scale inverted Oligocene gravel-filled channels within the Eocene carbonates of the Nile Valley. Several channel outcrops are covered with a thick layer of dust and other debris where it is quite hard to characterize them, even on high-resolution Google Earth imagery. However, the results of applying spectral reflectance analysis, bands rationing and principal components on satellite data were utilized to distinguish the Oligocene gravel and red sandstone bodies from the hosting carbonate rocks. Presentday inverted channels are useful to reconstruct the fluvial depositional system and possible flow 
direction(s) of the paleo-rivers that filled the Nile grabens and fault blocks during the very early phase of Oligocene intracontinental rifting.

The control of pre-existing structures on the evolution of the proposed Nile rift and the related volcanism is shown by the inherited Precambrian basement structures and morphotectonic features The RN in Egypt offers a good opportunity to study this approach. Analysis of gravity, magnetic, seismic and field data shows a prominent impact of the structural inheritance and morphology of former rifts on the development and geometry of the abandoned Oligocene rift along the RN. It is proposed that the initiation of the river and its drainage was controlled by intracontinental rifting during the Oligocene, whereas its evolution, segmentation and termination were influenced by basement structures and preexisting rift-related faults/folds of the former Cretaceous basins.

The locations of both rift segments and transfer/accommodation zones were strongly influenced by older Mesozoic rift basins. The Late Oligocene Nile rift segments were rejuvenated along intracontinental rift basins and their bounding faults that formed originally during the Early-Late Cretaceous rifting (from south to north; Kharit, Nuqra, KomOmbo, Assiut and Beni Suef basins).

Reactivation of NW-trending Precambrian basement shears (Najd-Kharit Trend) controlled the regional geometry of the southern rift segment. Highly oblique E-W to ENE-trending dextral shear zones along Wadi Assiuty and Qena dome represent two main transfer zones; across them the rift segments and their marginal faults show flipping of their positions and polarities. Further to the north, NE-ENEoriented uplifted ridges, folds, dextral shears, and thickening of the pre-rift Mesozoic sediments terminated the northward propagation of the rift. Most of these features were nucleated during the EarlyLate Cretaceous extension phases in addition to the control of the successive convergence, basin inversion and Syrian Arc wrench tectonics in the Late Cretaceous.

The Neogene Nile in Egypt consequently evolved along a NW to NNW-trending short-lived, intracontinental rift that was initiated by NE-SW extension during the Oligocene $\sim 25-23 \mathrm{Ma}$, and was abandoned at an early stage. Possible reasons for the rift abandonment are:

(1) Progressive concentration of the extension and strain/stress localization onto the Red Sea-Gulf of Suez rift in the east. The transfer of movement on the latter rift system resulted in abortion of the evolving structures in central Egypt, and consequently led to the abandonment of an embryonic rift.

(2) Strain/stress dissipation over wide rift shoulders $>300 \mathrm{~km}$.

(3) Obliquity of many reactivated pre-existing faults to the $\sim 23$ Ma regional ( $660^{\circ} \mathrm{E}$ ) extension, and subsequent termination of newly developed rift-parallel faults.

(4) Rifting confined to thicker (more brittle?) crust along the central part of the Nile.

(5) Further structural control is that the northern rift termination and abortion coincide with oblique ENE to NE-trending "Syrian Arc" structures of the Bahariya-Fayium fold-fault bet, major basalt flows, and northward thickening of the Mesozoic pre-rift sediments of the ENE and NE half-graben basins of the north Western Desert along the Tethyan shelf. Moreover, an increase in the strength of the lithosphere across the Tethyan continental margin could have acted as a barrier to the northward propagation of the rift. 


\section{Zusammenfassung}

Der Nil ist eines der wichtigsten Flusssysteme der Welt. Der ägyptische Teil des Nils war lange Zeit der bekannteste und am besten untersuchte Abschnitt des Flusses. Die Entwicklung, Tektonik und geodynamische Entwicklung des Nils sind jedoch noch weitgehend ungeklärt. Mehrere Studien haben den Fluss als Erosionsrinne interpretiert, während nur wenige andere Studien ergeben haben, dass sein Ursprung mit intrakontinentalen Rifting-Prozessen verbunden sein könnte. Es wurde auch vorgeschlagen, dass der Nil und seine Entwässerungssysteme durch allmähliche Anhebung und Vulkanismus entstanden sein könnte, ausgelöst von Entwicklungen im Mantel ("mantle-plumes"). Diese Studie schlägt eine neues Rift-Modell für das Niltal in Ägypten vor, in das die Ergebnisse mehrerer Oberflächen- und "Subsurface" Datensätze integriert worden sind.

Diese Arbeit präsentiert die Analyse der Gravimetrie, Magnetik und der in jüngerer Zeit gemessenen hochauflösenden seismischen 2D- und 3D-Reflexionsdatensätze. Diese wurden mit Feldkartierungen, multispektralen Satellitenbildern und digitalen Höhen- und Geländemodellen (DEMs \& DTMs) integriert. Als Resultat wird vorgeschlagen, dass sowohl die angestammten als auch die heutigen Entwässerungssysteme des Nils in Ägypten sich wahrscheinlich entlang des Spätpaläogen-FrühneogenRift-Systems mit NW- bis NNW-Orientierung entwickelt haben. Diese Rift-Segmente und ihre Begrenzungsstörungen wurden wahrscheinlich schon sehr früh in einem "Embryonalen" Stadium abgebrochen. Der Beginn der Hauptriftphase, die die Entwicklung des Niltals und seine Entwässerung kontrollierte war zeitgleich mit dem Beginn des Rifting vom Roten Meer und dem Golf von Suez sowie den ostafrikanische Rift-Systemen während des Oligozäns ( 30-28 Ma) und den damit einhergehenden regionalen Hebungen, Geländeexhumierung und Vulkanismus des östlichen Golfs von Suez am Roten Meer.

Interpretation von Gravimetrie- und Magnetik kombiniert mit 2D-Seismik offenbarte Strukturen und Variationen der Kruste, was darauf hindeutet, dass im Bereich des modernen Niltales in Ägypten mehrere Riftbecken existieren. Drei Spät-Paläogen-Frühneogen-Rift-Segmente von NW- und NNWTrends (südlich, zentral und nördlich) lassen sich definieren. Diese Riftsegmente und ihre Grenzstörungen wurden entlang des NW- bis NNW-orientierten intrakontinentalen Halbgraben-Becken neu angelegt, die sich schon früher während der frühen Kreidezeit gebildet haben. Diese Riftsegmente werden durch schräge-orthogonale E-ENE zu NE-Transferstörungszonen getrennt. Das zentrale und das nördliche Segment sind geometrisch gut definiert und verlaufen mit einem dominanten NNW-Trend +- parallel zum spätoligozänen Riftystem des Roten Meer-Golf von Suez, während das südliche Segment eine vorherrschende NW-Ausrichtung aufweist, das mit einem schrägen komplexen Muster auf der Interferenz zwischen bereits vorhandenen Strukturen von E-W-, NE-, N-S- und NW-Trends einhergeht. Damit einhergehend bildete sich ein umfangreiches Netzwerk von normalen Störungen, Falten, Brüchen, linearen schmalen Gräben. Der Vulkanismus nahm die Verformung entlang des Niltals auf. Wahrscheinlich hat sich das NW bis NNW orientierte Entwässerungsnetz des Ur-Nils in Ägypten ursprünglich entlang dieser intrakontinentalen Rift-Segmente entwickelt.

Diese Studie dokumentiert auch Hinweise auf das „reaktivierte Rift“ entlang zahlreicher Gräben im Bereich des östlichen und westlichen eozänen Kalksteinplateaus des modernen Niltals; darunter finden sich frühe Syn-Rift-oligozäne Kiesgesteine, fluviatile Klastika und „Red-beds“. Außerdem treten hunderte NW bis NNW streichende Dehnungsstörungen, -brüche, dehnungsstörungsbedingte Faltung und Oligo-Miozän-zeitliche ( 25-23 Ma) „Basaltspaltenfüllungen“ und -decken auf. Auch NWstreichende Falten, die aus steil abfallenden und gedrehten Eozän- und Kreidefelsen vor dem Rift bestehen, wurden kartiert. Diese wurden bei lokaler Hebung durch vulkanisches Eindringen verursacht. Zusätzlich ergab die Analyse der hochauflösenden DEMs ein Netzwerk von invertierten fluviatilen Channels aus dem Oligozän im km-Maßstab innerhalb der östlichen und westlichen Eozän-zeitlichen Karbonatschultern des Niltales. Obwohl einige Aufschlüsse mit einer dicken Schuttschicht bedeckt sind, lassen sich die Ergebnisse auch auf hochauflösenden Google Earth-Bildern beobachten. Eine Spektralreflexionsanalyse, Bandrationierung und Hauptkomponentenanalyse von Satellitendaten waren hilfreich, um die oligozänen Kiesvorkommen- und roten Sandsteinkörper vom Karbonat zu unterscheiden. Die Kartierung der invertierten fluviatilen Channels ermöglichte die Rekonstruktion des 
Paläoflusssystems inklusive der Fließrichtung in der sehr frühen Phase des intrakontinentalen Rifts im Oligozän.

Die ererbten präkambrischen Grundstrukturen und morphotektonischen Merkmale der Region beeinflussten die Entwicklung und Architektur nachfolgender Rift-Phasen und die Verteilung des damit verbundenen Vulkanismus. Der Nil in Ägypten bietet eine gute Gelegenheit, diesen methodischen Ansatz zu untersuchen. Unsere Analyse von Gravimetrie-, Magnet-, Erdbeben- und Felddaten zeigt einen deutlichen Einfluss der strukturellen Vererbung und Morphologie ehemaliger Riftphasen auf die Entwicklung und Geometrie des ehemaligen Oligozän-Rifts entlang des Nils. Wahrscheinlich ist die Entwicklung des Flusses und seines Entwässerungsnetzes während des Oligozäns durch intrakontinentale Rifting kontrolliert wurden, während seine Entwicklung, Segmentierung und Beendigung durch Basementstrukturen und bereits vorhandene riftbedingte Verwerfungen / Falten der Kreidebecken beeinflusst wurden.

Die Orte sowohl der Rift-Segmente als auch der Transfer- / Akkommodationszonen wurden stark von älteren mesozoischen Rift-Becken beeinflusst. Die Segmente des späten Oligozän-Nils wurden entlang der intrakontinentalen Riftbecken und ihrer Begrenzungsstörungen verjüngt, die ursprünglich während der frühen späten Kreidezeit entstanden waren (von Süden nach Norden; Becken von Kharit NuqraKomOmbo, Assiut und Beni Suef).

Die Reaktivierung von NW-streichenden (Najd Trend) präkambrischen BasementBlattverschiebungsstörungen kontrollierte die regionale Geometrie des südlichen Rift-Segments. Stark geneigte dextrale Scherzonen von E-W nach ENE entlang der Dome von Wadi El Assiuty und Qena stellen zwei Transfer-Störungszonen dar; über denen die Riftsegmente und ihre Randstörungen ein Umdrehen ihrer Positionen und Polaritäten zeigen. Weiter im Norden beendeten NE-ENE-orientierte Hebungen, Falten, dextrale Blattverschiebungen und die Verdickung von prä-rift-mesozoischen Sedimenten beendete die Ausbreitung der Störung nach Norden. Die meisten dieser Merkmale entwickelten sich während der frühen späteren Kreidezeit zusätzlich zur Kontrolle der sukzessiven Konvergenz, der Beckeninversion und der „Wrench“-Tektonik des syrischen Bogens in der späten Kreidezeit.

Daraus folgt, dass sich der neogene Nil in Ägypten entlang eines von NW nach NNW verlaufenden, kurzlebigen intrakontinentalen Störung entwickelt hat, die durch die NE-SW-Erweiterung während des Oligozäns 24-25 Ma ausgelöst wurde und frühzeitig aufgegeben wurde. Mögliche Gründe für die Aufgabe der Störung sind:

(1) Fortschreitende Konzentration der Ausdehnung und der Lokalisierung von Belastungen / Spannungen im Rotes Meer-Golf von Suez-Rift, wo die Transferstörungstrends dieses Rift-Systems die Ausdehnung in Zentralägypten und damit eine embryonale Störung beendete.

(2) Dehnungs- / Spannungsabbau über breite Riftschultern $>300 \mathrm{~km}$.

(3) Neigung vieler reaktivierter, schon vorher bestehender Störungen zur regionalen $\sim 23 \mathrm{Ma}\left(\mathrm{N} 60^{\circ} \mathrm{E}\right)$ Extension mit sich neu entwickelnden riftparallelen Störungen.

(4) Riftbildung in einer dickeren (spröderen?) Kruste entlang des zentralen Teils des Nilbeckens.

(5) Eine weitere strukturelle Kontrolle besteht darin, dass das Ende des nördlichen Riftbeckens von den ENE-NE-streichenden Strukturen des „Syrian Arc“ der „Bahariya-Fayium-Fold-Fault“-Netzes, den großen Basaltergüssen und der Verdickung der Sedimente vor der Störung nach Norden und der ENE - NE streichenden Halbgrabenbecken der nordwestlichen Wüste entlang des ehemaligen Tethys-Schelfs zusammenfällt. Darüber wird wahrscheinlich eine Zunahme der Lithosphärenmächtigkeit über dem Kontinentalrand der Tethys ein Hindernis für die Ausbreitung der Störung nach Norden gewesen sein. 


\section{Acknowledgements}

I'd like to express my deepest gratitude to my supervisors Prof. Dr. Jonas Kley, Assoc. Prof. Mohamed Saleh Hammed and Dr. Reinhard Gast for their continuous guidance and inspiring supervision during my PhD study. I'm also very grateful to my supervisor Prof. Dr. Adel Sehim, Cairo University, who passed away during the early phase of my thesis. I'd like to deeply thank him for his extremely valuable early ideas, brainstorming questions, and primary preparation with Dr. Hammed for this project; we have started this Journey together. My supervisors, your significant suggestions, recommendations, discussions and comments have strongly improved my academic and research skills. Dear Prof. Jonas, I would like to specially thank you for your great efforts, encouragement and discussions with infinite patience and inspirational debates during our longlasting meetings. Many thanks for supporting me by all means to attend workshops, seminars, international conferences to present the emerging results and outcomes of this project.

My sincere appreciation goes to all members of the Department of Structural Geology and Geodynamic, Geoscience Centre, Georg-August-University, Göttingen, for the healthy work environment that they provide to all researchers and fellows. Thanks for your friendly and helpful comments on my work during seminars and internal meetings. Special thanks to my colleagues David, Elco, Bernd, Bianca, Martin, Renas, Sofia, Tim and Jan. Thank you all for the enjoyable time and pleasant discussions during our talks and lunch/coffee breaks. I'm very grateful to my colleague and friend Jens Walter for his fruitful discussions and motivating advices all the way through my work as well as his continual encouragement to finish this study.

A very special gratitude goes out to my dear friend Ahmed Abdel-Moaty, Geology Department, Cairo University for his great effort, patience and enthusiasm during the hard field studies in the very warm days of the Egyptian summer. I'd like also to thank professors and staff members at the departments of Geology in Minia and Assiut Universities for their help during my fieldwork seasons.

I'd like to present my sincere thankfulness to Dr. Klaus Wemmer, Dr. Nicole Nolte, Dr. Jens Walter Department of Geochemistry and Isotope Geology, for their valuable work through the K/Ar agedating and CIP-MS geochemical analysis of the Basalt samples. Many thanks to Mrs. Brigitte Dietrich and Mrs. Sabrina Neumann for their great efforts in the Laboratory measurements and preparations of the rock samples. Dear Dr. Klaus Wemmer, thank you so much as being responsible for the whole-rock K/Ar age-dating of the basalt samples at your laboratory.

I truly acknowledge the German Academic Exchange Service (DAAD) for funding me with the German Egyptian Research Long-term Scholarship (GERLS) during my stay in Göttingen, Germany (DAAD Full Grant 57222240).

And finally, last but by no means least, I'd like to express my deepest gratitude to my mother for her unfailing support and prayers over the years. I could not be able to finish my studies without her great support. I am also grateful to my other family members and friends who have supported me along the way. 


\section{Contents}

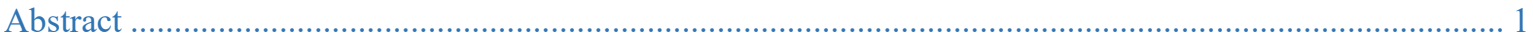

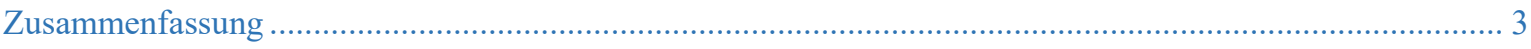

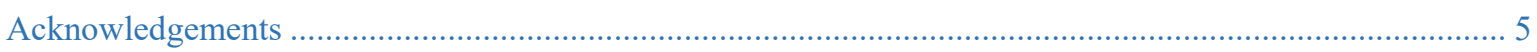

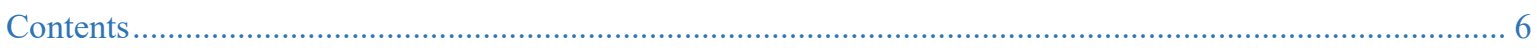

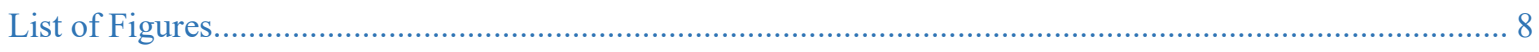

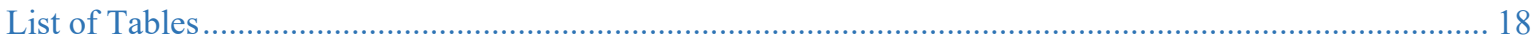

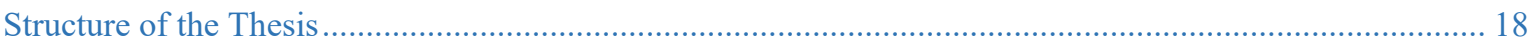

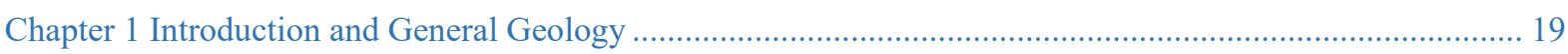

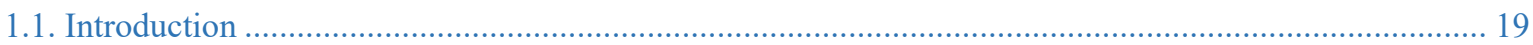

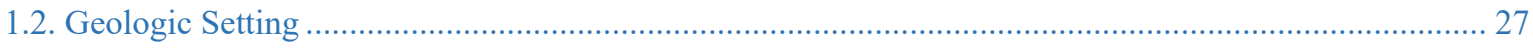

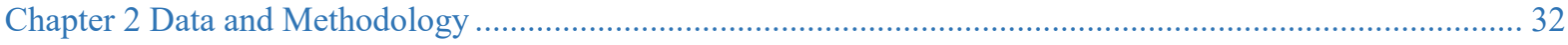

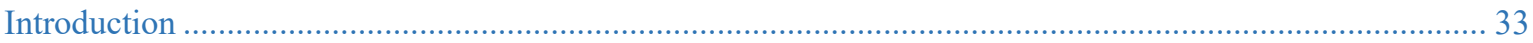

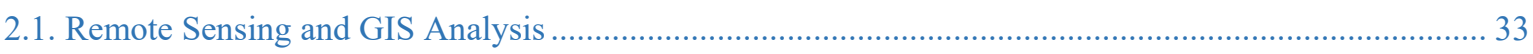

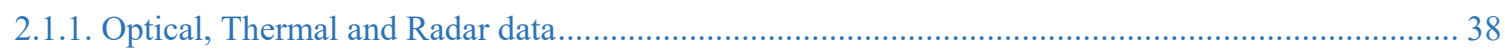

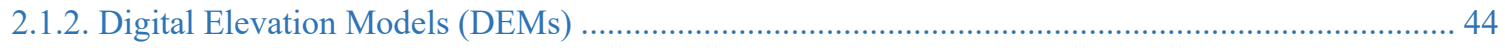

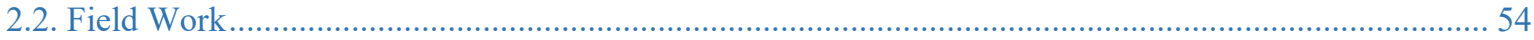

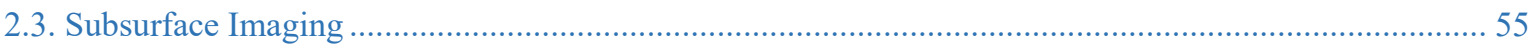

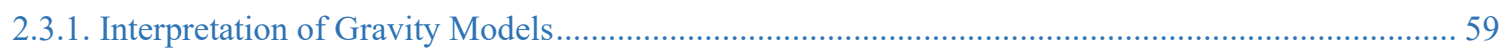

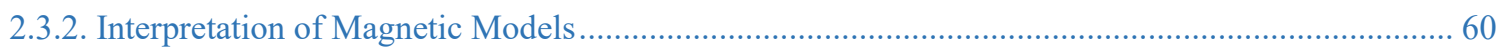

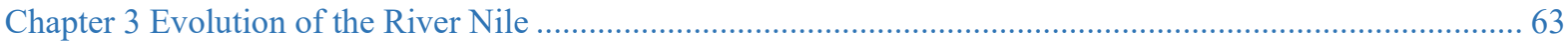

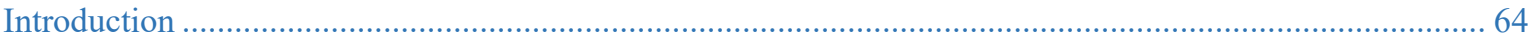

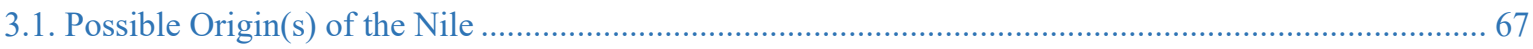

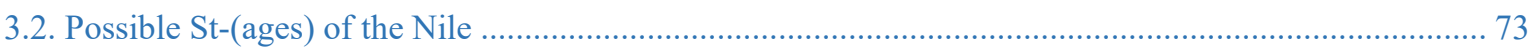

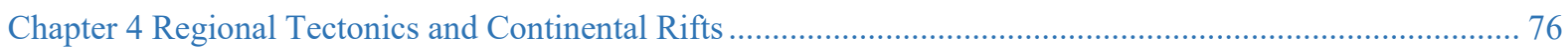

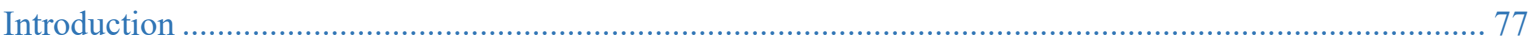

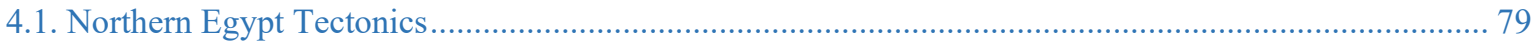

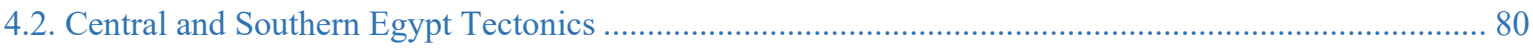




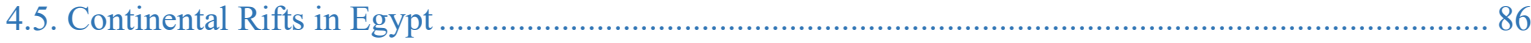

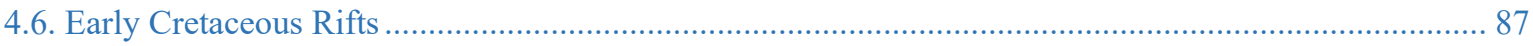

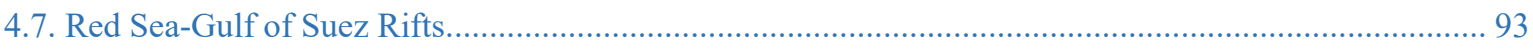

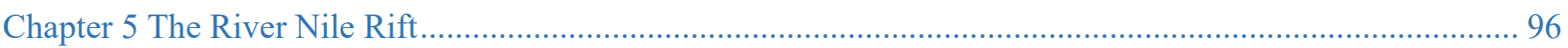

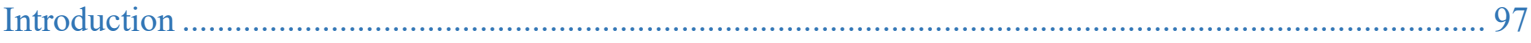

5.1. The Late Paleogene-Early Neogene Nile Rifting ..................................................................... 98

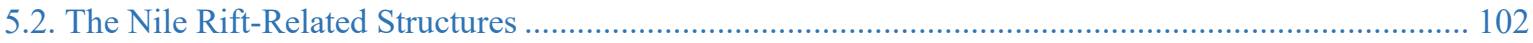

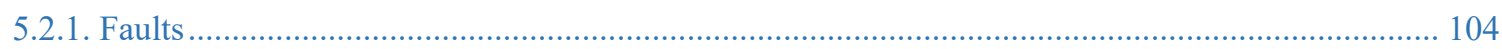

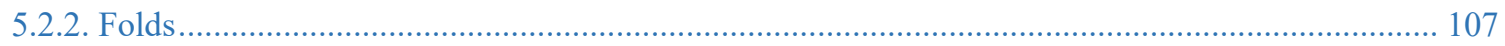

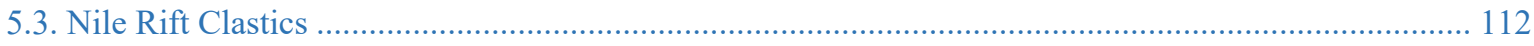

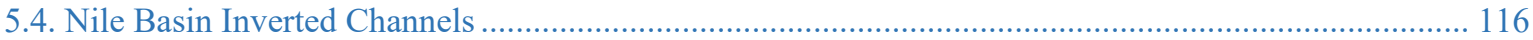

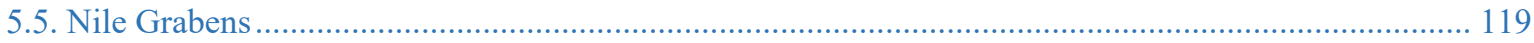

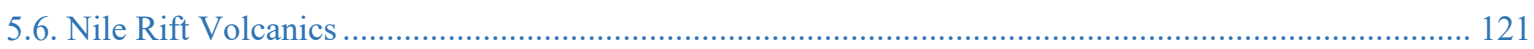

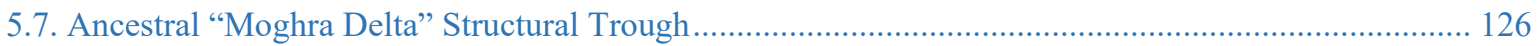

Chapter 6 River Nile Rift Segmentation and Termination ................................................................ 127

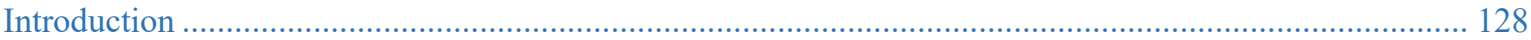

6.1. Southern Rift Segment................................................................................................................ 130

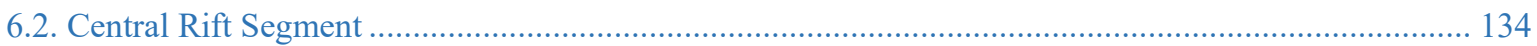

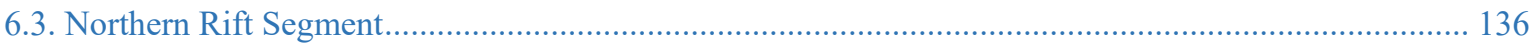

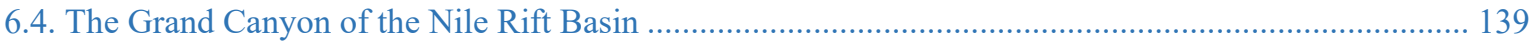

6.5. The Nile Rift Propagation and Termination ......................................................................... 142

6.6. The River Nile-Gulf of Suez Rifts ........................................................................................... 148

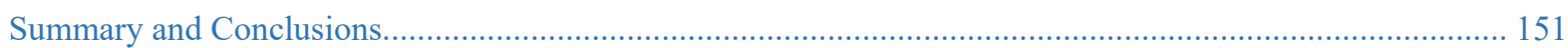

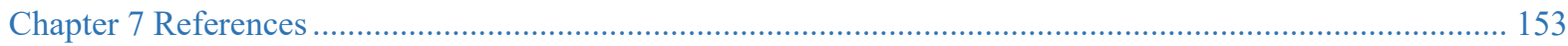




\section{List of Figures}

Fig. 1.1. Topographic map of Egypt showing the drainage basin of the River Nile and the main localities of the study area.

Fig. 1.2. Digital Elevation Model of the main African drainage basins. It particularly shows the drainage system and geomorphological units of the River Nile basin in Eastern Africa

Fig. 1.3. Hill-shaded Digital Elevation Model (DEM) with elevation-levels density slices showing the main morphotectonic units of the Nile System in Egypt. The highs and ridges are labelled in white color, while the depressions, basins and structural grabens are labelled in black.

Fig. 1.4. a) Landsat satellite image (bands 752 RGB) of the Nile Valley. b) Digital Terrain Model (DTM) indicates the physiography and structural lineaments of the Nile System (the inset rose diagram shows the NW to NNW predominant trends of the Nile's structural lineaments). c) The Nile basin(s) and their drainage systems (the inset rose diagram shows the main trends of the Nile's drainage; NW, NNW, N-S and NE)....

Fig. 1.5. Geologic map of Egypt compiled and modified from different sources cited in the reference list. The stratigraphic units were compiled and modified mainly from Klitzsch et al. (1987). The inset rose diagram shows the strike orientations of the surface structural lineaments and Precambrian Basement tectonic fabrics with dominant NW, NNW and NNE trends.

Fig. 1.6. General stratigraphy of the Nile Valley area. The stratigraphic units were modified and compiled from Said (1962), (1990b); Klitzsch et al. (1987). Thicknesses are approximated.

Fig. 1.7. Stratigraphy and field occurrences of the Eocene and Oligocene outcrops along the central and northern shoulders of the Nile Valley. a) The well-bedded Limestones of the Lower Eocene Thebes Formation, east of Assiut. b) Lower Eocene Drunka carbonates along the northern shoulders of Wadi Assiuty, west of the Nile. c) Middle Eocene Minia carbonates in the footwalls of NW-striking faults to the east of the Nile. d) Lower Eocene Drunka massive limestones exposed along E-W-oriented faults, west of Sohag. e) Upper Eocene sediments of the Fayium depression in the footwalls of Moghra depression that hosts syn-rift Oligocene gravels. f) The characteristic Oyster beds of the Upper Eocene marls of Qasr El-Sagha Formation, west of Fayium. g) The cherty carbonates of Drunka Formation overlain unconformably by the Oligocene gravels of Katkut Formation to the west of Sohag. h) Channel incisions of the Oligocene clastics along fractures and faults within the Lower Eocene Drunka massive carbonates.

Fig. 2.1. Three-dimensional (3D) perspective views of the western shoulder of the Nile Valley. a) The Nile rift grabens and their bounding NNW-striking faults. b) Landsat-8 Principal components 1, 3, 5 RGB image. c) Geologic map of the syn-rift Oligocene gravels filling the structural grabens formed in the Lower Eocene carbonates of the western Nile, west Sohag. 
Fig. 2.2. Geologic map of the central Nile Valley draped on Hill-shade DEM showing the distribution of the early syn-rift Oligocene fluvial clastics (red-sandstone beds and conglomerates) in structural grabens and troughs within the Lower-Middle Eocene carbonates. The stratigraphic units are modified from Klitzsch et al. (1987).......... 35

Fig. 2.3. Regional Hillshade relief map derived from DEM showing the major structural elements and morphotectonic units of central and eastern Egypt; the River Nile and Red Sea-Gulf of Suez Rift Systems...... 37

Fig. 2.4. False Color Composite RGB images using Landsat-8, Sentinel-2 and ASTER bands. a) Landsat- 8 bands 7, 5, and 1 in RGB. b) Sentinel-2 bands 11, 8, and 2 in RGB. c) ASTER bands 1, 2, and 5 in RGB. d) ASTER bands 8, 3, and 4 in RGB. These RGB False Color Composite images help to discriminate between the pre-rift Lower-Middle Eocene carbonates, the syn-rift Oligocene-Miocene gravels and conglomerates, rift-related basalt volcanic occurrences and the Post-rift Pliocene-Quaternary clastics and fluvial sediments. 41

Fig. 2.5. (3D) perspective views of East Beni Suef basin. a) DEM of Beni Suef fault blocks, notice that the resolution is not quite enough to characterize the inverted topographies (channels). b) RGB image of the Landsat8 band ratios 5/4, 3/1, 7/5. c) DEM of the northern part of East Beni Suef basin. d) RGB image of the Landsat-8 band ratios $7 / 2,6 / 1,2 / 3$. These band ratios in figures $b$ \& $d$ are used here to characterize the early syn-rift Oligocene gravels (in red colours) of the Nile basins and grabens, such as East Beni Suef in this example. The yellowish-greenish colours represent Middle Eocene Carbonates.

Fig. 2.6. (3D) perspective views of Western Sohag Grabens. a) Sentinel-2 FCC image of bands 11,8 ,2 in RGB, which doesn't help to characterize the structural elements as well as the different rock units in this area. b) RGB image of the ASTER PCs 3, 5 ,1. c) RGB image of the Landsat-8 PCs 7, 4, 3; with interpretational of the main grabens-bounding extensional faults of NNW trends. Integration of these PC images was very effective to reveal the Oligocene inverted channels that filled the early-formed rift grabens with syn-rift fluvial gravels, conglomerates and sandstones (red colours). This was also useful to recognize the rift-related faults west of Sohag. d) A modified geological map of the Western Sohag Grabens.

Fig. 2.7. Different terrain models extracted from DEM data of different resolutions. a) Slope model for the centralnorthern Nile showing the mega shears and fractures. It also indicates the spatial distribution of the rift-related basalt volcanic occurrences of the Nile and Gulf of Suez Rift Systems as well as the sampling sites of the Nile volcanics used in this study (white dots). b) Multi-directional greyscale Hillshade model with the controlling structural lineaments of the central Nile. The inset rose-diagram show the main trends of the structural lineaments of the Central Nile. c) Tinted Hillshade model showing the main structures and tectonic elements of the Southern Nile rift basins with simple structural interpretation of the rift-bounding extensional faults.

Fig. 2.8. Extracted structural lineament of the River Nile and Gulf of Suez-Red Sea Rift Systems. The inset rose diagrams show the strike orientations of the surface structural lineaments and Precambrian Basement tectonic fabrics with dominant NW, NNW and NNE trends. b) Extracted lineaments of the southern Nile rift segment using traditional Hillshade model with sun angle perpendicular to the predominant NW orientation (see the inset rose diagram). c) Extracted lineaments using multidirectional Hillshade model that helps to recognize the different 
structural trends of the same area such as the N-S and NE strike orientations (see the inset rose diagram). The red, green and blue colors of figures b \& c show high, intermediate and low densities of the extracted lineaments, respectively. The eastern shoulders of the southern Nile rift segment are characterized by relatively higher densities of the extracted lineaments. 51

Fig. 2.9. The major drainage basins of Egypt. a) Three main drainage basins: the Nile, South and North Western Desert basins. This is in addition to the minor basins along the borders and coastal stretches. The River Nile basin composes of two main drainage systems; the northern drainage basin between Cairo and Qena (b), which comprises the central and northern Nile rift segments as well as the major depression of Moghra. The southern drainage basin between Qena and Aswan (c), which includes the southern Nile rift segments (c). The small arrows indicate the regional flow directions of the Paleo- and present-day tributaries of the Nile drainage basins. 53

Fig. 2.10. Location map for the 2D and 3D seismic and gravity data used in this study. a) Locations of Assiut and Beni Suef basins. It also shows the locations of 26 basalt samples were collected for age-dating (white circles). b) 3D seismic surveys in Beni Suef basin. c) 2D seismic survey in Assiut basin (Wadi Mahareith concession).... 56

Fig. 2.11. SEEBASE shaded basement relief map of Egypt showing the main rift basins of Egypt. Three main groups of these rift basins are: 1) North Western Desert Jurassic and Cretaceous basins with E-W, ENE and NE orientations. 2) Cretaceous and Late Paleogene-Early Neogene Nile rift basins such as, from south to north, Kharit, Nuqra, KomOmbo, Central Nile, Assiut and Beni Suef basins; all are of NW to NNW orientation. 3) NNWoriented Red Sea-Gulf of Suez Oligocene Rift System in the east. The main structural belts and shear zones are shown in black lines. Data from Steffan et al. (2000). 58

Fig. 2.12. Regional gravity models over Egypt using data from WGM2012 (Bonvalot et al., 2012). a) Free-Air gravity anomalies reduced by the topographic effect. b) Bouguer gravity anomalies. c) Isostatic gravity anomalies. The three models show clear negative gravity anomalies beneath and around the proposed southern, central and northern rift segments along the River Nile (white-dotted ellipses) as well as the rift-oblique and rift-orthogonal transfer zones such as the prominent basement high of the Qena-bend zone, and the northern termination belt between Bahariya and Cairo (Bahariya-Fayium belt), both are characterized by conspicuous positive gravity anomalies (red-dotted ellipses). d) Geoid anomaly model showing the regional negative anomaly model along the River Nile, data from Hirt et al. (2013).

Fig. 2.13. Magnetic anomaly over Egypt showing the structural morphology of the Precambrian Basement, the major tectonic fabrics and distribution of the sedimentary rift basins. It indicates the regional distribution, geometry and architecture of sedimentary rift basins along the River Nile (e.g. Kharit, Nuqra, KomOmbo, Assiut, wadi Assiuty, Beni Suef and Moghra depression) in addition to the North Western Desert NE-trending basins. These rift basins show conspicuous negative anomalies due to the thick accumulation of sediments as well as the thinned crust and deep Basement levels. While, on the other hand, the raised rift shoulders and uplifted Basement regions show-striking positive anomalies. Examples are the Basement highs of the southern Nile rift shoulders, 
Sin El-Kadab Plateau, Qena bend transfer zone, Sohag High, and the NE-oriented rift-termination belt of the Bahariya-Fayium fold-fault structures and Kattaniya Highs. Data from EMAG2v3 (Meyer et al., 2017).

Fig. 3.1. Tinted Hillshade DEM of the River Nile's major drainage basin in Africa. It shows the main tributaries and branches that feed the mainstem of the river through its drainage basin with N-S and NNW regional flow directions. It also indicates the main southern sources of the Nile in the highlands of the Ethiopian and Central Lake Plateaus. The inset map shows the main African drainage basins.

Fig. 3.2. The Nile's drainage basin in Egypt shown on tinted Hillshade DEM. This map displays the robust structural control of the intracontinental rift basins such as Kharit, Nuqra, KomOmbo and Beni Suef, and their bounding faults on the geometry and development of the River Nile basin, its drainage systems and the main depressions and grabens, which received the early syn-rift clastic of the proposed Late Oligocene rift, e.g. the grabens of Sohag, Assiut, Minia and Moghra.

Fig. 3.3. Seismic time slice on the top of the Campanian sediments showing the incision of the Ancestral Eonile Canyon in The Early Cretaceous Beni Suef Basin. The lower seismic profile shows the deep incision of the Ancestral River along deep-seated faults with successive and severe erosion of the underlying Eocene and Upper Cretaceous sediments. The inside valley was filled successively with Late Miocene-Pliocene shallow marine and fluviatile sediments, and Quaternary wadi clastics and fanglomerates.

Fig. 3.4. Extensional faults, cliffs and fault blocks along the shoulders of the Nile Valley. a) E-W-oriented faults along Wadi Assiuty cliffs and titled Lower Eocene Thebes Limestones, east of the Nile, Assiut. b) NW-striking faults forming grabens that were filled with Pliocene sediments along the western shoulders of the Nile Valley, Assiut-Sohag district. c) Rotated and tilted Lower Eocene (Drunka) Limestone fault blocks along NW-oriented faults that bound the eastern cliffs of the River Nile, Assiut. d) Accumulation of Syn-rifting Oligocene gravels and red sandstones in fault-bounded grabens and fractured Lower Eocene Drunka carbonates. e) Oligocene channel incisions along NNW-oriented faults and fractures parallel to the main course of the Nile. f) NW-striking fault scarp with accumulation of fluviatile Pliocene shales and siltstones. 72

Fig. 4.1. The major Mesozoic and Cenozoic rift basins in Egypt. The map shows the distribution of the NW to NNW-oriented Early Cretaceous rift basins in southern and central Egypt along the course of the River Nile, and the Red Sea-Gulf of Suez rift system. It also indicates the distribution of the E-W to NE-oriented JurassicCretaceous basins of northern Egypt, particularly the north Western Desert. The inverted basins and major uplifted fold-fault structural belts of the Late Cretaceous Syrian Arc tectonics are also highlighted. This in addition to the Late Oligocene proposed rift structures along the Nile. The locations of basins and inversion-fold structures are modified after Bosworth (2015). Notice the distribution of rift-related Cretaceous and Tertiary volcanics across the rift basins and shoulders, modified after Klitzsch et al. (1987).

Fig. 4.2. Seismic section in the north Western Desert showing one of the major Jurassic half-graben rift basins that were inverted during the Late Cretaceous Syrian Arc tectonics, after Dolson et al. (2014). 79 
Fig. 4.3. Interpreted (SW-NE) seismic section in the Early Cretaceous KomOmbo rift basin in southern Egypt. After Dolson et al. (2014), data courtesy of Dana Gas Egypt. For the stratigraphic units, please see Fig. 1.6... 81

Fig. 4.4. SEEBASE map showing the Cretaceous rift basins of the North Western Desert and Nile Valley. It displays the major influence of the mega-shear zones and tectonic fabrics of the Precambrian Basement on the evolution and geometry of the NE-, NW- and NNW-oriented rift basins along the Nile. The numbers 1, 2 and 3 indicate the three main Nile rift segments that are considered in this study as southern, central and northern, respectively. Data from Steffan et al. (2000).

Fig. 4.5. The structural architecture and segmentation of the Late Oligocene Gulf of Suez rift basin. Compiled from McClay et al. (1998), Bosworth and McClay (2001), Abdelkhalek (2014).

Fig. 4.6. The Late Oligocene rift-related red beds and basalt flows, western onshore of the Gulf of Suez. a) Thick basalt flows overlaying the early-syn rift Oligocene red beds and clastics. b) The effect of the basalt flows on the Oligocene red beds and clastics. c) Thick succession of Oligocene (syn-rift) fluviatile coarse clastics, conglomerates and cross-bedded red sandstones.

Fig. 4.7. Early Cretaceous Beni Suef Basin, Northern Nile. NE-SW seismic section across the NW-oriented Early Cretaceous Beni Suef Basin. Notice the Deep incision of the Eonile canyon (Ancestral Nile) through the Eocene and Upper Cretaceous rocks. The lower figure represents an isopach map of the Lower Cretaceous (Albian) synrift sediments of Kharita Formation. The evolution of both the Beni Suef and younger Nile Valley basins were controlled by NW- to NNW-striking faults as observed in the seismic section and on the lower isopach map. . 90

Fig. 4.8. Early Cretaceous Assiut Basin, Central Nile. a) The map represents the measurement of the overall card surveillance gravity field. It shows the geometry and distribution of the NW-oriented basins along the central Nile Valley, the Early Cretaceous Assiut Basin, in addition to the EW and ENE-trending cross elements. b) depth-tobasement map based on gravity interpretation showing the structural architecture of Assiut basin and the geometry of the rift-bounding faults. c) Seismic section across Assiut basin showing the prominent thickening of the early syn-rift sediments of the Lower Cretaceous (Albian) Kharita Formation. The faults were reactivated during the latter phase of extension accompanied the Late Paleogene-Early Neogene rifting along the River Nile System.92

Fig. 4.9. River Nile-Gulf of Suez rift-related volcanism, the Qattamiya Mountain, Eastern Nile, western Gulf of Suez. a) Basalt fissure eruptions and flows along NW-oriented faults cutting through upper Eocene and Oligocene sediments. b) Highly fractured Basalt along NW-striking fault zone. c) Strongly deformed upper Eocene sediments as a result of the rift-related extension and basalt intrusion. The age of Basalt in this locality is $\sim 21.5$ Ma, according to ${ }^{40} \mathrm{Ar} /{ }^{39} \mathrm{Ar}$ rage-dating of Bosworth et al. (2015b).

Fig. 4.10. The River Nile rift-related Volcanism, Western Nile, SW Fayium-Beni Suef. NW-oriented basalt dikes along faults of en-échelon pattern arrangement. b) Basalt rocks overlying the upper Eocene sediments of Qasr ElSagha Formation. c) Columnar jointing of basaltic cinder cone. The age of basalt in this locality according to 
Fig. 4.11. The River Nile rift-related Volcanism, Western Nile, Bahnasa. Basalt eruptions along NW-oriented faults (a). Brittle-ductile deformation of the M. Eocene carbonates and marls with slickenlines showing normal dip-slip movement along the faults. The age of basalt in this locality according to K/Ar age-dating of the present work is $\sim 22 \mathrm{Ma}$, see Table 1; Sample (BHN-W-1).

Fig. 5.1. Structural map of the northeastern sector of the Nile Rift System, the western area between Assiut and Minia. The map shows the prevailing NNW- and NW-striking extensional faults that bound linear narrow grabens.

Fig. 5.2. Field occurrences of rift-related structures along the Nile Rift System. a) NW-striking extensional fault cutting through Middle Eocene rocks of the Thebes Formation, west Assiut. b) E-W oriented fault scarp in Wadi Assiuty, showing the orthogonal NW-striking faults with slickenlines indicating an oblique-slip displacement. c) Rift-parallel (NW) and rift-orthogonal (ENE) normal faults with rotated-fault blocks along the eastern shoulders of the Nile Valley, east Minia. d) A vertical plane of NNW-striking extensional fault with normal dip-slip kinematic indicators. d) Strongly fractured Lower Eocene Drunka limestones with NW to NNW dominant strike orientations. e) Subsidiary fractures of multiple orientations reflecting the possible radial extension of an earlyrifting phase. f) En-échelon fault arrangement of NNW-oriented extensional faults with rely-ramps in-betweens.

Fig. 5.3. Nile Rift-related volcanism, Samalut Mountain, eastern Nile, west Minia. a) Basalt fissure eruptions and flows along NW-oriented faults cutting through Middle Eocene rocks. b) Fractured Basalts along NW-striking fault zone. c) Strongly deformed Middle Eocene marls and carbonates sediments as a result of the rift-related extension and basalt eruptions, notice the brittle-ductile syn-rift deformations and drag-folding in the pre-rift Middle Eocene marls and shales. d) Basalt inclusions along the fault damage-zone within the Middle Eocene marls. The age of basalt in this locality according to $\mathrm{K} / \mathrm{Ar}$ age-dating of the present work is $\sim 20.4 \mathrm{Ma}$, see Table 1; sample SMS-2.

Fig. 5.4. Structural map of the western sector of the Nile Rift System, the western area between Sohag and Assiut. The map shows the prevailing NNW- and NW-striking fractures and extensional faults forming shallow grabens that host the earl syn-rift Oligocene gravels and extensional fault-related folds. Interference of the two fault trends form characteristic polygonal- shaped graben and horst fault blocks. 106

Fig. 5.5. Structural map of the western sector of the Nile Rift System, the western area between Assiut and Minia. The map shows the prevailing rift-parallel trends, NNW- and NW, of the extensional faults and related folding (hundreds of anticlines and synclines of blue color). The Middle Eocene rocks of Minia Formation host the majority of these rift-related folds as a good indicator for the role of mechanical stratigraphy and different rheology of rocks on their brittle-ductile deformation. The Minia limestones are relatively less competent than the cherty hard-carbonates of the southern Lower Eocene Drunka Formation. 108

Fig. 5.6. Structural map of the western sector of the Nile Rift, the western area of Moghra Graben. It shows the strongly deformed shoulders of the Moghra with dominant NNW- to NW-striking fractures, extensional faults 
and related folding. The change of the density and predominant orientation of the extensional faults show a clear influence on the geometry and distribution of the associated folds, which display a heterogeneity between both the rift-parallel and rift-orthogonal trends, i.e. NW and NE trends, respectively.

Fig. 5.7. Field Occurrences of the Nile Rift-related folding. a) NW-oriented syncline in Middle Eocene Minia carbonates. b) Faulted syncline (with fault-parallel axial trace) showing that the folding postdated or was contemporaneous with the development of the extensional faults during the Nile rifting. c) NE-trending Anticline in Lower Eocene Drunka limestones bounded by NW-striking extensional fault (with fault-orthogonal axial trace). d) Forced NW-oriented anticline formed by the uplift of the basalt intrusion along NW-striking dikes. e) Syncline with fault-oblique axial trace in Middle Eocene Samalut limestones. f) Folding formed by horizontal movements along NE-striking dextral strike-slip faults, north to Wadi Assiuty Shear Zone. g) Elongated NW-oriented Anticline along the western shoulders of the Moghra Graben. 110

Fig. 5.8. Filed Occurrences of the Nile syn-rift Oligocene clastics. a) Example of the NW-oriented grabens, west of Sohag, which hosts the earliest syn-rift Oligocene clastics (Katkut Formation, equivalent to Gebel Ahmar and Qatrani formations to the north of the River Nile Rift System. b) Well-rounded gravels of the Katkut Formation. c) Imprecations of the Oligocene Katkut gravels that indicate a possible NNW to NW (rift-parallel) Paleo-flow directions of the old rivers. d) Oligocene fluviatile red sandstones and conglomerate beds, southwest of Sohag. e) Roots and plant remain of the syn-rift fluviatile sandstones. f) Tilted Oligocene sandstone and conglomerate beds along NW-striking normal fault, which indicates the syn-depositional extension of the early-formed rift basins.

Fig. 5.9. The outcrop geology of Gebel Qatrani, northwestern Nile Rift System, west Fayium. a) Panoramic view of the basalt sheets overlying the Oligocene clastics of Qatrani Formation. b) Channel sandstone and siltstone beds with occurrences of palaeosols and tidal/estuarine facies and red beds (d). c) Rift-related basaltic flows unconformably overlying the earliest syn-rift fluviatile clastics of the Oligocene Qatrani Formation. The age of basalt in this locality according to K/Ar age-dating of the present work is $\sim \mathbf{2 4} \mathrm{Ma}$; see Table 1, Sample (QT3).

Fig. 5.10. Conceptual model for the development of the Oligocene inverted channels along the faulted-shoulders of the River Nile Rift System

Fig. 5.11. The inverted Oligocene gravel-filled channels of the River Nile Rift System. Locations are shown in the map (d). Most of the channels have a rift-orthogonal paleo flow direction i.e. NE trend. a) Digital elevation model showing one of the longest inverted channels in the western shoulder of the Nile Basin, the western area between Assiut and Minia, west of the Moghra basin. b) Inverted Oligocene channel system flowing in the Beni Suef basin, northeast of the Nile, west Beni Suef. c) The inverted channels that filled early-formed syn-rift grabens of the Nile, west Sohag. d) Possible flow directions (black arrows) of the Oligocene paleo-rivers and channels of the Nile Rift. 118 
Fig. 5.17. The River Nile Rift Grabens, West of Sohag. Notice the similarity between the architecture and geometry of the syn-rift gravels-filled grabens and the course of the Pliocene to Quaternary Nile Valley

Fig. 5.18. (3D) views of the early-formed "juvenile" grabens that were filled with syn-rift Oligocene clastics. a) DEM surface of the longitudinal narrow grabens on the western shoulders of the Nile showing the interactions between both rift-parallel (NW- \& NNW-striking) and rift-orthogonal (E-W \& NE-striking) faults that shaped the grabens (c). b) The processed Sentinel-2 image (PCs 5, 3, 2) used to discriminate the Oligocene gravels filling the rift grabens (see Chapter 2). c) Structural model for the Oligocene juvenile grabens along the western shoulders of the central Nile rift segment, west Sohag.

Fig. 5.19. Zig-zag linked fault pattern of the rift-parallel and rift-orthogonal (dextral strike-slip cross elements) that controlled the development of the western Nile grabens and early syn-rift fluvial sedimentation of the Oligocene clastics unconformably on the pre-rift Eocene strata. It shows the structural control of the early rift structures on the successive incisions of the ancestral Nile river(s) and channels.

Fig. 5.12. Basalt dike occurrences, northwest Beni Suef, west Nile. a) En echelon pattern of NW-oriented basalt dikes and hills. b) Collapsed basalt cinder cone overlying oyster beds of the Upper Eocene Qasr El-Sagha Formation. c) Columnar joints of the sag-walls of the basalt hill. The age of basalt in this locality according to K/Ar age-dating of the present work is $21 \mathrm{Ma}$, see Table 1; Sample (QZ-1).

Fig. 5.13. Basalt sill occurrences, Gebel Samalut, east Minia, east Nile. a) Panoramic view of basalt sill intruded the pre-rift Middle Eocene carbonates of Samalut Formation. The limestones and marls of the Samalut Formation show extensive ductile deformation, flow and piercement structures as a result of the syn-rift basalt intrusions (b \& c). d) Basalt inclusions in the Middle Eocene carbonates. The age of basalt in this locality according to the K/Ar age-dating of the present work is 20.5 Ma; see Table 1, Sample (SMS-2).

Fig. 5.14. Basalt columnar joints of variable geometries, east Minia, east Nile Valley (a). The multiple geometries of the columnar joints as well as the different structural settings and lithological characteristics of the basalt outcrops might imply successive "short-lived "syn-rifting phases of volcanism (b \& c). Basalt fissure eruption with a characteristic plumose structure (d). The age of basalt in this locality according to K/Ar age-dating of the present work differs between $\sim 29.5,31.6$ and 33.2 Ma. This indicates multiple eruptions of the Nile Rift-related basaltic volcanism during the Late Oligocene; see Table 1; Samples (SMN, SMT\& SMB), respectively.

Fig. 5.15. Forced folding of Gebel Gebeil Anticline. NW-oriented anticline within the Lower Eocene carbonates of Thebes and Drunka formations of G. Gebeil, west Assiut (the upper field photo). The folds were formed as a result of a local uplift accompanied the syn-rift basaltic intrusions (core of the anticline), however, the area was dominated by extensional deformation that developed numerous fault-bounded grabens that hosted the early synrift clastics (the lower 3D view). The age of basalt in this locality according to K/Ar age-dating of the present work is $\sim 28$ Ma, see Table 1; Sample (GG-1). 124 
Fig. 5.16. Distribution of the Late Oligocene-Early Miocene Nile and Gulf of Suez rift-related basalts (red). The small multi-colored dots show the locations of 26 basalt samples collected along the shoulders of the Nile Rift System. The green asterisks (*) represent the localities of 14 samples that were chosen for whole-rock K/Ar agedating (seeTable 1).

Fig. 6.1. General structural model of the proposed River Nile Rift System in the area between Aswan-Kharit and Cairo. The boundaries of the three main rift segments are outlined by red-dotted squares in the lower map and numbered as 1, 2 and 3 (southern, central and northern, respectively). The inset rose diagram shows the dominant trends of the rift bounding faults and cross elements along the Nile Valley.

Fig. 6.2. Structural model of the Southern Nile Rift Segment. This includes the three main Early Cretaceous rift basins of the southern Nile Valley, Kharit, Nuqra and KomOmbo. The eastern shoulders of the Nuqra graben (rely area) host the Cretaceous syn-rift Natash volcanics ( $\sim 100 \mathrm{Ma})$. The inset rose diagram shows the dominant trends of the rift structures.

Fig. 6.3. (3D) views of the drainage basin in the Southern Nile Rift Segment. a) DEM shows the main drainage basin of the southern Nile. b) 3D geologic model showing the evolution of the Nile's drainage system on the reactivated Cretaceous rift basins of the southern segment.

Fig. 6.4. Structural model of the Central Nile Rift Segment. This includes the Oligocene rift grabens/half-grabens of the west-central shoulders of the Nile basin as well as the Cretaceous NW-striking faults and E-W to NEtrending shears of Assiut basin and wadi Assiuty, further north. 135

Fig. 6.5. Structural model of the Northern Nile Rift Segment. This hosts the Oligocene NNW-oriented grabens of Minia basin, and the NW-oriented Early Cretaceous Beni Suef basin and its bounding faults, which were reactivated during the Late Oligocene Nile rifting. The western extents comprise the Moghra graben and most of the rift-related basalt dikes and flows ( 25-23 Ma, this work). The inset rose diagram shows the dominant trends of the rift structures and basalt dikes......

Fig. 6.6. Field occurrences of the extensional faults that controlled Oligoene sedimentation of the Central and Northern Nile Rift Segments. a) NNW-striking faults west of the Nile extending for kilometers with minor amounts of vertical throws. b) Rift-orthogonal dextral E-W oriented oblique-slip fault bounds the southern extents of the central rift segment. c) Linked-fault pattern of rift-parallel and rift-orthogonal elements in the Minia grabens, northern rift segment. d) Major ENE-striking dextral fault bounding the northern margins of the Moghra basin, notice the folding formed in the footwalls of the fault. e) Panoramic view for one of the syn-rift juvenile grabens/basins west of the northern segment, near Minia. It hosts fault-bounded channel incisions filled with synrift Oligocene gravels overlying unconformably strongly deformed marls and carbonates of the Middle Eocene Minia Formation (f). g) Fault zone forming the boundary between the syn- (Oligocene gravels) and pre-rift sediments (M. Eocene marls). h) Structurally-controlled channel incision, west Assiut. 138 
Fig. 6.7. The Grand Canyon of the River Nile Rift System. a) DEM of the northern part of the Nile Canyon in the area between Beni Suef basin and Fayium depression. b) NW-SE seismic profile crossing the Nile Canyon and showing the deep incision and severe erosion of the Ancestral Eonile into the thick Cretaceous and Eocene rock sequences of Beni Suef basin. It demonstrates the structural control and influence of extensional faults on the incision of the Nile Rift Canyon.

Fig. 6.8. Interpretation of 3D Seismic data of West Beni Suef Basin. a) Depth to base Nile Canyon map based on interpretation of 3D seismic showing the geometry and architecture of the deep incision of the Canyon. b) Seismic attribute time slice on the Upper Cretaceous level of Beni Suef basin. It indicates the narrow and deep downcutting of the early formed Eonile Canyon through the underlying strata.

Fig. 6.9. The Fayium structural termination belt of the River Nile Rift System. Detailed structural mapping of the Fayium hybrid-structural zone with major occurrences of rift-oblique and rift-orthogonal faults, folds and shear zones (of ENE \& NE trends) that strongly influenced the further northward propagation of the rift-parallel extensional faults (of NNW \& NW trends). The oblique structures were probably formed during the Late Cretaceous dextral-transpression of the Syrian Arc wrench tectonics that were reactivated during the Late Paleogene-Early Neogene, and strongly controlled the segmentation and termination of the younger structures along the Nile.

Fig. 6.10. The development and termination of the River Nile Rift System. a) 3D view showing the development of the drainage basin of the River Nile along the NW to NNW-trending Late Paleogene-Early Neogene Rift system. b) ENE to NE-oriented fold-fault structural belt that extends between Bahariya and Fayium to the north of the Nile rift. The highly oblique faults, folds and shear zones of this major structural belt terminated the further northward propagation of the proposed rift.

Fig. 6.11. Tectonostratigraphy of the Nile Valley area. The lift figure shows schematic structures that „roughly” summarizes the tectonic evolution of the Cretaceous and Late Oligocene rift basins along the Nile Valley and their influence on the development of the Nile's drainage systems and basins. The stratigraphic units were modified and compiled from Said (1962), (1990b); Klitzsch et al. (1987). Thicknesses are approximated.

Fig. 6.12. The Late Paleogene-Early Neogene Rift Systems of the River Nile and Gulf of Suez. a) Structural architecture and segmentation of the embryonic "short-lived" rift system proposed in this study along the River Nile. It shows the spatial distribution of the rift structures and volcanics. b) Structural setting of the tectonically mature Gulf of Suez rift basin (the faults were modified from previous work of the present author and different sources cited in the reference list).

Fig. 6.13. The abandoned Nile Rift and the mature Red Sea-Gulf of Suez rift basins. It shows the evolution of the Nile's drainage basin along the proposed NW- to NNW-oriented rift system along the course of the river. It indicates the spatial distribution of the rift structures, basalt volcanics and syn-to-post rift sediments. 150 


\section{List of Tables}

Table 1. The Whole-rock K/Ar age data of 14 basalt samples in the study area (River Nile rift-related volcanics; average age $\sim 25-23 \mathrm{Ma}$ ) 125

\section{Structure of the Thesis}

The thesis comprises six chapters, in addition to summary, conclusions and cited references. The chapters present the main work of four manuscripts prepared for submission. The followings are short outlines of each chapter:

Chapter 1 discusses the regional geology, geography, stratigraphy, and morphotectonic features of the River Nile System in Africa, and particularly in Egypt. The previous relevant studies on the evolution of the drainage basins of the ancestral and present-day River Nile are also addressed in this chapter. It summarizes the main idea, questions and motivation of the present study.

Chapter 2 explains the properties and specifications of the different kinds of surface and subsurface datasets that were integrated here, and presents the variable methodologies, data-processing technique, and workflows used in this study. It displays some of the results and data-processing outputs.

Chapter 3 presents different hypotheses and suggestions that have been proposed on the possible tectonic/non-tectonic origins of the development of the River Nile System. It also discusses several controversial arguments and discussions on the evolutionary history of the drainage basins of the river in Africa and Egypt.

Chapter 4 discusses the regional tectonic setting, inherited tectonic fabrics, successive deformational phases, and evolutionary history of the southern, central and northern intracontinental Early Cretaceous and Late Paleogene-Neogene rift basins in Egypt, principally along the course of the Nile valley.

Chapter 5 explains the various tectonic criteria and structural setting of the proposed Late PaleoceneEarly Neogene rift along the Egyptian River Nile system. This chapter addresses several Late Oligocene Nile rift-related structures, early syn-rift sediments, and rift-related volcanism.

Chapter 6 describes the three dimensional structural and kinematic models, and tectonic evolution of the "abandoned" River Nile Rift System. It suggests possible reasons for the abandonment of the shortlived "embryonic" Nile Rift and briefly discusses a "kinematic" comparison with the well-developed and tectonically-mature Late Oligocene- Miocene Red Sea-Gulf of Suez Rift System. This chapter explains the tectonic evolution of the Nile Rifting during the Early Cretaceous and Late Oligocene.

Summary and Conclusions: summarizes the main ideas, suggestions and conclusions of the dissertation. 
Chapter 1 Introduction and General Geology 


\subsection{Introduction}

The northerly-flowing River Nile $(\mathrm{RN})$ is a prominent geological feature in Africa and particularly in Egypt (Fig. 1.1). It forms a relatively wide valley running midway through the Egyptian Desert. The Nile represents a broad continental depositional system that flows in a major drainage basin throughout central and northeast Africa, and characterized by rapid, changeable and complex evolutionary history. It has modified the physiography of a large part of central and eastern Africa (Fig. 1.2). The RN is sourced from different drainage systems that were originated independently through different geodynamic processes and tectonic settings as well as several climatic changes. The Nile is the longest river in the world with an approximate distance of $\sim 6.8 \times 10^{3} \mathrm{~km}$. It has a regional northward gentle gradient and flow, with two exceptions at the Great Nile Bend in Sudan and Qena Bend in Egypt where the river flows in SW and WSW directions, respectively (Fig. 1.1 \& Fig. 1.2).

The long northward-flowing journey of the river and its tributaries starts from the two main highs at the equatorial Great Lakes in central Africa (Lake Plateau) and the volcanic highlands of the Northwestern Ethiopian Plateau (Afar Volcanics), and discharge into its downstream in northern Egypt forming the largest delta of the Mediterranean Sea (Fig. 1.2). The RN has three major tributaries, Atbara, the White Nile and Blue Nile that merge to form the mainstem at Khartoum in northern Sudan before entering Egypt (Fig. 1.2). The main RN, its delta and the subordinate tributaries drain water in a huge basin with a total area of $\sim 3.26 \times 10^{6} \mathrm{~km}^{2}$ including tracts of eleven countries. Egypt hosts only the mainstem of the $\mathrm{RN}$ flowing in a valley that occupies an alluvial strip extending for $\sim 1600 \mathrm{~km}$, and forming the boundary between the great plateaux of the Eastern and Western Deserts (Fig. 1.2).

The Egyptian RN flows in a drainage basin of an area of $\sim 3.27 \times 10^{3} \mathrm{~km}^{2}, \sim 1 / 10$ of the River's total watershed area, but with no present-day feeding tributaries (Fig. 1.1 \& Fig. 1.3). It is the only river that carries part of the drainage of Equatorial Africa through the barren and rainless Sahara to the Mediterranean Sea, while the origin of the numerous basins that constitute the modern river is closely tied to the history of the African continent (Said, 1993) (Fig. 1.2). 


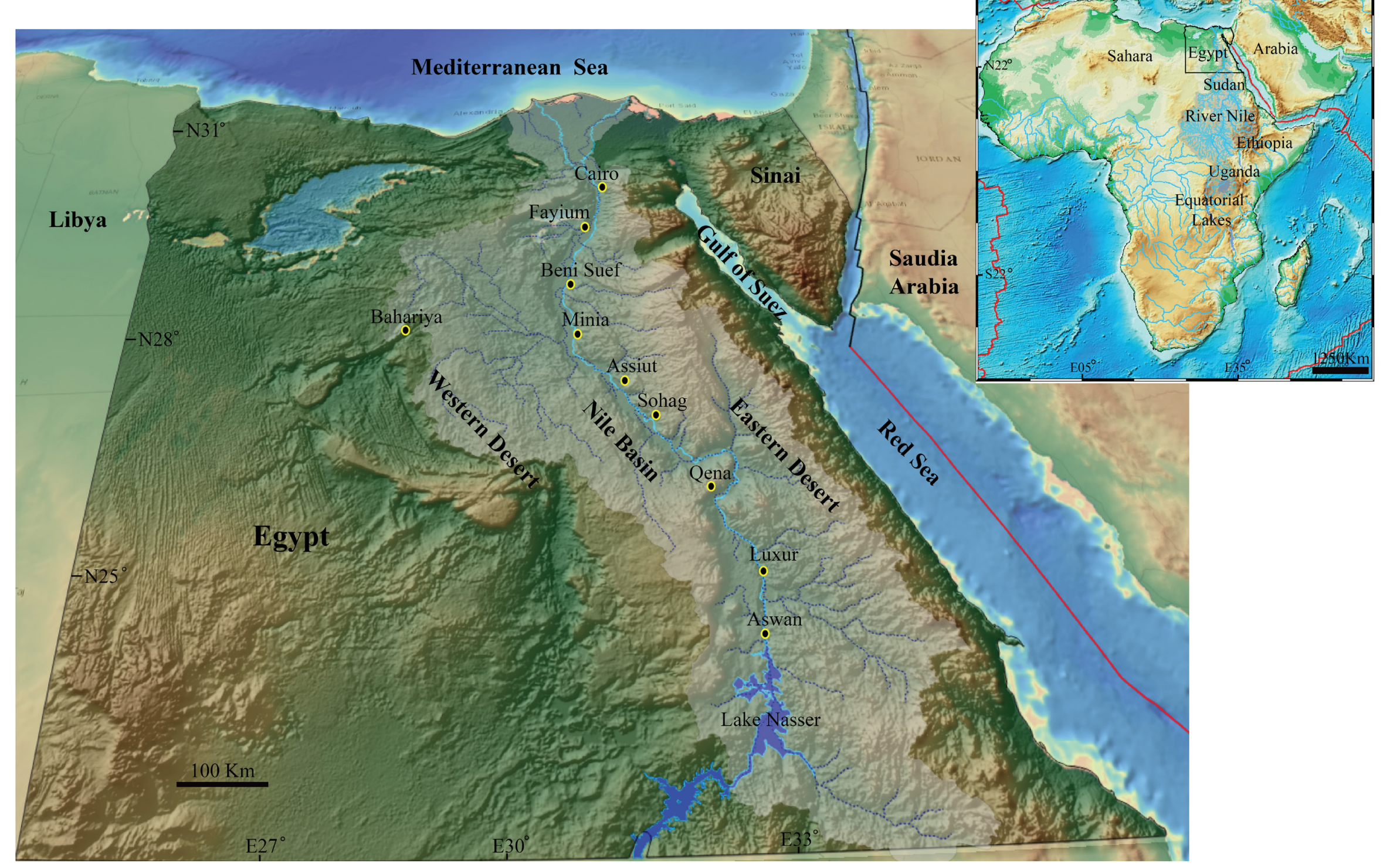

Fig. 1.1. Topographic map of Egypt showing the drainage basin of the River Nile and the main localities of the study area. 
The river flows for about $70 \%$ of its total length in an incised valley flanked by two major plateaus that are made up of hard Eocene Carbonates and Cretaceous sediments (Nubian Sandstones) (Fig. 1.4 \& Fig. 1.5). The Recent $\mathrm{RN}$ has been originally assembled and accumulated from multiple drainage basins of different evolutionary histories and tectonic settings. Each of them has been developed during a particular period in the Cenozoic time, starting probably from the Late Eocene or Oligocene to Quaternary time. The connection of the Nile drainage systems, which shaped the "present-day" pattern of the river, was seemingly much recent compared to the origin of most of them (Fig. 1.1).

Most of the river systems and their drainage basins originate at exhuming orogenic belts that form in compressional tectonic settings, and discharge to the ocean or sea to develop a delta, e.g. the Amazon River (Rzóska, 1978). An uplifted zone, which is often formed by plate collisions, and an adjoining uplifted subcontinental-scale catchment area are the requirements to exist for a time long to create and sustain the drainage system for a major river (Tandon and Sinha, 2007). Some rivers, but less common, can also be created due to rifting processes such as the Rio Grande that is considered as a major pull-apart basin developed from separate shallow sub-basins, which assembled into an integrated system in the Early Miocene time (Gupta, 2007; 2020).

The Neogene Ancestral Nile in Egypt has probably evolved along shallow rift segments and troughs of NW to NNW orientation, which was formed in the Late Eocene-Oligocene time and was probably aborted at a very early "embryonic" stage (Fig. 1.4). The failed arm (Aulacogen) at the triple junction of continental rifting may also establish long, narrow and deeply incised depressions that may develop into a river system, e.g. the Blue Nile, which was formed within the rift system of Ethiopia and flow through a deep gorge for about half of its length (Woodward et al., 2007; Gupta et al., 2020, see Fig. 1.2). It has been also proposed that the Lower Mississippi River is located above a Cretaceous subsurface rock embayment that is probably related to a reactivated rift, which might have started much earlier in the late Precambrian (Knox, 2007). Further minor and younger tectonic events usually change the framework of drainage basins and channels of many river systems over time. 
The orientations and pathways of river courses are commonly controlled by large-scale intracontinental structures such as faults, fractures and folds. The $\mathrm{RN}$, as an example, is structurally controlled with several Precambrian basement mega-shear zones, fractures, faultfold belts and topographic swells influencing the orientation of its course (Abdelsalam, 2018).

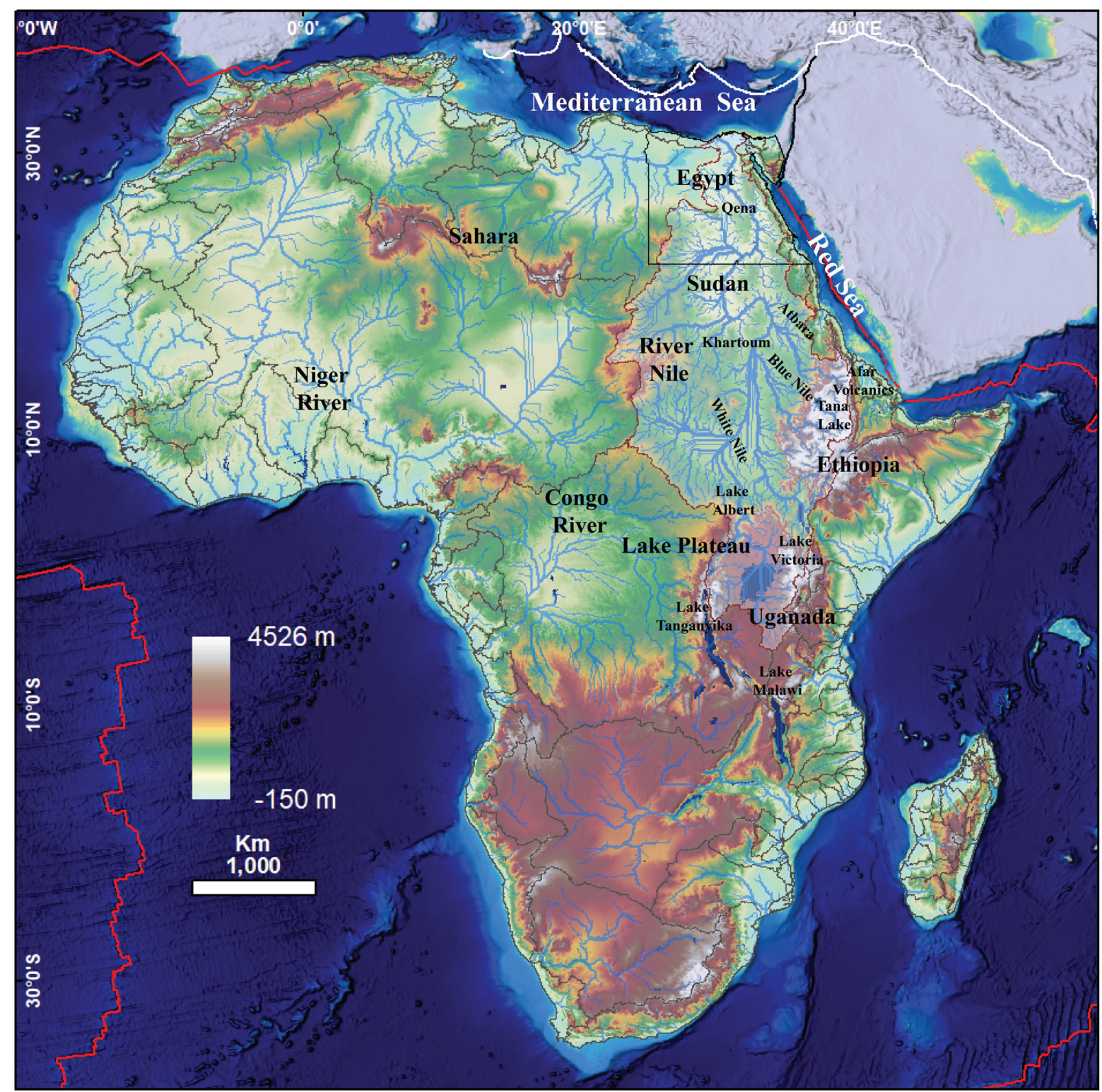

Fig. 1.2. Digital Elevation Model of the main African drainage basins. It particularly shows the drainage system and geomorphological units of the River Nile basin in Eastern Africa. 


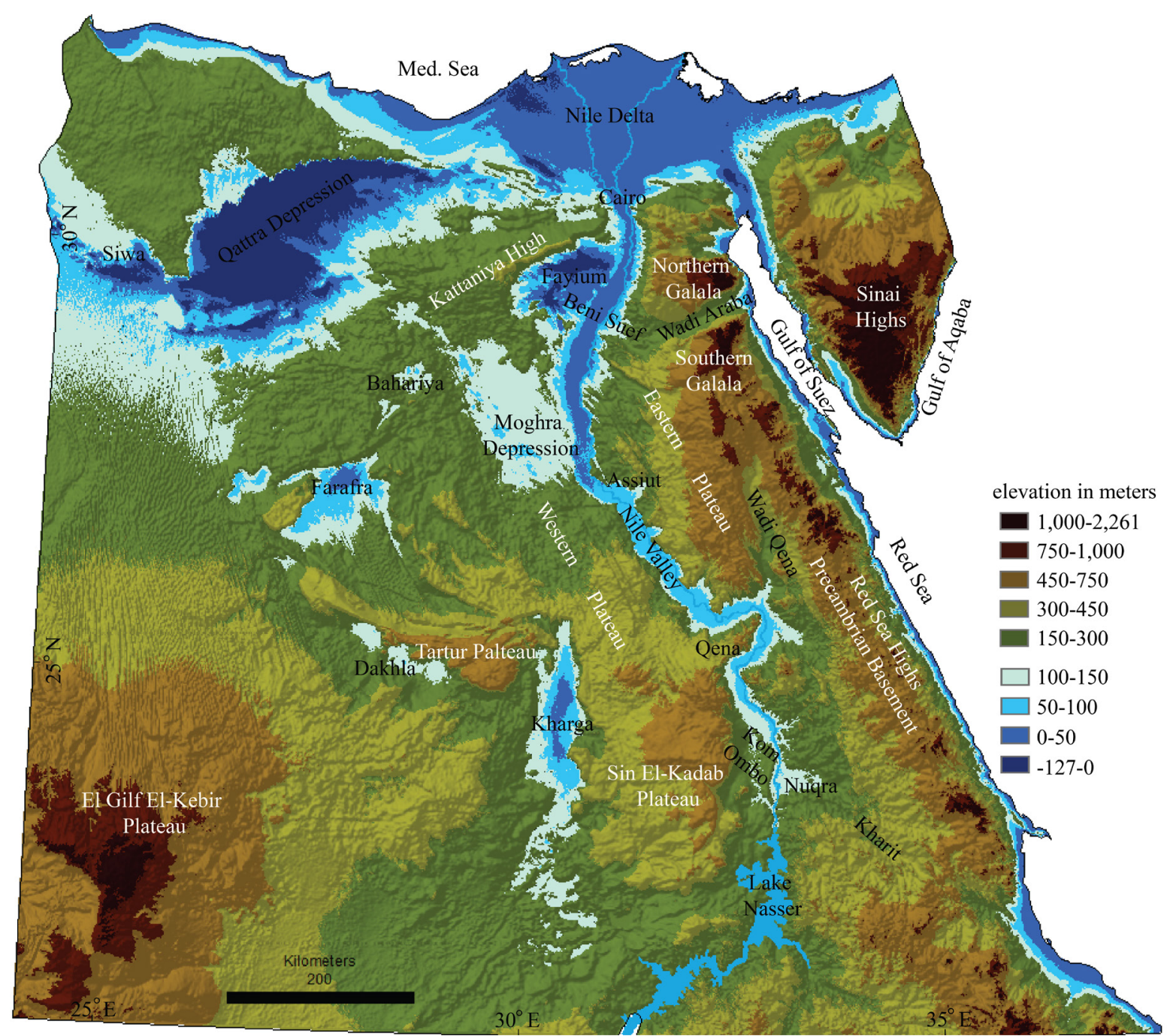

Fig. 1.3. Hill-shaded Digital Elevation Model (DEM) with elevation-levels density slices showing the main morphotectonic units of the Nile System in Egypt. The highs and ridges are labelled in white color, while the depressions, basins and structural grabens are labelled in black.

Since the beginning of the last century, several studies were concerned with the hydrogeology, geomorphology and stratigraphy of the Nile Valley, however, its development history and geodynamic evolution are still widely disputable with comparatively inadequate knowledge of the origin, age and tectonic setting of the river (Fig. 1.3). Most of the previous relevant literature on the Nile were either descriptive or were limited to the geography, morphometry and general geology of the river basin, with some few studies discussed the regional tectonics of the Nile drainage system. Various approaches have also dealt with the evolution of the river in general means that neglected other significant structural elements and controls of the Precambrian Basement fabrics and pre-existing tectonic features. The temporal and spatial relationship between the development of the $\mathrm{RN}$ and successive deformational phases along its course has not been well interpreted. Furthermore, very little is known about the effects of 
the Cretaceous tectonic phases (rifting) in southern and central Egypt whether on the formation of the RN or on the development of a possible Late Paleogene-Early Neogene rifting along its course (Fig. 1.4 \& Fig. 1.5). Most studies have only focused on the hydrogeology of the river with much less interest has been given to the structural setting and subsurface modelling of the Nile Valley. The evolution of the Nile, however, remains unclear with no general agreement on the origin and age of the river and its drainage basin. Hence, this work focuses mainly on the tectonic and structural setting of an important part of the Nile Valley in Egypt, which considered as a lack of satisfactory knowledge in terms of the tectonic framework of the country. The main aim of our study is to extend the current understanding of the evolution of the Nile in the context of the Northeast African and Red Sea-Gulf of Suez rift systems and preceding uplifting processes (Fig. 1.2 \& Fig. 1.3). Although the East African rifting processes and their accompanying volcanism, uplift and extensional tectonics have been intensively studied, their influence on the development of the Nile drainage system, particularly the Egyptian part, has not been sufficiently considered (Fig. 1.2).

This study seeks also to address the structural styles of the proposed Late Paleogene-Early Neogene rifting along the $\mathrm{RN}$, and to explain the present shape of the current segments of the Nile in terms of controlling extensional tectonics, volcanism and regional uplift of the area. The temporal and spatial relationship between development of the addressed Nile rift and the well-studied and tectonically mature Oligocene rift system in the Gulf of Suez will be strongly taken into consideration. In addition, impacts of the Precambrian Basement fabrics and Mesozoic inherited structures and rift basins on the growth and segmentation of the rift and development of the $\mathrm{RN}$ will be highlighted. The study of the typology and spatial distribution of different volcanic occurrences around the Nile Valley is also a significant guiding point to accentuate the nature and architecture of the proposed short-lived rift, and reconstruct its tectonic evolution. I try here to present a three-dimensional structural image of the study area through the integration of multi- (spatial, spectral and temporal) surface and subsurface datasets. 


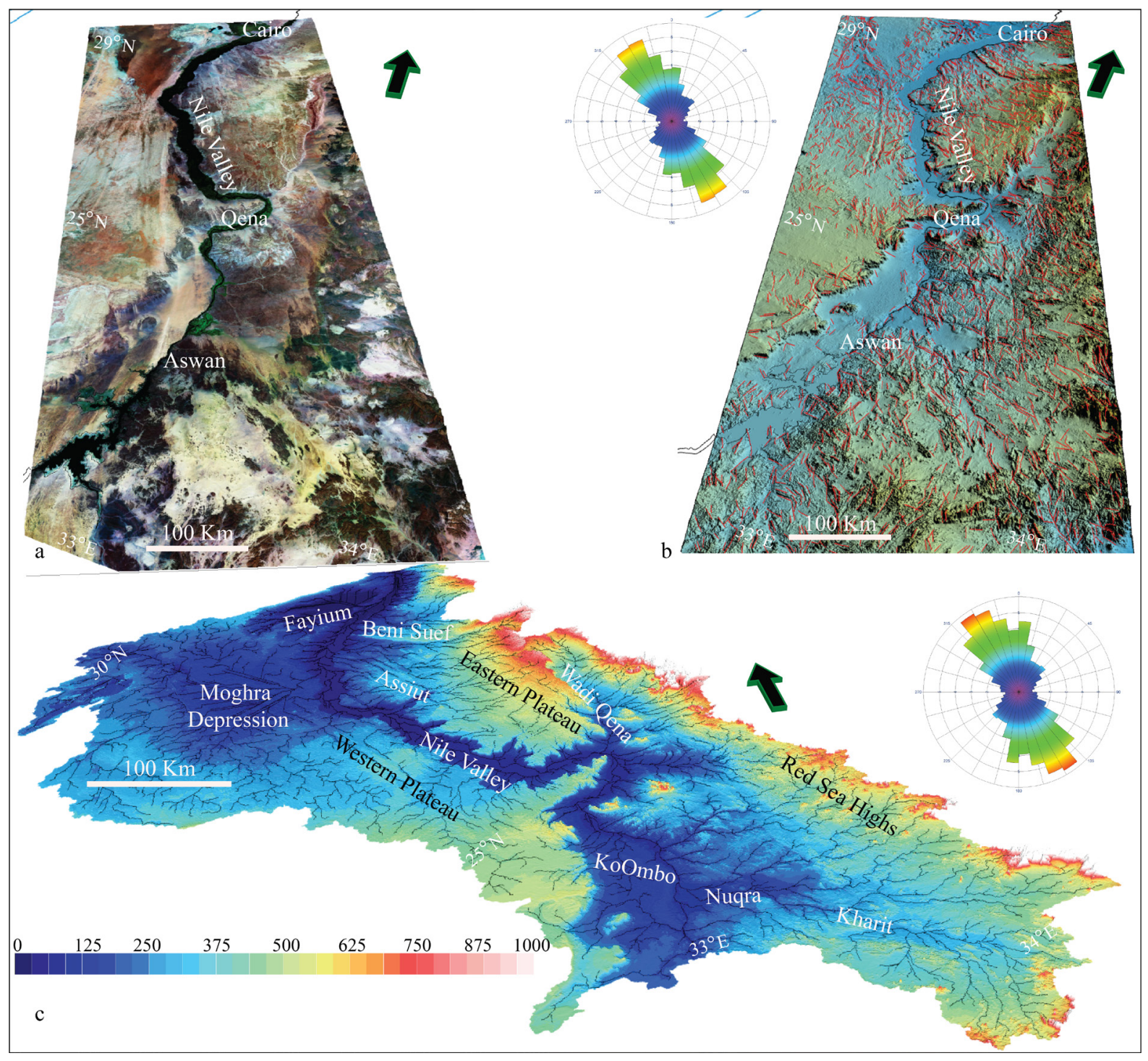

Fig. 1.4. a) Landsat satellite image (bands 752 RGB) of the Nile Valley. b) Digital Terrain Model (DTM) indicates the physiography and structural lineaments of the Nile System (the inset rose diagram shows the NW to NNW predominant trends of the Nile's structural lineaments). c) The Nile basin(s) and their drainage systems (the inset rose diagram shows the main trends of the Nile's drainage; $N W, N N W, N-S$ and $N E$ ).

Sedimentary basins, large rivers and drainage systems develop in different settings, where each setting has its controlling parameters such as type(s) of underlying crust, Mantle dynamic processes, structural position, sediment supply, and large-scale tectonics and inheritance; all change through space and time (McKenzie, 1978; Selley, 1997; Ziegler and Cloetingh, 2004; Cloetingh et al., 2015; Gupta et al., 2020). Here, I also highlight the possible effect of these parameters on the evolution of the proposed short-lived rift along the Nile. As indicated earlier, most of the previous relevant studies on the Nile have discussed and explored stratigraphy, sedimentology and hydrogeology of the rock units surrounding the river, while the structural setting, tectonic evolution and rifting characteristics in this region have been investigated 
neither by concerning the surface structural geology nor by using available subsurface data. Furthermore, the petroleum enterprises have offered less attention for exploration activities along the Nile stretch in Egypt. This might also be one of the reasons for the limited subsurface database and insufficient studies on the structural modelling and tectonic evolution of the Nile $\operatorname{basin}(\mathrm{s})$

Five main distinctions/concepts/questions should be taken into consideration while dealing with the evolution of the River Nile:

1. The drainage systems and sub-basins of major rivers such as the Nile can be reformed through time and space as a result of periodic changes in the geodynamic, tectonic, geomorphic, and hydrologic settings.

2. Whether the study focusses on a specific part of the Nile or it represents a regional investigation of the entire river and its drainage systems?

3. The present-day river represents the descendant of ancestral proto-Nile (s), which have drained the volcanic highlands of the Ethiopian plateau and the Red Sea hills during the Eocene-Oligocene time coinciding with the regional uplift and onset of the East African, Red Sea and Gulf of Suez rift systems (Fig. 1.2).

4. The age and origin of the evolution of each segment of the river along its course must be distinguished from the timing of connection and assemblage of the Nile branches and their drainage basins, which eventually shaped the recent and present-day patterns (Fig. 1.1 \& Fig. 1.4 c).

5. The Evolution of the ancestral RN in Egypt has to be dealt distinctly with a concern that should be given to the role of the inherited Precambrian Basement structures and Cretaceous tectonics. Therefore, this study focusses mainly on the Egyptian part of the ancestral Nile in terms of intracontinental rifting tectonics (Fig. 1.5). the present investigation will also discuss the structural setting of the present-day river and its relation to different segments of the proposed rift and ancestral Nile. 


\subsection{Geologic Setting}

The Nile in Egypt flows in a general NW to NNW direction (Red Sea-Gulf of Suez rift trend), with some of its northern segments have NNE orientation (Gulf of Aqaba trend) (Fig. 1.3 \& Fig. $1.4 \mathrm{c}$ ). In the far south, near Luxor, the river forms its course within a narrow valley that is bounded by steep exposures of Precambrian granites and Cretaceous (Nubian) sandstones on both eastern and western flanks (Fig. 1.5). The Nile Valley shows a northward gradual increase of its width where it cuts further north through Lower and Middle Eocene carbonates of the central plateau. The eastern shoulder of the Eocene plateau is $\sim 300-500 \mathrm{~m}$ higher than the western flanks with a general northward decrease of the elevation of both sides (Fig. 1.3). The successive sea-level falls resulted in severe karstification and erosion of the Eocene carbonates particularly on the western flanks of the Nile Valley with development of unconformities and erosional surfaces along the Eocene-Oligocene, and younger, boundaries (Fig. 1.6 \& Fig. 1.7). This was associated with the incision of canyons and valleys in the Eocene outcrops during the Oligocene-Pliocene time, which were documented along the flanks of the Nile Valley (Fig. 1.7), and were interpreted on several seismic profiles in both ancestral and present-day deltas of the river.

The river and its valley deflect to further WNW direction at the E-W to ENE-trending shear zone and strike-slip faults of Assiut, before it returns to a N- to NNE-flowing direction in the area between Minia, Beni Suef and north Fayium until it bifurcates into two main tributaries (NE and NW trends) forming its delta north to Cairo (Fig. 1.5). The average width of the alluvial Nile Valley along its course is $\sim 15 \mathrm{~km}$. To the northwest of Assiut, the valley opens into a fault-bounded depression (West Assiut-Minia depression) with an older delta composed of Oligocene and Miocene clastics (Moghra Delta) as a clear indication of the older SE-NW flowing direction of the ancestral river(s) (Fig. 1.3 \& Fig. 1.7 e). Both the depression and its delta are structurally controlled with E-W and NW-striking faults forming their southern and western boundaries, respectively. Northwest to Beni Seuf, the river flows westward through a narrow channel that connects the main valley with the alluvial Fayium depression and Qarun lakes (Fig. 1.1). 
The sedimentary cover along the western and eastern stretches of the Nile Valley is represented by Cretaceous to Quaternary deposits, in addition to exposed Precambrian basement rocks in the southeastern margins of the river (Fig. 1.5 \& Fig. 1.6). The eastern and western shoulders of the central Nile Valley are covered mainly by hard and karstified Lower Eocene chert-rich carbonates and well-bedded limestones of the Drunka and Thebes formations, Middle Eocene limestones of the Minia and Mokattam formations as well as the oyster-rich marls of the Upper Eocene Qasr El-Sagha Formation (Said, 1962; 1990b), while Oligocene, Miocene, Pliocene, and Quaternary sediments have wide spatial distribution on the western flanks further north, and particularly in the hangingwalls of NW- and E-W striking faults (Fig. 1.7 a-f). The Lower Eocene Drunka Limestones are either overlain unconformably or incised by channels of the Oligocene gravels of the Katkut formation (Fig. 1.7 g-h).

Volcanic intrusions in the form of NW-trending basalt dikes, sills and flows characterize the eastern and western margins of the present-day $\mathrm{RN}$, with a relatively wide distribution to the north and west (Fig. 1.4 c). Generally, The Nile Valley is controlled along its course by the presence of extensional faults of NW and NNW orientations (rift-parallel trend) in addition to relatively fewer occurrences of E-W, ENE and WNW (Rift-orthogonal/oblique)-striking largescale fractures and smaller segments of oblique-slip faults with frequent dextral-slip components. The western shoulders of the Nile Valley area display numerous folds of different orientations and origin. 


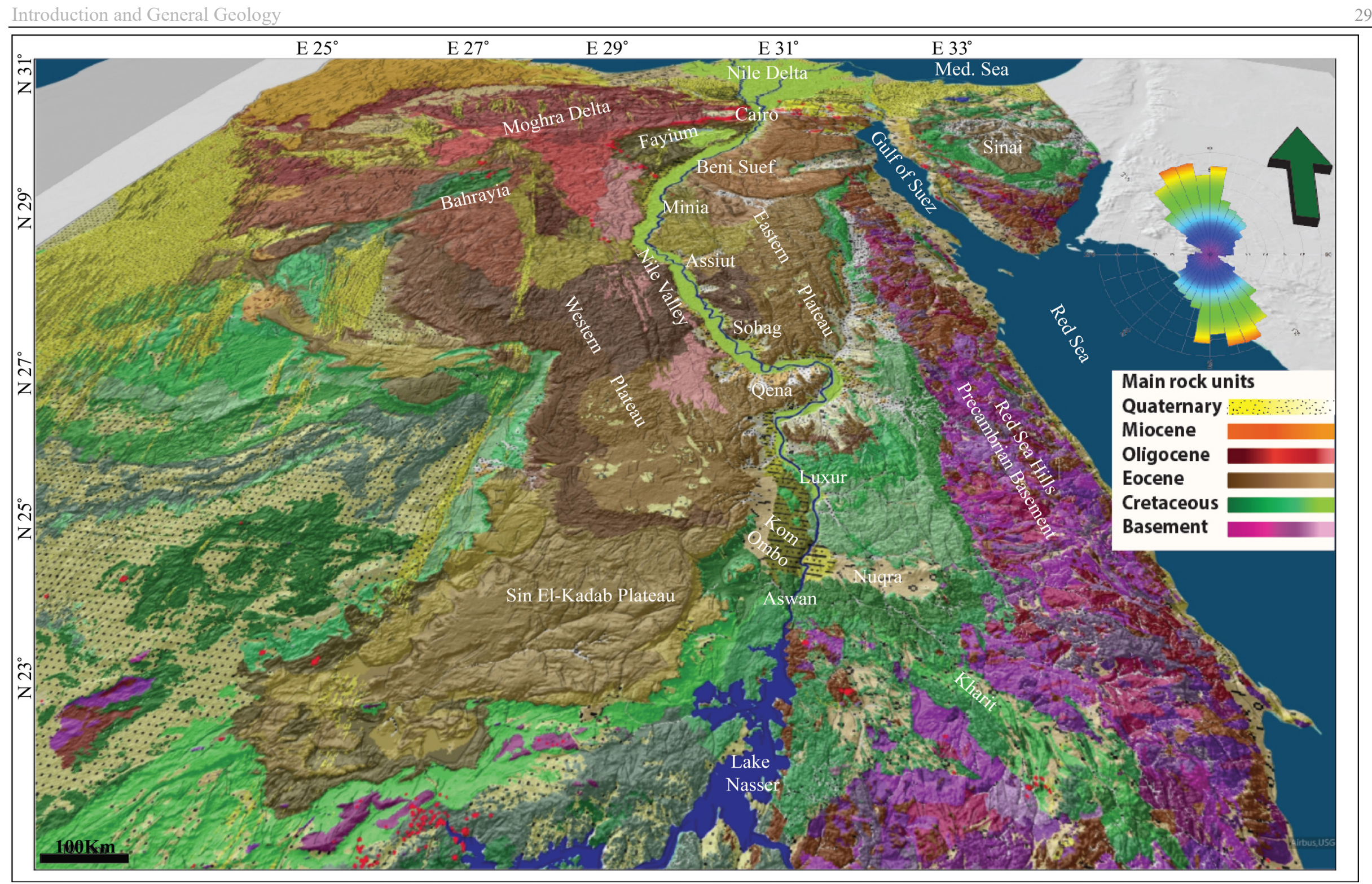

Fig. 1.5. Geologic map of Egypt compiled and modified from different sources cited in the reference list. The stratigraphic units were compiled and modified mainly from Klitzsch et al. (1987). The inset rose diagram shows the strike orientations of the surface structural lineaments and Precambrian Basement tectonic fabrics with dominant NW, NNW and NNE trends. 
Fig. 1.6. General stratigraphy of the Nile Valley area. The stratigraphic units were modified and compiled from Said (1962), (1990b); Klitzsch et al. (1987). Thicknesses are approximated.

\section{Legend}
$\checkmark$ Basalt
- Phosphate
$\exists$ Chalk
Dolomitic Limestone
Cherty Limestone
Sandy Limestone
Limestone
$\because \because$ Talus/Fanglomertaes
$\because \because$ : Sand \&Gravel
Calcareous Shale/Marl
Calcareous Sandstone
Siltstone
$\exists$ Shale
$\because \because$ Sandstone
Basement

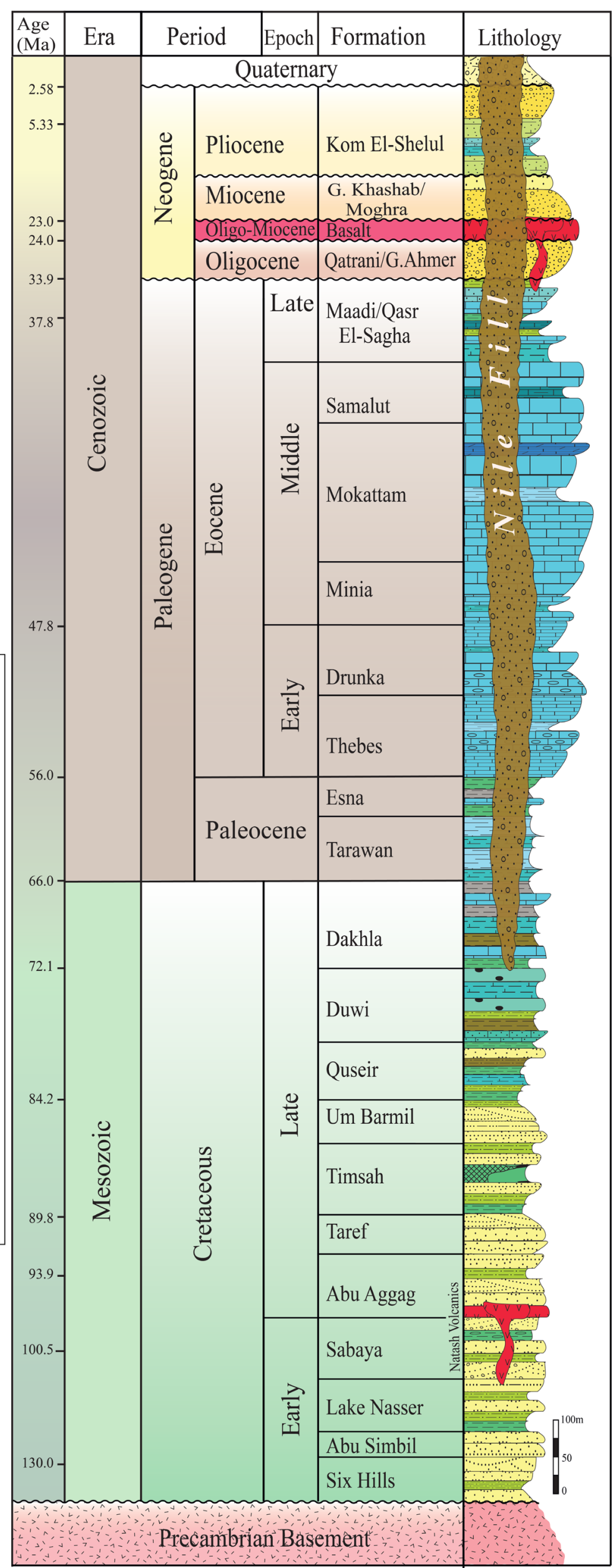

30 


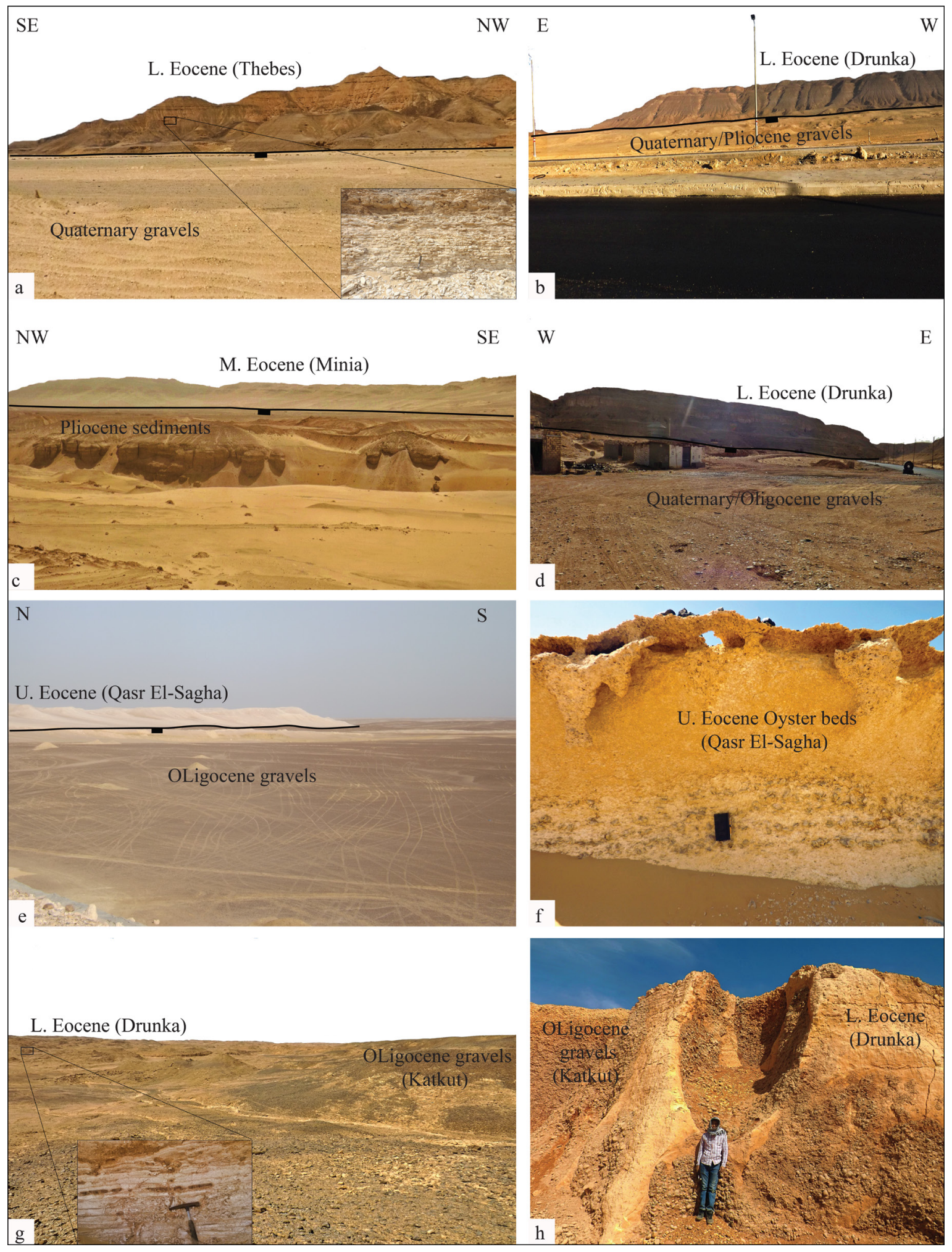

Fig. 1.7. Stratigraphy and field occurrences of the Eocene and Oligocene outcrops along the central and northern shoulders of the Nile Valley. a) The well-bedded Limestones of the Lower Eocene Thebes Formation, east of Assiut. b) Lower Eocene Drunka carbonates along the northern shoulders of Wadi Assiuty, west of the Nile. c) Middle Eocene Minia carbonates in the footwalls of $N W$-striking faults to the east of the Nile. d) Lower Eocene Drunka massive limestones exposed along E-W-oriented faults, west of Sohag. e) Upper Eocene sediments of the Fayium depression in the footwalls of Moghra depression that hosts syn-rift Oligocene gravels. f) The characteristic Oyster beds of the Upper Eocene marls of Qasr El-Sagha Formation, west of Fayium. g) The cherty carbonates of Drunka Formation overlain unconformably by the Oligocene gravels of Katkut Formation to the west of Sohag. h) Channel incisions of the Oligocene clastics along fractures and faults within the Lower Eocene Drunka massive carbonates. 


\section{Chapter 2 Data and Methodology}




\section{Introduction}

This study is based fundamentally on the results of the regional and detailed surface structural mapping, outcrop geology and applications of different remote-sensing processing techniques as well as the subsurface imaging via analysis and interpretation of integrated geophysical datasets. Previous relevant studies on the regional surface and subsurface geology of the Nile Valley area were compiled. The main aim of this study was also to construct a concise threedimensional structural and tectonic framework for the study area, thus we interpreted some available subsurface datasets around the Nile Valley including magnetic and gravity anomaly measurements, 2D and 3D seismic surveys, information from a limited number of boreholes, and some reports on the subsurface geology of the Cretaceous Nile Basins. Many trends of magnetic and gravity anomalies and discontinuities were interpreted here to help to understand the subsurface geology of the Nile.

In an attempt to interpret the tectonic evolution of the proposed rift along the $\mathrm{RN}$ and to explain the main evidences that support the hypothesis of this study, the interpretation results of both surface and subsurface datasets were integrated. Though the available subsurface data are very limited in the central and southern parts of the study area, it contributes significantly to understand the regional geology beneath and around the Nile. This study includes applications of different kinds of remote sensing datasets and GIS analysis together with the field geology aiming to examine the geometry and spatial relationship of surface and near-surface geologic features.

\subsection{Remote Sensing and GIS Analysis}

Remote sensing and GIS applications in geologic mapping focus mainly on the identification of different rock units, geomorphic features and structural elements such as faults, fractures, dikes, Joints, shear zones, folds, etc., and evaluating their physical properties, geometry, mutual relationships and continuous changes through space and time. This based on processing, analysis, classification and visual interpretation of various satellite images such as multispectral, thermal and Radar data measurements. Fieldwork verification of observations and interpretation of the processing and analysis techniques applied on the remotely sensed datasets is very important to achieve reliable geological results. Recently, most of the remote 
sensing data are freely and widely accessible for scientists throughout online gates and data repositories of many organizations and agencies worldwide.

This study utilized a group of algorithms and toolsets available in different software packages (e.g. ArcGIS v.10.7, ArcGIS pro v.2.6.1, ENVI v.5.3, Global Mapper v.20) for pre-processing and processing techniques of optical, thermal and Radar datasets and digital elevation models. The raw and processed datasets and their results as well as the digitized linear and polygonal vector data, such as stratigraphic units, faults, folds and fractures, all were saved in multiple GIS layers. Each layer provides valuable information that contribute to the entire geological framework of the Nile Valley area. This is useful for the superposition of multi- vector and raster datasets at different scales and various levels of processing and enhancement, which helps with the comparison and correlation of surface and near-surface geological and structural features of many layers with different vertical and horizontal resolutions at the same time.

Based on the calibration of different spectral reflectance values and colour balancing of adjacent image scenes, different large-scale mosaics were prepared and then cropped into small-scale views for several regions of interest in the study area. This study applied multistage-image analysis and interpretation at both regional and local scales along the river valley. Structural maps as well as false colour composite RGB images were also draped on digital elevation models to present them as three-dimensional (3D) perspective views with different orientations by using 3D-MOVE (v.2019) and ArcScene (v.10.7.1) software packages (Fig. 2.1). Such a method helps to obtain useful 3D images for the geomorphic and structural elements of the proposed rift along the Nile Valley. ArcGlobe (v.10.7.1) and ArcGIS Earth (v.1.11) were used here to visualize different vector and raster data as well as various kinds of surface and subsurface 2D maps on a 3D globe (see Fig. 1.1 \& Fig. 1.5). By fieldwork verification of processed satellite imagery and digital elevation models, it was possible to modify some stratigraphic units in the study area, which were previously mapped in many works of literature studied the geology of the RN, particularly the early syn-rift Oligocene fluvial clastics (red-sandstone beds and conglomerates) on both eastern and western shoulders of the proposed rift (Fig. 2.2; see Fig. 1.7 g-h). 


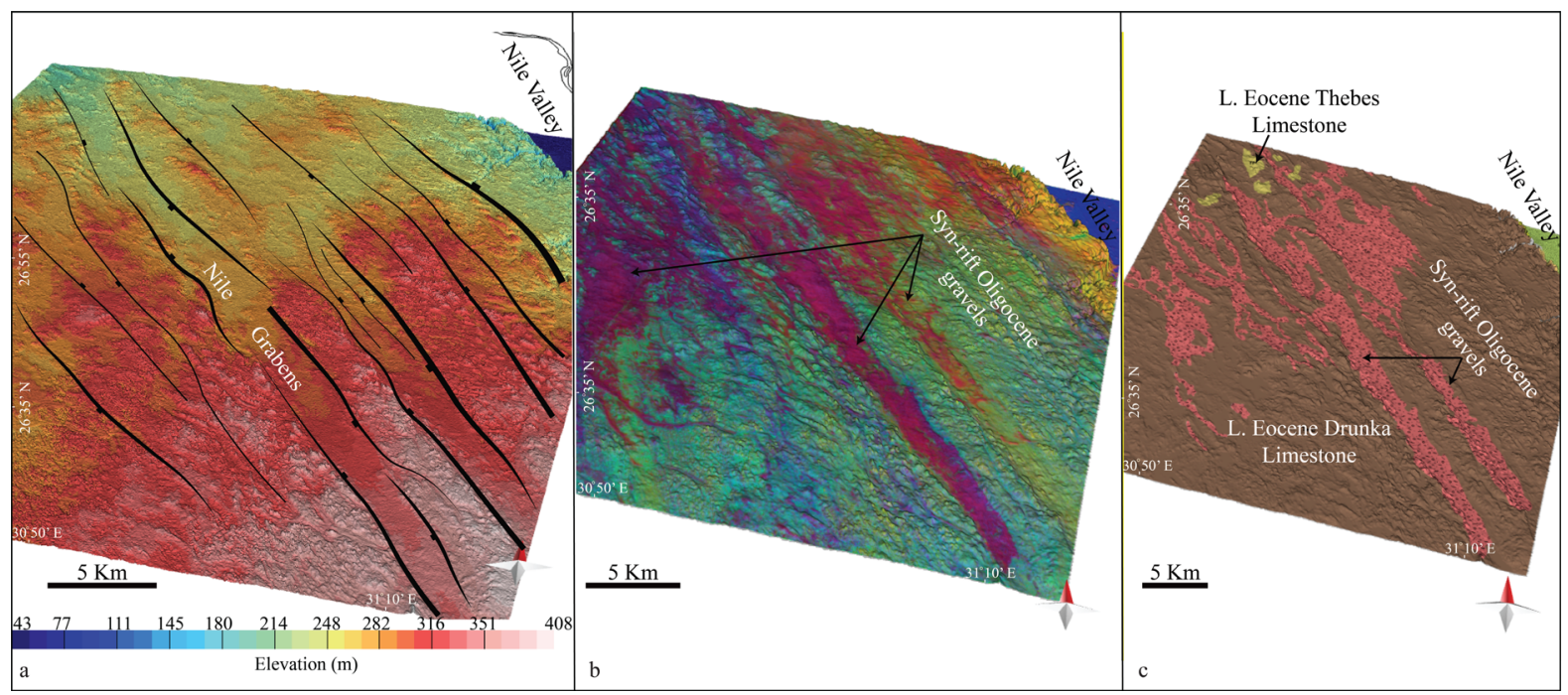

Fig. 2.1. Three-dimensional (3D) perspective views of the western shoulder of the Nile Valley. a) The Nile rift grabens and their bounding $N N W$-striking faults. b) Landsat-8 Principal components 1, 3, 5 RGB image. c) Geologic map of the syn-rift Oligocene gravels filling the structural grabens formed in the Lower Eocene carbonates of the western Nile, west Sohag.

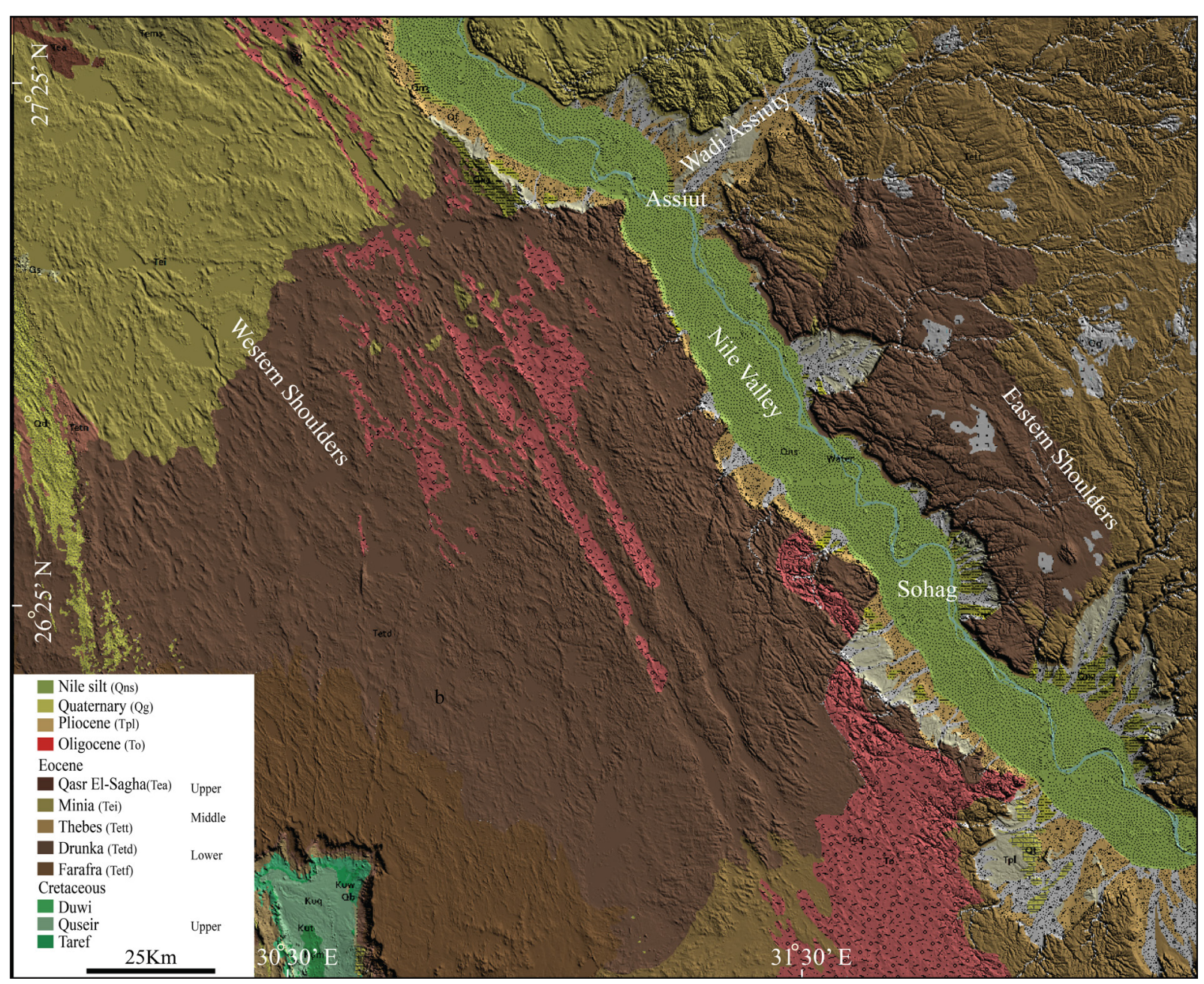

Fig. 2.2. Geologic map of the central Nile Valley draped on Hill-shade DEM showing the distribution of the early syn-rift Oligocene fluvial clastics (red-sandstone beds and conglomerates) in structural grabens and troughs within the Lower-Middle Eocene carbonates. The stratigraphic units are modified from Klitzsch et al. (1987). 
This study presents the interpretation results of satellite images and geological mapping at regional (coarse)-scales of $1: 1,000,000$ to $1: 250,000$ as well as detailed structural mapping at local (fine)-scales of 1:50,000 to 1:10,000 (Fig. 2.1; see Fig. 1.5). The regional-scale mapping of the Nile includes characterization and mapping of regional lineaments, geomorphic features, tectonic fabrics, and large-scale structural elements such as major fault-fold belts, basement mega fractures and shear zones. On these maps, it was possible to characterize the NW to NNW-trending main segments of the proposed rift and their bounding faults as well as the transfers/accommodation zones across their course.

Among several salient geomorphic features at regional-scale in the study area, are the uplifted eastern and western Eocene shoulders along the river valley that also run parallel to the uplifted mountains of the Red Sea-Gulf of Suez rift system (Fig. 2.2). In the area between the eastern shoulders of the proposed rift and the western mountains of the Gulf of Suez rift system, the huge, but presently dry, Wadi Qena cuts its way for $\sim 300 \mathrm{~km}$ from the borders of the Southern Galala mountain in the north to the Great Qena Bend of the Nile Valley in the south. Wadi Qena has a characteristic southward runoff, opposite to the northward flow of the Nile River, which indicates the temporal and spatial differences in the origin and evolution of both drainage systems. The Nile valley opens into a fault-bounded depression that hosts the older delta of the ancestral drainage system to the west of Assiut-Fayium district, which is covered mainly by Oligocene and Miocene fluvial sediments (Fig. 2.3; see Fig. 1.5).

Two major E-W and ENE-trending dextral shear zones along Assiut and Qena dome cut diagonally across the rift system of the $\mathrm{RN}$, and form two major transfer zones oblique to the bounding NW- and NNW-striking rift-bounding faults (Fig. 2.3). The Nile rift shoulders are dissected by hundreds of rift-related fractures, faults and folds parallel to the main canyon of the river. These were developed as the result of extensional tectonics associated with preceding regional uplift, volcanic intrusions and rifting processes. All of these structures are digitized in detail using the processed high-resolution satellite imagery and digital elevation models as basemaps. Interpretations of the mentioned structures and geomorphic features at various 
scales were crucial to recognize the possible origin and geometry of the proposed rift and the ancestral Nile Canyon.

In general, results of applying different remote singing techniques were very helpful to understand the relationship between the proposed Oligocene rifting along the Nile Valley and its temporal and spatial relation with the development of the Ancestral river(s) as well as their connection to the regional uplift and extensional tectonics of the Oligocene-Miocene Red SeaGulf of Sea rift system.

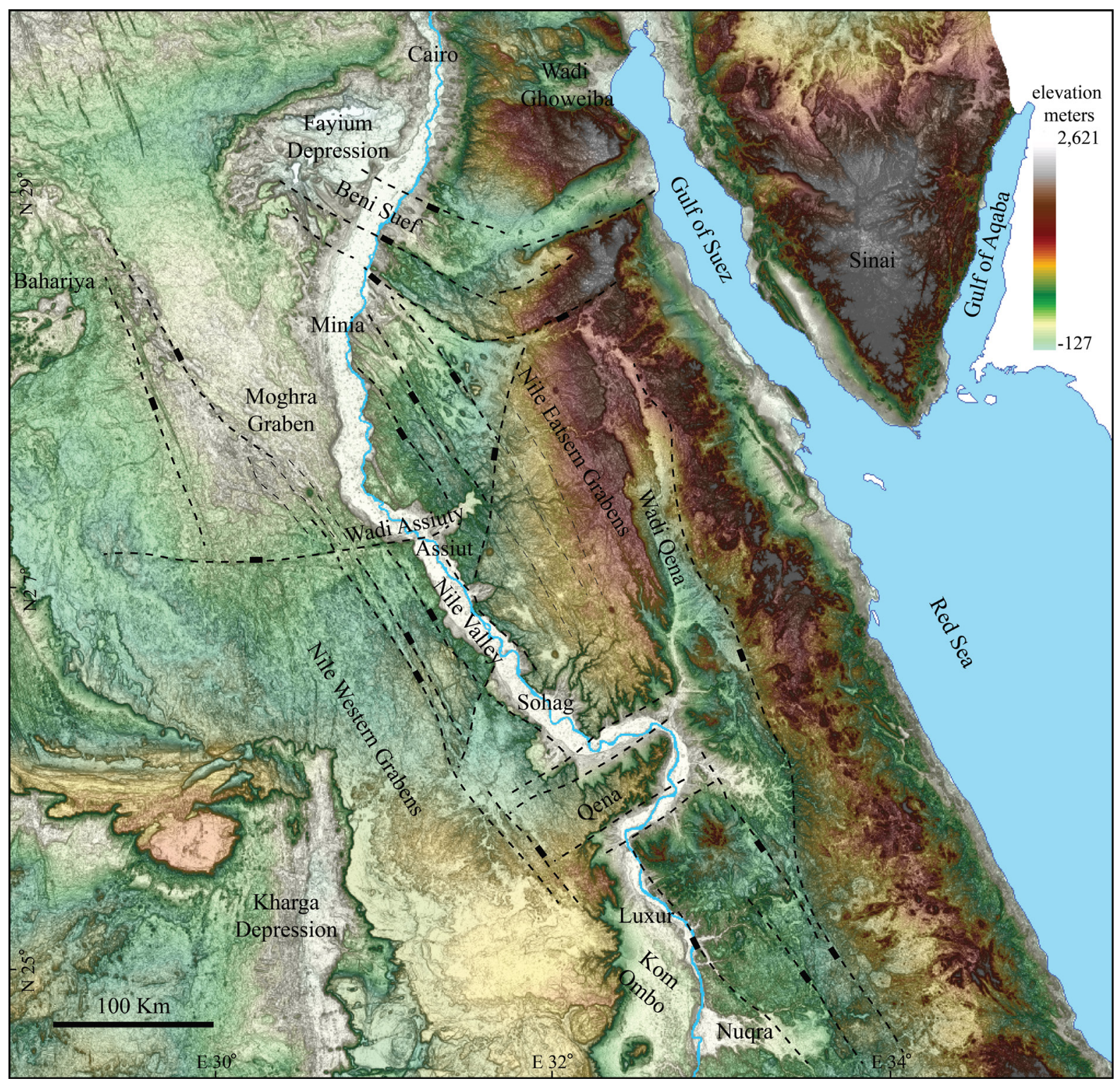

Fig. 2.3. Regional Hillshade relief map derived from DEM showing the major structural elements and morphotectonic units of central and eastern Egypt; the River Nile and Red Sea-Gulf of Suez Rift Systems. 


\subsubsection{Optical, Thermal and Radar data}

The regional and detailed surface geological mapping in different sectors along the $\mathrm{RN}$ were carried out by applying different image processing techniques on recently acquired multispectral satellite images of different spatial, spectral, temporal and radiometric resolutions. The optical remote sensing data used in this study are the Advanced Spaceborne Thermal Emission and Reflection Radiometer (ASTER), Landsat- 8 and Sentinel-2 images. The Radar Data were also valuable to detect several interesting features in the study area such as paleo-drainage systems and inverted channels on the eastern and western flanks of the Nile Valley. Two examples for the Radar data were analysed in this study, the Advanced Land Observing Satellite-Phased Array type L-band Synthetic Aperture Radar (ALOS-PALSAR) and Sentinel-1data. In addition, we have also used the high-resolution Google-Earth imagery for local-scale and detailed structural and geological mapping.

Landsat- 8 and ASTER are imaging instruments that represent the product of cooperation between the National Aeronautics and Space Administration (NASA), the United States Geological Survey (USGS), the Ministry of Economy, Trade and Industry of Japan (METI, 2019), Japan Aerospace Exploration Agency (JAXA). ASTER is a Japanese-built multispectral imaging system launched onboard TERRA satellite platform on the Earth Observing System (EOS) in December, 1999. The Landsat-8 was launched in California in February 2013, as the most recently launched Landsat satellite. The Sentinel missions are the result of the collaboration between the European Space Agency (ESA), European Commission initiative GMES (Global Monitoring for Environment and Security), CNES French space agency, Airbus Defence and Space, German Aerospace Centre (DLR). The Sentinel-2 mission consists of two satellites; the Sentinel-2A satellite was launched by ESA in June 2015. The second identical satellite (Sentinel-2B) was launched in March 2017.

The ASTER operating sensors receive and measure the reflected radiations in 14 spectral bands covering the Visible-and-Near Infrared (VNIR, 3 bands), Shortwave-Infrared (SWIR, 6 bands) and Thermal-Infrared (TIR, 5 bands) wavelength spectral regions with spatial resolutions of 15, 30 and $90 \mathrm{~m}$ respectively. The dimensions of each ASTER scene are $60 \times 60 \mathrm{~km}$. VNIR bands of satellite data are sensitive to the presence of iron oxides (hematite, goethite, jarosite) and 
Rare Earth Elements, while the SWIR bands can be helpful to detect clay-bearing minerals such clays and phyllosilicates (Hunt, 1977). The TIR bands are useful to characterize silicates and carbonates (Salisbury, 1987). The Landsat-8 instrument operates with two sensors, the Operational Land Imager (OLI) and the Thermal Infrared Sensor (TIRS). The east-west width of each Landsat- 8 scene is $185 \mathrm{~km}$, while the north-south dimension is $180 \mathrm{~km}$. The OLI sensor collects data in four bands in the visible, one in the near-infrared, and three in the shortwave infrared wavelength spectral regions, all at $30 \mathrm{~m}$ spatial resolution, as well as a visible panchromatic band that of $15 \mathrm{~m}$ resolution. The TIRS collects data in two long-wavelength thermal infrared bands at $100 \mathrm{~m}$ spatial resolution. This work used "Level 1T" Landsat-8 images acquired in 2019-2020, which are orthorectified (terrain corrected), radiometrically corrected, and co-registered to UTM projected coordinate system (WGS84 datum, Zone 36N). The Sentinel-2 Multi-Spectral Instrument (MSI) acquires 13 spectral bands ranging from Visible VNIR to SWIR wavelengths, 4 VNIR bands at $10 \mathrm{~m}$ resolution, 6 SWIR bands at 20 $\mathrm{m}$, and 3 bands at $60 \mathrm{~m}$ (vary between VNIR and SWIR).

The digital image-processing techniques applied here were based mainly on the analysis of the characteristic spectral signatures, visual interpretations and fieldwork verification of different rock unit exposures in the study area. The Radar images are useful to investigate the nearsurface features such as paleo-drainage systems (Lillesand et al., 2015). The results of digital image-processing techniques that were applied on ASTER and Landsat- 8 in this study can be summarized as follows; (1) False Colour Composites (FCC), different band combinations viewed as RGB images. (2) Band Ratio Transformation images. (3) Principal Component Analysis (PCA). The selection of bands to be used in FCC, band-ratio and PCA techniques depends on the spectral signature analysis of the selected exposed rock units in the region of interest (Jensen, 2016). 


\subsubsection{False Colour Composites (FCC)}

The ASTER false colour composite images are very useful for the geological mapping, especially for identification of the rocks and alterations (Jensen, 2016). Many geologists believe that reflection in spectral bands around 1.6 and $2.2 \mathrm{~mm}$ is particularly important for mineral exploration and lithologic mapping (Chuvieco, 2016). The Red-Green-Blue (RGB) false colour composite images of the ASTER, Sentinel-2 and Landsat- 8 bands combinations are presented here after image enhancement processing using contrast stretching (linear-stretch technique) with lower and upper cut-offs of $2 \%$ and $98 \%$.

In conclusion, the visual interpretation and spectral signature analysis of different exposed rock units in the study area revealed that the false colour composite images of Landsat- 8 bands $(7,5,1)$ and Sentinel-2 bands $(11,8,2)$ in RGB could be efficiently used for better lithological discriminations (Fig. 2.4 a \& b). However, it is still hard to recognize all rock units covering the study area on a single image of one of the proposed band combinations. The results show also that using the RGB false colour composite image of ASTER bands (125) can be a helpful tool to distinguish the Oligocene gravels, conglomerates, and sandstone beds whose spectral reflectance signatures have unique patterns compared with other rock units exposed around the Nile Valley, which made up mainly of Eocene carbonates (Fig. 2.4 c). The RGB image of ASTER bands (834) can be utilized to characterize the Oligo-Miocene basalt occurrences comparative to the surrounding sedimentary rock exposures (Fig. 2.4 d).

\subsubsection{Band Ratio Transformations}

The band-ratio technique is the ratio of one band to another. It is applied simply by dividing the digital number (DN) of each pixel in one band by the $\mathrm{DN}$ of another band, and the resulting new values are plotted as an image (Liu and Mason, 2016). This is used to display spectral variations, and to neglect some common features such as the effects of illumination conditions. The current work has extracted some useful information from band-rationing of Landsat- 8 data such as the application of $(5 / 4,3 / 1,7 / 5)$ in RGB that can be used to differentiate between the basalt and Oligocene gravels along the shoulders of the Nile, which have similar appearances in both true and false colour composites of most of the processed bands (Fig. 2.5 a \& b). 
The Landsat- 8 RGB image of the band ratio $(7 / 2,6 / 1,2 / 3)$ is helpful to distinguish between the Oligocene gravels and Quaternary wadi deposits (gravels, boulders and fanglomerates) (Fig. 2.5 c \& d).
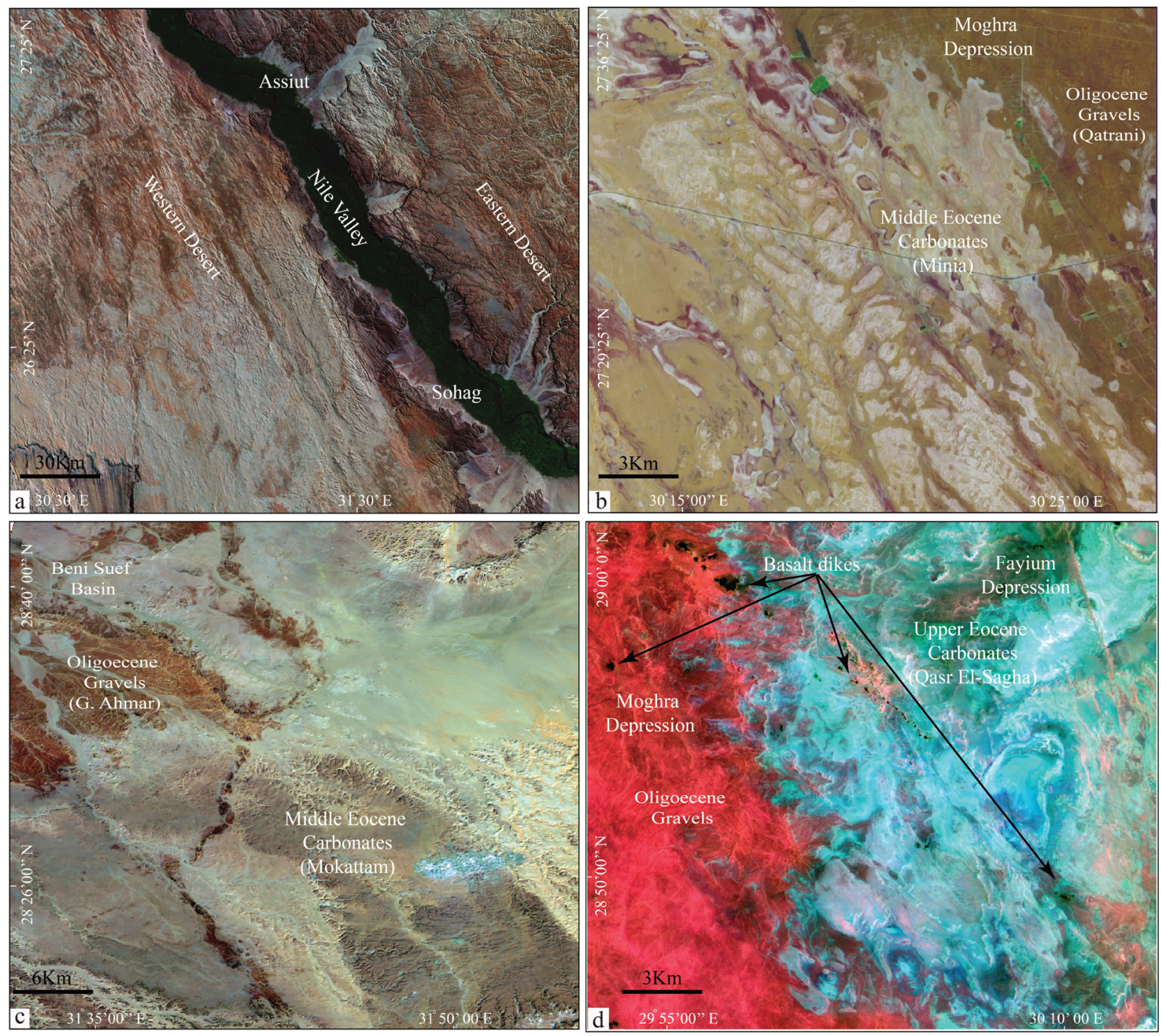

Fig. 2.4. False Color Composite RGB images using Landsat-8, Sentinel-2 and ASTER bands. a) Landsat-8 bands 7, 5, and 1 in RGB. b) Sentinel-2 bands 11, 8, and 2 in RGB. c) ASTER bands 1, 2, and 5 in RGB. d) ASTER bands 8, 3, and 4 in RGB. These RGB False Color Composite images help to discriminate between the pre-rift Lower-Middle Eocene carbonates, the syn-rift Oligocene-Miocene gravels and conglomerates, rift-related basalt volcanic occurrences and the Post-rift PlioceneQuaternary clastics and fluvial sediments. 


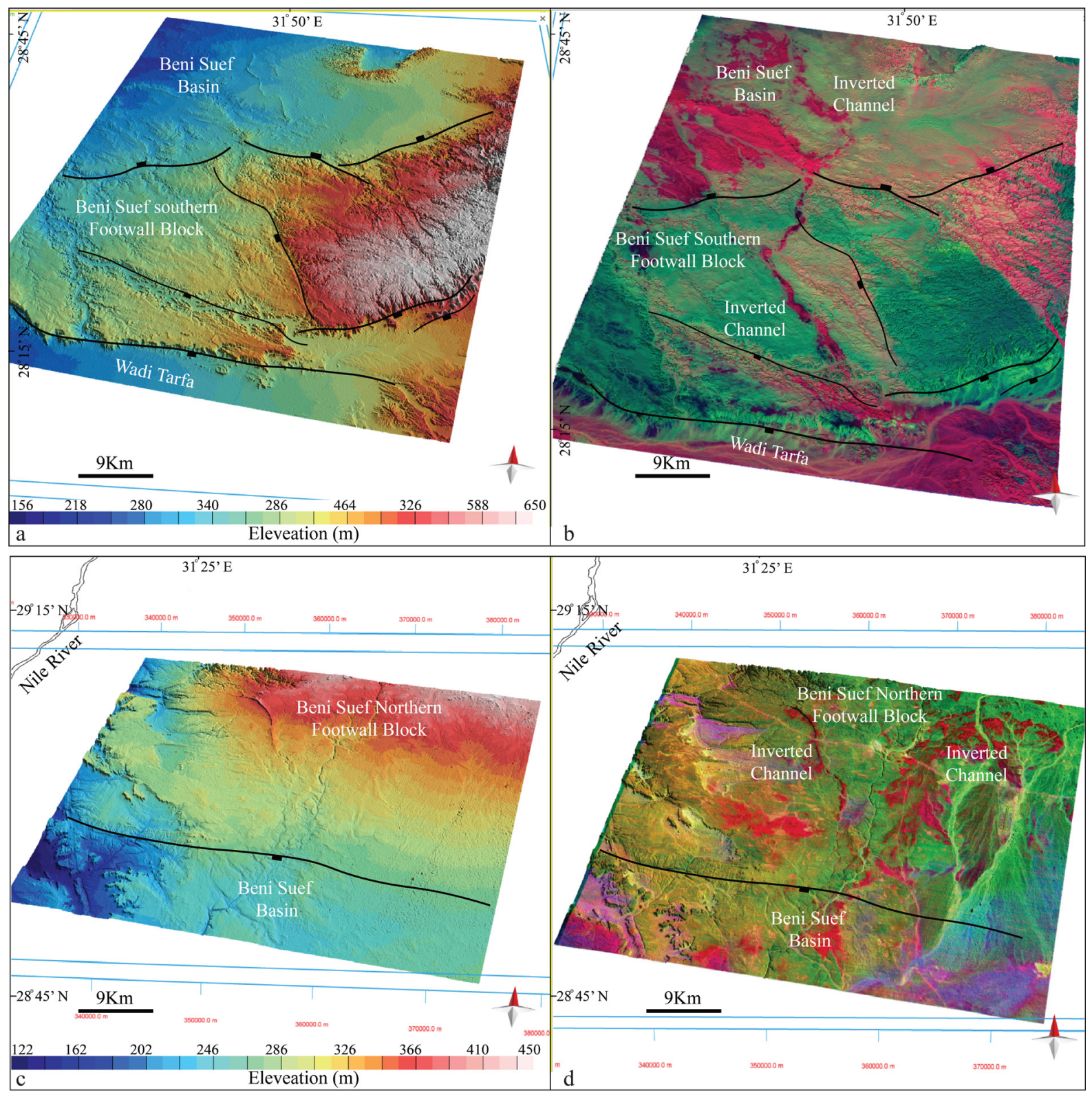

Fig. 2.5. (3D) perspective views of East Beni Suef basin. a) DEM of Beni Suef fault blocks, notice that the resolution is not quite enough to characterize the inverted topographies (channels). b) RGB image of the Landsat-8 band ratios 5/4, 3/1, 7/5. c) DEM of the northern part of East Beni Suef basin. d) RGB image of the Landsat-8 band ratios 7/2, 6/1, 2/3. These band ratios in figures $b \& d$ are used here to characterize the early syn-rift Oligocene gravels (in red colours) of the Nile basins and grabens, such as East Beni Suef in this example. The yellowish-greenish colours represent Middle Eocene Carbonates.

\subsubsection{Principal Component Analysis (PCA)}

Principal Component Analysis (PCA) is a popular mathematical technique that has been widely used for analysing multivariate problems in social, political and natural sciences. The primary objective of the PCA technique is to characterize a large group of variables into a new smaller set, without losing a significant amount of original information (Chuvieco, 2016). In remote sensing, this usually includes the analysis of multispectral satellite data aiming to reveal complex interrelationships between multivariate spectral signatures to distinguish independent 
sources of variability, and to compress the spectral data by removing redundant spectral information present in the multiband images (decrease of data redundancy) (Lillesand et al., 2015; Chuvieco, 2016). A primary benefit of this technique is the ability to separate the multivariate data into independent sources of variability, which in linear combination can reconstitute the original data with minimal loss of information. When the image has numerous spectral bands, they frequently contain redundant information either because those bands are in similar spectral regions or because some features have similar radiances across spectral regions (Chuvieco, 2016). The PCA processing technique allows us to remove information redundancy that is usually found in multispectral datasets such as spectral satellite data.

The output of applying PCA on a multiband image is a new smaller dataset including the significant spectral signatures with minimal loss of original values (dimensionality reduction). This is obtained by applying a mathematical approach called Eigen-analysis that decomposes the original spectral data of a multiband image into a new set of abstract Eigenvectors with associated eigenvalues (Jensen, 2016). This processing technique is very useful in remote sensing applications, for example, to choose the best RGB band combinations for false colour composite images, which can be used to discriminate variable rock units, to distinguish specific lithology, and to characterize structural and linear features in a multiband dataset.

The principal PCA is also used to reduce the relief effects, and to extract the most relevant information from different bands (Chuvieco, 2016). The PCs colour images usually show remarkable lithological variations of the examined rocks in the region of interest. The PCA were applied here on the optical bands of ASTER and Landsat-8 datasets for lithological discrimination and structural mapping of some selected region of interest along the Nile Valley (Fig. 2.6). 


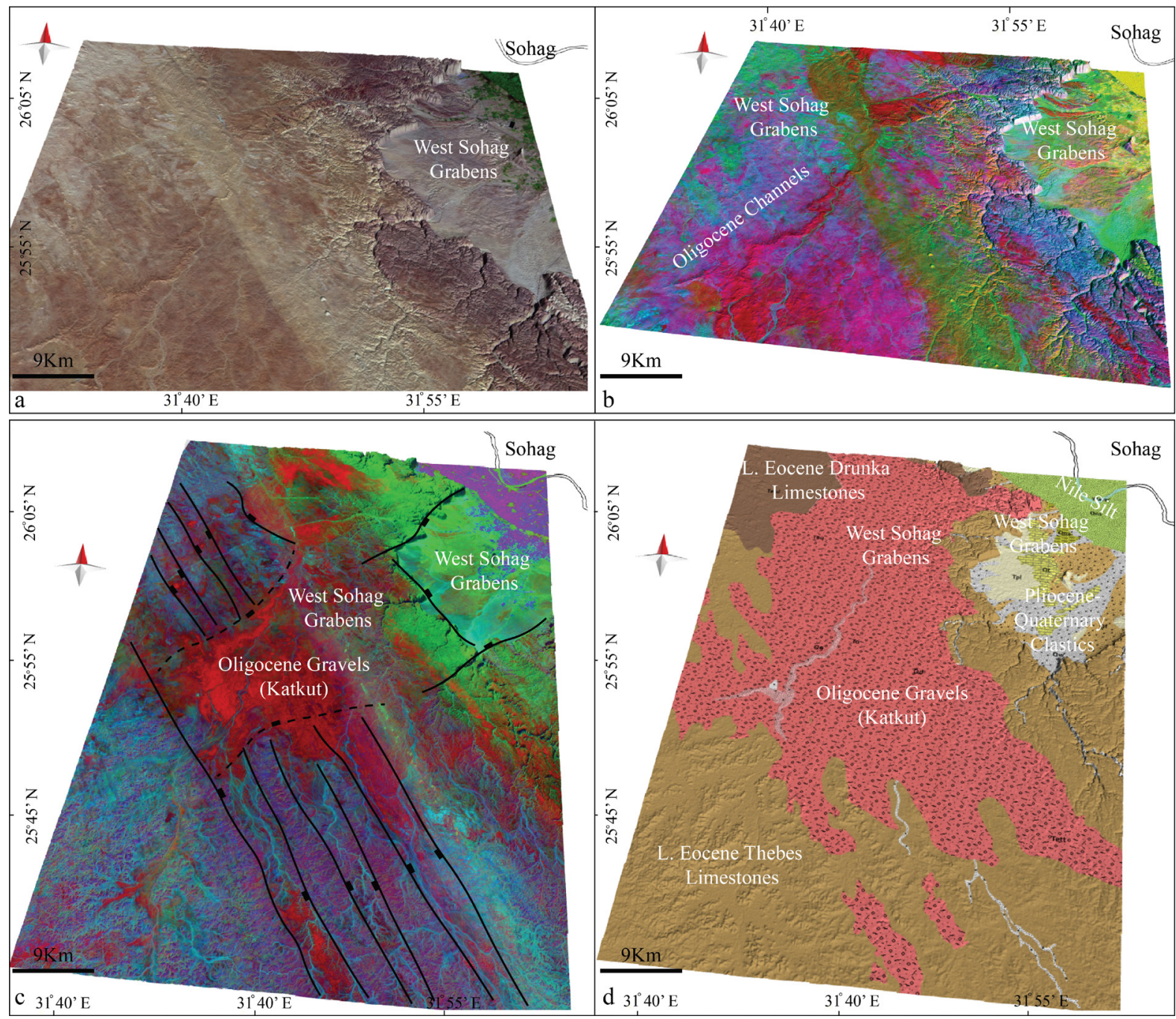

Fig. 2.6. (3D) perspective views of Western Sohag Grabens. a) Sentinel-2 FCC image of bands 11, 8,2 in RGB, which doesn't help to characterize the structural elements as well as the different rock units in this area. b) RGB image of the ASTER PCS $3,5,1$. c) RGB image of the Landsat-8 PCs 7, 4, 3; with interpretational of the main grabens-bounding extensional faults of $N N W$ trends. Integration of these PC images was very effective to reveal the Oligocene inverted channels that filled the earlyformed rift grabens with syn-rift fluvial gravels, conglomerates and sandstones (red colours). This was also useful to recognize the rift-related faults west of Sohag. d) A modified geological map of the Western Sohag Grabens.

\subsubsection{Digital Elevation Models (DEMs)}

The most common digital data of the shape of the earth's surface is cell-based Digital Elevation/Terrain/Surface Models (DEMs/DTMs/DSMs). This data is used as input to quantify the characteristics of the land surface. A DEM is a raster representation of a continuous surface, usually referencing the surface of the earth. The accuracy of this data is determined primarily by the horizontal resolution (the distance between sample points). The elevation data used in this study are of different horizontal resolutions $(\sim 1000, \sim 225, \sim 90, \sim 30$ and $\sim 12 \mathrm{~m})$. The DEMs data are provided by different agencies and organizations such as NASA, USGS, DLR, and JAXA. Examples for the elevation models used here are; the Global Digital Elevation Model 
$\sim 1 \mathrm{~km}$ resolution (GTOPO30), TerraSAR-X add-on for Digital Elevation Measurements $\sim 90$ \&12m (TanDEM-X), Shuttle Radar Topography Mission 30m (SRTM v.3) and a modified version by the Consultative Group for International Agricultural Research 225m (CGIAR, SRTM v.4.1), ASTER Global Digital Elevation Model 30m (ASTERGDEM v.3), ALOS Global Digital Surface Model World 3D-30m (ALOS-AW3D30). The elevation data were projected to the Universal Transverse Mercator (UTM, WGS84 datum, Zone 36), and then mosaicked and cropped to construct topographic models of the continental-, regional- and local-scale regions of interest along the Nile Valley.

DEMs can be used to derive a wealth of information about the morphology of a land surface for instance slope, aspect, and shaded relief information (Jenson, 1991). Several surface or terrain features can be extracted from DEMs such as the topographic gradient angle (slope) and its orientation (Aspect), hydrogeological parameters and structural lineaments. Therefore, processed DEMs with different spatial relations were utilized in the geological mapping of the study area along the Nile Valley. The relatively low-resolution DEMs $(\sim 1000, \sim 225, \sim 90 \mathrm{~m})$ were used to produce topographic, hillshade, terrain and slope models for large-scale features such as transcontinental or country-scale morphotectonic features, large-scale lineaments, shear zones and landforms. While the interpretation of data from high-resolution DEMs and DTMs ( $\sim 30 \& \sim 12 \mathrm{~m})$, were helpful to recognise slight-but-significant topographic variations at fine detail levels along the eastern and western flanks of the Nile Valley. These were also suitable to detect and map several geomorphic and structural key elements in detail such as folds, fractures and faults; all are of small-scale outcrops. Data from DEMs were processed for topographic and terrain modelling, drainage networks and watersheds analysis, and lineaments extraction.

\subsubsection{Terrain Modelling (Hillshade, Aspect and Slope)}

The Hillshade function in GIS produces a grayscale 3D representation of the terrain surface, with the sun's relative position taken into account for shading the image (ESRI, 2020). Mountain hillshading is a useful algorithm for visualizing topography and terrain by applying an illumination source (the sun) and the slope and aspect of an elevation surface (DEM). It provides two options for generating hillshade models based on the direction of the light source. 
The first is the traditional hillshade that applies an illumination source from one direction using the altitude and azimuth values to specify the sun's position. The second is the multi-directional function that combines light from multiple sources or directions (usually six different directions) to represent an enhanced visualization of the hillshade terrain and to improve the appearance of regions with low relief. The advantage of the multidirectional hillshade is that more detail is displayed in areas typically affected by oversaturation and deep shadows than when using the traditional hillshade method, which help improving the terrain visualization (ESRI, 2020).

Both algorithms of the traditional and multi-directional hillshade terrain were used here as a relief background to produce 3D geological, topographical, structural and hydrological maps and perceptive views (Fig. 2.7). In addition, the two Hillshading functions were imported in the processing of the DEMs for other applications such as hydrogeological (Watershed) analysis and extraction of structural lineaments. In the traditional hillshade terrain modelling, the properties of altitude and azimuth together indicate the sun's relative position that is used for creating any 3D model (hillshade or shaded relief). Altitude is the sun's angle of elevation above the horizon that ranges between $0-90^{\circ}$, while azimuth is the sun's relative position along the horizon, which is indicated by the angle of the sun measured clockwise from due north and ranges between $0-360^{\circ}$. This study used an azimuth angle that ranges between $045^{\circ}$ and $060^{\circ}$ with an altitude of $45^{\circ}$.

Another two useful tools available in the terrain modelling in ArcGIS are the Slope and Aspect. The Slope function calculates the rate of change of elevation for each DEM pixel and represents the steepness of topographic surfaces (ESRI, 2020) (Fig. 2.7 a). The Aspect function creates a raster layer that simultaneously displays the aspect and slope of a surface. It identifies the downslope direction of the maximum rate of change (i.e. slope direction). These tools were applied here on DEMs to produce 3D maps that show significant structural elements and volcanic-related geomorphic features as well as remarkable topographic variations and along the Nile Valley (Fig. 2.7). 

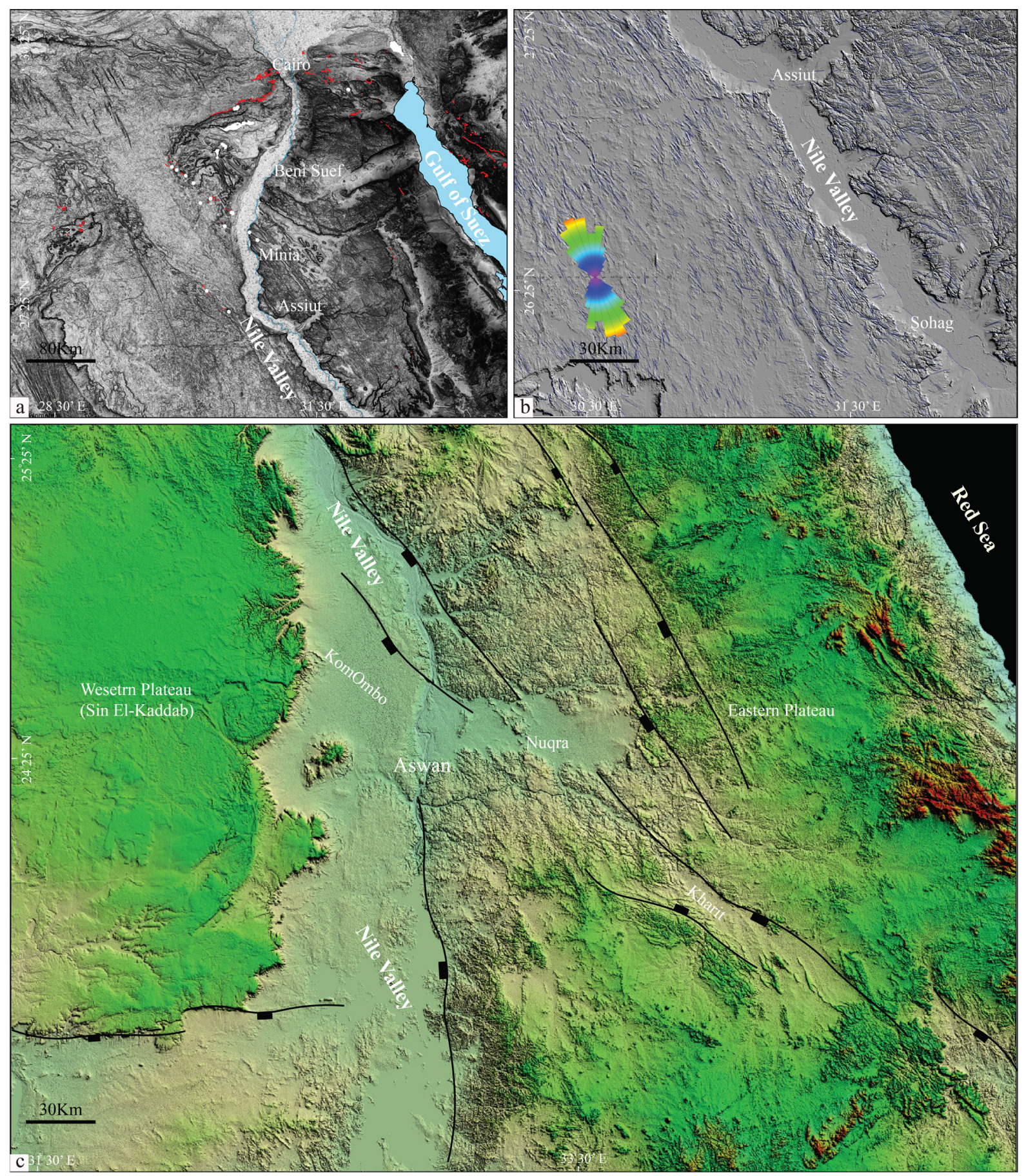

Fig. 2.7. Different terrain models extracted from DEM data of different resolutions. a) Slope model for the central-northern Nile showing the mega shears and fractures. It also indicates the spatial distribution of the rift-related basalt volcanic occurrences of the Nile and Gulf of Suez Rift Systems as well as the sampling sites of the Nile volcanics used in this study (white dots). b) Multi-directional greyscale Hillshade model with the controlling structural lineaments of the central Nile. The inset rose-diagram show the main trends of the structural lineaments of the Central Nile. c) Tinted Hillshade model showing the main structures and tectonic elements of the Southern Nile rift basins with simple structural interpretation of the riftbounding extensional faults. 


\subsubsection{Lineaments Extraction}

A lineament is a mappable, simple or composite linear feature of a surface, whose parts are aligned in a rectilinear or slightly curvilinear relationship, and which differs distinctly from the patterns of adjacent features and presumably reflects a subsurface phenomenon. (Hobbs, 1904; O'LEARY et al., 1976). Geologic lineaments commonly represent rectilinear geomorphic features, tectonic fabrics or structural elements that appear remarkably higher or lower in brightness level relative to their neighbours on aerial photos, satellite images and processed DEMs such as the greyscale 3D terrain models (e.g. hillshade, slope, and aspect). They are frequently reflected as ridges and valley lines including fractures, fault zones, Joint sets, cleavage belts, structural fissures, tectonic crush zones, linear fold and volcanic arrangements, large crustal fractures, deep and buried faults, linear micro-geomorphological features (Vassilas et al., 2002).

Lineaments are scale-related composite surface features (either segmented or complex) that are characterized by alignment in a distinct direction, which usually conform to a regional trend (O'LEARY et al., 1976). They may reflect discontinuity surfaces in the rocks or may also reflect geological structures, topographic features, or human-made features (Qari, 2011). The surface lineaments frequently represent deeper geological structures that reveal significant tectonic elements in the crust and mineralization zones, and also control the distribution of groundwater, geothermal resources, tectonic movements, volcanic activities, earthquakes, and geomorphic features (Han et al., 2018). Lineaments are usually extracted manually or automatically from remote sensing imageries by applying some computation algorithms in software packages such as PCI Geomtica. This is one of the advancing digital geological mapping techniques, whose results are usually verified by fieldwork investigations.

The manual, automated or semi-automated extraction of geological lineament using different remote sensing data in addition to the statistical analysis and interpretation of their trends and density distribution might contribute significantly to understand the geometry, orientation and development history of morphotectonic systems. An example in this study is the proposed rift along the Nile Valley and related grabens, folds, fractures, volcanic intrusions and extensional faults. The different trends of structural lineaments might also imply temporal changes in the 
regional plate movements. Analysis of structural lineaments could also help in the investigation of movements in tectonically active areas, their possible control on the geometry and distribution of geological hazards, landslide risk assessment and earthquakes.

Several factors might influence the automatic and manual detection of lineaments and other topographic features of geologic significance, for instance, the angular relationship between the linear feature of the illumination source, which is determined by the position of the sun (the azimuth and altitude angles) (Lillesand et al., 2015). Many of the mapped lineaments in the current study were extracted by applying an approach that is based on using hillshade-relief models of the DEMs as a background for the computation process (Fig. 2.7 a). The azimuth and altitude angles of the illumination source (the sun) are set to optimize the interpretability of the subtle topographic and structural linear features. Many linear geologic features can be detected either manually or automatically using hillshade terrain models with reliable vertical exaggeration values.

The structural lineaments that have strike directions orthogonal or highly oblique to the azimuth angle of the illumination source are generally extracted with more consistency and accuracy than those that have parallel or semi-parallel trends. In addition, moderate illumination angles (altitude $\sim 30^{\circ}-45^{\circ}$ ) are preferably used for the extraction of subtle structural and geomorphic lineaments. Therefore, azimuth and altitude angles of values range between $\left(045^{\circ}-060^{\circ}\right)$ and $\left(30-45^{\circ}\right)$, respectively, were applied on both optical and elevation datasets used in extracting lineaments (Fig. 2.8). An alternative method was proposed by Lillesand et al. (2015), is to use imaging radar whose side-looking configuration can be used to accentuate the subtle topographic and tectonic features.

This study dealt with semi-automated extraction, analysis, mapping and interpretation of structural lineaments at various regional and detailed scales using an integrated combination of satellite datasets of different horizontal resolutions such as Landsat-8, Sentinel-2 and ASTER images as well as data from DEMs (e.g. SRTM v.3 \& v.4, TanDEM-X and ALOSAW3D30). The Landsat-8 and Sentinel-2 satellite imageries provide high-resolution Panchromatic bands with 15 and 10 m horizontal resolution, respectively. The results of Han et al. (2018) showed that using some algorithms for extraction of lineaments from DEMs and 
satellite images can reflect the direction and trend of geotectonic movements regardless of the relatively thick Quaternary cover.

The extraction and analysis of the geometry and density distribution of the geological lineaments in this study were executed using both PCI Geomtica and ArcGIS (ArcMap) software packages (Fig. 2.8 b \& c). ArcScene application was used for draping extracted structural lineaments on DEMs and terrain models to visualize the mapped sectors along the $\mathrm{RN}$ in 3D perspective views (Fig. 2.8 a). After several trials and change of the parameters applied here, the complementary statistical analysis and visual interpretations were also useful to check the reliability of using these datasets in the semi-automated extraction of structural lineaments. Different tools in ArcMap and ArcGIS Pro were applied to enhance and edit the extracted lineaments to exclude the false detections and to improve those might represent evident structural elements.

The main objective here is to show the advantage of using alternative applications of remote sensing techniques in structural mapping. Hundreds of lineaments were extracted here using the same parameters for all datasets of along the proposed rift of the Nile Valley. These frequently represent rift-related structures such as faults, linear alignments of folds and volcanic intrusions, structurally controlled drainage tributaries, and fractures, all have dominant rift-parallel trends of NW to NNW direction in addition to fewer cross-trends (riftorthogonal segments) of E-W and ENE strikes (Fig. 2.8 c). Most of the extracted lineaments are consistent in density and orientation with the manually interpreted and mapped faults, folds and fractures in both fieldwork and using ArcGIS mapping toolsets. All show reliability with the regional extensional tectonics and structural setting of the Nile Valley area as well as the geometry of different segments of the proposed rift.

Statistical algorithms were applied to analyse the distribution density and different trends of the extracted structural lineaments. Bi-directional rose diagrams and density maps were used here to display the results of the lineament analysis. This aims to understand the geometry, orientation and spatial arrangements of the tectonic features along the eastern and western shoulders of the proposed rift along the Nile Valley. The geological lineaments are mainly concentrated in regions that show large grayscale level transformations around active faults, 
while the grayscale levels in the flat areas were almost unchanged. Areas with good lithological bedrock exposure also showed a high density of lineaments, but the area of the fault showed average-density lineaments. After field geological and geomorphological investigation, the geologic lineaments extracted automatically using this algorithm were found to be in good agreement with the existing landforms.

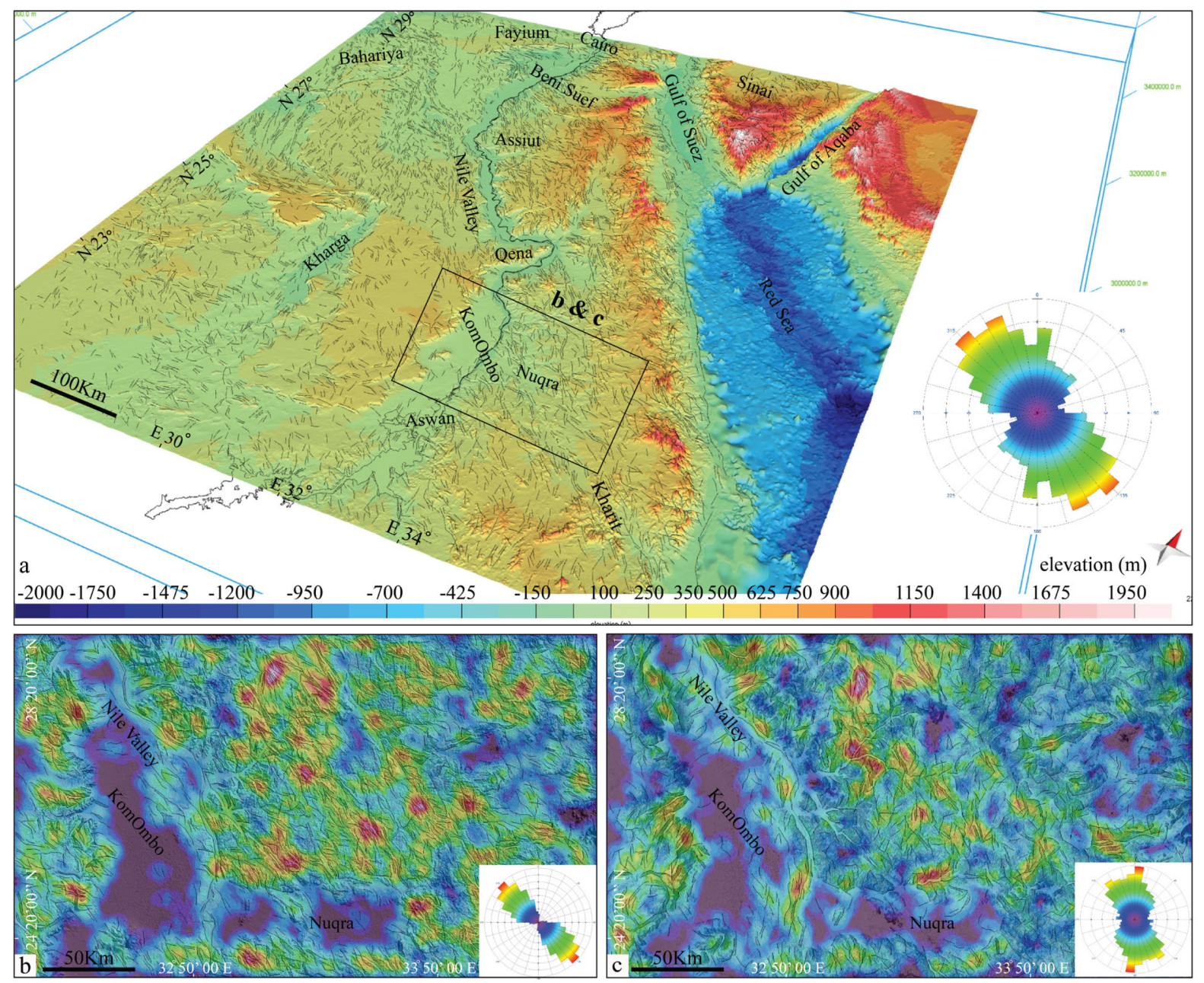

Fig. 2.8. Extracted structural lineament of the River Nile and Gulf of Suez-Red Sea Rift Systems. The inset rose diagrams show the strike orientations of the surface structural lineaments and Precambrian Basement tectonic fabrics with dominant NW, $N N W$ and NNE trends. b) Extracted lineaments of the southern Nile rift segment using traditional Hillshade model with sun angle perpendicular to the predominant $N W$ orientation (see the inset rose diagram). c) Extracted lineaments using multidirectional Hillshade model that helps to recognize the different structural trends of the same area such as the N-S and $N E$ strike orientations (see the inset rose diagram). The red, green and blue colors of figures $b \& c$ show high, intermediate and low densities of the extracted lineaments, respectively. The eastern shoulders of the southern Nile rift segment are characterized by relatively higher densities of the extracted lineaments.

Using the same input parameters for automated lineaments extraction, statistical analysis revealed that datasets of different horizontal resolutions produce lineaments with significant differences in both their frequency and distribution densities. The high-resolution DEMs and satellite images $(10,12.5 \mathrm{~m})$ that are used here resulted in highest frequency and population 
density of the extracted lineaments, while data of moderate resolution $(20 \& 30 \mathrm{~m})$ produced comparatively moderate frequency. The relatively lowest resolution DEMs (90 \& $225 \mathrm{~m}$ ), on the other hand, resulted in the minimum frequency of the extracted lineaments that represent the large-scale structural elements and tectonic fabrics such as major faults, fold belts, extensive fractures and shear zones. This shows a close resemblance to the conclusion of Qari (2011). The results of our work show also that the terrain models that can be produced by processing of DEMs such as Slope, Hillshade and Aspect are more consistent for use in the extraction of structural lineaments.

In summary, both mountain hillshading algorithms (traditional and multidirectional) could be effectively used as a background to provide the values of slope and aspect for efficient semiautomated extraction of structural lineaments. Additionally, single-band grey scale or RGB composite images based on results of principal components analysis (PCA) of optical satellite data can serve as useful background for extraction of structural lineaments. As indicated earlier, PC bands help to reduce noise and data redundancy of the original satellite images and highlight the differences in hue and saturation values of pixels, which in turn decrease the noise and redundancy of extracted lineaments.

\subsubsection{Drainage Analysis}

A drainage basin is an area that drains water and other substances to a common outlet (ESRI, 2020). Other expressions are commonly used to describe the drainage basins such as catchment, watershed, or contributing area. A growing number of algorithms and toolsets are now provided in the hydrogeology toolbox of software packages for automatic extraction and calculations of various hydrogeologic parameters using data from elevation surfaces (DEMs). The hydrology tools focus on the movement of water across an elevation surface. Several toolsets available in ArcGIS were used to extract stream networks, flow directions, basins and watersheds of the Nile's drainage system at both regional and local scales (Fig. 2.9; see also Fig. 1.2 \& Fig. 1.4 c). These parameters were computed on DEM surfaces of different horizontal resolutions. Recent developments in GIS computations make it easier and faster to define the hydrogeological characteristics of the drainage system of an area by using data from an elevation surface or DEM as an input raster into automated algorithm calculations. 
The extraction of drainage networks has been investigated by many studies that combine the calculations of different functions, for instance, the slope, aspect and curvature of neighbouring pixels (cells) in an elevation raster or DEM. This is to establish the possible flow direction and amount of accumulation of water across an area, by defining connectivity between drainage channels and to construct catchments and flow networks (Liu and Mason, 2016). The drainage area is commonly defined as the total area flowing to a given outlet, or pour point at which usually represents the lowest point in the drainage basin.
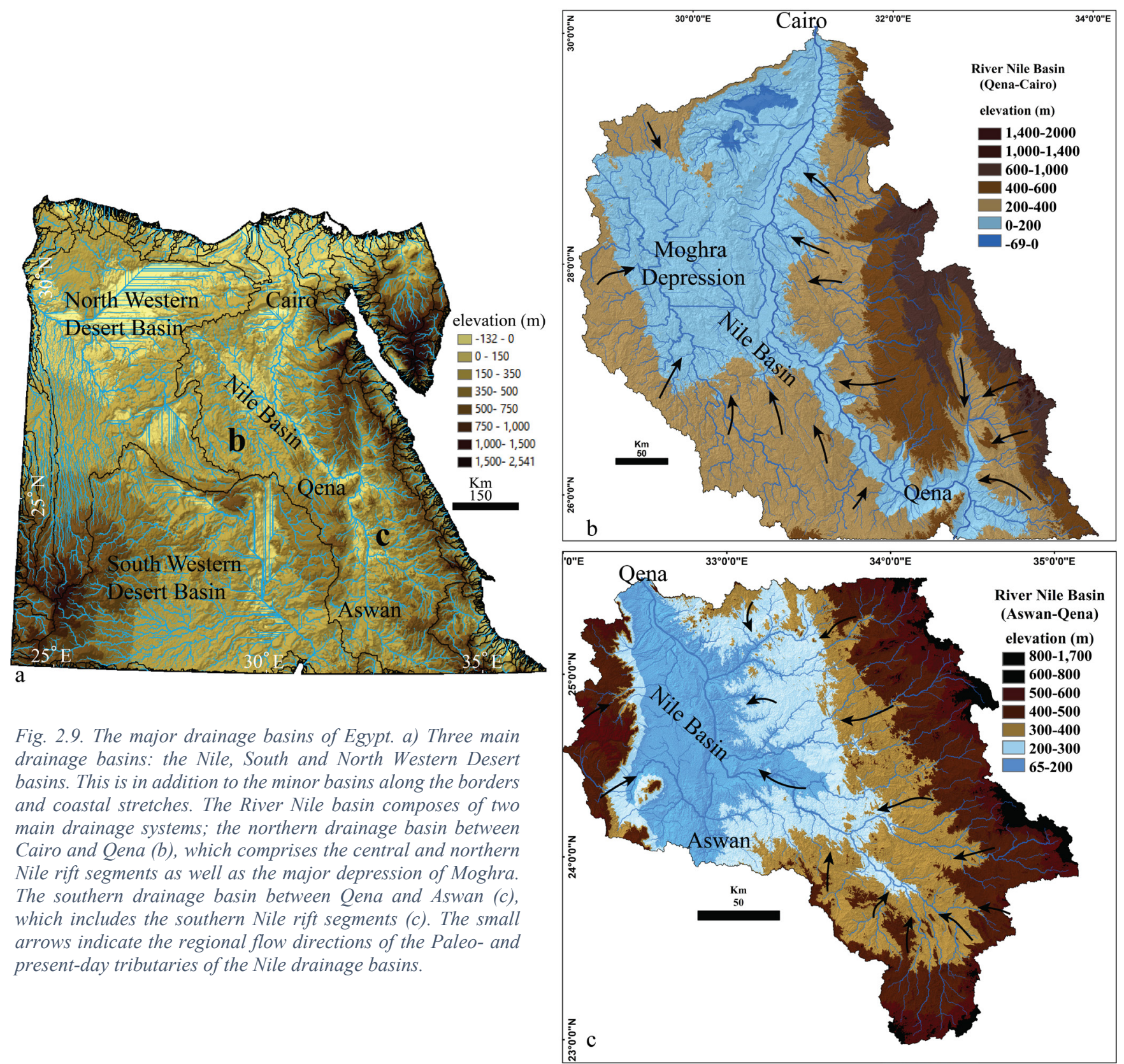

Fig. 2.9. The major drainage basins of Egypt. a) Three main drainage basins: the Nile, South and North Western Desert basins. This is in addition to the minor basins along the borders and coastal stretches. The River Nile basin composes of two main drainage systems; the northern drainage basin between Cairo and Qena (b), which comprises the central and northern Nile rift segments as well as the major depression of Moghra. The southern drainage basin between Qena and Aswan (c), which includes the southern Nile rift segments (c). The small arrows indicate the regional flow directions of the Paleo- and present-day tributaries of the Nile drainage basins. 
Most of the DEMs contain artefacts such as sinks that cause problems during the automated algorithm computations. Therefore, the sinks must be filled to create a "depressionless" DEM surface using the "Fill" tool in ArcGIS hydrogeology toolbox. The "filled" DEM surface is used then to calculate the flow direction and accumulation. The flow direction function creates a raster of flow direction from each pixel to its downslope neighbour, or neighbours, while the flow accumulation function creates a raster of weighted accumulated flow into each pixel. Using the DEM raster as input, it is possible to calculate the flow direction function, which is necessary to compute other parameters such as flow accumulation, stream network and order, drainage basins and watersheds (ESRI, 2020).

The present study used the 'Model Builder' tool in the ArcGIS-Toolbox to derive the drainage network of the Nile basin. The automated computation algorithms were performed by applying the surface flow routing based on the 8D flow direction (Jenson and Domingue, 1988). This step was followed by the derivation of the surface flow accumulation, which was used to delineate the channel network of the basin by applying a threshold of 1000, 2000 and 5000 cells based on the horizontal resolution and surface area of the imported DEM raster. The drainage network system of the Nile basin in Africa and Egypt as well as some selected regions of interest along the river were extracted here.

Most of the extracted drainage networks of the RN basin are structurally controlled and run parallel to faults reveal that Egypt was drained by several paleo-streams that currently represent dry valleys and wadies in the Eastern and Western Desserts (Fig. 2.9). The boundaries of the extracted Nile's drainage basin delineate the margins of the proposed rift with a regional NW to NNW trend. Many of the extracted channels may represent paleo-drainages of the Ancestral Nile (Fig. 2.9 b \& c).

\subsection{Field Work}

Many fieldwork seasons were conducted along the eastern and western sides of the central and northern sectors of the Nile Valley where we tried to map and measure some stratigraphic units, morphotectonic features and structural elements such as rift-related faults, folds and volcanic intrusions in the study area (see Fig. 1.1). 
Of a particular importance to the structural model of the proposed rift, the "syn-rift" Oligocene clastics that are distributed in the east and west of the Nile valley were also studied. We emphasised our geological field mapping on the western parts of Fayium, Beni Suef, Assiut and East Minia. During these excursions, the main stratigraphic units and different spectacular structures of the southern and western parts of the study area were investigated in addition to measuring the orientations of significant structural elements (fractures, faults and dips of different strata). We also collected 26 basalt rock samples from 14 sites around the Nile Valley to use them for ICP-MS Geochemical analysis, petrographic investigations and absolute age dating (K-Ar).

\subsection{Subsurface Imaging}

The calibration, analysis and interpretation of high-resolution gravity and magnetic datasets provides a crucial tool for the subsurface imaging of different crustal structures and tectonic fabrics that characterize the Precambrian basement complexes and overlying rift basins. This is also useful for the 3D modelling of the structural architecture of rift basins, fold-fault belts, ridges and tectonically inverted topographies of the stratigraphic mega-sequences. Various gravity and magnetic anomaly models covering the entire area along the Nile Valley, with different resolutions (from $2 \mathrm{~km}$ to $200 \mathrm{~m}$ ), were analysed and interpreted.

Interpretation of inadequate $2 \mathrm{D}$ and $3 \mathrm{D}$ seismic surveys scattered along the $\mathrm{RN}$ was yet quite valuable to image and model the subsurface structures of the inherited Mesozoic basins along the river valley and their possible effects on the tectonic evolution of the proposed LatePaleogene Nile rift. The present study used data from 2 (3D) seismic cubes and 17 oil wells in West Beni Suef area (West of the Nile) together with 2D seismic profiles, data from five boreholes and gravity and magnetic anomaly measurements in Assiut Basin (East of the Nile). In addition, some information form borehole data and interpreted seismic profiles were integrated here, which were included in previous relevant literature as well as in some petroleum internal reports, particularly in the southern Mesozoic rift basins (Fig. 2.10). 


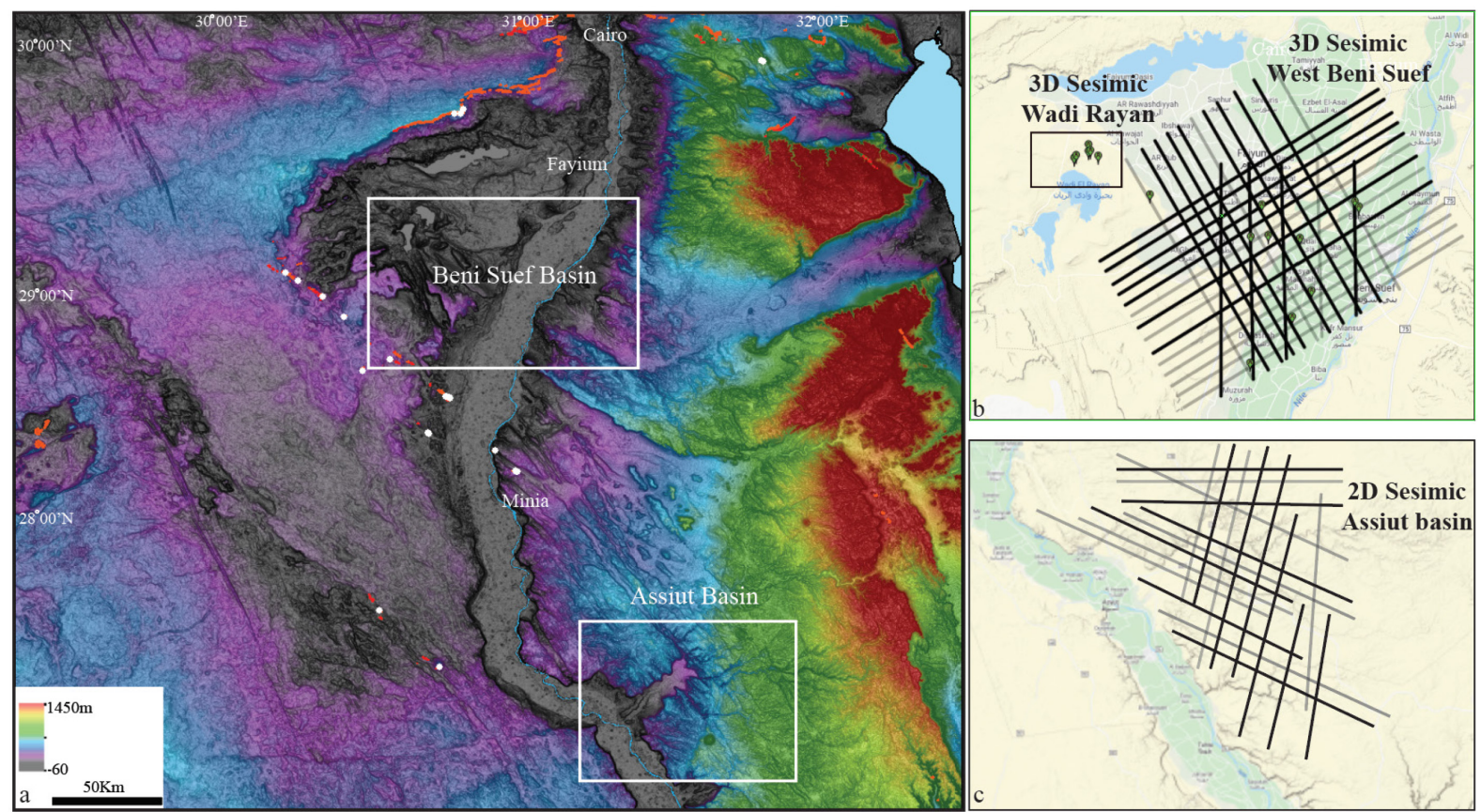

Fig. 2.10. Location map for the 2D and 3D seismic and gravity data used in this study. a) Locations of Assiut and Beni Suef basins. It also shows the locations of 26 basalt samples were collected for age-dating (white circles). b) 3D seismic surveys in Beni Suef basin. c) 2D seismic survey in Assiut basin (Wadi Mahareith concession).

This study has also utilized images form 3D subsurface maps that are identified as "Structurally Enhanced view of Economic Basement" (SEEBASE). These subsurface maps were integrated and interpreted by Steffan et al. (2000) as a part of Egypt's Area Regional Study (EARS) that generated a 3D view of the basins and petroleum systems of Egypt (Fig. 2.11). The EARS report was conducted by SRK Consulting Australasia based on systematic calibration, integration and interpretation of both seismic and non-seismic datasets (gravity, magnetic, and well data) from multi-temporal studies on Egypt's basins. The results were published in some literatures such as Loutit et al. (2001) and Dolson et al. $(2005 ; 2014 ; 2020)$. The depth to the basement was compiled from modelled magnetic depth to basement estimates using both automated programs and profiles across selected anomalies (Steffan et al., 2000). These estimates were then attributed to top basement or deep crustal sources. The final contouring of "top basement" estimates was controlled by the principal basement-involved faults identified through the interpretation of magnetic, gravity, DEM, Landsat and seismic data.

The depth to basement interpretation (SEEBASE) was calibrated by: the application of realistic basement rock properties in magnetic modelling established during the calibration phase, basement depths established by well intersections, consistency with well depths and examination of selected regional seismic data. These maps display 3D perspective images of 
the depth to economic basement, and illustrate the distribution, architecture and relative depths and of rift basins and uplifted ridges. These subsurface maps were utilized in the current work help to characterize different Precambrian basement structures, major shear zones and morphotectonic fabrics, and to identify the geometry, structural architecture, and distribution of the Mesozoic and younger rift segments, sub-basins, and transfer zones in southern and central Egypt, particularly along the Nile Valley (Fig. 2.11). 


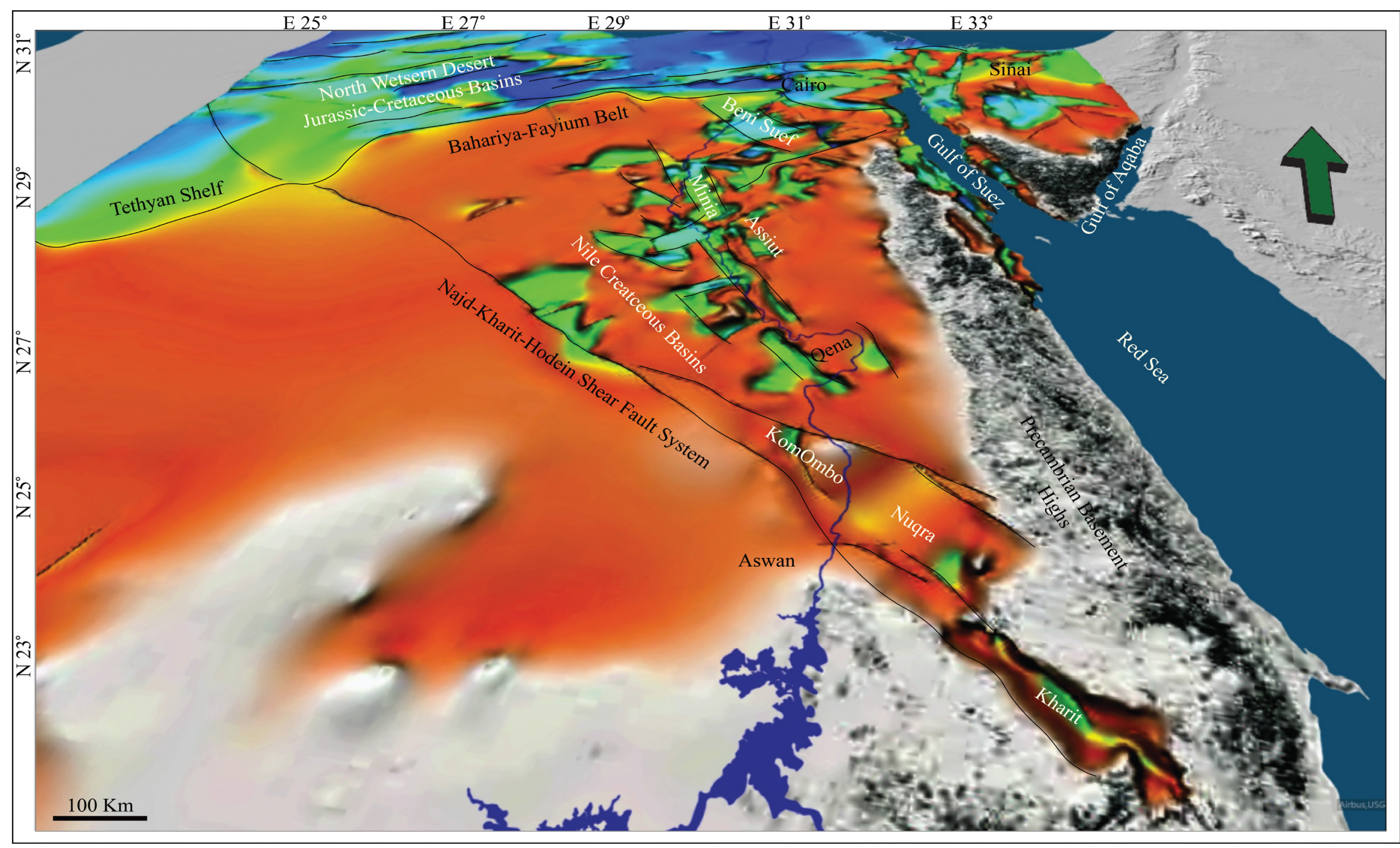

Fig. 2.11. SEEBASE shaded basement relief map of Egypt showing the main rift basins of Egypt. Three main groups of these rift basins are: 1) North Western Desert Jurassic and Cretaceous basins with E-W, ENE and NE orientations. 2) Cretaceous and Late Paleogene-Early Neogene Nile rift basins such as, from south to north, Kharit, Nuqra, KomOmbo, Central Nile, Assiut and Beni Suef basins; all are of NW to NNW orientation. 3) NNW-oriented Red Sea-Gulf of Suez Oligocene Rift System in the east. The main structural belts and shear zones are shown in black lines. Data from Steffan et al. (2000). 


\subsubsection{Interpretation of Gravity Models}

High-resolution regional gravity field models provide a vital contribution to geophysical, tectonic and geodynamic applications such as structural and tectonic modelling of the crustal and lithospheric densities and thicknesses (Sampietro et al., 2018). The high-resolution gravity anomaly models can be estimated from terrestrial gravity measurements of short wavelength, which are not always available with a suitable coverage density, while the global geopotential models derived from satellite observations/measurements can only provide long-wavelength signal with wide-area coverage (Sobh et al., 2019). Several gravity field models and anomaly maps covering different regions in Egypt were combined and developed by various studies through the integration of satellite and terrestrial measurements and computations (Fig. 2.12).
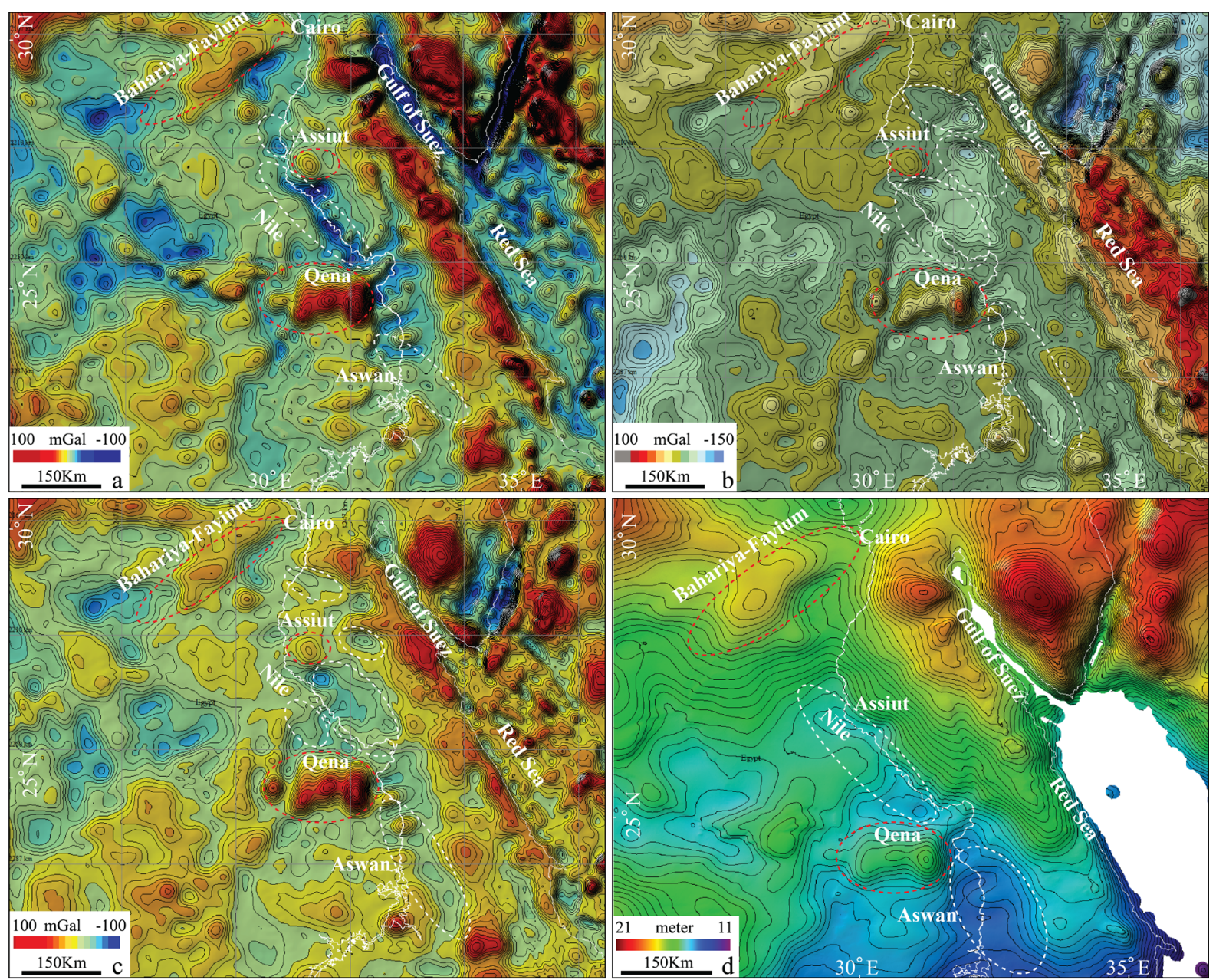

Fig. 2.12. Regional gravity models over Egypt using data from WGM2012 (Bonvalot et al., 2012). a) Free-Air gravity anomalies reduced by the topographic effect. b) Bouguer gravity anomalies. c) Isostatic gravity anomalies. The three models show clear negative gravity anomalies beneath and around the proposed southern, central and northern rift segments along the River Nile (white-dotted ellipses) as well as the rift-oblique and rift-orthogonal transfer zones such as the prominent basement high of the Qena-bend zone, and the northern termination belt between Bahariya and Cairo (Bahariya-Fayium belt), both are characterized by conspicuous positive gravity anomalies (red-dotted ellipses). d) Geoid anomaly model showing the regional negative anomaly model along the River Nile, data from Hirt et al. (2013). 
Different datasets form the World Gravity Map (WGM2012) were integrated in this study. The gravity measurements were computed and complied by Bonvalot et al. (2012). The datasets include a set of three anomaly maps; the terrestrial surface Free-Air (FA), complete Bouguer and Isostatic gravity anomalies (Fig. 2.12 a-c). The current work has also used gravity data measurements of Hirt et al. (2013) that provide a high-resolution image of the global Earth's gravity ( $\sim 200 \mathrm{~m}$ spatial resolution) using GOCE/GRACE satellite and terrestrial gravity measurements integrated with topographic gravity in addition to massive parallel computation techniques (e.g. Fig. 2.12 d).

The WGM2012 provides information on the Earth's gravity field at regional scales. The gravity information was derived from the Earth Geopotential Model (EGM2008) that includes surface gravity measurements from land, marine and airborne surveys integrated with satellite altimetry and gravimetry data. Gravity anomalies are used to investigate the mass-density distribution of the Earth's interior to provide constraints on the geological structures from the subsurface, crustal to upper mantle depths (Balmino et al., 2012). This helps to characterize the locations and geometry of rift basins and subsurface morphotectonic highs and lows of the Precambrian basement complexes that are directly responsible for the variations of massdensity distribution, which in turn cause anomalies of different gravity field measurements.

\subsubsection{Interpretation of Magnetic Models}

Magnetic anomaly models improve our knowledge of subsurface structures and tectonic features as well as the variable composition of the Earth's lithospheric crust. Magnetic anomalies result from geologic structures, large-scale volcanism, basement heterogeneities and crustal thickness variations that increase or reduce the local magnetic field. The Earth Magnetic Anomaly Grid-2-arc-minute resolution (EMAG2v3) was used here. This was integrated and compiled by Meyer et al. (2017) using satellite, ship, and airborne magnetic measurements (Fig. 2.13). The relatively high-resolution magnetic anomaly models in addition to the 3D SEEBASE maps revealed structures and crustal thickness variations suggesting several rift basins occur beneath and around the modern Nile Valley (Fig. 2.11 \& Fig. 2.13).

The structures of the Precambrian basement terrain appear to control the architecture of the rift basins along the RN. The magnetic map of Egypt was a helpful tool to recognize the regional 
architecture of the sedimentary basins and basements highs at a large scale (Fig. 2.13). However, the scale was not fine enough to detect the effect of the rift-related volcanism on the distribution of the magnetic anomalies particularly along the proposed Nile rift. Although the study of the subsurface volcanic occurrences in the rift segments along the Nile was not possible at the used map-scale, the distribution of the magnetic anomalies shows the concentration of the volcanics along the major rift basins and shoulders. The magnetic anomaly map was useful to understand the basement morphology underneath the proposed rift along the Nile Valley as well as to characterize different rift segments, sub-basins, and mega fault-fold belts, and transfer zones (Fig. 2.11 \& Fig. 2.13). 
Fig. 2.13. Magnetic anomaly over Egypt showing the structural morphology of the Precambrian Basement, the major tectonic fabrics and distribution of the sedimentary rift basins. It indicates the regional distribution, geometry and architecture of sedimentary rift basins along the River Nile (e.g. Kharit, Nuqra, KomOmbo, Assiut, wadi Assiuty, Beni Suef and Moghra depression) addition to the North Western Desert NE-trending basins. These rift basins show conspicuous negative anomalies due to the thick accumulation of sediments as well as the thinned crust and deep Basement levels. While, on the other hand, the raised rift shoulders and uplifted Basement regions showstriking positive anomalies. Examples are the Basement highs of the southern Nile rift shoulders, Sin El-Kadab Plateau, Qena bend transfer zone, Sohag High, and the NE-oriented rifttermination belt of the BahariyaFavium fold-fault structures and Kattaniya Highs. Data from EMAG2v3 (Meyer et al., 2017).

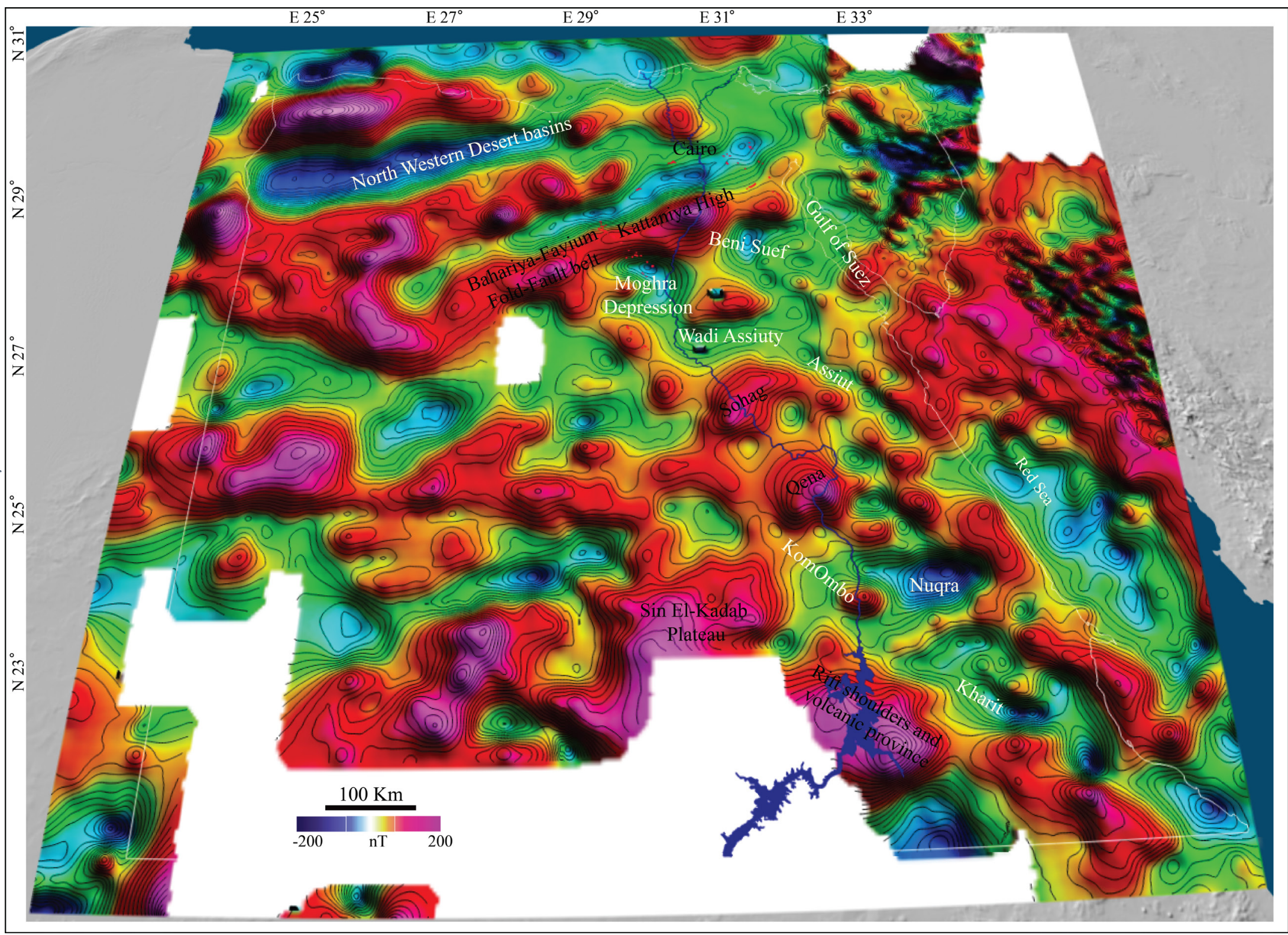


Chapter 3 Evolution of the River Nile 


\section{Introduction}

The longitudinal and transverse profiles of drainage systems reveal the role of different tectonic settings and drainage basin lithology on the evolution of rivers through space and time. Geological structures and lithological variations usually control the basic physical properties of the river systems. The Nile has carved its way through major topographic swells with six main cataracts crossing its course, one in southern Egypt at Aswan and five in Sudan (Fig. 3.1). For many years, several studies have emerged with diverse ideas proposed on possible origin(s) and age(s) of the Nile and its drainage systems. These vary between the tectonic and nontectonic genesis of the river (Erosion/incision models vs uplifting/rifting models) in addition to recent approaches about the possible controls of Mantle plume-related upwellings and dynamic topography on the development of the Nile River. However, there is still a crucial need to understand the role of extensional tectonics and intracontinental rifting processes on the multistage development and segmentation of the ancestral and present-day River Nile (RN) systems and their drainage basin(s) and valley(s). The regional profile of Nile displays a combination of different segments with different evolution history (Fig. 3.1).

The transcontinental great river systems are either relatively young or fundamentally related to compressional tectonics, orogenic belts, and exhumation processes that form the upstream high plateaux (e.g. Amazon, Ganges, Indus and Tigris-Euphrates) (Tandon and Sinha, 2007; Gupta et al., 2020). Great rivers systems are also generated by the gradual uplift of a continental interior (e.g. Mississippi-Missouri) (Gupta, 2007; Tandon and Sinha, 2007; Underwood et al., 2013; Abdelsalam, 2018). Africa is characterized by passive rather than active plate margins, and by a dominance of basins, faults and rifts rather than compressional tectonic features (Sestini, 1984; Klitzsch, 1986; Wit, 2003; Fairhead et al., 2013) (Fig. 3.1; see Fig. 1.2). The intraplate topographic highs/swells and the successively formed drainage systems (e.g. RN) in such tectonic settings are commonly formed by a regional uplifting that is rolled by uprising Mantle plumes (Ethiopian "Afar" and Kenyan plumes) rather than due to exhumation produced by mountains-building compressional tectonics. This intraplate uplifting is usually followed by intrusion of huge igneous bodies prior to intracontinental rifting and dominance of extensional tectonics that consecutively control the structural architecture and distribution patterns of the developed drainage systems as well as the orientation of their stream courses. 


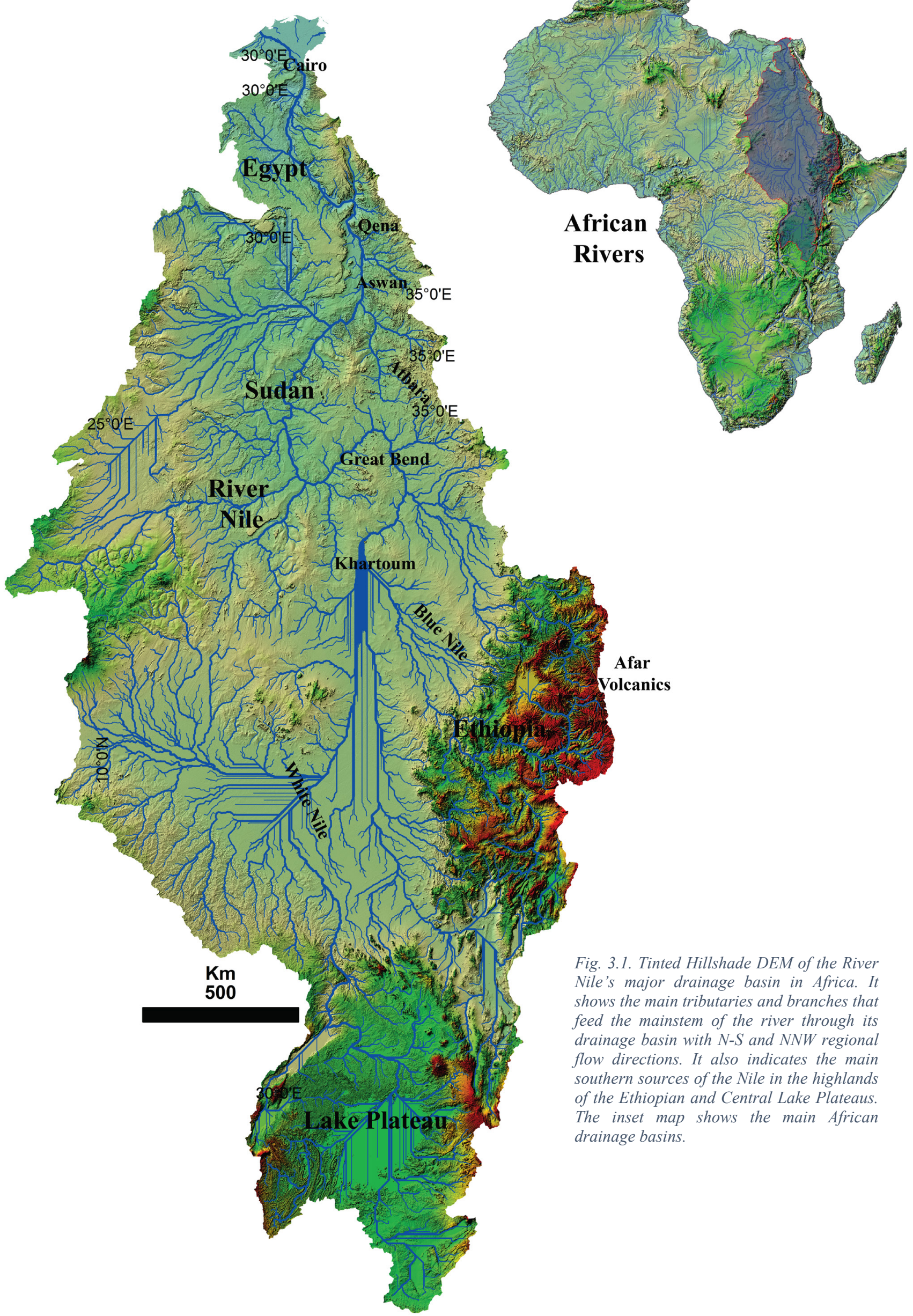


Many of the African rivers have a range of intriguing characteristics that indicate complex history including shifts in the nature of their catchments and courses, particularly since the splitting of Gondwanaland that has begun in the Early Cretaceous (Goudie, 2005; Gupta et al., 2020) (Fig. 3.1). The drainage system of large rivers and their evolution over long time can also be sustained for a long time by a dynamic topographic gradient (Faccenna et al., 2019). The southeastern drainage systems of the Nile have been formed since $\sim 31-28$ Ma by a regional tectonic uplift that was rolled by mantle plume activities, intrusion of the huge Ethiopian volcanism and development of the East African-Red Sea rift system (Abdelsalam, 2018; Faccenna et al., 2019). The physical properties, evolution and connectivity of rivers depend on their structural framework, geological history and environmental fluctuations that shape and modify their drainage basins over space and time as the result of tectonic and climate changes. Consequently, the morphology of the drainage systems of most rivers changes temporally along their courses.

In terms of possible origins and initiation time, the evolution of the $\mathrm{RN}$ has been widely studied through two main controversial hypotheses. Many studies support the idea arguing that the RN has probably sustained a continuous or intermittent flow since the Late Eocene-Oligocene time until its present-day shape (Berry and Whiteman, 1968;Williams and Williams, 1982; Williams, 2009; Abdelkareem et al., 2012; Underwood et al., 2013; Abdelkareem and El-Baz, 2016; Faccenna et al., 2019). The drainage systems of the river might have also sustained continuous pathways from its southern sources in the exhuming highlands of the Ethiopian Plateau into the northern lowlands of Sudan and Egypt (Fig. 3.1; see Fig. 1.2).

The second hypothesis claims that the connection between the Ethiopian tributaries and the Nile canyon in Egypt, which formed the present-day shape of the river drainage system with dominant northward flows into the Mediterranean Sea, has possibly occurred only during the Late Miocene-Pliocene time. This has occurred most probably following the Messinian salinity crisis at $\sim 6-5 \mathrm{Ma}$, or even later in the Pleistocene time $\sim 2.5 \mathrm{Ma}$ (Issawi and McCauley, 1992, 1993; Stern and Abdelsalam, 1996; Talbot and Williams, 2009; Abdelsalam, 2018). Large rivers such as the Nile or Indus have been associated with human civilization for thousands of years and show expected modifications, while over approximately the last 100 years, many 
rivers have been modified by engineering structures such as dams and reservoirs (Gupta et al., 2020).

Our observations, analysis, and interpretation of the integrated surface and subsurface datasets along the river course support the tectonic origin of the Nile Valley in Egypt, particularly the intracontinental rifting processes, accompanying regional uplifting, volcanism and extensional deformation. This work suggests that most of the studied Nile-parallel faults, folds, fractures and grabens on both shoulders of the valley, essentially those of NNW and NW strike orientations, were either activated or reactivated along pre-existing structures and tectonic fabrics of Precambrian and Cretaceous ages. These extensional tectonic movements occurred contemporaneously with the initiation of a Late Paleogene-Early Neogene rifting phase in NW to NNW direction along the Nile Valley in central and southern Egypt.

The onset of the main rifting phase in the Nile area and evolution of the initial drainage system of the ancestral river(s) was contemporaneous with the initiation of the Red Sea-Gulf of Suez rifting in the Oligocene $\sim 28-25 \mathrm{Ma}$ in Eastern Egypt. The proposed Oligocene rifting along the Nile has probably been aborted at a very early stage. The Neogene drainage systems and the ancestral river and shallow rift valleys $(\sim 25$ to $\sim 6 \mathrm{Ma})$ were possibly incised along some faultbounded troughs, shallow linear grabens, fractures and faults that were formed during the shortlived phase of the proposed rift (Fig. 3.2 \& Fig. 3.3). This was followed by the subsequent carving of the deep "Eonile" Canyon during the Messinian Salinity Crisis and drying out of the Mediterranean Sea ( 6-5 Ma, see Fig. 3.3) (Said, 1981). In the following, we summarize a review of some geologic literature and suggested ideas on the development history, possible origins and ages of the Nile and its drainage systems, in addition to our proposal that focuses mainly on the tectonic evolution of the Egyptian part of the river.

\subsection{Possible Origin(s) of the Nile}

In general, the tectonic movements together with subsequent geomorphic processes determine the required development of the rivers drainage basin topography that is marked by elevated boundaries and a regional slope (Gupta et al., 2020). Mantle plume-related geodynamics and continental plate tectonics control the architecture of the river basin and its drainage system. Although the Nile has been receiving the attention of many authors since the early years of the 
last century and to date, its origin and initiation time are still poorly understood with a considerable controversy surrounding the possible geodynamic, tectonic and hydrogeological controls. The connection between the development of the river and the Late Eocene-Early Oligocene regional uplift, and the subsequent onset of the Red Sea-Gulf of Suez continental rifting has not been well established yet.

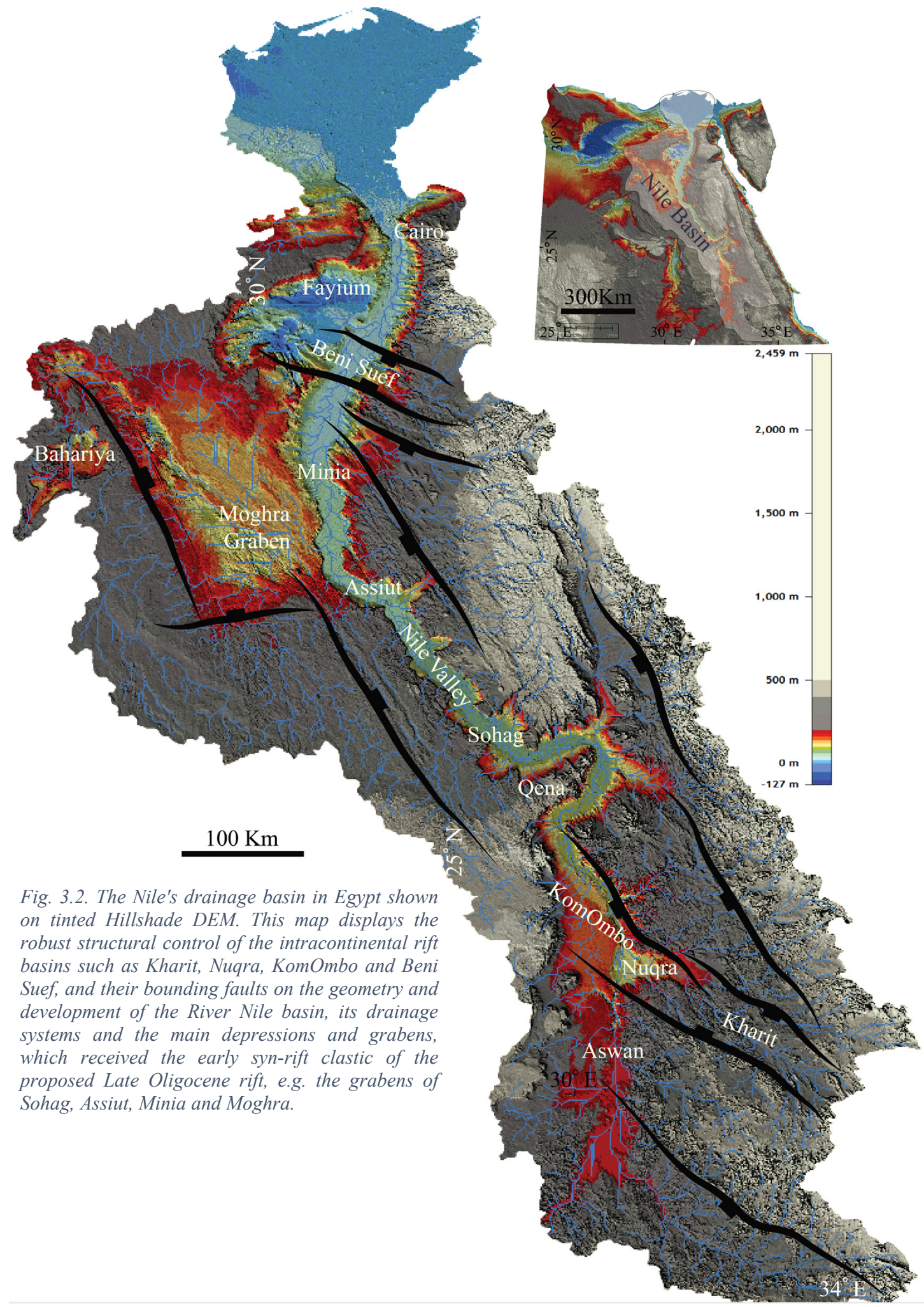




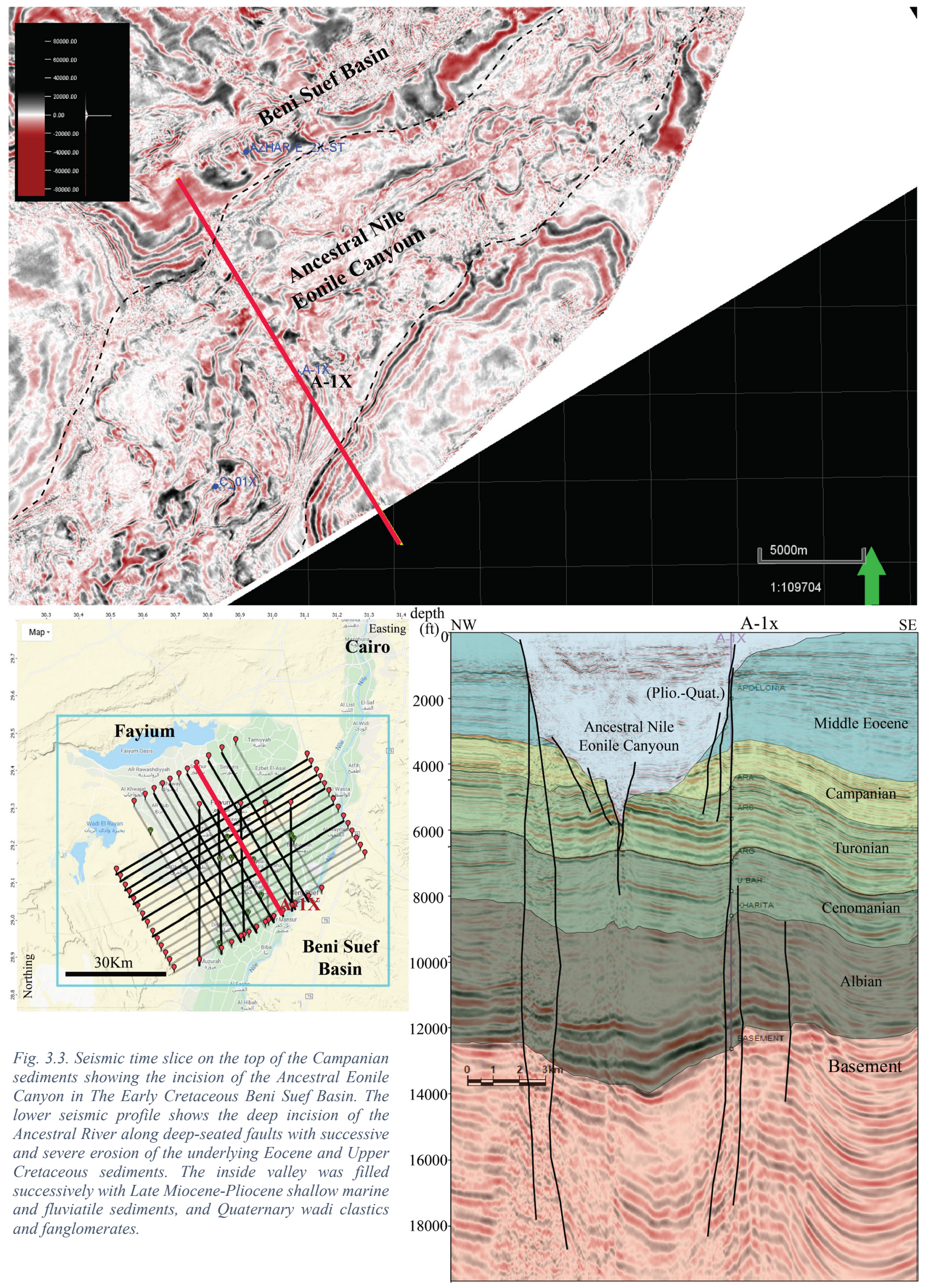


Some preliminary studies were carried out in the early 1900s and suggested that the Egyptian Nile was formed by extensive erosion along a broad syncline of N-S orientation (Beadnell, 1900; Ball, 1909; Hume, 1910; 1929). While others believed that the course of the river was probably originated by faulting along shallow troughs (Suess, 1904; Lawson, 1927; among others). Their hypothesis was based on some observations along the Nile Valley including the NW orientation of the river (i.e. parallel to the Gulf of Suez rift system), steep scarps with absence of high-river terraces, and fault occurrences that delineate the Nile-bounding cliffs (Fig. 3.4, see also Fig. 1.3, Fig. 1.5 \& Fig. 1.7). Sandford (1928, 1929), on the other hand, reported that most of these faults are oriented obliquely to the river, and was not formed by rifting but rather due to slumping of the hard-Eocene limestone blocks above the underlying soft Esna shales. This idea was also supported by Ball (1909); Hume (1910) and Sandford (1934).

According to Said $(1962,1981)$, the Nile was probably eroded along a line of faulting and rifting. He found few pieces of evidences supporting this approach based on interpretation of shallow-drilling hydrological data and exposed fault scarps, which might prove that the northern part of the Nile Valley near Cairo occupies a line of a "post-Middle Pliocene" fault in an indication of possible rifting as an origin of the river. While further to the south, near Minia, the basalt intrusions along inferred faults of possible Oligocene age might have controlled the course of the Nile Valley.

A different hypothesis was suggested by Youssef (1968) for the origin of the Nile valley, Gulf of Suez, and the Gulf of Aqaba. He considered them as structural grabens or rift valleys that were formed by horizontal displacements along wrench (strike-slip) faults with minor components of vertical displacement, which was probably initiated much later along weak faults when large sections of the region were up-warped. These faults were originally developed along two complementary shear fractures that were activated as the consequence of horizontal crustal compressive stresses, directed $\mathrm{N} 10^{\circ} \mathrm{W}-\mathrm{S} 10^{\circ} \mathrm{E}$, acted on the entire region for a considerable period with a later slight $\left(10^{\circ}\right)$ anticlockwise rotation, which produced the N-S trends. The main vertical displacements that formed the grabens of the Nile Valley before the Pliocene time, based on his interpretation, were caused by lateral stretching of the up-arched region and down faulting with denudation along initial lines of weaknesses. A dextral 
movement along NW-SE faults was also suggested by (Akawy and El Din, 2006) as the main structural control on the course of the Nile Valley, which was subsequently modified by a dextral movement along N-S faults and later by dextral shears running in NE-SW direction. The strike-slip movements on these fault trends have changed to normal dip-slip components prior to the Pliocene time.

Relatively recent to what is mentioned above, some previous studies also believe that the $\mathrm{RN}$ is structurally-controlled while its course was strongly influenced by parallel and oblique structural features (Said, 1981, 1990b; Adamson and Williams, 1982; Adamson et al., 1993; Youssef, 2003; Issawi et al., 2008; Seif, 2015; Abdelsalam, 2018; this work, see Fig. 3.3, Fig. 3.4, Fig. 2.7c \& Fig. 2.11). Adamson et al. (1993) proposed that the formation of the northerlyflowing RN and its drainage system was associated with the development of the East African Rift System and the breakup of the Afro-Arabian plates during the Oligocene time. It was also suggested that the graben-like channel of the Nile Valley was formed along faults that were formed contemporaneously with the onset of the Red Sea-Gulf of Suez rifting (Said, 1981, 1993). Youssef (2003) interpreted the NW-SE trend of the central part of the Nile Valley to compressive stresses accompanied the extensional phases of the Red Sea-Gulf of Suez rift system. To the south in Sudan, the Late Jurassic rifting was best documented in the White and Blue Nile rifts that have been rejuvenated as the result of NE-SW extension in the Late Paleogene and Neogene (Bosworth, 1992). These rifts represent the grabens and troughs that hosted many branches of the RN in Sudan.

The RN formed through subsequent phases and lengthened during the northward drift of Africa relative to the Equator that was probably located at the present-day latitudes of Chad and Sudan with dominating pluvial conditions in the Late Eocene or Oligocene time (Abdelkareem et al., 2012). The gradual northward drift of Africa through space and time might have shifted the upstream sources, and consequently new valleys and drainage systems were formed in different locations associated with an increase of the length of the Nile's mainstem while the ancestral river segments were abandoned. Abdelkareem and El-Baz (2016) claimed that the current course of the Egyptian Nile was probably caused by a differential uplift of the eastern and western plateaux of the valley, which was in turn initiated by dynamic forces rolled by Mantle convection processes. 


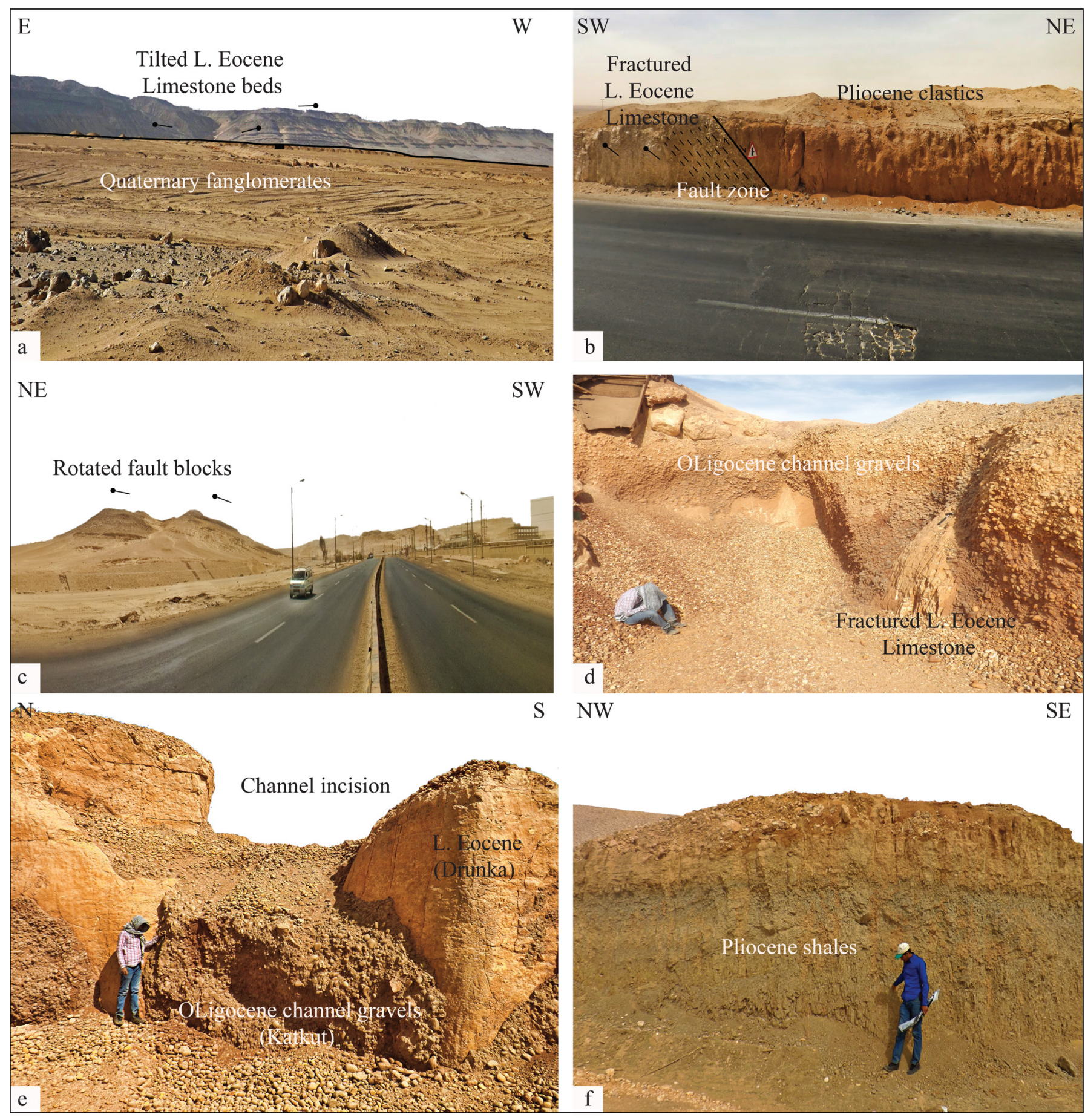

Fig. 3.4. Extensional faults, cliffs and fault blocks along the shoulders of the Nile Valley. a) E-W-oriented faults along Wadi Assiuty cliffs and titled Lower Eocene Thebes Limestones, east of the Nile, Assiut. b) NW-striking faults forming grabens that were filled with Pliocene sediments along the western shoulders of the Nile Valley, Assiut-Sohag district. c) Rotated and tilted Lower Eocene (Drunka) Limestone fault blocks along NW-oriented faults that bound the eastern cliffs of the River Nile, Assiut. d) Accumulation of Syn-rifting Oligocene gravels and red sandstones in fault-bounded grabens and fractured Lower Eocene Drunka carbonates. e) Oligocene channel incisions along NNW-oriented faults and fractures parallel to the main course of the Nile. f) NW-striking fault scarp with accumulation of fluviatile Pliocene shales and siltstones. 
More recent hypotheses pointed out possible controls of the Cenozoic dynamic topography on the development of the entire RN and its drainage systems in Africa and Egypt (Abdelsalam, 2018; Faccenna et al., 2019, see Fig. 3.2). According to Faccenna et al. (2019), a large mantle convection cell beneath the Nile region has controlled the topography over the last $\sim 30$ million years, inducing a regional uplift in the river upstream in the Ethiopian-Yemen Dome, and subsidence in the downstream in northern Egypt and the eastern Mediterranean basin. In his review article on the Nile's journey through space and time in Africa, Abdelsalam (2018) indicated that the evolution of the initial drainage systems in the two upstream sources of the RN (the Northwestern Ethiopian Plateau and the Lake Plateau) was influenced by regional tectonic uplift possibly due to uprising mantle plume(s) at $\sim 30 \mathrm{Ma}$. The later resulted in the formation of dynamic topography accompanying massive Ethiopian igneous intrusion followed by the onset of the East African-Red Sea rifting.

The findings of the current study support the development of the river and its drainage was controlled with the control of faults and folds as well as different inherited structures and basement fabrics along its path. The Nile Valley was incised along longitudinal fault-bounded grabens of NW to NNW orientation that was associated with the regional extension during the Oligocene Red Sea-Gulf of Suez rifting (Fig. 3.2 \& Fig. 3.4). The evolution of the drainage system in the Egyptian Nile was controlled by the formation of the Nile Valley and subsequent carving of the Eonile Canyon during the Messinian Salinity Crisis (Fig. 3.3). Before the onset of rifting and formation of the Nile grabens, the initial drainage systems of the river were possibly initiated with S-N and SSE-NNW flowing directions as the result of regional crustal uplifting that affected the entire Egyptian terrain, particularly the southern and northeastern domains.

\subsection{Possible St-(ages) of the Nile}

Several origins of the Nile have been addressed by controversial thoughts, and many authors have as well as suggested different st-(ages) for the initiation and development history of the river and its drainage systems. There are also two main ideas suggesting two older and younger ages for the evolution of the river in Africa and particularly in Egypt. It has been proposed that the Nile was probably evolved during the Oligocene or Late Eocene time (or even earlier, Late 
Cretaceous, e.g. Berry and Whiteman 1968; Youssef, 1968; Abdel-Rahman and El-Baz, 1979; Said, 1981; Youssef, 2003; Abdelkareem et al., 2012; Underwood et al., 2013; Abdelkareem and El-Baz, 2016), however other studies claimed a much younger age that the river might have been formed only in the Pliocene time 6-5 Ma (e.g. Heinzelin et al., 1964; Issawi and McCauley 1992; 1993; Issawi et al., 2008; Maxwell et al., 2010).

Other approaches were made by some authors (e.g. Abdelsalam, 2018) arguing that the two main drainage sources of the RN (the Central Lakes Plateau and the Northwestern Ethiopian highs) are shaped since $\sim 30 \mathrm{Ma}$, while the assembly of different drainage systems might have occurred only in the last 6 million years. Furthermore, the establishment of the present-day Nile's drainage system and the landscape of its basin might have been recent events, possibly occurred at $\sim 15$ ka ago. According to Faccenna et al. (2019), on the other hand, the Nile drainage has been stable for $\sim 30$ million years.

Among earliest studies on the possible st-(ages) of the RN, Berry and Whiteman (1968) considered that sections of the White Nile Valley in Sudan, and possibly Egypt, and their drainage systems were formed in the Late Cretaceous and Early Tertiary times, while the connection between them might have taken place in later times. They also suggested that the Blue Nile systems in Ethiopia must have had their origin in the Miocene and Pliocene times (for locations, see Fig. 3.1).

A growing body of literature have evolved proposing that the Nile Valley was possibly developed during the period between Late Eocene-Oligocene to Pliocene (Youssef, 1968; Abdel-Rahman and El-Baz, 1979; Said, 1981; Youssef, 2003; Abdelkareem et al., 2012; Underwood et al., 2013; Abdelkareem and El-Baz, 2016, among others); while during the Pliocene time, a long narrow extension of the Mediterranean sea entered into the formerlyformed graben of the Nile valley nearly to the extent of Aswan (Youssef, 1968; Said, 1993). In his studies on the geological evolution of the Nile, Said (1981) suggested that the river has been developed in successive periods between the Late Miocene and Pleistocene. He assigned different names for the River at each phase starting with the late Miocene "Eo-Nile", the Pliocene "Paleo-Nile", and finally three stages were developed during the Pleistocene time (Proto-Nile, Pre-Nile, and Neo-Nile). 
During all of these stages, the river had always a northward flow-direction (Fig. 3.1 \& Fig. 3.2). The latest Miocene "Eonile" flowed in a south-north direction and incised a deep canyon of $\sim 600 \mathrm{~m}$ depth in the north near Cairo, and $\sim 200 \mathrm{~m}$ close to Aswan in the south (Said, 1981). This study found that the depth of the Eonile Canyon in Beni Suef, near Cairo, reaches $\sim 1900 \mathrm{~m}$ (Fig. 3.1). The incision of the Eonile canyon was aided by headword extensive erosion of the northerly flowing drainage contemporaneously with the widely known "Messinian Crisis". The later event witnessed an extreme drop of the Mediterranean Sea-level at 6-5 Ma, which was followed by widespread evaporation and severe desiccation (Hsü et al., 1973, 1977; GarciaCastellanos et al., 2009).

It was also assumed by some authors that the Nile in its present-day shape is rather a very young river that was probably formed during the Pleistocene time (Heinzelin et al., 1964; Issawi and McCauley 1992; 1993; Issawi et al., 2008; Maxwell et al., 2010). In their work on the evolution of the Cenozoic river systems in Egypt, Issawi and McCauley (1993) proposed three major drainage systems that were formed since the late Eocene with different flowing directions, El-Gilf, Wadi Qena and Nile rivers, from older to younger, respectively. The oldest river, El-Gilf, was developed as a result of the regional northward retreat of the Tethyan Sea during the Late Eocene and sea-level fall in the Oligocene (Haq et al., 1987). The river drained the Red Sea highlands northwestward through the Western Desert of Egypt to the Tethys shoreline at the present-day location of Siwa Oasis. Following the Gilf system, tectonic activity in the north of the Red Sea area caused a southward tilting and runoff of the Wadi Qena. The present Nile began as the surviving parts of the Qena and Gilf systems, e.g. capturing the southward flow of Wadi Qena to become the first northward flow for the Nile.

Abdelsalam (2018) concluded that the Ancestral Nile dominated the drainage system of Egypt in the period immediately before $\sim 6 \mathrm{Ma}$, and was followed by the carving of the Eonile Canyon during the Messinian Salinity Crisis (see Fig. 3.3). The latter event can be considered as a sign for the development of the Egyptian Nile, which possibly connected to the rest of the Nile System only $\sim 2.5 \mathrm{Ma}$ ago and persisted to the present-day. 


\section{Chapter 4 Regional Tectonics and Continental Rifts}




\section{Introduction}

Large rivers differ in their form and function, and for many rivers the understanding of such differences is achieved through the history of continental plate movements and small-scale tectonics (Gupta et al., 2020). The sedimentary record is essentially identical all over southern and central Egypt along the Nile Valley (see Fig. 1.5 \& Fig. 1.6). Sporadic magmatic activity continued throughout the Paleozoic. From Cambrian to Early Carboniferous, the regional $\mathrm{N} 150^{\circ}$ fault trend dominated the paleogeography with its large-scale horst and graben-type structures (Klitzsch, 1990). Sedimentation for most of the Paleozoic was controlled by global eustatic sea-level changes with clastic sediments mainly derived from the Pan African highlands which were probably glaciated for at least part of the Early Paleozoic. The collision of Gondwana with the northern continents during the Late Carboniferous led to the reactivation of the E-W oriented faults in southern Egypt and northern Sudan, which controlled the sedimentation and facies distribution during the Permian-Early Jurassic time (Klitzsch, 1986). Differential vertical movements affected Nubia throughout the Mesozoic, and the drainage regime which had switched from northward to southward late in the Paleozoic reverted to northward once again in the middle of the Mesozoic Era, probably in the Middle Jurassic (Klitzsch, 1984).

However, a complex history of crustal extension occurred in northern, eastern and southern Egypt during the Mesozoic, Late Paleogene, and Neogene tectonics. The majority of the intracontinental rift structures that are proposed here along the Nile Valley belong to the tectonics and structural setting of southern and central Egypt as part of the structural domain that was, however, described by Said $(1962,1990 b)$ as a "stable shelf". The structures of the NW Late Paleogene-Early Neogene rift segments have probably controlled the development and geometry of the ancestral and present-day $\operatorname{river(s)}$ and their drainage systems in the southern and central tracts of the Nile Valley (Fig. 4.1). The tectonostratigraphic evolution and structural characteristics of northern Egypt, on the other hand, are comparatively different and thus this region was described as "unstable shelf" (Said, 1962), which has suffered successive and severe extensional and compressional phases particularly during the Mesozoic tectonics. 


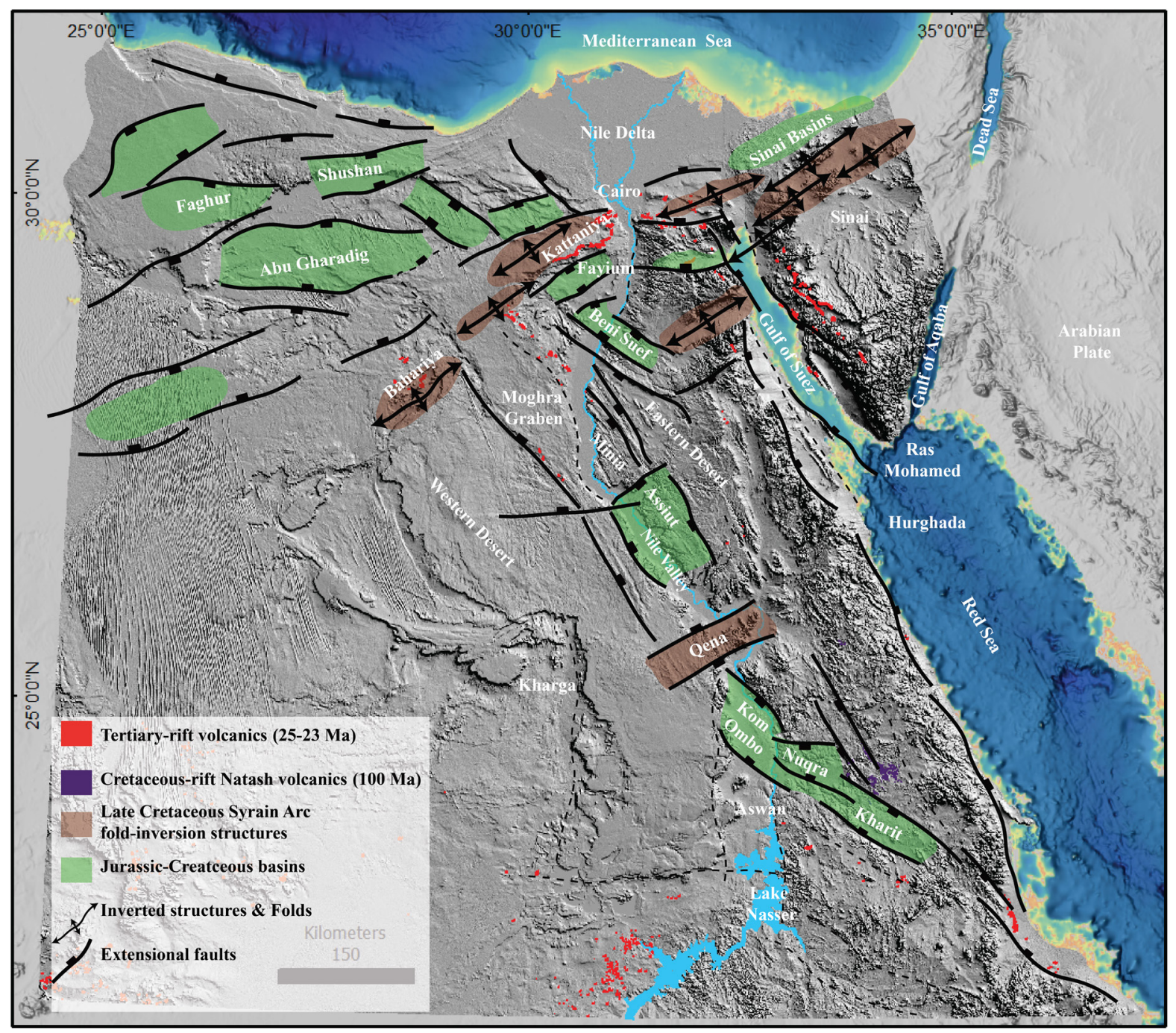

Fig. 4.1. The major Mesozoic and Cenozoic rift basins in Egypt. The map shows the distribution of the NW to NNW-oriented Early Cretaceous rift basins in southern and central Egypt along the course of the River Nile, and the Red Sea-Gulf of Suez rift system. It also indicates the distribution of the E-W to NE-oriented Jurassic-Cretaceous basins of northern Egypt, particularly the north Western Desert. The inverted basins and major uplifted fold-fault structural belts of the Late Cretaceous Syrian Arc tectonics are also highlighted. This in addition to the Late Oligocene proposed rift structures along the Nile. The locations of basins and inversion-fold structures are modified after Bosworth (2015). Notice the distribution of rift-related Cretaceous and Tertiary volcanics across the rift basins and shoulders, modified after Klitzsch et al. (1987).

The Mesozoic and Cenozoic regional tectonics in northern and eastern terrorises of Egypt are well documented and widely understood owing to the extensive petroleum exploration activities in the North-Western Desert and Gulf of Suez basin (Fig. 4.1 \& Fig. 4.2). This has provided geologists with abundant gravity, magnetic, borehole, and seismic datasets that have been used and published in several relevant studies and reports. Conversely, the tectonics and structural architecture of most of the central and southern basins are yet poorly understood with limited subsurface datasets. Major extensional/wrench faults and fold belts of E-W to ENE trends controlled the tectonic setting of the Jurassic-Cretaceous structures and basins in northern Egypt (Fig. 4.1). While, the development and geometry of the Cretaceous, Late 
Paleogene and Neogene rift basins in the southern and central tracts along the Nile Valley were controlled by NW- and NNW-striking major faults and Precambrian basement shear zones (Fig. 4.1, see also Fig. 2.11 \& Fig. 2.13).

\subsection{Northern Egypt Tectonics}

The structural deformation of the northern mobile unstable shelf was characterized by rapid basin subsidence and the development of a series of deep-seated faults (Youssef, 2003). Northern Egypt was influenced by extensive marine transgressions associated with the Mesozoic rifting phases that resulted in the formation of several E-W, ENE- and NE-oriented rift basins and sub-basins with thick accumulations of Jurassic and Cretaceous sedimentary sequences as well as widespread intrusions of alkaline magmatism in both the rift basins and shoulders (Dolson, 2020) (Fig. 4.1 \& Fig. 4.2). These tectonics with the same structural style and rift basins geometries did not spread onto the central and southern territories "unstable shelf' whereas rift basins with different trends were developed (Dolson et al. 2001, 2014).

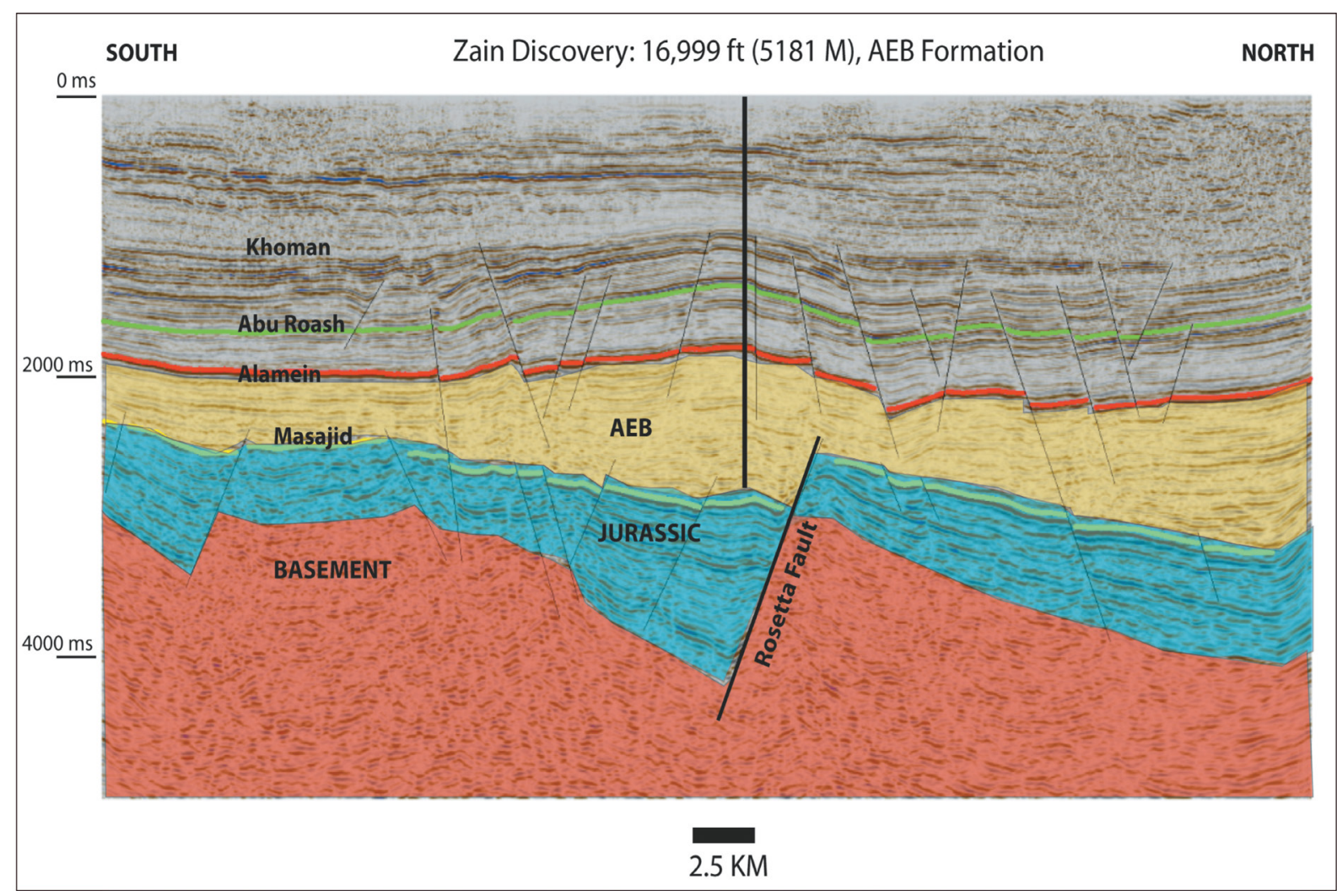

Fig. 4.2. Seismic section in the north Western Desert showing one of the major Jurassic half-graben rift basins that were inverted during the Late Cretaceous Syrian Arc tectonics, after Dolson et al. (2014). 
The earliest development of E-W to ENE-oriented half-grabens and asymmetric rift basins have probably occurred during the Late Triassic-Early Jurassic through N-S and NNW-SSE extensional rifting accompanied the breakup of Pangea that resulted in the opening of the protoMediterranean-Neotethys basin in northern Egypt (Keeley, 1994; Dolson et al., 2001; Guiraud et al., 2005; Aal and Lelek, 2013; Moustafa, 2020). The major marine transgression commenced on the stable shelf during the Late Cretaceous and by the end of the Eocene (Hantar, 1990; Said, 1990a; Keeley, 1994). While minor, local lithologic variations in the Upper Cretaceous-Lower Cenozoic stratigraphic succession have been documented.

The major faults that bound most of northern Egypt's deep rift basins have dominant ENE and NE trends in addition to cross elements of NW and NNW orientations with less frequencies (Guiraud et al., 2001; Moustafa, 2008; 2020) (Fig. 4.1, see also Fig. 2.11 \& Fig. 2.13). These deep rift basins and their bounding faults extend from the north Western Desert into the eastern offshore Mediterranean and northern Sinai (Fig. 4.2). Subsidiary faulting associated with transtensional evolution of the Jurassic-Early Cretaceous rift basins often strike $45^{\circ}-75^{\circ}$ from these regional fault trends, and controlled syn-rift structures and deposition on a sub-basin scale (Dolson et al., 2014) (Fig. 4.2). The ENE and NE thick rift basins, the concomitant transcontinental structures, and underlying basement tectonic fabrics prolong across the northern extents of the Eastern and Western Deserts and represent the northern termination of both NW-oriented rifts; the Gulf of Suez in the east and the central Nile Valley rift segments and sub-basins, which extend between southern Aswan, northern Beni Suef basins and Bahariya-Fayium depressions.

\subsection{Central and Southern Egypt Tectonics}

Toward the south onto the so-called "stable shelf", the relative tectonic stability created subtle morphotectonic features and slightly dipping outcrops overlying shallow basins and subdued topographic highs. This in addition to slower rates of tectonic subsidence and extension as well as deposition of widespread, relatively thinner, sequences of continental and shallow marine sedimentary units. However, NW-oriented deep Mesozoic rift basins and half-grabens were formed in southern Egypt and northern Sudan and accommodated considerable thicknesses of non-marine lacustrine and fluviatile sediments (Schull, 1988; Bosworth, 1992; Taha, 1992; 
Dolson et al., 2000) (Fig. 4.1, Fig. 4.3 \& Fig. 4.4). These basins were most likely not connected to the Tethyan open-marine rift systems in northern Egypt.

The Mesozoic to Paleogene sedimentary history in northern Egypt was similar to that in southern Egypt except for additional tectonic control at depocenters and near positive structures (Sestini, 1984). These tectonic elements include Late Paleozoic features that remained active, new Mesozoic features, and features that became inverted during the Late Mesozoic or Early Cenozoic. Most of these features trend roughly E-W or ENE and the fault systems show a trend similar to the one that affected southern Egypt during the Cretaceous and possibly later (Klitzsch, 1984). Many of the tectonic movements appear to have been roughly coincident with the initiation of Atlantic rifting, particularly rifting of the South Atlantic, but details of the regional Mesozoic tectonics in northeast Africa are not yet fully understood.

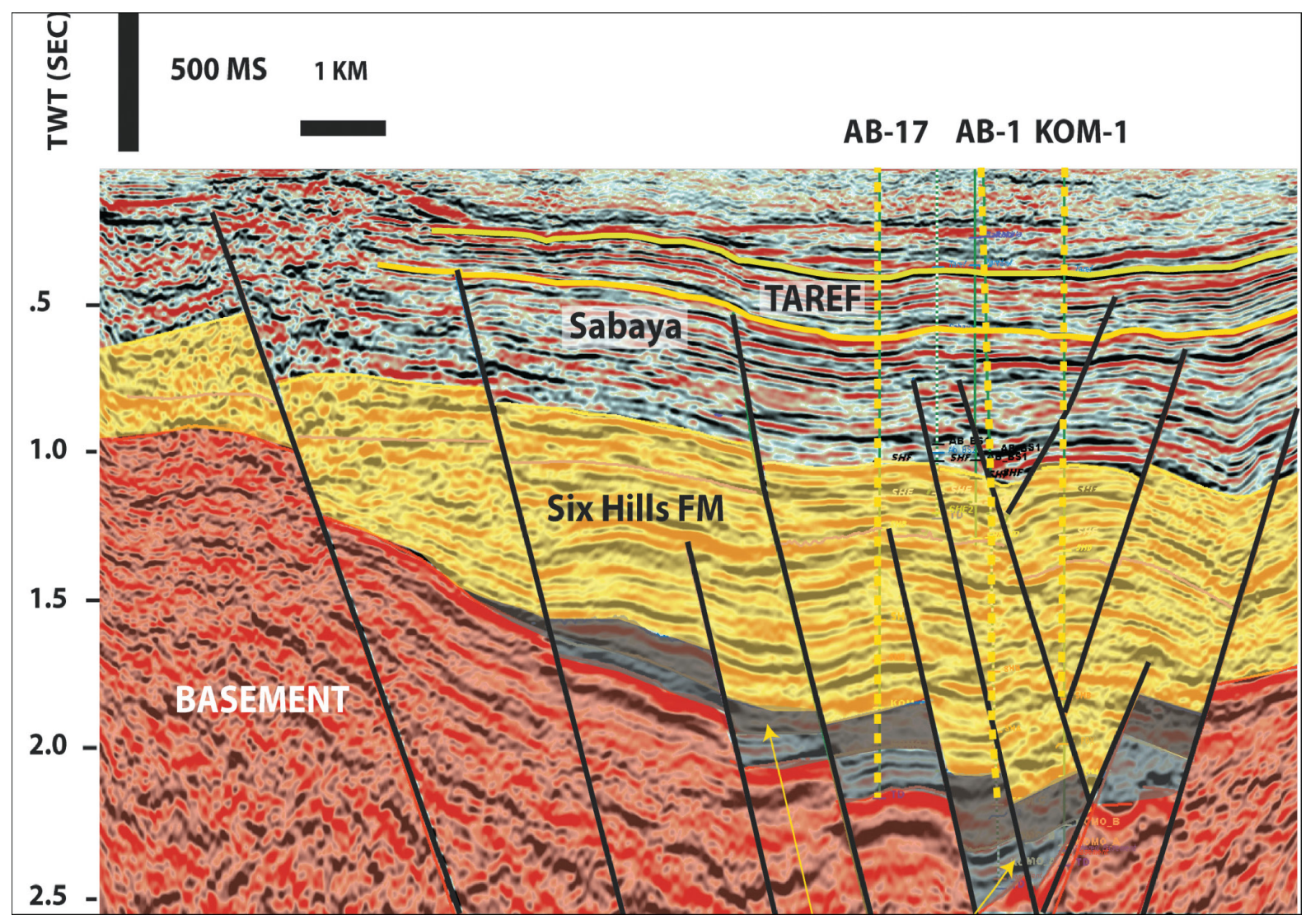

Fig. 4.3. Interpreted (SW-NE) seismic section in the Early Cretaceous KomOmbo rift basin in southern Egypt. After Dolson et al. (2014), data courtesy of Dana Gas Egypt. For the stratigraphic units, please see Fig. 1.6. 
The NW-SE orientation of these rift basins, their boundary faults and the overlying grabens and structures suggest intracontinental rifting that accompanied successive regional extensional tectonism of NE-SW orientation. The horizontal stresses reactivated the inherited Pan African shear zones of the underlying Proterozoic basement complexes (see Fig. 2.11). The earliest phase of the extension was probably associated with an abandoned breakup of the Afro-Arabian plate during the Cretaceous rifting contemporaneously with the opening of the Atlantic. These extensional phases were intermittently reactivated during later times particularly the Late Paleogene NE-SW extension that formed the Red Sea-Gulf of Suez rift systems and resulted in the separation of the Arabian microplate. The spatial extents of the Cretaceous basins and their overlying shallow rift segments in southern and central Egypt along the Nile Valley are comparable to that of the Red Sea-Gulf of Suez rift system in the east (Fig. 4.5).

\subsection{Syrian Arc Tectonics}

Several of the Jurassic-Early Cretaceous rift-bounding faults were inverted during the Late Cretaceous-Early Eocene time as the result of the convergence between Africa and Eurasia and closure of the Neotethys (Moustafa et al., 1998; Bosworth et al., 1999; Dolson et al., 2000; Guiraud et al., 2005; Bosworth et al., 2008; Bevan and Moustafa, 2012) (Fig. 4.1 \& Fig. 4.3). This led to regional N-S and NNW-trending compression and transpression, dextral strike-slip movements along ENE- to E-W striking faults, the formation of many ENE to NE-trending fold-thrust-fault belts and development of positive features and elongated ridges across northern Egypt. These belts extend from Syria to the Atlantic Ocean via northern Africa and ere commonly known as "Syrian Arc" folds (Krenkel, 1925). ENE to NE-trending folds are well exposed in northern Sinai and along the northern GOS rift shoulders and in the subsurface underlying the syn-rift sediments (Moustafa and Khalil, 1990; 1995), and were also reported in the subsurface of the northern Western Desert and Cairo-Suez district (Moustafa and El Shaarawy, 1987; Bosworth et al., 1999) (Fig. 4.1 \& Fig. 4.3). The transpression tectonic regime was climaxed during the Early Senonian time and resulted in the emergence of most parts of the northern GOS above the late Senonian sea level (Guiraud et al., 2005). Most of the Syrian Arc structures in northern Egypt's basins terminated during the Late Senonian. 
However, the Syrian Arc folding and regional uplifting phase might have extended in some parts in southern Egypt to the Late Eocene and Early Oligocene time. The Syrian-Arc structures in the southern basins are restricted, especially in Nuqra and Kharit, and basins received the younger sediments (Mostafa et al., 2016). The eastern basins were uplifted in later times possibly in association with basement uplifting during the Red Sea rifting

\subsection{Precambrian Basement Structures}

Large-scale Basement faults and shears regionally affect the drainage systems and tributary networks in most of the river basins. The crystalline basement of Egypt is primarily of Precambrian age (El-Bialy, 2020). It is exposed extensively in the mountains of the Eastern Desert and the southern parts of the Sinai, and forms isolated exposures in the southern Western Desert (see Fig. 1.5). Youssef (2003) interpreted four main fault trends $\left(055^{\circ}, 070^{\circ}, 080^{\circ}\right.$, and $150^{\circ}$ ) represent major transcontinental and regional fracture zones in Egypt that were originated during different phases of crustal deformation in the Proterozoic. These fault systems were developed at the end of the Pan-African orogenic phases and amalgamation of the Proterozoic craton.

The subsequent intracontinental tectonic events and accompanying processes of uplift, deformation, erosion and sedimentation were generally controlled by fault/fold trends which were commonly reactivated along inherited tectonic fabrics. The initiation of the Nile Valley rift has been controlled by the preexisting Pan-African weakness zones (Abd-Allah, 2008). The subsurface images (SEEBASE maps) of the base of the Paleozoic and Cretaceous stratigraphic sequences show that the distribution and size of the basins of Egypt are controlled by the structural characteristics of the underlying basement terranes (Steffan et al., 2000) (Fig. 4.4).

The map shows significant Precambrian basement and Cretaceous faults and shear zones that controlled the distribution, structural architecture, and tectonic evolution of the NW and NNWtrending Cretaceous rifts as well as the succeeding reactivation and development of the Oligocene rifting along the longitudes of the Nile Valley (Fig. 4.4, see also Fig. 2.11 \& Fig. 2.13). Oceanic and transitional crust limits are located west of the Nile Delta and north of the Western Desert -basins (Dolson et al., 2014) . Deep-seated basement shears appear to have 
disturbed the overlying sedimentary rocks that affect the architecture and orientations of the drainage system of the ancestral Nile basin, particularly in NW and NNW directions.
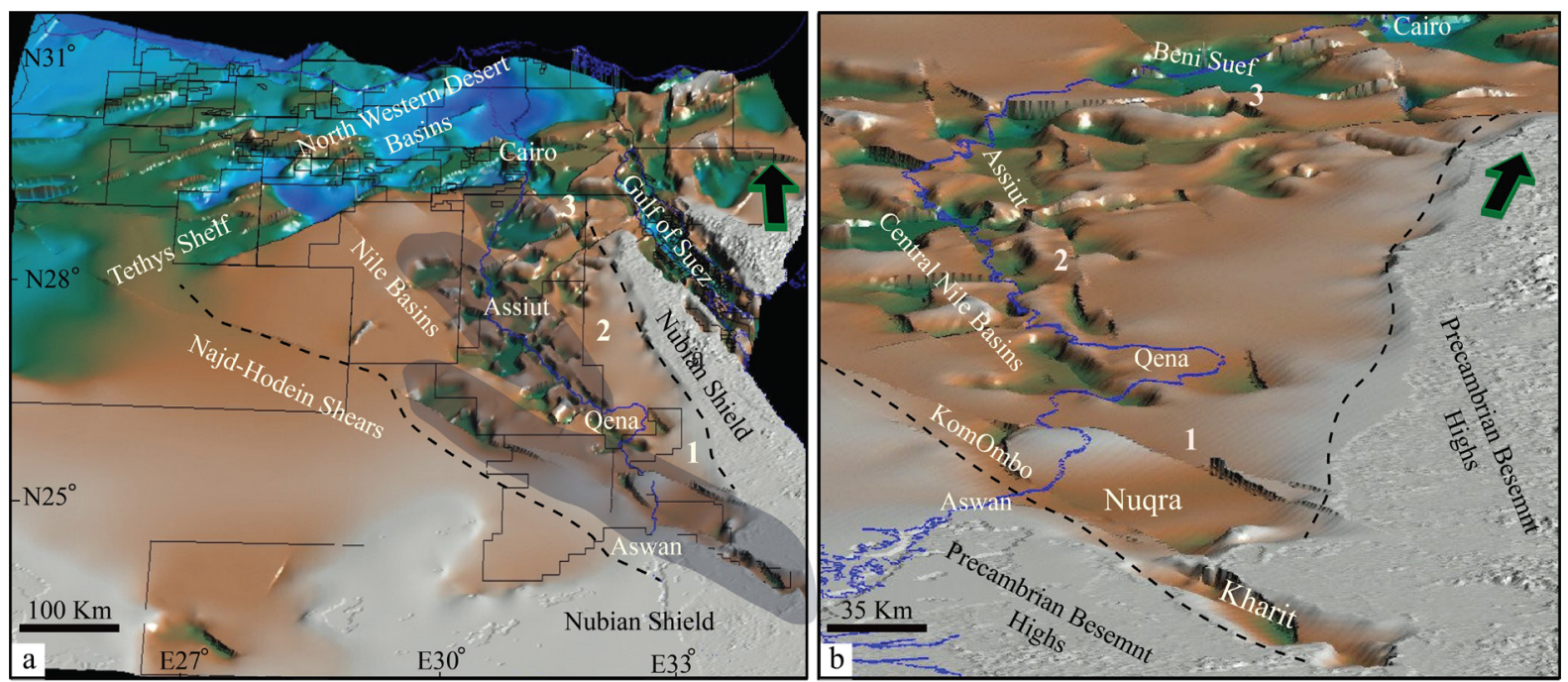

Fig. 4.4. SEEBASE map showing the Cretaceous rift basins of the North Western Desert and Nile Valley. It displays the major influence of the mega-shear zones and tectonic fabrics of the Precambrian Basement on the evolution and geometry of the $N E$-, NW- and NNW-oriented rift basins along the Nile. The numbers 1, 2 and 3 indicate the three main Nile rift segments that are considered in this study as southern, central and northern, respectively. Data from Steffan et al. (2000).

The alignment of the Nile rift segments and the subsequent drainage basins was also controlled by basement lineaments and pervasive rift-parallel and rift-orthogonal/oblique faults and shear zones along the river course (see Fig. 1.4 \& Fig. 1.5). The tectonic evolution and geometry of both Cretaceous and Late Oligocene Nile rift systems were strongly influenced by pre-existing basement structures (see Fig. 2.11 \& Fig. 2.13). The Cretaceous Syrian-Arc structures show a significant effect on the orientation, segmentation and termination of the Late Oligocene phase of the Gulf of Suez and Nile rift segments and structures (Fig. 4.1 \& Fig. 4.4). The exposed Precambrian basement rocks along the southern and central Gulf of Suez margins are composed mainly of gneisses and granites with extensive NNW-NW-trending foliations and shear zones (Najd trend), N-S fractures and faults, NNE-NE-trending dikes, and NE \&NW Joint sets (Fig. 4.5). The characteristic zigzag patterns of the rift-bounding, rift-coastal, and intra-basin faults were formed through rejuvenation and linkage of these Precambrian-Early Paleozoic inherited structures and fabrics during the Late Oligocene GOS rifting (Garfunkel and Bartov, 1977; Patton et al., 1994; Younes et al., 1998) (Fig. 4.5).

Many of the Nile Valley NW to NNW-trending extensional faults and their linking cross-faults might have reactivated and precisely followed Precambrian basement joints and Early 
Cretaceous faults. Reactivation of the Late Cretaceous E-W, ENE- and NNW-striking faults effectively controlled the development and location of the accommodation zones, and the riftoblique and rift orthogonal-faults which acted as hard-linkage transfer segments for the riftparallel faults in both the Nile Valley and Gulf of Suez (Fig. 4.5; see Fig. 1.5). Eocene E-W fold-fault belts extending along the Bahariya-Fayium district were possibly reactivated along inherited structures of the Jurassic-Cretaceous rift faults and the Late Cretaceous Syrian Arc system. This area hosts the majority of the Oligo-Miocene syn-rift sediments and rift-related basalt intrusions and flows in the northern Nile Valley area (see Fig. 2.11 \& Fig. 2.13).

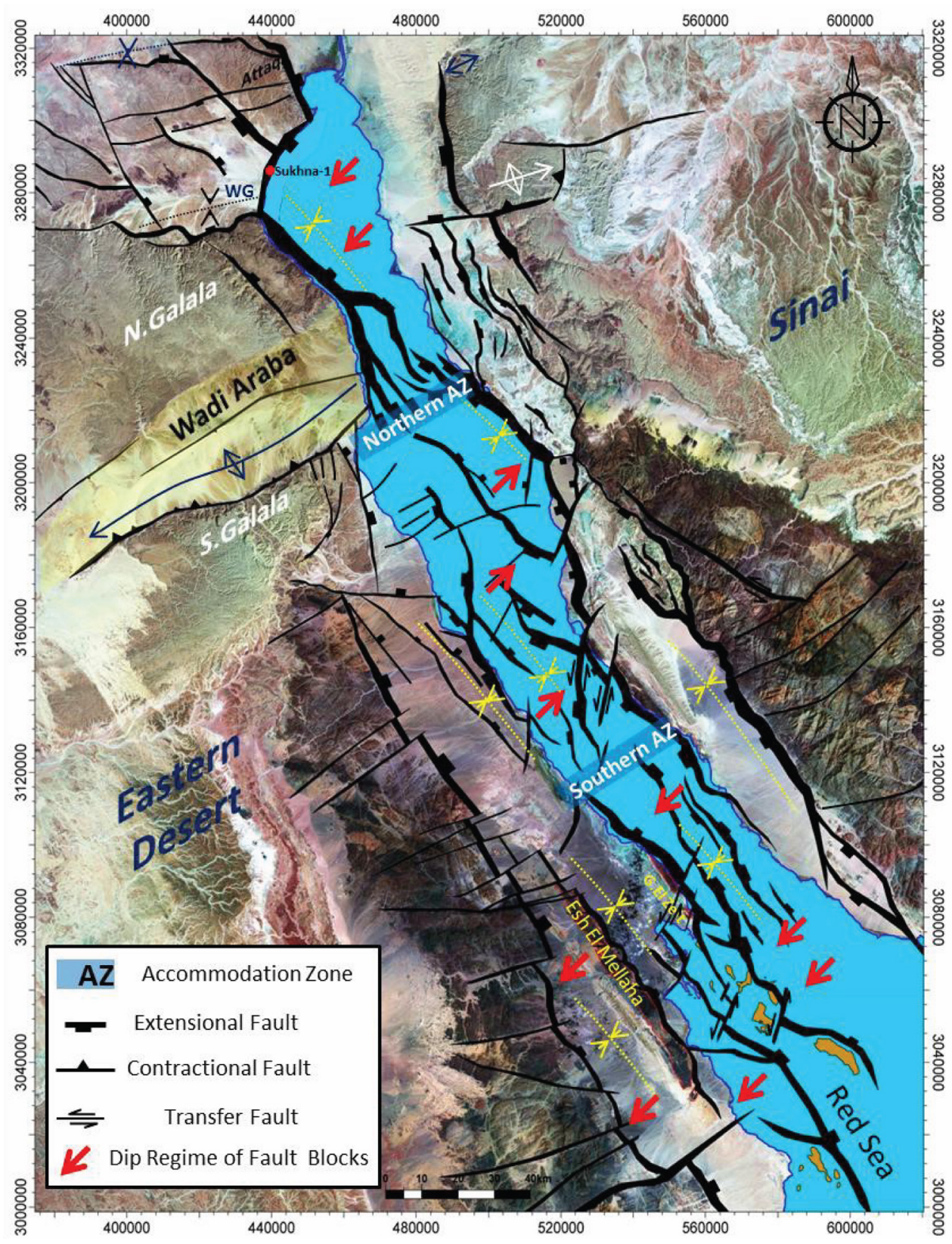

Fig. 4.5. The structural architecture and segmentation of the Late Oligocene Gulf of Suez rift basin. Compiled from McClay et al. (1998), Bosworth and McClay (2001), Abdelkhalek (2014). 


\subsection{Continental Rifts in Egypt}

The earliest syn-rift sedimentary sequences in most of the continental rifts start with the deposition of fluvial and alluvial sandstones, conglomerates and red beds usually of a limited thickness (Baldridge et al., 1995; Lambiase and Bosworth, 1995; Roberts and Bally, 2012) (Fig. 4.6). During the initiation of intracontinental rifts, the sediments accumulate in limited, shallow and narrow basins that developed in broad areas dissected by numerous early-rift faults of minor displacements associate with alkaline volcanic intrusions (e.g. West of the Gulf of Suez rift, see Fig. 4.9; West of the Nile rift, see Fig. 4.10 \& Fig. 4.11). Rifts that form near sea level and are connected to the world ocean develop marginal marine/shallow marine sedimentary facies but otherwise are similar to intracontinental rifts, however for land-locked basins the lakes, if present, are generally small, shallow and isolated (Bosworth et al., 2015a).

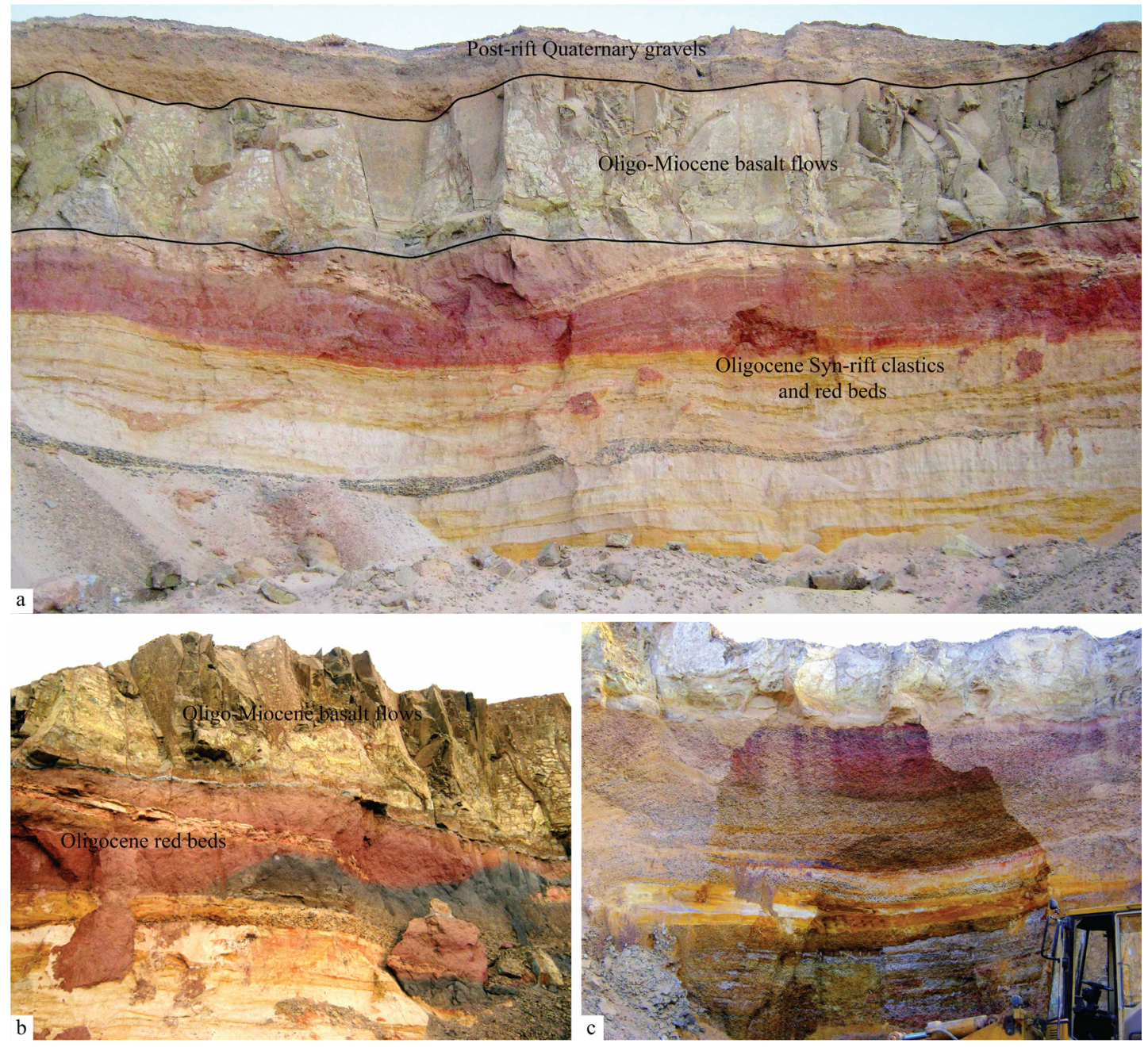

Fig. 4.6. The Late Oligocene rift-related red beds and basalt flows, western onshore of the Gulf of Suez. a) Thick basalt flows overlaying the early-syn rift Oligocene red beds and clastics. b) The effect of the basalt flows on the Oligocene red beds and clastics. c) Thick succession of Oligocene (syn-rift) fluviatile coarse clastics, conglomerates and cross-bedded red sandstones. 
The rates of tectonic subsidence and fault-throws increase with progressive extension and vertical growth of rift-bounding faults, which results in the development of grabens and halfgraben fault blocks in deeper basins across the area of extension with a relatively rapid accumulation of shallow marine sediments (Fig. 4.7 \& Fig. 4.8, see also Fig. 4.2 \& Fig. 4.3). Early phases of extension at low strains produced alternating half-graben/accommodation zone geometries similar to those observed in most young and active continental rifts, while at higher strains, some border faults were abandoned so that through-going, simpler active fault systems could evolve (Bosworth, 1992). This is interpreted as representing a switch from complex, oppositely dipping detachment structures, to regional detachment structures that continue for hundreds of kilometers parallel to the rift.

\subsection{Early Cretaceous Rifts}

Multiple successive periods of extension, magmatism, rifting and tectonic subsidence dominated in northern, central, eastern and southern Egypt during the Jurassic, Cretaceous and Late-Paleogene-Early Neogene times. These tectonic phases have resulted in the development of several rift basins of different orientations and distinctive tectonostratigraphic sequences (Fig. 4.1). The phases of the extension were interrupted on some occasions by periods of thermal sagging and formation of passive margins, while in other cases by compression, basin inversion and regional uplift and erosion. The multiple periods of extension in southern and central Egypt resulted in the reactivation of the rift basins and their bounding faults. The trends of these basins and faults during their both initiation and reactivation were controlled by the orientation of the pre-existing structures (Fig. 4.4, Fig. 4.7\& Fig. 4.8).

The Early Cretaceous marked a period of rejuvenated rifting in northern Egypt with a clockwise rotation of the Late Jurassic extensional tectonic regime, and was followed by a post-rift thermal sag associated with the development of a passive-margin and widespread sea transgression along the northern stretches of Northeast Africa. NNW (Late Jurassic) to N-S (Early Cretaceous) extensional tectonic regime dominated in northern Egypt and created E-W to ENE-oriented Mesozoic rift basins with southward thinning and marine-to-continental facies change of the syn- and post-rift sediments (Morgan, 1990; Guiraud et al., 2005; Wescott et al., 2011; Dolson et al., 2014). These rifting phases were associated with alkaline magmatic events 
at $\sim 140-150 \mathrm{Ma}$ and $\sim 105-115 \mathrm{Ma}$ (Meneisy, 1990), which was coincident with initial rifting in the Atlantic. The Central and East African territories, on the other hand, witnessed a regional E-W extension during the Late Jurassic time that resulted in the development of a large system of interior rift basins extending from southern Kenya to northern Sudan and southern Egypt with basinal axes and rift border faults of a dominate NW orientation (Schull, 1988; Bosworth, 1992). The formerly developed Jurassic basins were rejuvenated in the Early Cretaceous rifting and extended further south and north, while by the Late Cretaceous the extension direction shifted to the NE-SW, and the widely observed NW-SE rift geometry was developed. In the early Tertiary, some Mesozoic rift basins were again reactivated, while other regions experienced wrench faulting and basin inversion (Bosworth, 1992). During these rifting phases, the interior rift basins in Sudan revived thick non-marine sedimentary sequences including lacustrine shales, claystone and sandstones, floodplain claystone, and fluvial-alluvial sandstones and conglomerates (Schull, 1988).

The southern and central parts of the Eastern Desert in Egypt were influenced by a regional NE-SW extension dominated during the Early Cretaceous time and resulted in intracontinental rifting associated with the formation of interior rift basins with prevailing NW to NNW orientation (Fig. 4.7 \& Fig. 4.8). The eastern shoulders of the southern basins were erupted by alkaline magmatic intrusions of continental affinities including ring complexes and trachyte plugs in addition to olivine basalts (Wadi Natash $~ 104$ Ma; Meneisy, 1990). These basins were tested during the last twenty years of petroleum exploration and were proven to extend deeply along the Nile Valley in the southeastern stretches of the Eastern Desert, which were previously considered as part of the area that is widely described as "Stable Shelf" structural domain.

A salient difference in the geometry and orientation of the E-W and ENE-trending Cretaceous rift basins in the north and their equivalent segments in the central and southern territories along the Nile Valley that are characterized by a major NW-trend (Fig. 4.1 \& Fig. 4.4; see also Fig. 2.11 \& Fig. 2.13 ). This can be attributed to the different geodynamic evolution associated with changes in both the regional extension direction and the main trends of the controlling Precambrian basement shear zones as well as the inherited pervasive tectonic fabrics in each of these structural domains. 
The northern E-W and ENE rift basins were developed as the consequence of N-S and NNWSSE extension that dominated in North Africa during the Jurassic and Cretaceous accompanying the opening of the Neotethys Ocean. While, the NW- and NNW-oriented southern and central Nile basins were formed by NE-SW regional extension associated with the opening of the Atlantic Ocean, which prevailed through Central Africa and created many rift basins of the same orientation in Sudan and Kenya. Another possible reason is the Cretaceous reactivation of the major NW-striking Pan African shear zones in southern Egypt (Najd-Hodein shear fault system) (Fig. 4.4). The latter trend is $\sim 10^{\circ}-15^{\circ}$ oblique relative to the main NNW trend of the Red Sea-Gulf of Suez rift system (Fig. 4.5). This can also explain the relative difference between the orientations of the Late Paleogene-Early Neogene NW Nile rift segments and the NNW segments of the Red Sea and Gulf of Suez basins.

The reactivation of the Najd shear zones along the southern Nile controlled the NW orientation of the rift basins during the Early Cretaceous and successive rifting phase, particularly in southeastern Egypt (Fig. 4.4). The NW orientation of the faults can be attributed mainly to the Cretaceous rifting phases, while the NNW trends are related to the Late Paleogene and Neogene extension (Fig. 4.7, Fig. 4.8 \& Fig. 4.9). Both trends, however, were active during the latter rifting phases as well as the cross elements that acted as transfer and linkage segments for the main fault trends (Fig. 4.5 \& Fig. 4.10 \& Fig. 4.11).

The Early Cretaceous rift basins in southern and central Egypt were aborted at a relatively mature stage with a mild inversion in later times of compression and wrench tectonism, while the overlying Neogene rifting phase was abandoned at a very early "embryonic" stage (Fig. 4.8). The "aborted" Cretaceous rift basins, their bounding faults, and transfer zones in southeastern Egypt are probably similar in their size, architecture, and geometry to those of the Oligo-Miocene Gulf of Suez rift system. Nagati (1986) and Taha (1992) were perhaps among the earliest studies that documented the presence of Mesozoic rift basins in southern Egypt such as E1 Nuqra, South of Qena basins and E1 Misaha basin to the west of Aswan. 
Three rift basins of a dominant NW orientation are located along the boundary of the Nile's drainage system in southern Egypt; from south to north are Kharit and Nuqra basins to the west of the present-day river valley, and KomOmbo basin to the east (Fig. 4.1 \& Fig. 4.4). These rift basins were influenced by the Late Cretaceous compression and inversion, where the inverted structures on the Cretaceous reflectors as well as the effect of the Syrian-arc tectonics can be traced on the Lower Eocene levels (Mostafa et al., 2016). The seismic and drilling results show Early Cretaceous maximum subsidence in the southeastern Nile basins of Nuqra and Kharit.

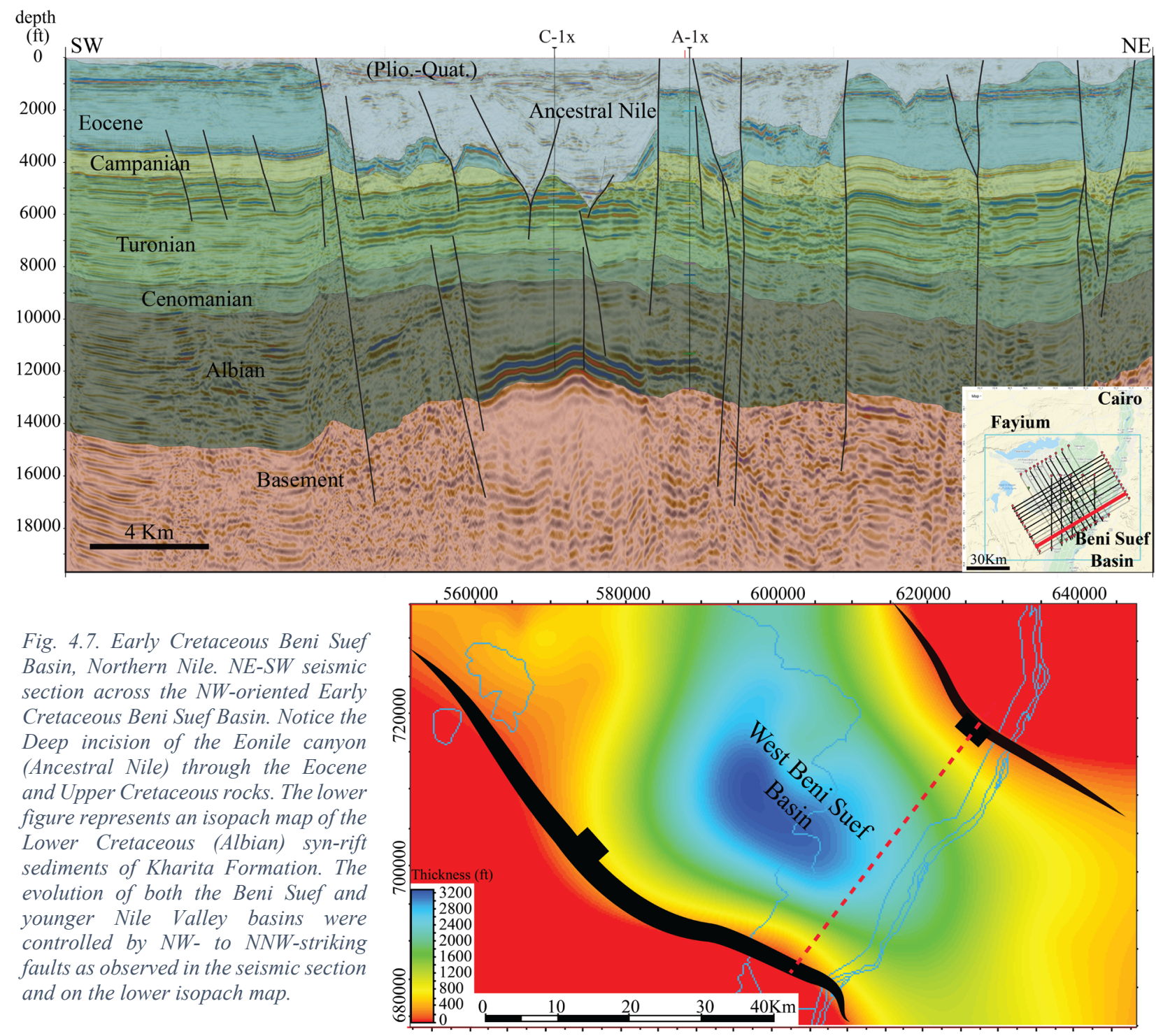


The Early Cretaceous section in southern Egypt's rift basins is represented by a restricted terrestrial environment, while the overlying stratigraphic sequences host a mixture of tidallyinfluenced reservoir units interbedded with palaeosols indicating an extensive Cenomanian transgression southward up the proto-Nile valley (Wood et al., 2012; Dolson et al., 2014). Mostafa et al. (2016) suggested that the up-dip extents of Nuqra basin are represented by shallow marine sediments as a good indication of basinal facies. Though the exploration activities in these basins have intensely increased during the past twenty years, most of them remain undrilled yet.

In addition, a vast amount of geophysical data have been acquired including aeromagnetic and gravity anomaly models, 2D and 3D seismic and borehole datasets, however, the detailed geometry, structural setting and tectonic evolution of these basins are still poorly understood. Further north, Assiut and Beni Suef basins are located in the west of the central and northern Nile Valley with a dominate NW to NNW orientation (Fig. 4.7 \& Fig. 4.8). The gravity and magnetic models as well as surface structures suggest the existence of a rift segment to the east of the central Nile, but the structural setting and geometry are not well documented due to the lack of seismic and borehole data. These basins were also formed during the Cretaceous rifting phases along the central and northern latitudes of the Nile Valley. 
Fig. 4.8. Early Cretaceous Assiut Basin, Central Nile. a) The map represents the measurement of the overall card surveillance gravity field. It shows the geometry and distribution of the NW-oriented basins along the central Nile Valley, the Early Cretaceous Assiut Basin, in addition to the EW and ENE-trending cross elements. b) depth-to-basement map based on gravity interpretation showing the structural architecture of Assiut basin and the geometry of the rift-bounding faults. c) Seismic section across Assiut basin showing the prominent thickening of the early synrift sediments of the Lower Cretaceous (Albian) Kharita Formation. The faults were reactivated during the latter phase of extension accompanied the Late Paleogene-Early Neogene rifting along the River Nile System.
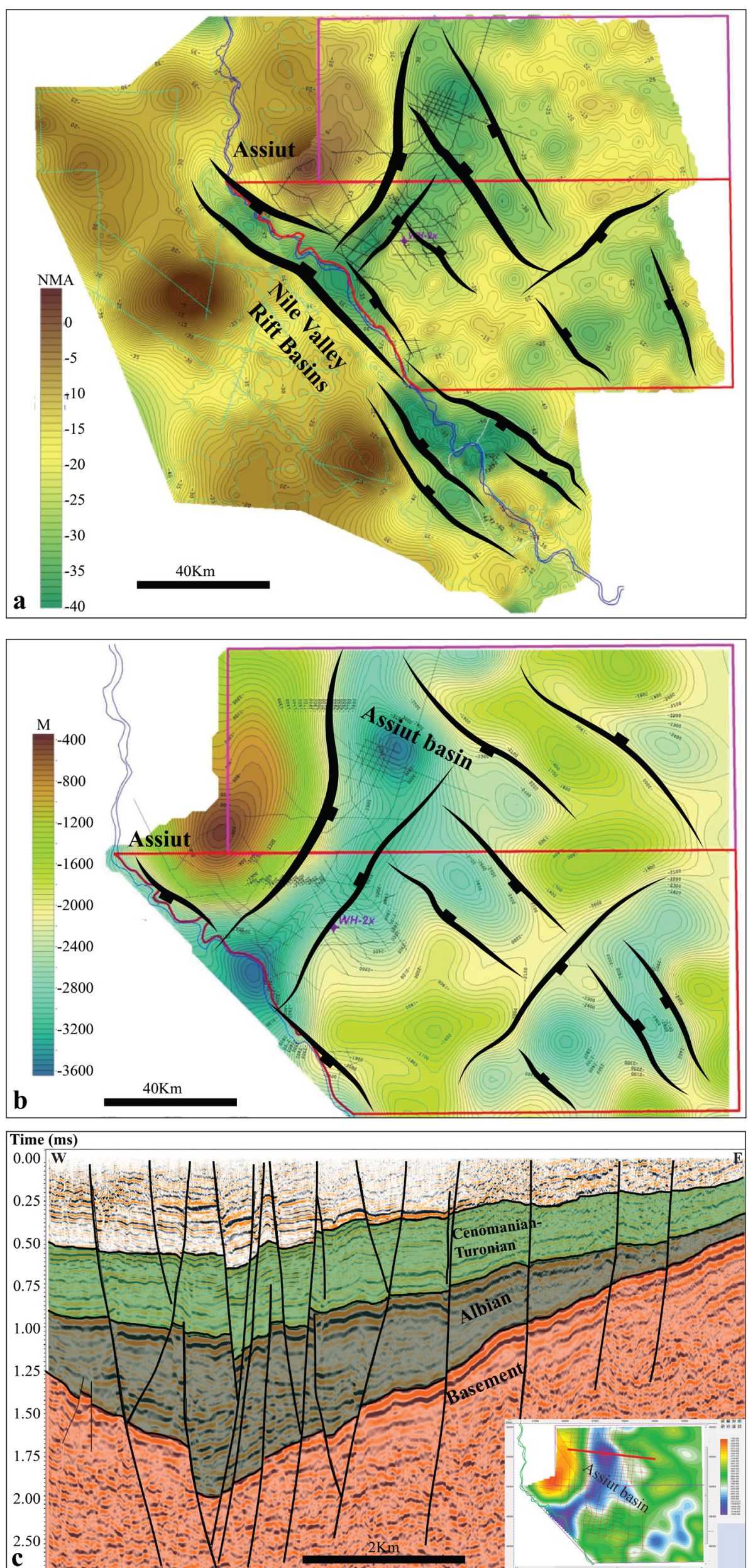


\subsection{Red Sea-Gulf of Suez Rifts}

The Red Sea is one of the youngest oceanic zones on earth that was formed by continental rifting of the Precambrian Arabian-Nubian shield, and along its length, it has been undergoing a transition from a continental rift to oceanic seafloor spreading (Rasul and Stewart, 2015). In connection with the Gulf of Aqaba-Dead Sea transform plate boundary, it represents the western borders of the Arabian plate and constitutes parts of the Afro-Arabian rift system (Fig. 4.1). It meets in a triple junction with the Gulf of Suez and Gulf of Aqaba at the southernmost tip of Sinai Peninsula.

The Red Sea rift system propagates to the north to form the abandoned-but-tectonically mature Gulf of Suez, the much smaller aborted rifts along the Bitter Lakes, and Manzala segment that is currently buried beneath the Nile Delta in addition to the very early abandoned embryonic rift along the present $\mathrm{RN}$ that this study suggests. The Oligocene grabens and rift basins of the Red Sea, the Gulfs of Suez and Aqaba and the Nile Valley were superimposed on parallel, oblique and orthogonal structures of the Cretaceous deformational phases. The Red Sea-Gulf of Suez hills form the shoulders of the rift system itself and the main western borders of the RN abandoned rift. Stratigraphic, radiometric and structural data indicate that extension and rifting initiated in the southern Red Sea during the late Oligocene ( 28-25 Ma), the start of rifting in the northern Red Sea is more difficult to constrain due to paucity of rift-related volcanism and reliable biostratigraphy of the oldest syn-kinematic sedimentary strata (Bosworth et al., 2020). The Red Sea started with rift-normal extension, and switched to oblique-rifting much later. Its oceanic rift was developed completely within continental lithosphere, without any connection to the world mid-ocean ridge system, where it is often suggested that the Ethiopian "Afar" plume triggered the onset of the Gulf of Aden-Red Sea rifting, or in some models, it was the main driving force (Bosworth, 2015).

The Red Sea rift was probably already a zone of structural weakness in the late Precambrian, with the breakup and rifting controlled by pre-existing fault systems (Ehrhardt and Hübscher, 2015; Bosworth et al., 2012, 2020). The northern part of the Red Sea has a highly attenuated continental crust as far south as the Zabargad Fracture Zone whereas seafloor spreading took place in the central and southern parts of the Red Sea. The $300 \mathrm{~km}$-long Gulf of Suez has been 
broadly considered as the failed arm of continental rifting that was initiated during the late Oligocene-early Miocene $23 \mathrm{Ma}$, and represents the northward propagation of the Red Sea rift (Garfunkel and Bartov, 1977; Chénet and Letouzey, 1983; Colletta et al., 1988; Richardson and Arthur, 1988; Patton et al., 1994; Robertson et al., 1996; Bosworth et al., 2015b) (Fig. 4.5)

Regional NW-SE-trending dike swarms of alkali basalt associated with extensive basalt flows in the Gulf of Suez, Northeastern Desert and around the Nile Valley would refer to the onset of crustal-scale extension and continental rifting in the Gulf of Suez and central Egypt (Fig. 2.9). The basalt dikes and flows have erupted at the Oligocene-Miocene boundary ( $23 \mathrm{Ma})$ and interbedded with the oldest part of the paleontologically dated siliciclastic early syn-rift Oligo-Miocene clastics, and are associated with the oldest recognized extensional faulting in the Red Sea (Bosworth et al., 2020) (see Fig. 4.10 \& Fig. 4.11). The Gulf of Aqaba-Levant transform boundary was initiated mid-way through the Red Sea's evolution ( $\sim 14 \mathrm{Ma})$.

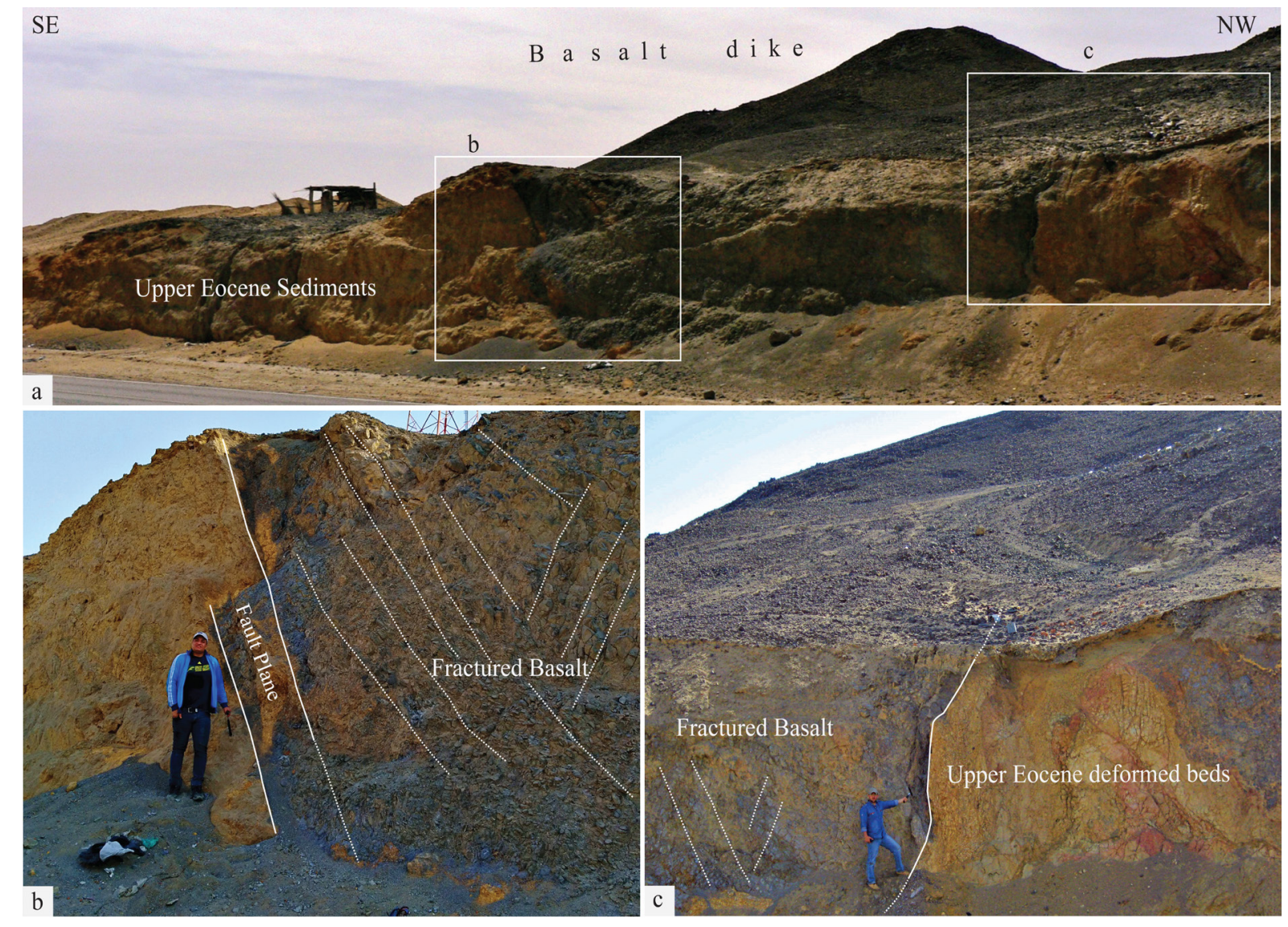

Fig. 4.9. River Nile-Gulf of Suez rift-related volcanism, the Qattamiya Mountain, Eastern Nile, western Gulf of Suez. a) Basalt fissure eruptions and flows along NW-oriented faults cutting through upper Eocene and Oligocene sediments. b) Highly fractured Basalt along NW-striking fault zone. c) Strongly deformed upper Eocene sediments as a result of the riftrelated extension and basalt intrusion. The age of Basalt in this locality is $\sim 21.5 \mathrm{Ma}$, according to ${ }^{40} \mathrm{Ar}{ }^{\beta 9} \mathrm{Ar}$ rage-dating of Bosworth et al. (2015b). 

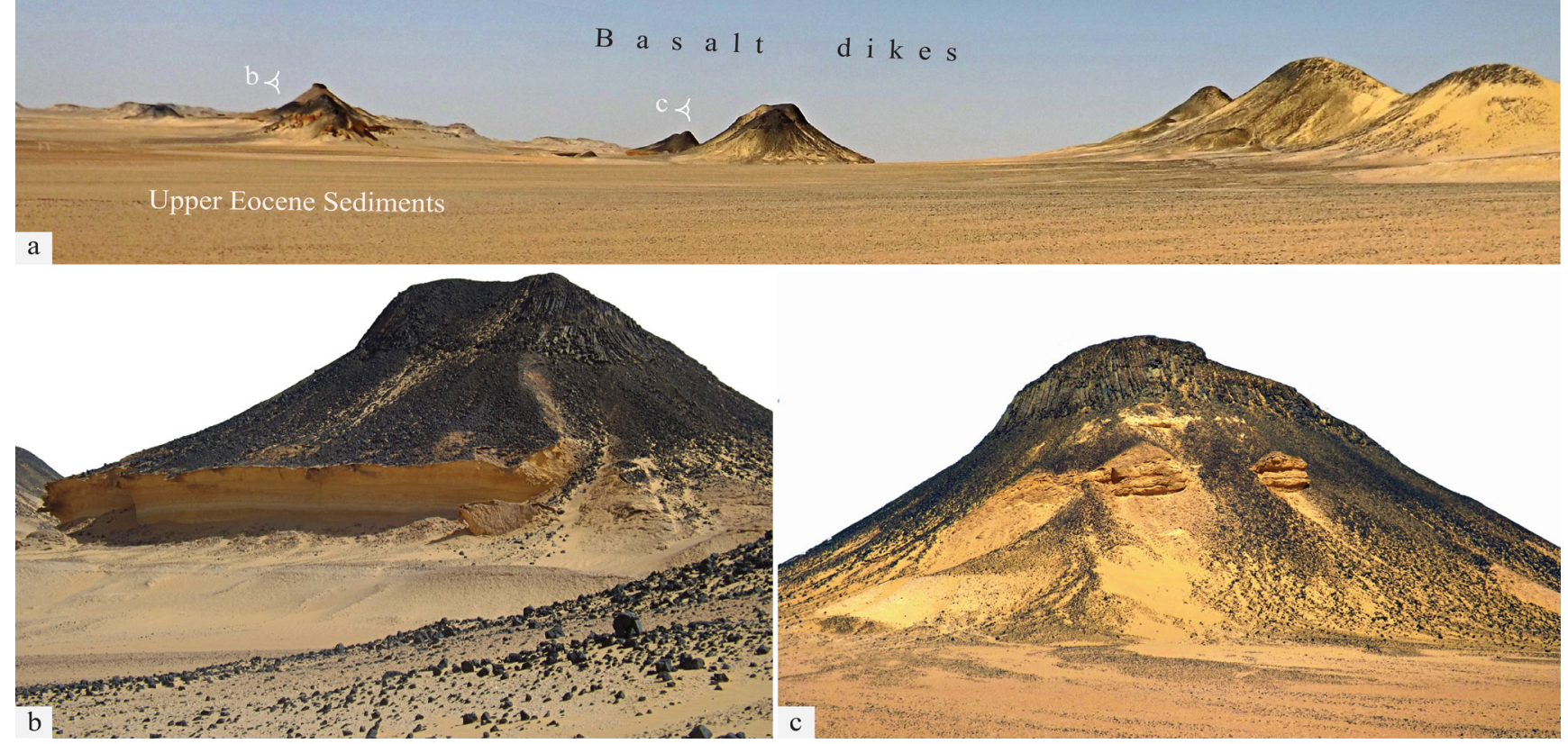

Fig. 4.10. The River Nile rift-related Volcanism, Western Nile, SW Fayium-Beni Suef. NW-oriented basalt dikes along faults of en-échelon pattern arrangement. b) Basalt rocks overlying the upper Eocene sediments of Qasr El-Sagha Formation. c) Columnar jointing of basaltic cinder cone. The age of basalt in this locality according to K/Ar age-dating of the present work is 21 Ma, see Table 1; Sample (QZ-1).

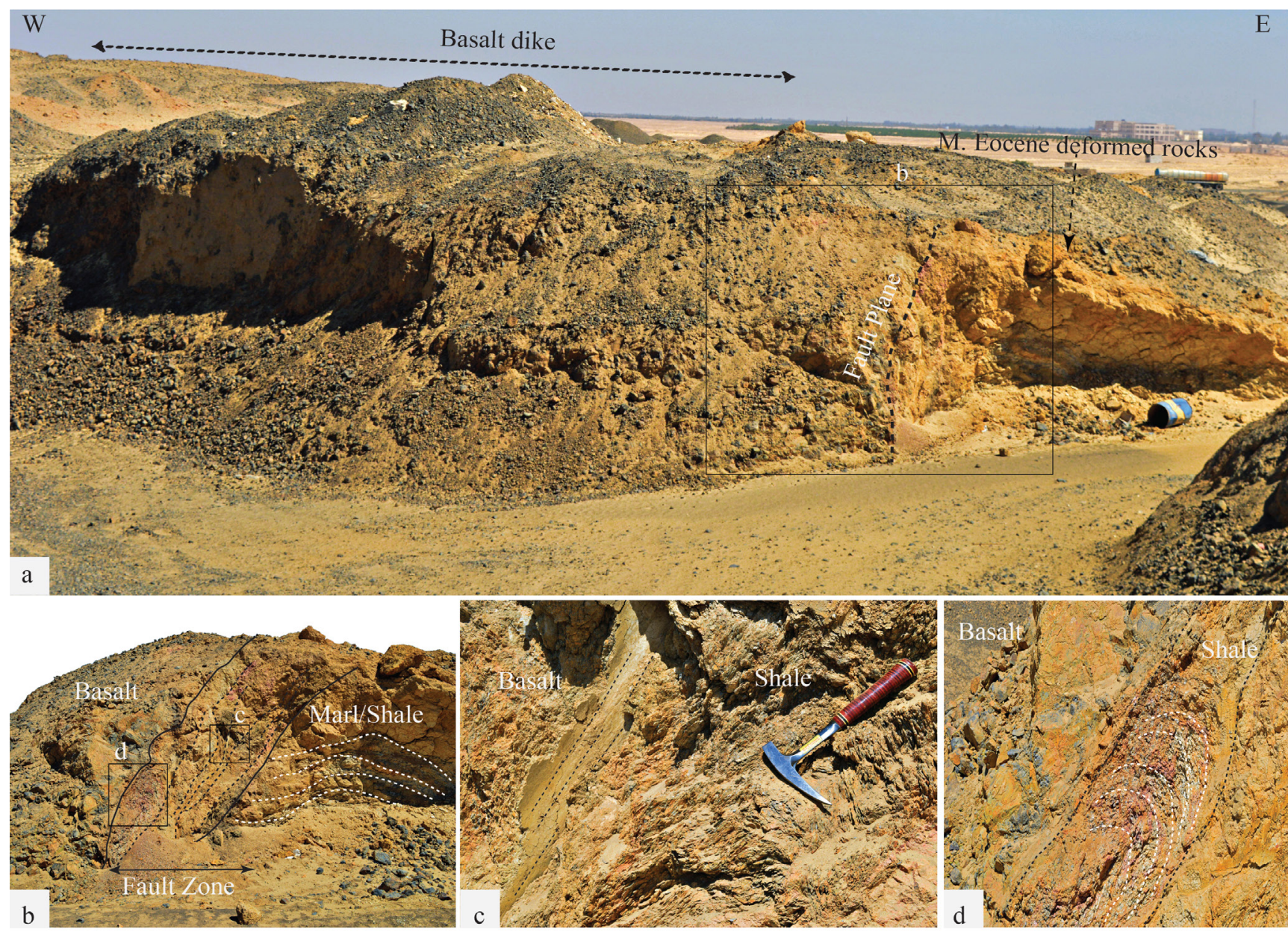

Fig. 4.11. The River Nile rift-related Volcanism, Western Nile, Bahnasa. Basalt eruptions along NW-oriented faults (a). Brittle-ductile deformation of the M. Eocene carbonates and marls with slickenlines showing normal dip-slip movement along the faults. The age of basalt in this locality according to K/Ar age-dating of the present work is $22 \mathrm{Ma}$, see Table 1; Sample (BHN-W-1). 


\section{Chapter 5 The River Nile Rift}




\section{Introduction}

The Nile Valley is characterized by a broad diffusion of extensional strain on both eastern and western shoulders (Fig. 5.1, see Fig. 1.4). This strain was accommodated by hundreds of riftrelated structures such as normal faults and related-folds as well as rift-related basalt dikes that intruded the entire length of the Nile's shoulders. Most of these structures and volcanic features are of NW and NNW trends. The central and northern shoulders of the river show occasional accumulations of syn-rift Oligocene gravels and sands that are hosted by longitudinal faultbounded troughs and shallow grabens of NW and NNW orientations (see Fig. 2.1 \& Fig. 2.2). These rift-related clastics are also found filling some inverted channels crossing the eastern and western Eocene carbonate plateaux (Fig. 2.6).

According to Youssef (1968), the major structural elements of Egypt such as faults, fractures and folds can be categorized into groups of different orientations, among them are two main fault trends; the $\mathrm{N} 35^{\circ} \mathrm{W}$ Red Sea-Gulf of Suez and the N15 $5^{\circ}$ Gulf of Aqaba. Fractures and Faults of these strike orientations, in addition to the N-S trends in the southernmost parts of the Nile Valley near Aswan, have strongly controlled the orientation of most of the river valley segments along its course. Akawy and El Din (2006) reported that Wadi Qena to the east of the river and some parts of the Nile Valley itself are being affected by low-degree active tectonics where the main fault trends (NW-SE, N-S, NE-SW) are probably still active.

The entire NW-trending Nile rift that this study suggests is $\sim 800 \mathrm{~km}$ long where each segment measures $\sim 250 \mathrm{~km}$ length and varies in width from $\sim 60 \mathrm{~km}$ at the southern part of the rift to $\sim 150 \mathrm{~km}$ to the north, where the rift extends and diffuses to affect wider shoulders to the east and west (Fig. 1.4). The rejuvenation of the Precambrian and Cretaceous structures during the Late Paleogene-Early Neogene extension controlled the evolution of the NW Nile rift, the river and its drainage system as well as the orientation, structural architecture, and arrangements patterns of the faults and folds on the rift shoulders. The amount of extension/deformation decreases northwards along the course of the river. The Nile rift and its grabens are characterized by a zigzag fault pattern, composed of NW, N-S to NNE-, E-W, and WNWtrending fault systems (Fig. 5.1 \& Fig. 5.2). 


\subsection{The Late Paleogene-Early Neogene Nile Rifting}

The interpretation of both gravity and magnetic models, as well as surface mapping of different structures, revealed the existence of extended shallow rift segments along the eastern and western flanks of the present-day Nile Valley (see Chapter 2). This study proposes a Late Paleogene-Early Neogene rifting phase that was developed at the longitudes of the River Nile (RN) with NW to NNW trends as the result of the Oligocene horizontal extension accompanied plate divergence between the African and Arabian plates, and opening of the Red Sea-Gulf of Suez rift basins in the East. The structures of the central and northern areas are characterized by NNW trends, i.e. parallel to the main orientation of the Red Sea and Gulf of Suez rift structures. While the orientation of the southern segment structures show anticlockwise rotation relative to the main $\mathrm{NNW}\left(\mathrm{N} 35^{\circ} \mathrm{W}\right)$ trend of the Red Sea, and most of them have $\mathrm{N} 45^{\circ} \mathrm{W}$ trends (see Fig. 2.11 \& Fig. 4.1). This can be attributed to the reactivation of the major Proterozoic transcurrent shears of the NW-trending sinistral Najd fault system.

This extensional tectonism has, in turn, resulted in reactivation of the older Cretaceous rift basins and major shear zones of the Nile Valley area in southern and central Egypt in addition to initiation of newer overlying shallow rift segments with faults, grabens, syn-rift clastics and volcanic intrusions of Oligo-Miocene age $\sim 25-23$ Ma. Some of the Precambrian basement shear zones along the RN acted as triggers or pervasive tectonic fabrics along which the bounding faults of the Early Cretaceous and younger rift segments were either initiated or reactivated, for instance the Hodein-Kharit major shear zone of NW orientation (Najd fault trend), which prolong through the southern parts of the Eastern Desert. Some other examples are the E-W and ENE-trending shear zones that extend along the latitudes of Qena and Assiut, and acted as transfer zones for the propagating rift segments during the Early Cretaceous and Late Paleogene-Early Neogene rifting (Fig. 4.1).

Each of the NW-oriented Late Paleogene-Early Neogene rift segments along the Nile Valley was probably developed as an immature or incomplete asymmetric half-graben basin or subbasin, and was populated by the majority of extensional faults on one side with flipping of their polarities and densities across the orthogonal or oblique transfer zones (Fig. 5.1). The $\mathrm{N} 60^{\circ} \mathrm{E}$ rift-orthogonal extension of the NNW-oriented Red Sea-Gulf of Suez rift system in the east 
might have not significantly reactivate the relatively oblique NW-oriented Cretaceous rift basins along the Nile Valley, particularly in southeastern Egypt (see Fig. 4.4). This might suggest complex tectonic controls of the inherited Cretaceous and Precambrian basement fabrics on the reactivation of structures in the southern and central rift segments as a response to the direction of the regional extension. The initiation and reactivation of rift basins are controlled basically by the relative orientations of the regional extension and the pre-existing structures. The NW Cretaceous basins in central and southern Egypt were reactivated by an oblique phase of extension during the Late Paleogene-Early Neogene rifting (see Fig. 4.7 \& Fig. 4.8). As a consequence, the proposed rift along the Nile Valley was probably aborted at a very early stage.

The main objective of this study is to focus on three major rift segments and their sub-basins that are developed along the RN in NW to NNW trends, which are transferred and terminated by three highly oblique transfer/accommodation zones. The Ancestral Nile river(s) have probably established their courses along the extensional faults and fractures of these rift segments. The geometry and distribution of the older and present-day drainage systems of the Nile have also been strongly influenced by the structures and morphotectonic features of both the main NW-trending rift segments and the oblique transfer zones and cross elements. The transfer zones and cross elements were formed diagonally to the course of the Nile Valley, and nucleated along E-W to ENE-trending Precambrian basement and Cretaceous shear zones, ridges and extended fault-fold belts. These oblique structures, relative to the main course of the rift, have probably persisted as stable structural ridges or basement highs during successive rifting phases since the Early Cretaceous. Examples are the basement high of the Great Qena bend in the south, and the northern inverted Kattaniya ridge, which possibly terminated the northward propagating rift (see Fig. 2.12 \& Fig. 2.13).

The transfer segments might have reactivated as transtensional or transpressional shear zones and strike-slip faults, for instance, the E-W and ENE-trending strike-slip faults of Wadi Assiuty and El Bahariya-Fayium major fold-fault belt. Both examples of the transfer zones across the Nile Valley can be interpreted on the gravity and magnetic anomaly models as well as on the surface topographic maps and digital elevation models (see Fig. 1.3, Fig. 2.11 \& Fig. 4.4). Across the E-W to NE extending transfer zones, each of the orthogonal NW-oriented rift 
segments has different structural architecture and tectonic evolution. In general, the northern and southern segments are bounded mainly on the east by major rift-border faults, while the central one is populated by faults, related-folds, and fractures on the west (see Fig. 4.3, Fig. 4.7 \& Fig. 4.8).

The initial extensional tectonism that formed most of the rift segments, their sub-basins and various structures and morphotectonic features has probably begun in the Early Cretaceous or may be earlier (see Fig. 4.3, Fig. 4.6, Fig. 4.7 \& Fig. 4.8) The early rifting phases in the southern segment witnessed a deep burial of the both Nuqra and Kharit rift basins relative to KomOmbo basin with a prominent thickening of the earliest Cretaceous syn-rift sediments, while the three basins were probably subsided at the same rate during deposition of the overlying sediments (Mostafa et al., 2016). Movements along major fault trends continued intermittently into the Neogene. The successive extensional phases resulted in a heterogeneous structural style and reactivation/formation of faults of different trends along the deep-seated faults, rotated blocks, rift shoulders and intra-basinal highs and troughs.

The Ancestral Nile carved its pathway and canyon in the south along the NW-oriented rift basins of Kharit and Nuqra to the west of the present-day river valley, and KomOmbo to the east. Further north, Assiut and Beni Suef basins are located in the west of the central and northern Nile Valley with a dominant NW to NNW orientation. Based on the analysis of both gravity and magnetic anomaly models as well as the mapped surface structures, this study interpreted a rift segment located to the east of the central Nile Valley between Sohag and Assiut (Fig. 4.8). The subsurface image of this area was not well documented due to the lack of seismic and borehole data. The basins along the central and northern latitudes of the Nile were also formed during the Early Cretaceous rifting phases and reactivated consecutively during successive extension phases in the Paleogene and Neogene. 


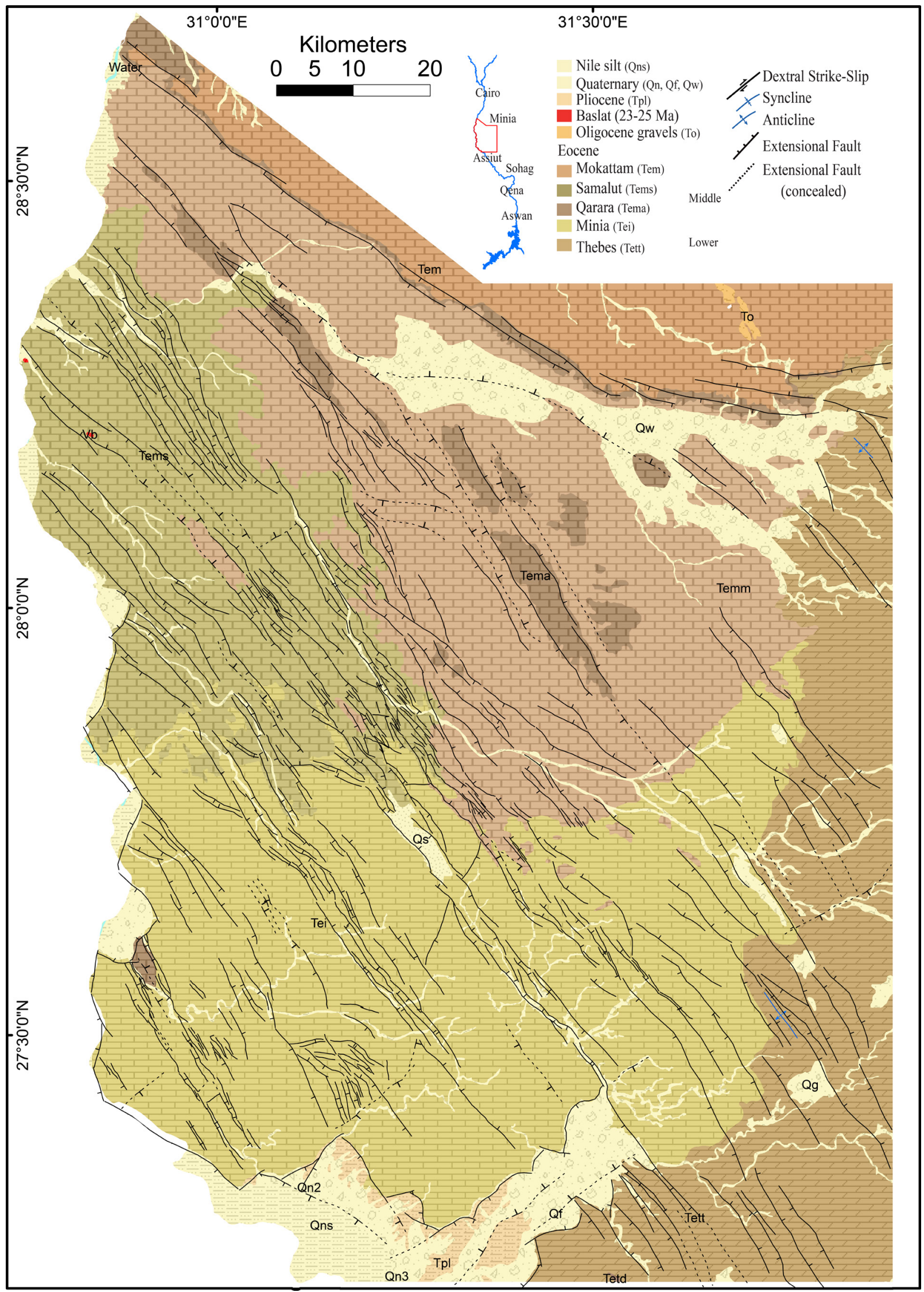

Fig. 5.1. Structural map of the northeastern sector of the Nile Rift System, the western area between Assiut and Minia. The map shows the prevailing $N N W$ - and $N W$-striking extensional faults that bound linear narrow grabens. 


\subsection{The Nile Rift-Related Structures}

The interpretation of surface and subsurface datasets shows structural and tectonostratigraphic heterogeneity of the mapped area that noticeably addresses two main structural provinces along the Nile Valley. The Southern Province has a regional northwestward dipping slope, i.e. toward the Nile valley, and shows a predominance of the NW-trending Early Cretaceous rifting tectonics that controlled the structural architecture and geometry of the ancestral Nile Valley as well as the distribution densities and orientations of fault segments, fractures and drainage systems. This province shows a shallow and less penetrative print of both the Late Cretaceous Syrian Arc tectonics and the Oligocene reactivated rifting phase. It is composed mainly of fractured Precambrian basement and Cretaceous exposures, and relatively fewer occurrences of the Oligo-Miocene rift-related faults, folds and volcanic intrusions (see Fig. 1.5). The eastern and northern parts of this province show numerous extensional faulting, while the western extents display relatively mild deformation (Fig. 5.1 \& Fig. 5.2). However, the southwestern parts include most of the tertiary volcanic eruptions in the southern province. Several riftparallel syncline folds are mapped in the Cretaceous sediments of the hangingwalls of the main troughs in the southern structural province.

The Northern Province shows widespread extensional deformation with the prevalence of hundreds of NNW-oriented extensional faults, fractures and related-folds that extend along the grabens and fault blocks of the Nile Valley (Fig. 5.3, Fig. 5.4 \& Fig. 5.5). It is made up mainly of Lower-Middle Eocene carbonates that host several occurrences of the Oligo-Miocene synrift clastics and basaltic volcanics. The distribution and geometry of the NNW-trending faults and their hard-linkage E-W and NE-oriented transfer segments form a structural pattern in the northern Nile province that resembles the architecture of the southern and central basins of the Gulf of Suez (see Fig. 4.5). Reactivation of the Late Cretaceous E-W to NE-striking faults effectively controlled the development and location of the transfer zones that controlled the segmentation of this province. The northern structural province is bounded by NE fold-fault belts extending along the Bahariya-Fayium district were possibly reactivated along inherited structures of the Early Cretaceous rift faults and the Late Cretaceous Syrian Arc. This area, however, hosts the majority of the Oligo-Miocene syn-rift sediments and rift-related basalt intrusions and flows. 

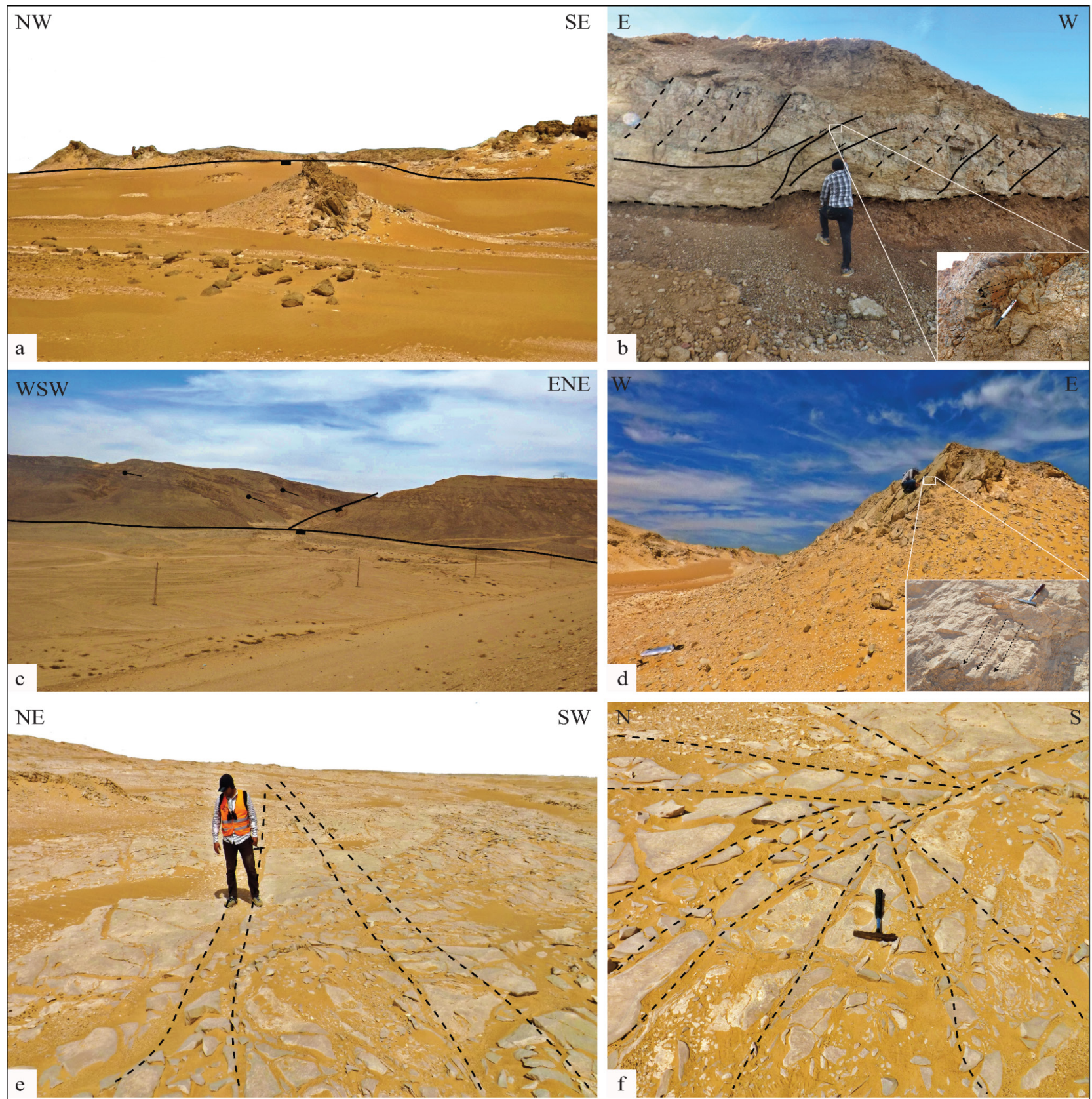

NNW

Relay ramps

SSE

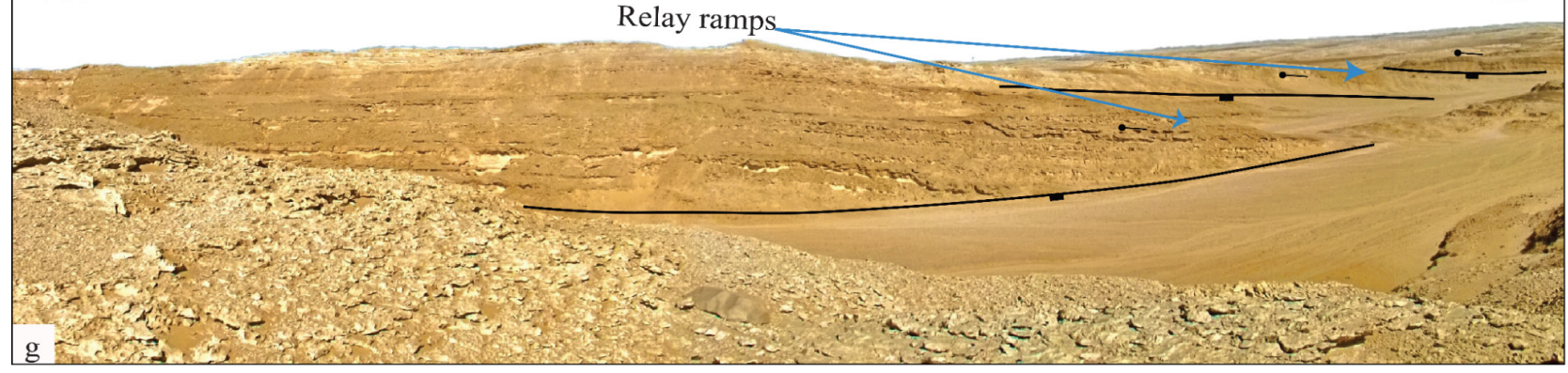

Fig. 5.2. Field occurrences of rift-related structures along the Nile Rift System. a) NW-striking extensional fault cutting through Middle Eocene rocks of the Thebes Formation, west Assiut. b) E-W oriented fault scarp in Wadi Assiuty, showing the orthogonal $N W$-striking faults with slickenlines indicating an oblique-slip displacement. c) Rift-parallel (NW) and rift-orthogonal (ENE) normal faults with rotated-fault blocks along the eastern shoulders of the Nile Valley, east Minia. d) A vertical plane of NNW-striking extensional fault with normal dip-slip kinematic indicators. d) Strongly fractured Lower Eocene Drunka limestones with NW to $N N W$ dominant strike orientations. e) Subsidiary fractures of multiple orientations reflecting the possible radial extension of an early-rifting phase. f) En-échelon fault arrangement of $N N W$-oriented extensional faults with rely-ramps in-betweens. 


\subsubsection{Faults}

The majority of the mapped surface/subsurface faults along the shoulders of the Nile Valley are characterized by NW to NNW trends that controlled the structural setting, architecture and tectonic evolution of the proposed Late Paleogene rifting of the Ancestral RN (Fig. 5.1, Fig. 5.4, Fig. 5.5 \& Fig. 5.6). The NNW trend is commonly known as "Clysmic Trend" in the Red Sea-Gulf of Suez rift area, which also controlled the structural architecture and tectonics of these rift basins. E-W, ENE-, and NE-striking fault arrays are abundant in three main faultbelts and form the transfer zones of the Nuqra trough, the Qena dome, and Wadi El-Assiuty shear zones in addition to the northern Bahariya-Fayium terminating fault- fold belt. These fault belts separate the three structural provinces in the Nile Valley area and transfer both the rift-border faults and the rift-related volcanism on the eastern and western shoulders of the Nile. The measured slickensides along some fault planes indicate both normal dip-slip and oblique-slip displacements with dextral shear sense (Fig. 5.2 b \& d). The rift-oblique/orthogonal E-W to NE-trending faults act as the transfer linking segments for the rift-parallel NW and NNW faults along the northern and southern boundaries of most of the fault blocks in the main graben of the Nile Valley and along its shoulders, and form a characteristic zig-zag fault patterns. The surface short segments of the fault arrays commonly exhibit left- and rightstepping and relay arrangement patterns with local transfer faults (hard-linkage) or rely ramps (soft-linkage) in between (Fig. 5.2 g). This might suggest that these segments are the surface expression of the oblique and horizontal movements along deep-seated major strike-slip faults particularly along the main transfer zones such as Wadi El Assiuty and Bahariya-Fayium fault belts.

The half-graben blocks of the southern Nile rift segment are characterized by SW-dipping strata that are rotated by NW-striking faults of south-eastward throws (see Fig. 4.3). Most of the faults in this area have synthetic SW dipping planes with fewer occurrences of antithetic minor segments. The southern faults show varieties of $20-30 \mathrm{~km}$ lengths with vertical displacements at a scale of $100 \mathrm{~s} \mathrm{~m}$. These faults uplifted the northeastern and southwestern margins of the Precambrian basement rocks of the footwall blocks against Cretaceous sediments in the main basinal troughs. Further to the northeast, $10-15 \mathrm{~km}$ faults extend in the eastern parts of the southern rift segment and cut through Cretaceous sediments with a 
considerable northward decrease of vertical displacements (see Fig. 1.5 \& Fig. 2.11). Moving further north, the Precambrian basement and Upper Cretaceous exposures are replaced gradually by Lower-Middle Eocene rocks at the western flanks of the faults in a clear indication of progressive northwestward loss of displacement along the faults strikes. Toward the river, longer NW-striking faults bound Eocene exposures of both eastern and western footwall blocks of the valley and trapping the Neogene clastics of the Nile.

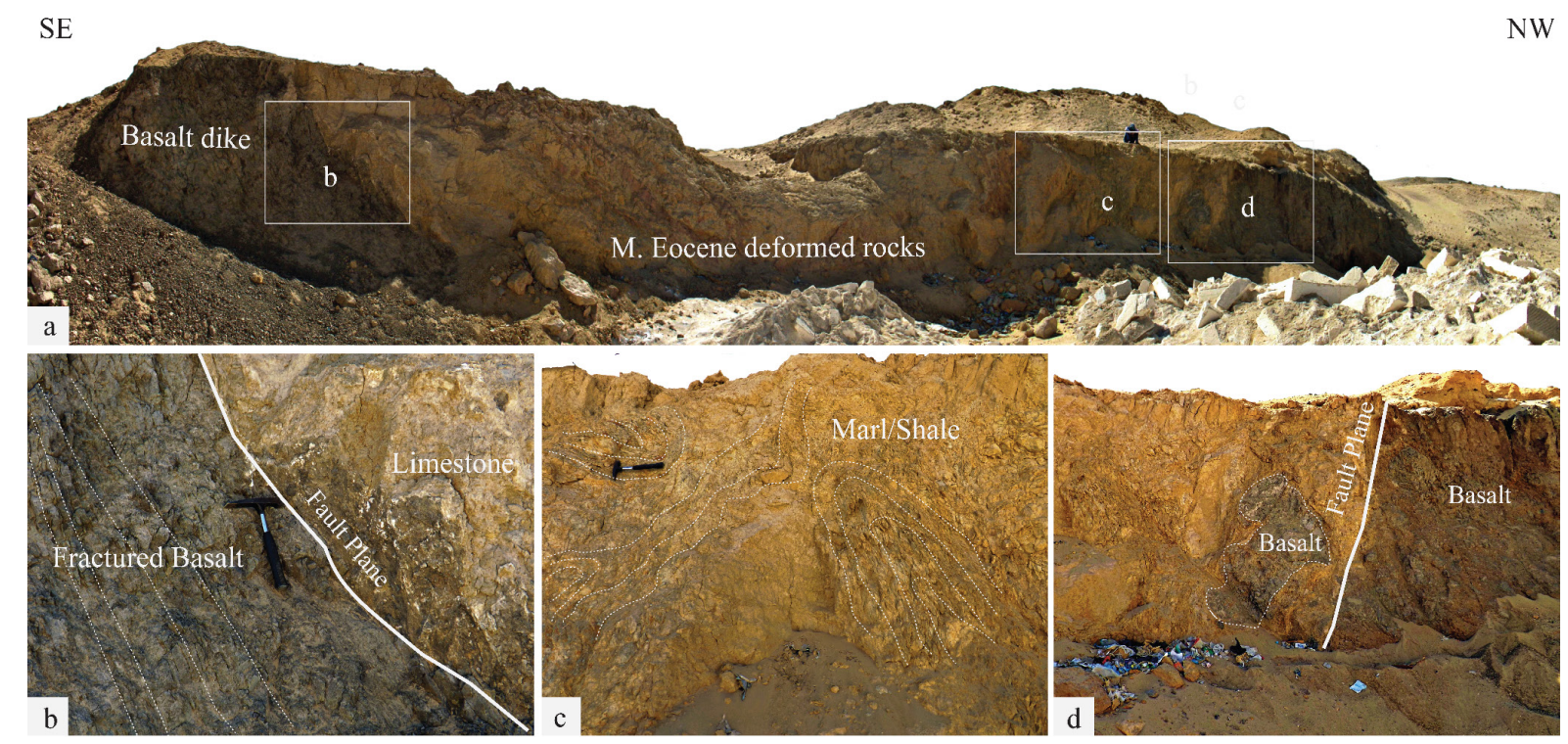

Fig. 5.3. Nile Rift-related volcanism, Samalut Mountain, eastern Nile, west Minia. a) Basalt fissure eruptions and flows along NW-oriented faults cutting through Middle Eocene rocks. b) Fractured Basalts along NW-striking fault zone. c) Strongly deformed Middle Eocene marls and carbonates sediments as a result of the rift-related extension and basalt eruptions, notice the brittle-ductile syn-rift deformations and drag-folding in the pre-rift Middle Eocene marls and shales. $d$ ) Basalt inclusions along the fault damage-zone within the Middle Eocene marls. The age of basalt in this locality according to K/Ar age-dating of the present work is 20.4 Ma, see Table 1; sample SMS-2.

Further to the north and west, within the central and northern rift segment and along grabens and fault-blocks on the eastern and western shoulders of the Nile Valley, the rift-parallel faults show a remarkable increase in their frequency (hundreds of fault segments) with a significant drop in the amounts of throw along their prevailing NNW-oriented strikes (Fig. 5.4, Fig. 5.5 \& Fig. 5.6). To the west of Assiut and Sohag localities, interference and linkage of NW- and NNW-striking faults form characteristic polygonal fault patterns that are similar in shape to the dewatering structures, which form in extensional rift basins (Fig. 5.4). Most of these faults have steep to vertical planes that dissect Lower and Middle Eocene rocks in their hanging and footwall blocks with minor amounts of vertical displacements, while others bound elongated linear grabens and shallow troughs, which accommodated relatively thin sequences of Oligocene syn-rift clastics. 
Several fault segments extend for tens of kilometres along the northern Nile Valley with a few meters of vertical displacements (Fig. 5.2). To the northeast of Minia and Beni Suef, the displacement across these faults decreases gradually through a stratigraphic separation of Middle Eocene rocks in the up-thrown and down-thrown blocks (Fig. 5.1). These observations emphasize the northwestward increase of both the population densities and lengths of the riftparallel faults at the expense of their vertical displacement, which in turn indicates the stress/strain dissipation along the entire area of the central and northern Nile rift. Further east and west of the mainstem of the Nile rift, the frequency of faults decreases significantly with a considerable reduction in the amounts of vertical throws (Fig. 5.1, Fig. 5.5 \& Fig. 5.6).

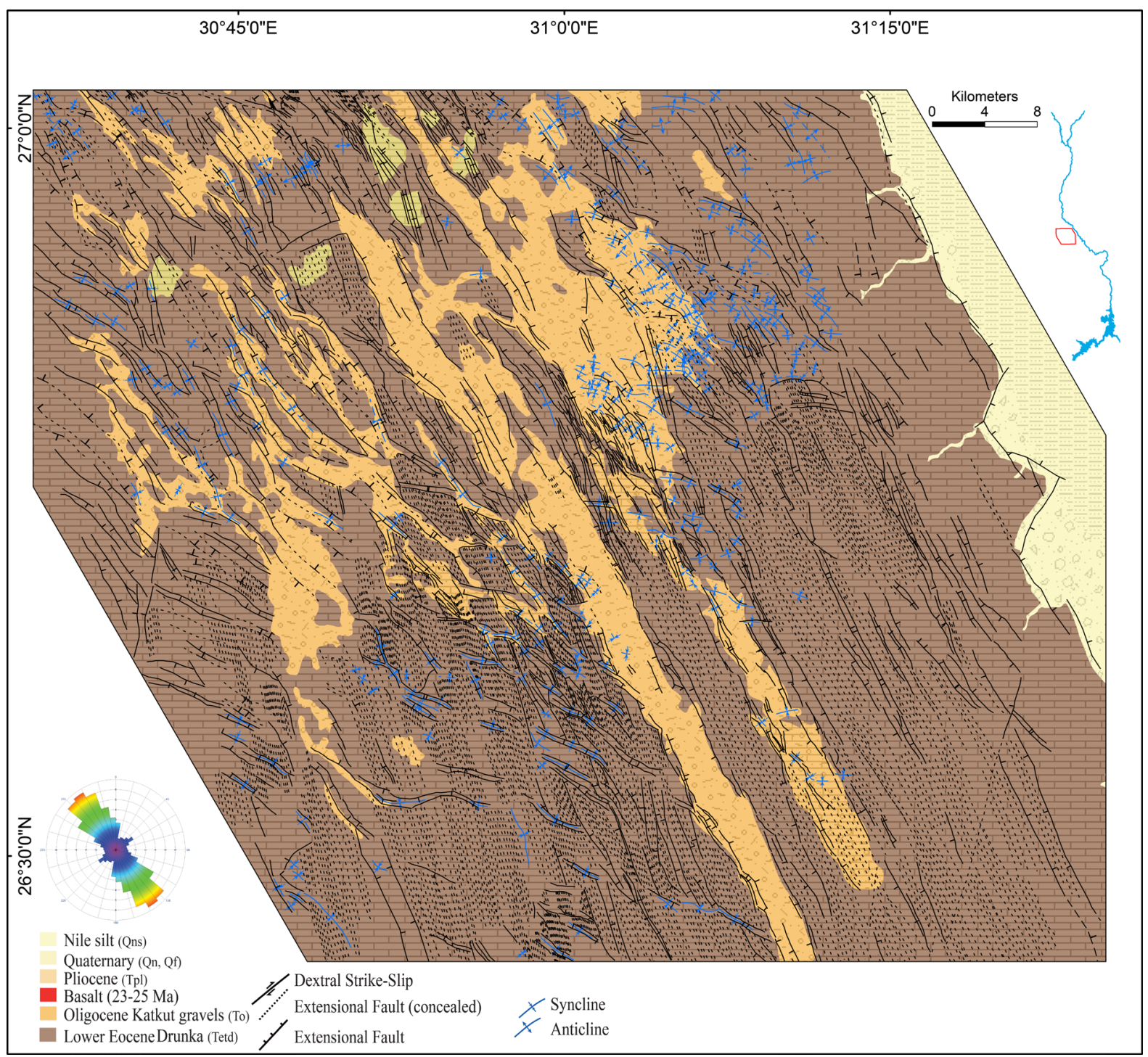

Fig. 5.4. Structural map of the western sector of the Nile Rift System, the western area between Sohag and Assiut. The map shows the prevailing $N N W$ - and NW-striking fractures and extensional faults forming shallow grabens that host the earl synrift Oligocene gravels and extensional fault-related folds. Interference of the two fault trends form characteristic polygonalshaped graben and horst fault blocks. 


\subsubsection{Folds}

The Nile Valley area exhibits a typical extensional rift system where synclinal and anticlinal folds are found related to both vertical and horizontal movements along the hangingwall and footwall blocks of the associated normal and oblique fault segments (Fig. 5.5, Fig. 5.6 \& Fig. 5.7). The kinematic criteria and structural development of the extensional fault-propagation folds have been widely described in several extensional rift basins (Schlische, 1992; 1995), and particularly in the Red Sea-Gulf of Suez rift systems (Moustafa and El-Raey, 1993; Khalil and McClay, 2002; 2017). The majority of the Nile rift-related folds have axial traces extend parallel or semi-parallel to the rift-related faults and fractures that have dominant NNW strikes, while few others are cut and offset by these faults (Fig. 5.7 a, b \& c). In terms of tectonostratigraphic evolution and structural geometries, two main groups of folds can be recognized in the southern and northern structural provinces of the proposed Nile rift, which were indicated earlier.

In the southern structural province, south to the Great Qena Bend, several NW-SE large-scale extensional fault-related folds were traced in the exposed Cretaceous sediments in the main hangingwall troughs of the southern rift segment along the Nile Valley. These folds were possibly formed during the Early Cretaceous rifting phase that created the Kharit and Nuqra half-graben basins and might have been reactivated as a result of the Late Paleogene extension and due to rejuvenation of vertical movements along the basinal and rift-bounding faults, which resulted in brittle-ductile deformation of the younger sediments (see Fig. 4.3).

The other group of folds is of different structural setting and evolution time whereas numerous small-scale folds of both NNW-SSE and NW-SE orientations are found disturbing the slightly dipping and flat-lying Eocene carbonate strata of the central and northern plateaux of the Nile (Fig. 5.5 \& Fig. 5.6). The geometry and orientations of the fold occurrences in the Nile's central and northern rift segment are strongly controlled by the dominant trends of the surrounding Oligocene rift-related faults, while their distribution densities are influenced by both the mechanical properties of the rocks as well as the population frequency of faults and fractures. 


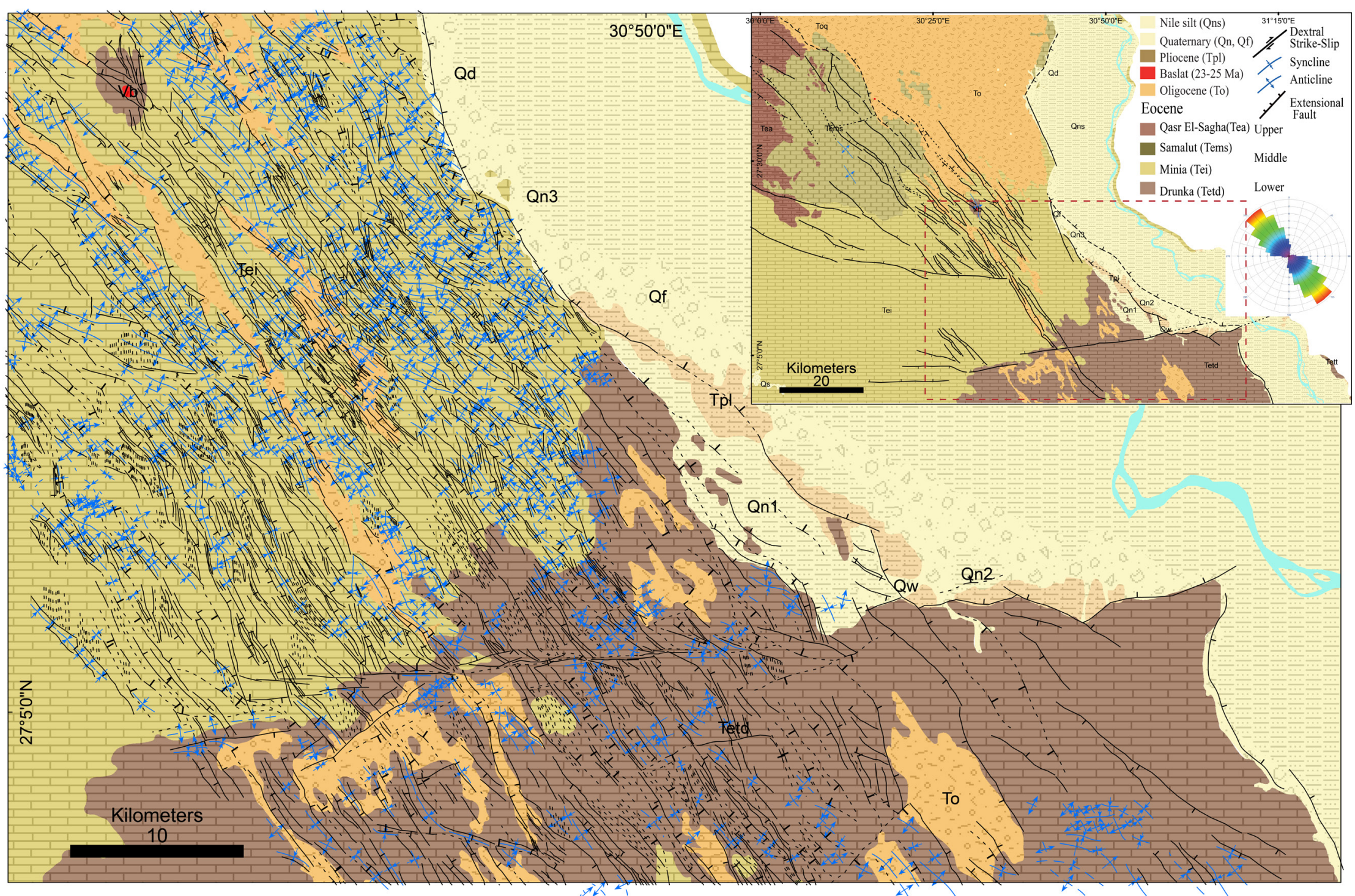

Fig. 5.5. Structural map of the western sector of the Nile Rift System, the western area between Assiut and Minia. The map shows the prevailing rift-parallel trends, NNWand NW. of the extensional faults and related folding (hundreds of anticlines and synclines of blue color). The Middle Eocene rocks of Minia Formation host the majority of these rift-related folds as a good indicator for the role of mechanical stratigraphy and different rheology of rocks on their brittle-ductile deformation. The Minia limestones are relatively less competent than the cherty hard-carbonates of the southern Lower Eocene Drunka Formation. 


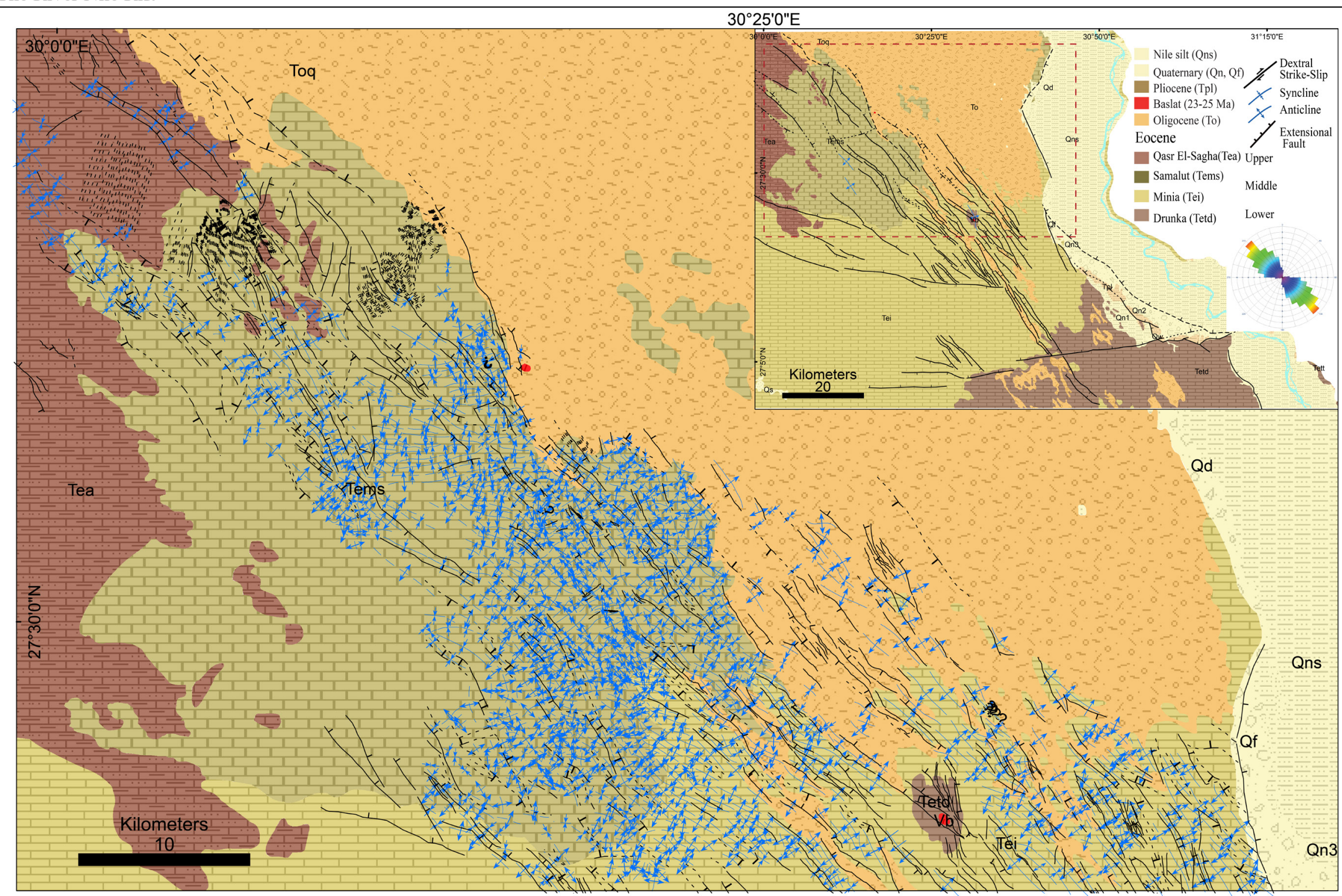

$30^{\circ} 25^{\prime} 0^{\prime \prime} \mathrm{E}$

Fig. 5.6. Structural map of the western sector of the Nile Rift, the western area of Moghra Graben. It shows the strongly deformed shoulders of the Moghra with dominant NNW- to $N W$-striking fractures, extensional faults and related folding. The change of the density and predominant orientation of the extensional faults show a clear influence on the geometry and distribution of the associated folds, which display a heterogeneity between both the rift-parallel and rift-orthogonal trends, i.e. NW and NE trends, respectively. 

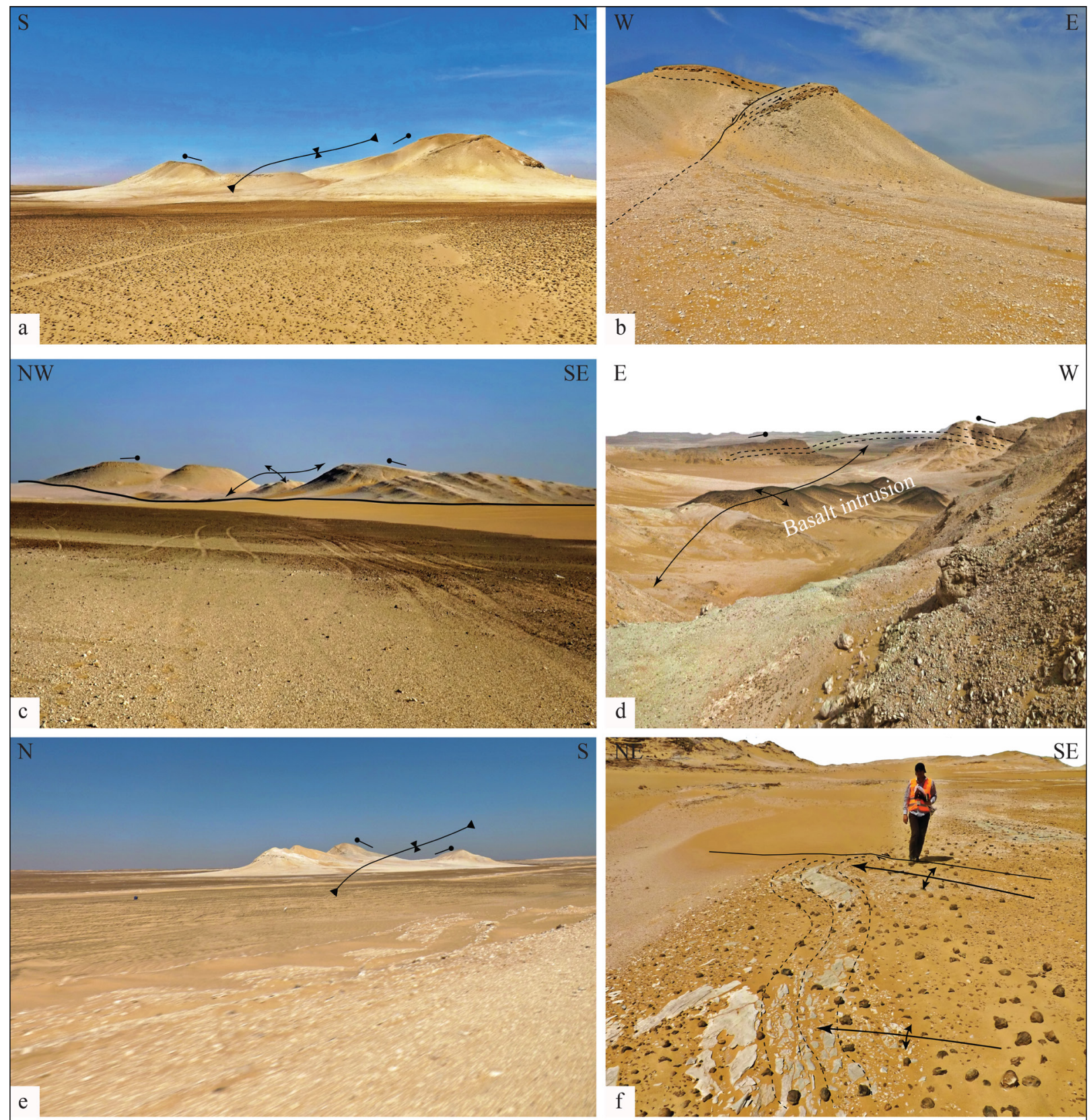

W

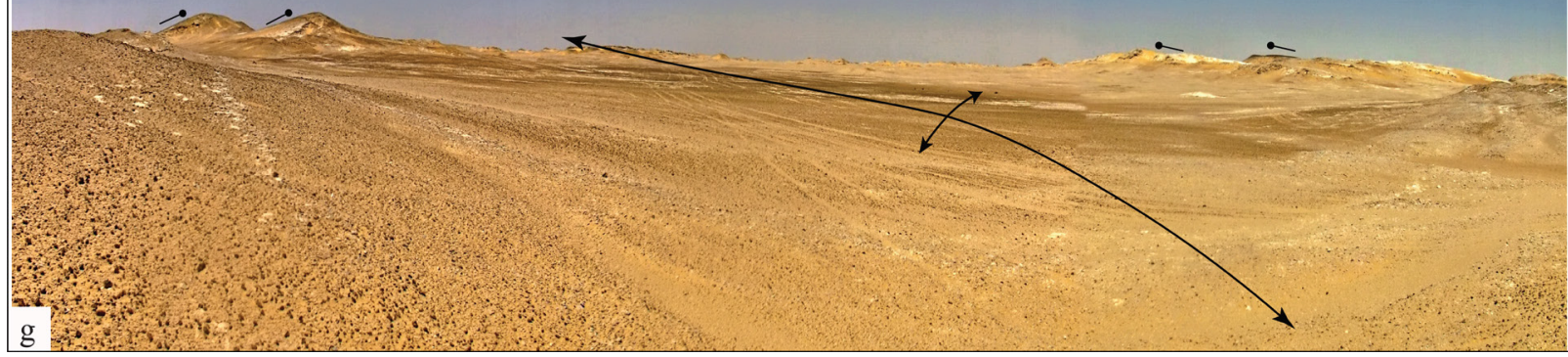

Fig. 5.7. Field Occurrences of the Nile Rift-related folding. a) NW-oriented syncline in Middle Eocene Minia carbonates. b) Faulted syncline (with fault-parallel axial trace) showing that the folding postdated or was contemporaneous with the development of the extensional faults during the Nile rifting. c) NE-trending Anticline in Lower Eocene Drunka limestones bounded by NW-striking extensional fault (with fault-orthogonal axial trace). d) Forced NW-oriented anticline formed by the uplift of the basalt intrusion along NW-striking dikes. e) Syncline with fault-oblique axial trace in Middle Eocene Samalut limestones. f) Folding formed by horizontal movements along NE-striking dextral strike-slip faults, north to Wadi Assiuty Shear Zone. g) Elongated NW-oriented Anticline along the western shoulders of the Moghra Graben. 
The folds show noticeably much higher frequencies along the western shoulders of the valley and particularly in the less competent Middle Eocene west of Assiut relative to the more competent Lower Eocene rocks further south and east (Fig. 5.4, Fig. 5.5 \& Fig. 5.6). Based on their geometrical and structural relationships with the controlling faults, these folds can be interpreted as "extensional fault-propagation folds" that were developed contemporaneously with the Late Oligocene rifting in the Nile Valley area. Tewksbury et al. (2017), on the other hand, interpreted most of the folds in the Eocene limestones of the western desert as "nontectonic sag synclines". They suggested that these synclinal folds were formed as a result of hypogene karstification that is related to extensive fluids dissolutions associated with basaltic intrusions, while other mechanisms such as modern and paleo-karst collapse, subsurface dissolution of evaporites mechanisms wouldn't explain the origin of these synclines based on their timing of formation and the underlying rocks.

This study recognized and mapped several plunged and doubly plunged folds in fieldwork studies in the Western Dessert of the RN along the western extents of Sohag, Assiut and Minia governorates. High-resolution digital elevation models, Sentinel-2 and GoogleEarth satellite images were imported in ArcGIS to digitize and statistically analyse hundreds of syncline and anticline folds along the proposed rift segments along the Nile Valley as well as through the crossing transfer zones. The majority of folds are found in Lower and Middle Eocene rocks of the western central and northern rift segments, with much fewer occurrences to the east. However, we mapped several synclinal folds in the Upper Cretaceous rocks of the Kharit and Nuqra grabens in the south-eastern rift basins. Some minor folds were also mapped within the Oligocene rift sediments in the entrance of the ancestral delta to the west of the present-day river (Fig. 5.6).

Most of the mapped folds in the western Eocene plateau are of minor amplitudes and gently dipping limps $\left(20^{\circ}-30^{\circ}\right)$ (Fig. 5.7). The folds are frequently of small scale with $\sim 2-3 \mathrm{~km}$ length and $\leq 1 \mathrm{~km}$ width, and almost of NW and NNW-trending axial traces. These folds show different geometrical relations with the associated faults where most of them are parallel to the dominate NW and NNW orientations of faults and fractures, while few others have axial traces oblique or normal to the associated faults. The later folds usually plunge either toward the minimum footwall uplifting (for anticline), or the maximum hangingwall subsidence (for synclines). Folds 
situate footwalls with axes perpendicular to the fault traces are usually plunging toward the structural and depositional lows. To the north, minor folds were formed in the incompetent upper Eocene sediments that are entrapped in the grabens and troughs of the Fayium depression.

The folds address variable geometries with their developing faults where their axial traces are parallel, oblique or normal to the fault strike. However, the majority of them have axial traces parallel or semi-parallel to the associated faults with dominant NW and NNW trends. Most of the faults extend for long distances with limited amounts of vertical displacements (Fig. 5.6). Therefore, the development of the faults-propagation folds might be also related to the reactivated extension along deep-seated faults. These folds can be geometrically differentiated into three categories (see Fig. 5.5); 1) Longitudinal folds that have axial traces parallel to the NW- to NNW-oriented faults (e.g. Fig. 5.7 b, f \& g). 2) Transverse folds of axial traces perpendicular or at high angles with the strike of associated faults (e.g. Fig. 5.7 c). These folds are generated by variation of displacement (subsidence and uplifting) along the adjoining fault (Schlische, 1995). 3) Oblique folds with axial traces at an angle with the fault trace (e.g. Fig. 5.7 e), and the E-W oriented anticlines and synclines in Upper Eocene rocks associated with NWstriking normal dip-slip fault.

\subsection{Nile Rift Clastics}

The Late Paleogene rifting in Egypt began in the latest Oligocene/earliest Miocene (Bosworth et al., 2012). The Oligocene global sea-level fall (Haq et al., 1987) as well as the regional uplifting processes that accompanied the intracontinental rifting in the Red Sea-Gulf of Suez and Nile Valley resulted in widespread exposure, extensive erosion and karstification of the EoceneCretaceous outcrops in the Eastern and Western Deserts as well as the development of fluvial depositional systems and formation of rivers. Consequently, a peak highstand during the Oligocene time deposited continental fluviatile sediments overlying unconformably the shallow marine Eocene carbonates in central and northern Egypt (see Fig. 1.5, Fig. 1.6, Fig. 1.7 g-h \& Fig. 2.2). This was associated with the development of extensive erosional surfaces and palaeosols in the underlying stratigraphic units, and deposition of red beds and fluviatiledominated facies along the shoulders and basins of the Red Sea-Gulf of Suez rift system (see Fig. 4.6). Equivalent facies were also deposited along the west-central and northern and flanks 
of the Nile Valley and filled the main depression of the ancestral Moghra delta in the north Western Desert (Fig. 5.6).

The earliest "Late Oligocene-Early Miocene" syn-rift continental sedimentary sequences in the Gulf of Suez rift area composed mainly of basal conglomerates, gravels, and sandstones units in addition to thin intercalations of claystones and siltstones (Montenat et al., 1998; Darwish and El-Azabi, 1993; El Barkooky and El-Araby, 1999) (see Fig. 4.6). Similarly, extensional rifting tectonics and continental depositional environments controlled the development of early syn-rift clastics and fluvial sediments along the Nile Valley during the Oligocene that unconformably overlaid the Early and Middle Eocene Drunka and Thebes formations, respectively (Fig. 5.8). The NW- and NNW-oriented grabens and shallow troughs of the central and northern rift segments as well as the ancestral delta host most of the Oligocene gravels, red sandstones and conglomerates of the Nile rift (Fig. 5.4 \& Fig. 5.6).. These sediments were described as Katkut Formation in some occurrences to the west of the Nile Valley and were assigned to "Pre-Eonile or Late Oligocene" age (Issawi et al., 2009; Seif, 2015). The gravels and clastics postdate the Middle Eocene outcrops of the western Nile Valley (Fig. 5.8).

The sediments of the Katkut Formation in the southern extents of the central rift segment are considered as the oldest Nile rift-related Oligocene clastics. These coarse clastics-dominated sediments were accumulated as a result of sporadic erosional phases and fluvial depositional cycles controlled by relatively moderate tectonics and severe climatic changes. Thick accumulations ( $\sim 60-70 \mathrm{~m}$ ) of well-rounded gravels and cherty limestone and dolomitic clasts of deep reddish colours filled fault-bounded grabens and hangingwalls of NW-oriented fault blocks (Fig. 5.8). The Oligocene conglomeratic beds host pebbles and large boulders of the Lower Middle Eocene Drunka and Thebes carbonates. These observations might indicate that the gravels and clasts were transported by paleo-rivers for relatively long distances under severe exposure and erosive conditions associated with active syn-sedimentary rifting rather than a stable "in-situ" deposition. 


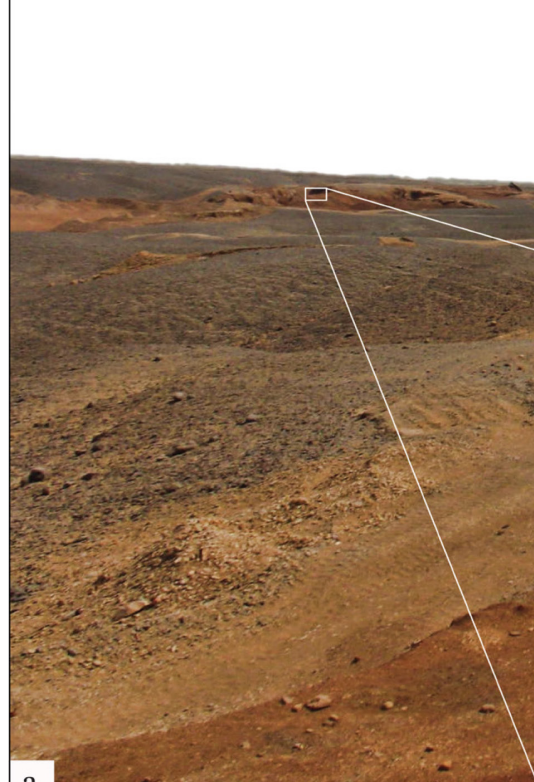

a
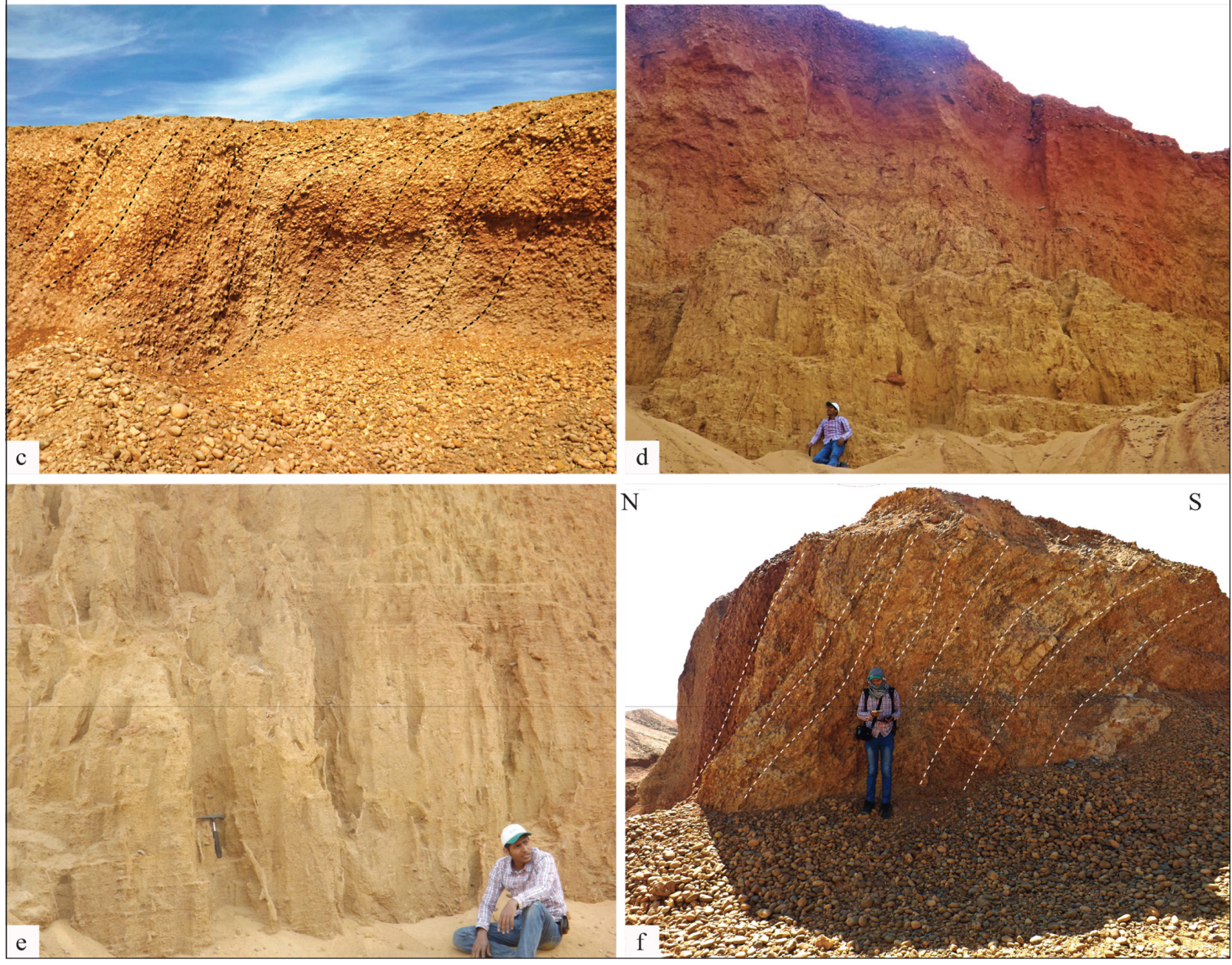

\section{Eocene (Drunka)}
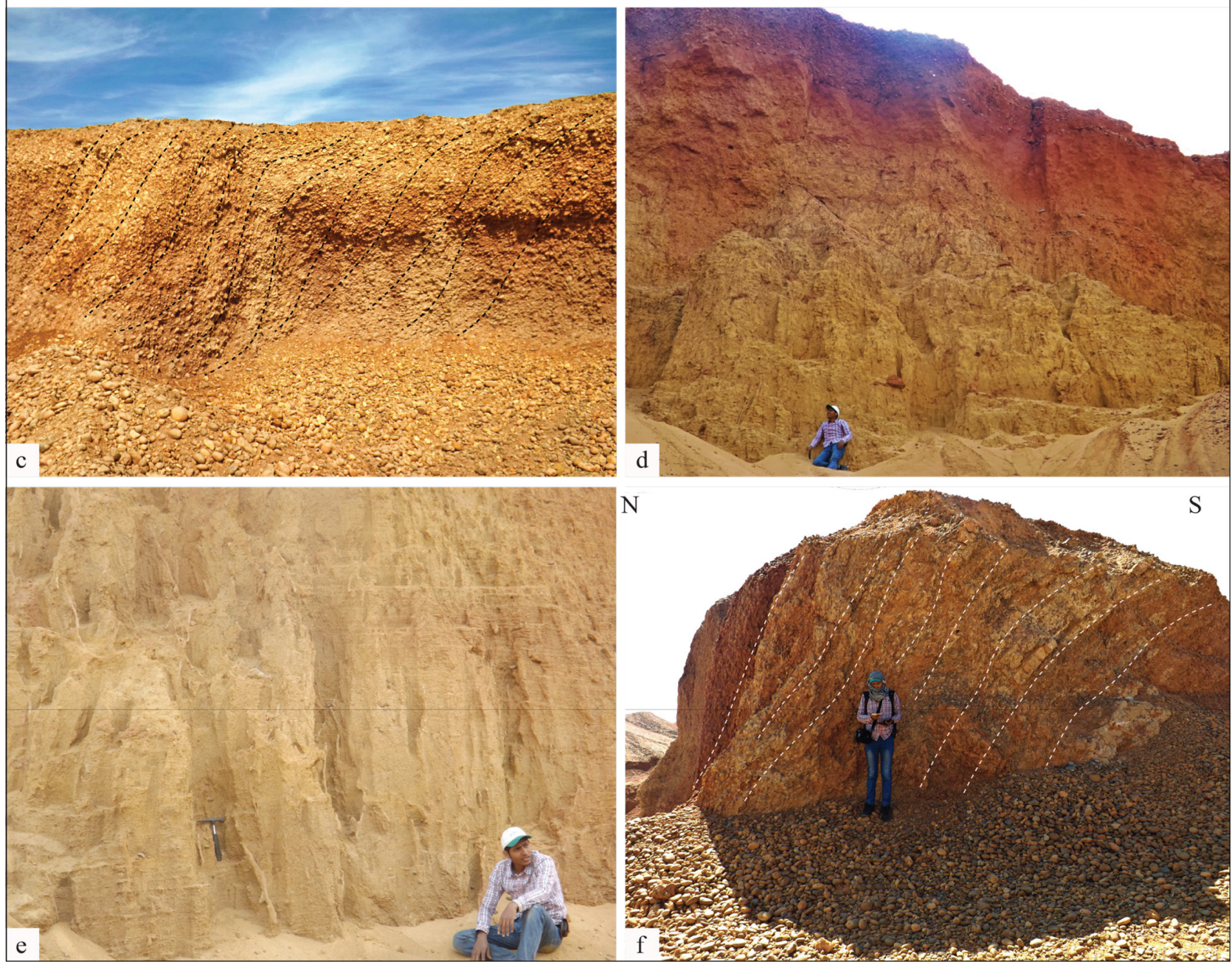

OLigocene gravels (Katkut)

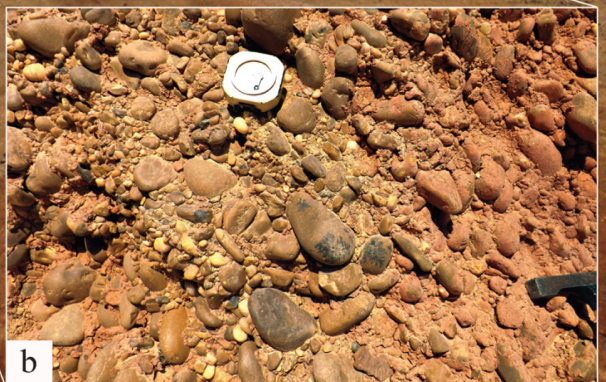

Fig. 5.8. Filed Occurrences of the Nile syn-rift Oligocene clastics. a) Example of the NW-oriented grabens, west of Sohag, which hosts the earliest syn-rift Oligocene clastics (Katkut Formation, equivalent to Gebel Ahmar and Qatrani formations to the north of the River Nile Rift System. b) Well-rounded gravels of the Katkut Formation. c) Imprecations of the Oligocene Katkut gravels that indicate a possible NNW to NW (rift-parallel) Paleo-flow directions of the old rivers. d) Oligocene fluviatile red sandstones and conglomerate beds, southwest of Sohag. e) Roots and plant remain of the syn-rift fluviatile sandstones. $f$ ) Tilted Oligocene sandstone and conglomerate beds along NW-striking normal fault, which indicates the syn-depositional extension of the early-formed rift basins. 
Moreover, the imprecation textures indicate dominant rift-parallel NW and NNW paleo-flow directions, (Fig. 5.8 c), and rift-orthogonal flows, i.e. E-W and NE trends. The latter were proved from the directions of inverted channels and paleo-rivers (see Fig. 5.11). Further to the north, west of Minia, tilted red conglomeratic and sandstone beds are exposed at fault contacts with Middle Eocene marls (Fig. 5.8 f). These rift-related clastics show brittle and ductile synsedimentary structures such as drag folds, fracture, and slumps as an emphasis on the syn-rift depositional conditions that we indicated earlier (see Fig. 6.6 f-i).

The Oligocene gravels in some locations west of Sohag city are capped by $25-30 \mathrm{~m}$ thick red cross-bedded sandstone and siltstone beds, which are equivalent to the widely-known Oligocene red beds of the central and southern parts of the Gulf of Suez rift (Fig. 5.8 d-e, see Fig. 4.6). The younger Miocene, Plio-Pleistocene and Quaternary clastics were successively deposited along the western and eastern grabens of the Nile Valley, and filling the main Eonile canyon and the ancestral delta of the paleo-rivers that flowed into the Western Desert (see Fig. 3.3). These clastics were sourced by paleo-rivers of prevailing westward and north-to-northwestward flowing directions, which dissected the uplifted Precambrian basement and Cretaceous rocks in the southern and eastern highlands of the Red Sea-Gulf of Suez hills as well as the Eocene cherty limestones of the central and northern shoulders of the RN.

Relatively thick Oligocene and Miocene clastics are exposed along the margins of the ancestral Moghra delta west of the Fayium depression and Assiut-Beni Suef district (Fig. 5.6). The outcrops are composed mainly of channel reddish sandstone and siltstone beds with some occurrences of palaeosols and tidal/estuarine facies. This in addition to poorly lithified sands and gravels that change in some exposures to cross-bedded hard sandstone and conglomerate beds of $\sim 20-25 \mathrm{~m}$ thickness that contains petrified wood fragments and roots. Further to the north in Gebel Qatrani, north of Fayium, the Oligocene sandstone red beds of Qatrani Formation are overlain by thick sheets of Oligo-Miocene ( $22.5 \mathrm{Ma}$, this study) vesicular and amygdaloidal basaltic flows (Fig. 5.9). Some quartzite occurs along NW and NNW-trending fractures and fault zones, which can be interpreted due to the mineralization of silica-rich fluids that erupted contemporaneously with the rift-related volcanism. 


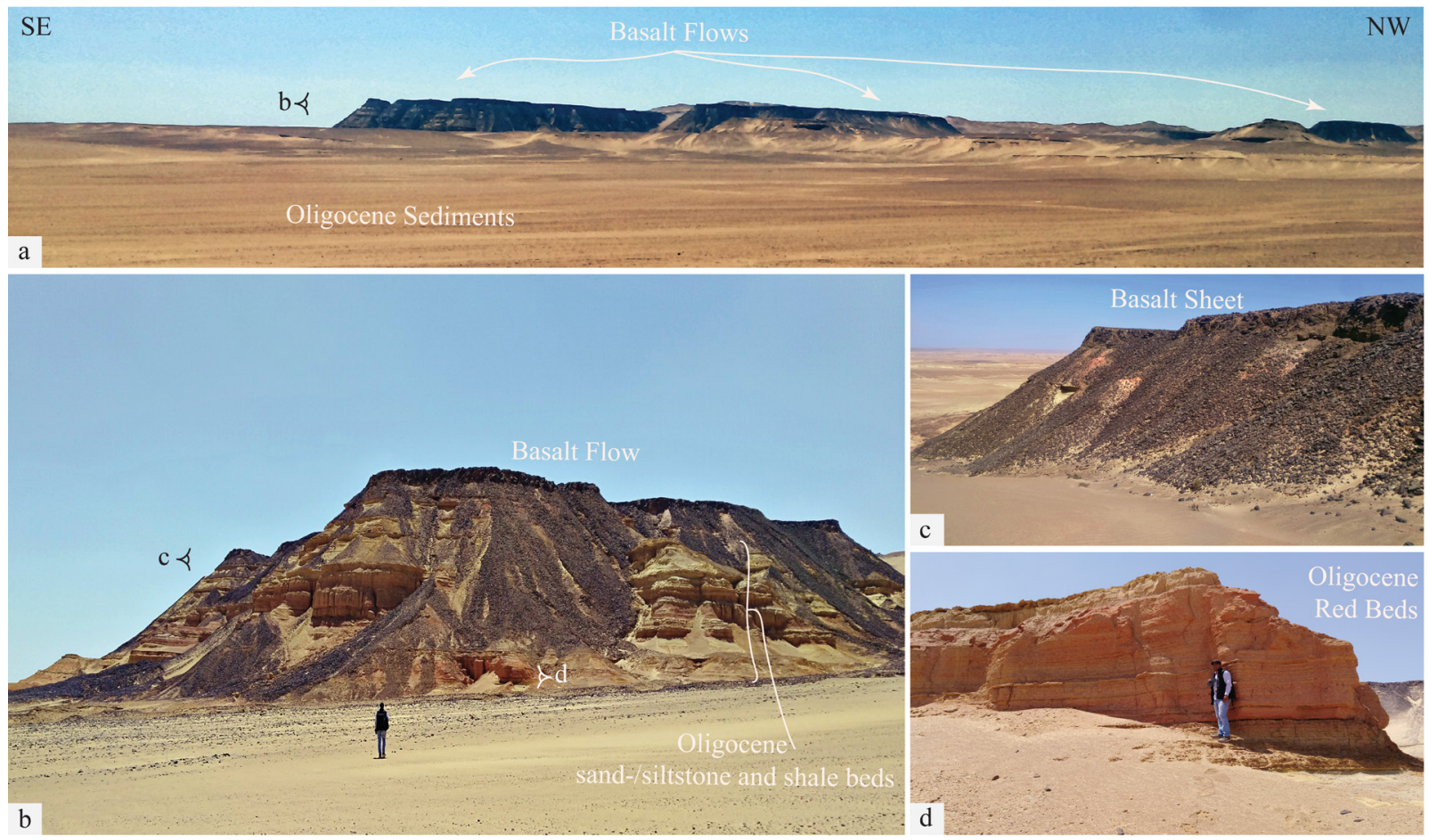

Fig. 5.9. The outcrop geology of Gebel Qatrani, northwestern Nile Rift System, west Fayium. a) Panoramic view of the basalt sheets overlying the Oligocene clastics of Qatrani Formation. b) Channel sandstone and siltstone beds with occurrences of palaeosols and tidal/estuarine facies and red beds (d). c) Rift-related basaltic flows unconformably overlying the earliest synrift fluviatile clastics of the Oligocene Qatrani Formation. The age of basalt in this locality according to K/Ar age-dating of the present work is $24 \mathrm{Ma}$; see Table 1, Sample (QT-3).

The structural architecture of the Nile Valley area resulted in a heterogeneous distribution of the Oligocene clastics along its shoulders. The structural high blocks, horsts and anticlinal ridges show absence or thin occurrences of the Oligocene gravels and sands, while intervening shallow grabens and troughs received relatively thicker accumulation fluviatile sediments particularly on the western shoulders of the central Eocene plateau of the river (Fig. 5.4 \& Fig. 5.5). Local riftorthogonal and oblique channels from the elevating rift shoulders along the Ancestral Nile, which are currently preserved as inverted topographies, would have filled the structural grabens and shallow troughs as well as the main canyon and delta of the river valley (Fig. 5.11). This is in addition to the regional flow trends and longitudinal pathways involved in the general northwestward gradient toward the Ancestral delta.

\subsection{Nile Basin Inverted Channels}

Inverted, also known as exhumed or raised, channel systems have been used by several studies to reconstruct the evolution history of various environmental, hydrologic, and climatic changes particularly during the Cenozoic. Exhumation of gravel-filled channels occurs due to their 
relatively higher resistance to erosion compared to the surrounding lithology, which results in the preservation of incised gravel-filled channels as ridges overlying older units of lower topography (Fig. 5.10). The analysis of high-resolution digital elevation and terrain models in conjunction with fieldwork and processing algorithms of satellite data revealed a network of kmscale exhumed gravel-filled channels within the eastern and western Eocene carbonate shoulders of the Nile Valley (Fig. 5.11). Although some outcrops are covered with a thick layer of dust where it is quite hard to characterize them, even on high-resolution Google-Earth imagery and DEMs, the results of applying spectral reflectance analysis, bands rationing, and principal components on satellite data were helpful to distinguish the Oligocene gravel and red sandstone bodies from the hosting Eocene carbonate rocks (see Chapter 2).

Inverted Channel: Dark-colored gravels on sinuous ridge

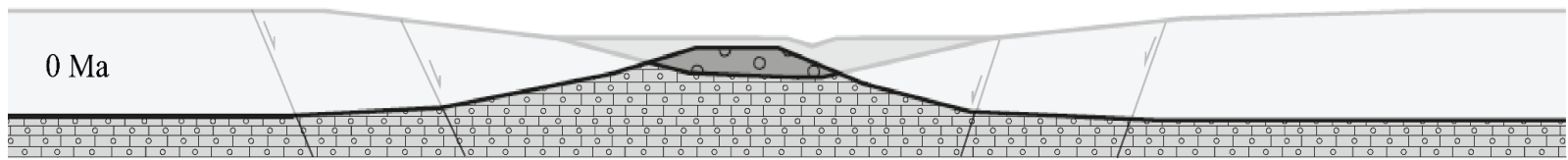

Oligocene River Channel

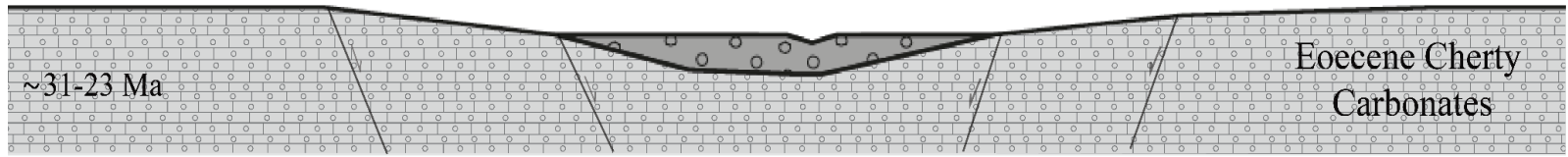

Fig. 5.10. Conceptual model for the development of the Oligocene inverted channels along the faulted-shoulders of the River Nile Rift System.

This study highlights the implication of present-day inverted topography to reconstruct the fluvial depositional system and possible flow direction(s) of the paleo-rivers that diagonally filled the main depression of the ancestral Moghra delta as well as some of the NW- and NNWoriented grabens and hangingwall fault blocks (Fig. 5.11). The gravels show some faunal assemblage of possible Lower to Middle Eocene origin. The Oligocene quartz arenite and gravels were possibly charged from the chert bands of the uplifted Drunka and Thebes Lower Eocene carbonates that made up the eastern and western shoulders of the Nile during the earliest phase of rifting in the Late Oligocene (Fig. 5.10). These rift shoulders were subjected to extensive faulting, severe erosion, and incisions in later times. 
Fig. 5.11. The inverted Oligocene gravel-filled channels of the River Nile Rift System. Locations are shown in the map (d). Most of the channels have a rift-orthogonal paleo flow direction i.e. NE trend. a) Digital elevation model showing one of the longest inverted channels in the western shoulder of the Nile Basin, the western area between Assiut and Minia, west of the Moghra basin. b) Inverted

Oligocene channel system flowing in the Beni Suef basin, northeast of the Nile, west Beni Suef. c) The inverted channels that filled early-formed syn-rift grabens of the Nile, west Sohag. d) Possible flow directions (black arrows) of the Oligocene paleo-rivers and channels of the Nile Rift.
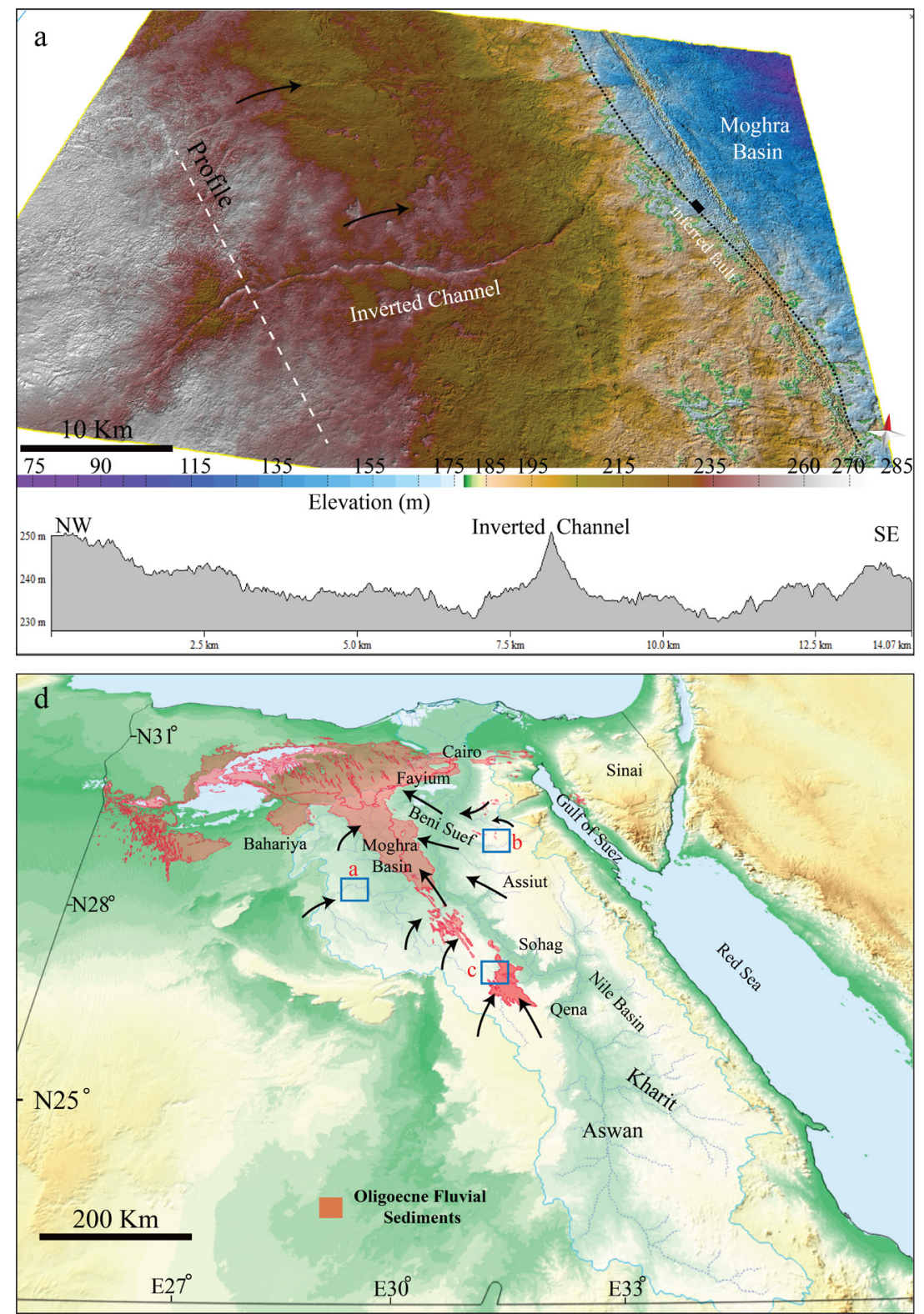
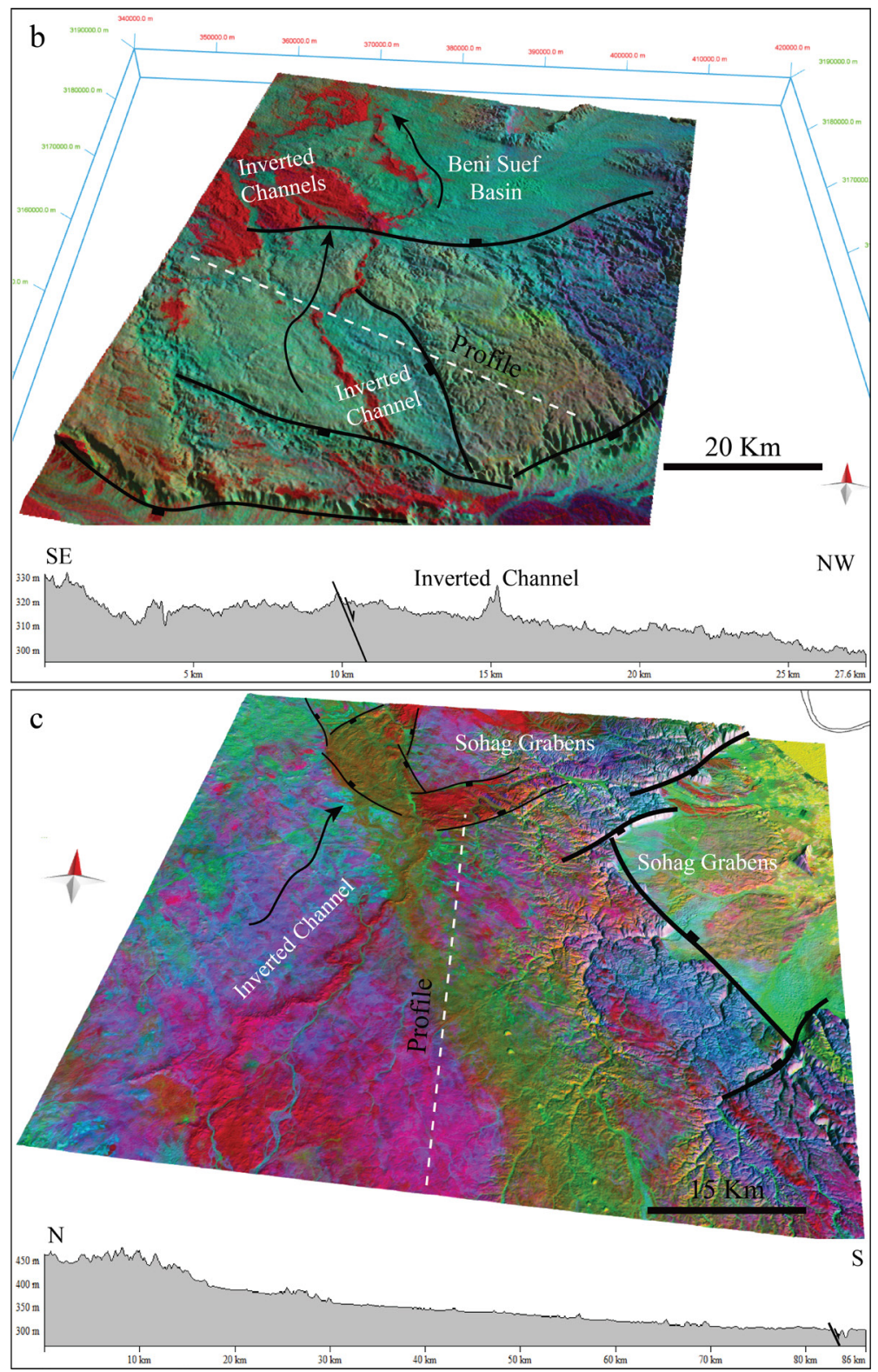


\subsection{Nile Grabens}

Numerous longitudinal narrow rift-related grabens and shallow troughs dissect the western and eastern Lower-Middle Eocene carbonates of the northern structural province of the Nile rift system (Fig. 5.17, Fig. 5.18 \& Fig. 5.19, see also Fig. 5.1 \& Fig. 5.4). These grabens extend for several tens of kilometres and are bounded by NW- to NNW-striking faults as well as cross elements of ENE and NE trends. Some of them hosted the rift alkali basaltic dikes and intrusions (Fig. 5.3). 3D seismic data of Bosworth et al. (2015b) showed that linear grabens underlying basalt dikes extend further northwest into the Western Desert and comprise circular depressions that formed as a result of collapsed walls associated with the magma evacuation. The western Nile grabens are filled with early syn-rift Oligocene gravels/sandstones that unconformably overlie older Eocene limestones, while others host Miocene, Plio-Pleistocene, and Quaternary coarse clastics and fluviatile sediments of the Nile Valley depositional systems. The ancestral rivers and deep canyons of the Nile Valley were incised along these grabens.

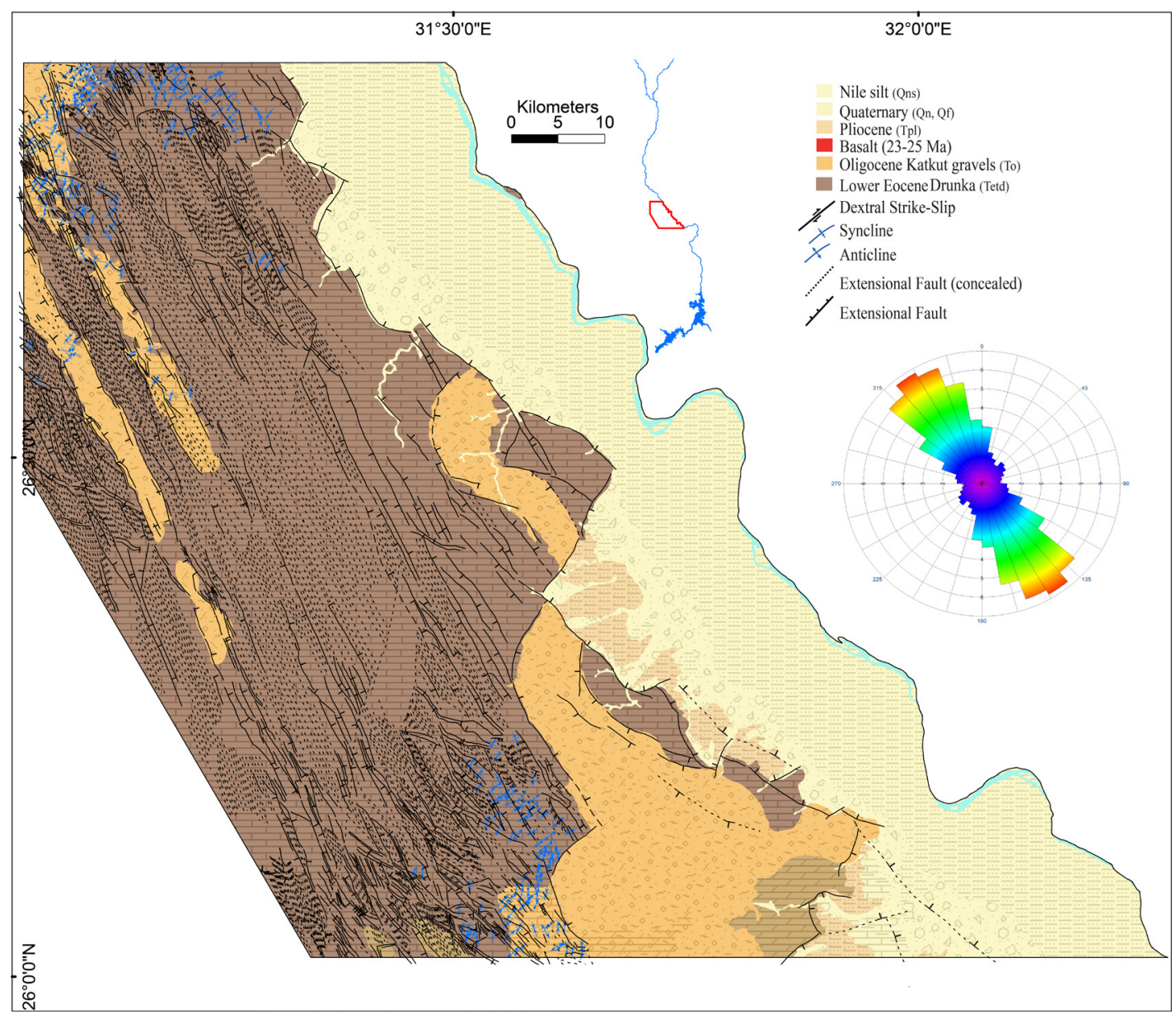

Fig. 5.12. The River Nile Rift Grabens, West of Sohag. Notice the similarity between the architecture and geometry of the syn-rift gravels-filled grabens and the course of the Pliocene to Quaternary Nile Valley. 


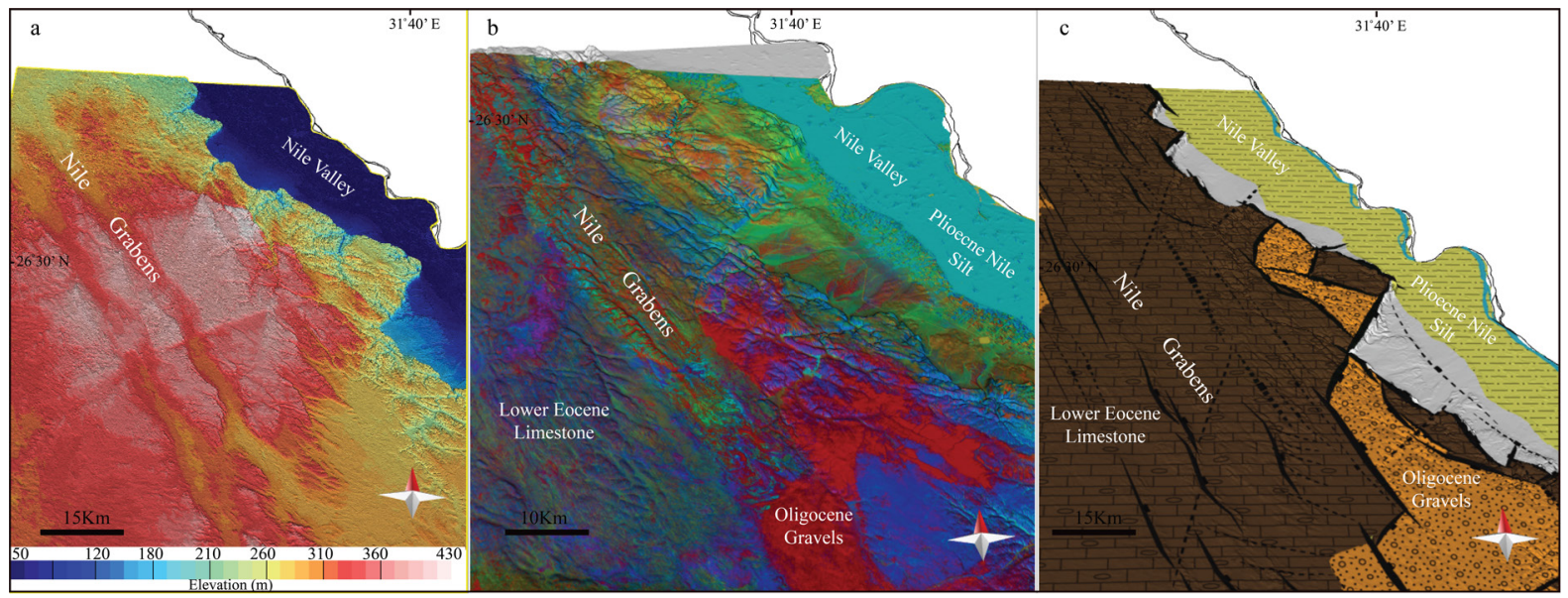

Fig. 5.13. (3D) views of the early-formed "juvenile" grabens that were filled with syn-rift Oligocene clastics. a) DEM surface of the longitudinal narrow grabens on the western shoulders of the Nile showing the interactions between both rift-parallel $(N W-\& N N W$-striking) and rift-orthogonal (E-W\&NE-striking) faults that shaped the grabens (c). b) The processed Sentinel2 image (PCs 5, 3, 2) used to discriminate the Oligocene gravels filling the rift grabens (see Chapter 2). c) Structural model for the Oligocene juvenile grabens along the western shoulders of the central Nile rift segment, west Sohag.

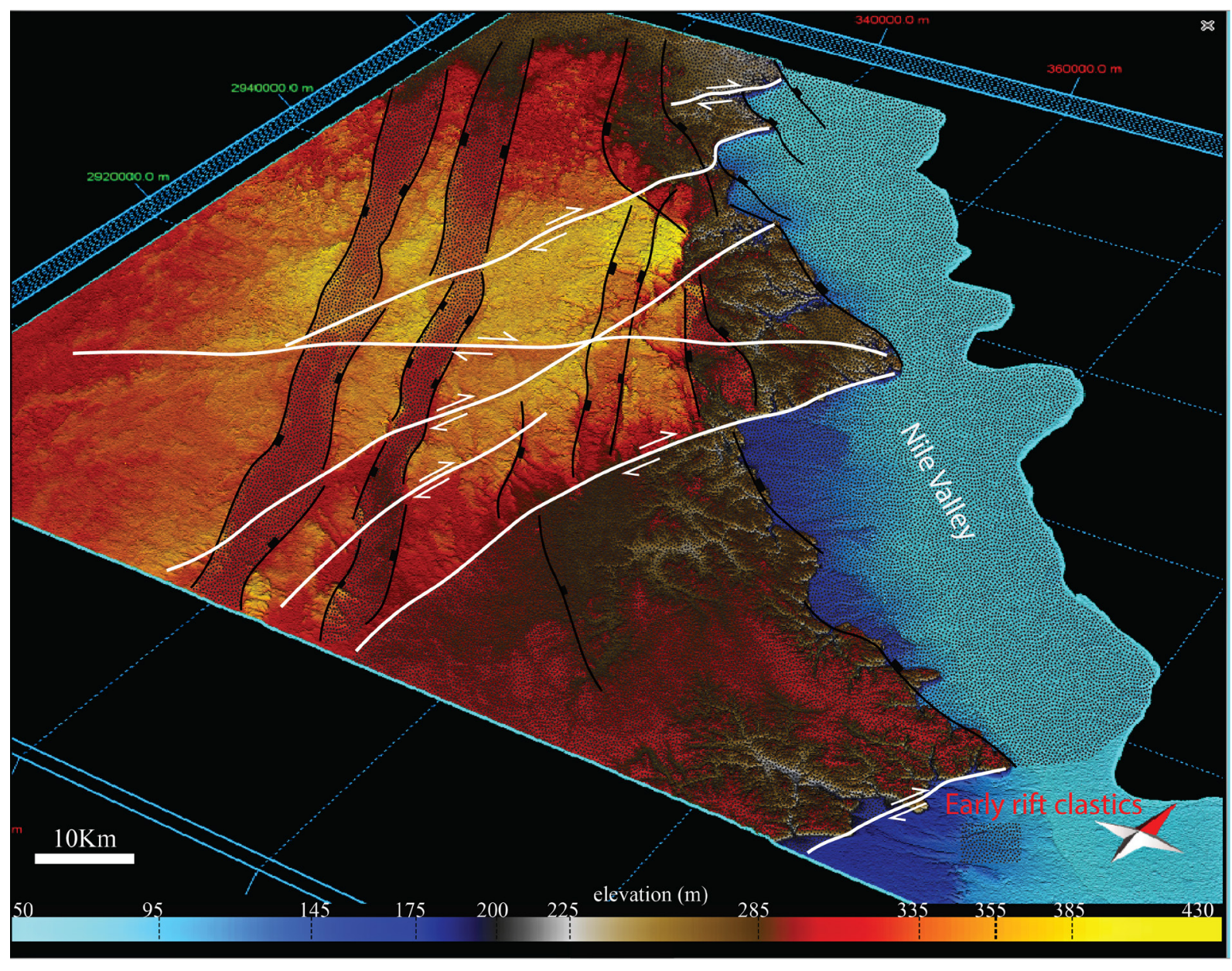

Fig. 5.14. Zig-zag linked fault pattern of the rift-parallel and rift-orthogonal (dextral strike-slip cross elements) that controlled the development of the western Nile grabens and early syn-rift fluvial sedimentation of the Oligocene clastics unconformably on the pre-rift Eocene strata. It shows the structural control of the early rift structures on the successive incisions of the ancestral Nile river(s) and channels. 


\subsection{Nile Rift Volcanics}

Basalt volcanic rocks in form of sills, dikes, and flows extend in several exposures in eastern and northern Egypt along the Red Sea-Gulf of Suez rift systems (see Fig. 2.7 a). These volcanics were dated and attributed to the magmatic activities that accompanied the early extensional rifting phase during the Late Oligocene-Early Miocene (Meneisy, 1990; Bosworth and McClay, 2001). Several outcrops of rift-related basaltic volcanics occur as well as along the western and eastern shoulders of the Nile Basin (Fig. 5.12, Fig. 5.13, Fig. 5.14 \& Fig. 5.15). The present work suggests that the volcanism has been erupted as a result of the onset of a rifting phase along the Nile Valley at $\sim 25-23$ Ma that was aborted at a very early stage (Table 1). This was coincident and genetically related to the initiation of rifting in the Red Sea and Gulf of Suez basins. I have studied 26 samples distributed in 10 localities along the eastern and western shoulders of the central and northern Nile rift system (Fig. 5.16).

The Nile volcanics occur mainly as monogenetic fissure eruptions and shallow-intrusion bodies. The basalt fissure eruptions and dikes to the north of the Nile, northwest of Beni Suef, are arranged along extensional faults and fractures in a characteristic en echelon pattern with dominant NW trends subparallel to the Gulf of Suez NNW-oriented rift (Fig. 5.12). These NWtrending en echelon basalt dikes and faults might be connected to deep-seated faults. The NW trends change further north into two NE-oriented belts at Gebel Qatrani north of Fayium depression, and west Cairo (Fig. 5.16). Some basalts have been erupted at the Eocene and Upper cretaceous cores of NW-oriented forced anticlinal folds. Examples are the anticlines of Gebel Gebeil and Kolet El-Fartilla west and east of Assiut (Fig. 5.15). 

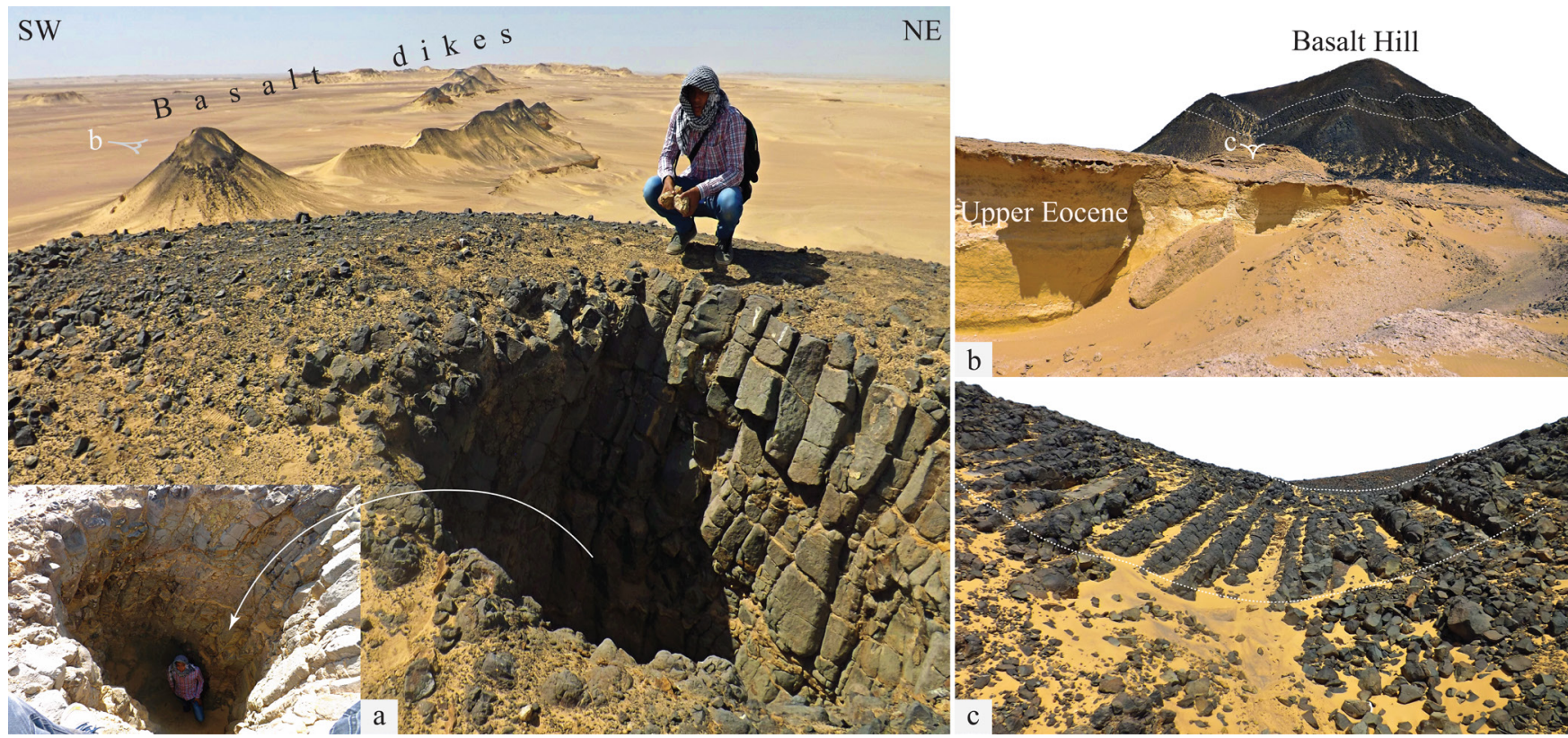

Fig. 5.15. Basalt dike occurrences, northwest Beni Suef, west Nile. a) En echelon pattern of NW-oriented basalt dikes and hills. b) Collapsed basalt cinder cone overlying oyster beds of the Upper Eocene Qasr El-Sagha Formation. c) Columnar joints of the sag-walls of the basalt hill. The age of basalt in this locality according to K/Ar age-dating of the present work is 21 Ma, see Table 1; Sample (QZ-1).
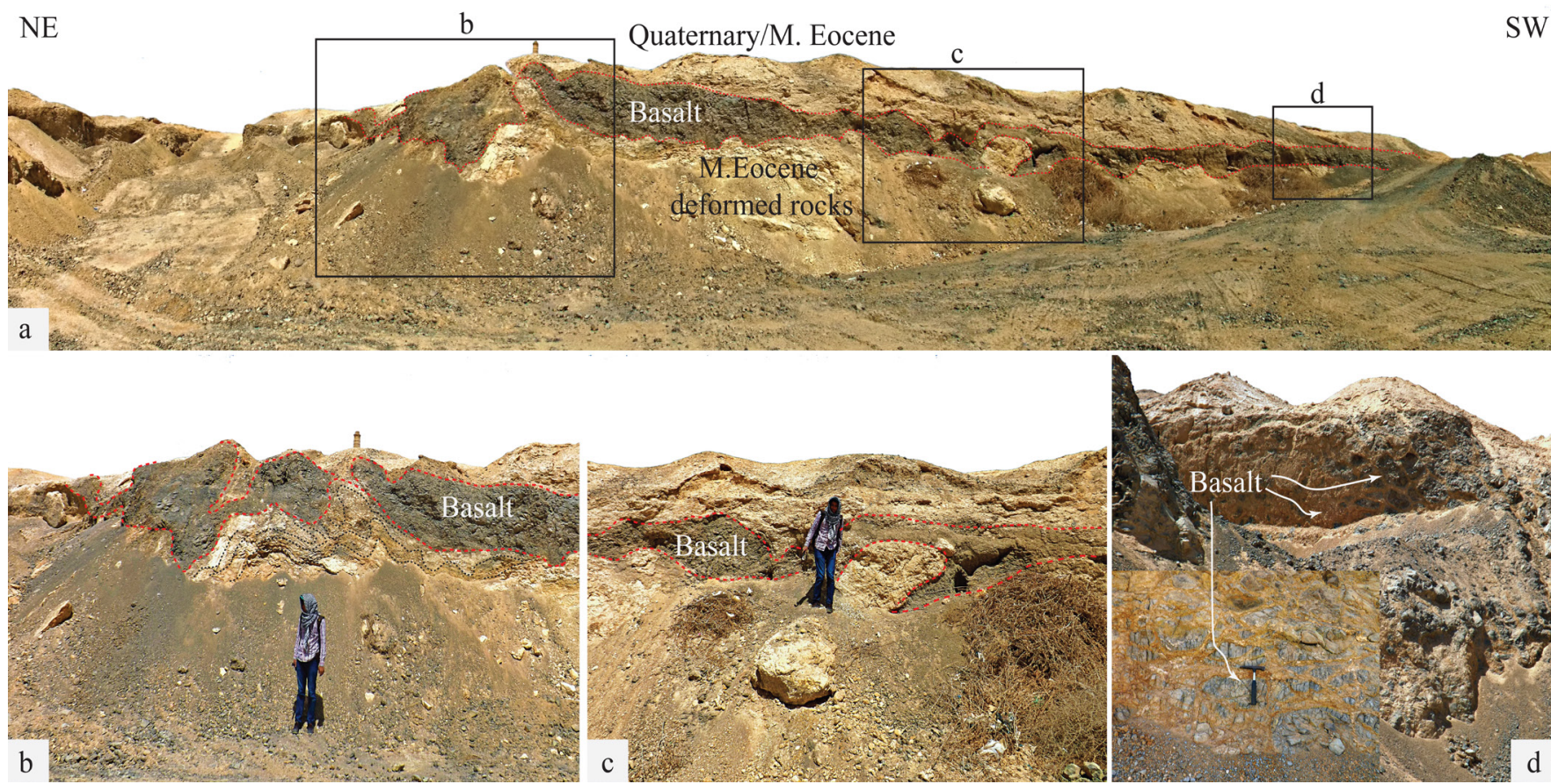

Fig. 5.16. Basalt sill occurrences, Gebel Samalut, east Minia, east Nile. a) Panoramic view of basalt sill intruded the pre-rift Middle Eocene carbonates of Samalut Formation. The limestones and marls of the Samalut Formation show extensive ductile deformation, flow and piercement structures as a result of the syn-rift basalt intrusions $(b \& c)$. d) Basalt inclusions in the Middle Eocene carbonates. The age of basalt in this locality according to the K/Ar age-dating of the present work is $20.5 \mathrm{Ma}$; see Table 1, Sample (SMS-2). 
The petrographic and geochemical investigations show that rock samples from multiple magmatic events display a large variety in texture and in modal mineral compositions. They range from olivine dolerites and olivine-bearing basalts to vitrophyric, texturally heterogeneous basalts and crystal lithic tuffs. The transitional tholeiitic basalts display low compatible element concentrations and enrichment of the whole spectrum of the incompatible elements. Major, trace and Rare Earth Element data suggest that the melts formed by 5\% melting of mantle peridotite at the spinel-garnet transition zone $(80-90 \mathrm{~km} \mathrm{depth})$, in the presence of $2-4 \%$ residual garnet.

During the melt ascent, the fractionating phases were olivine, clinopyroxene and, to a lesser extent, plagioclase. These Nile basalts are correlated with some of the basalts that were studied by Bosworth et al. (2015b) who reported that ${ }^{40} \mathrm{Ar} /{ }^{39} \mathrm{Ar}$ dating of samples in northern Egypt as well as at the Gulf of Suez basin indicates that widespread and voluminous volcanism occurred over a short time interval of less than $2 \mathrm{Ma}$ at the Oligocene-Miocene boundary ( 23 Ma). The present study concludes that the K/Ar dating of fourteen samples distributed along the western and eastern flanks of the central and northern Nile show variable phases of eruptions that range between Oligocene and Early Miocene with an average age of $25-23 \mathrm{Ma}$ (Table 1, see Fig. 5.16).

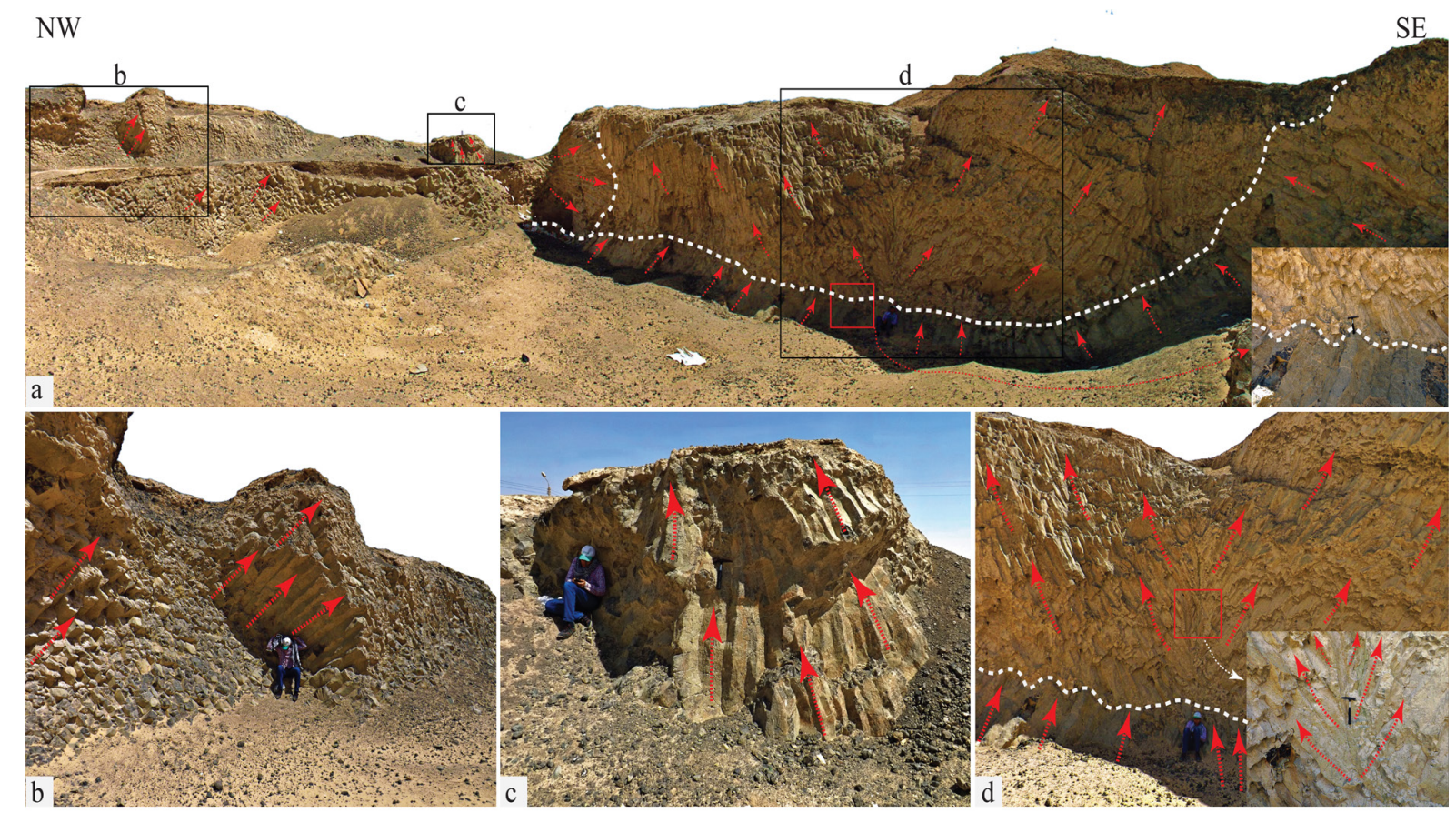

Fig. 5.17. Basalt columnar joints of variable geometries, east Minia, east Nile Valley (a). The multiple geometries of the columnar joints as well as the different structural settings and lithological characteristics of the basalt outcrops might imply successive "short-lived "syn-rifting phases of volcanism $(b \& c)$. Basalt fissure eruption with a characteristic plumose structure (d). The age of basalt in this locality according to K/Ar age-dating of the present work differs between $\sim 29.5,31.6$ and 33.2 Ma. This indicates multiple eruptions of the Nile Rift-related basaltic volcanism during the Late Oligocene; see Table 1; Samples (SMN, SMT\& SMB), respectively. 


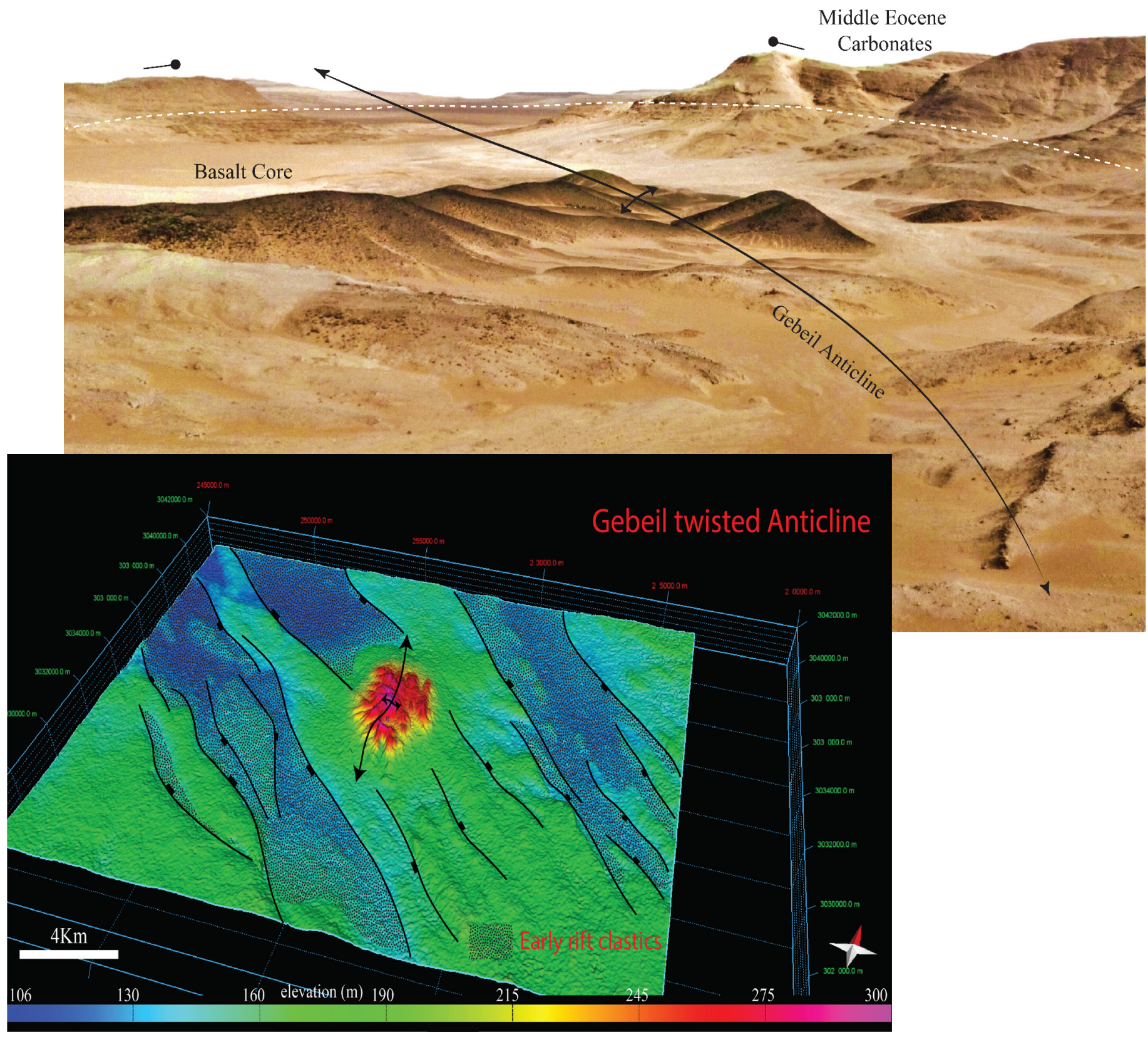

Fig. 5.18. Forced folding of Gebel Gebeil Anticline. NW-oriented anticline within the Lower Eocene carbonates of Thebes and Drunka formations of G. Gebeil, west Assiut (the upper field photo). The folds were formed as a result of a local uplift accompanied the syn-rift basaltic intrusions (core of the anticline), however, the area was dominated by extensional deformation that developed numerous fault-bounded grabens that hosted the early syn-rift clastics (the lower $3 D$ view). The age of basalt in this locality according to K/Ar age-dating of the present work is 28 Ma, see Table 1; Sample (GG-1). 
Fig. 5.19. Distribution of the Late Oligocene-Early Miocene Nile and Gulf of Suez rift-related basalts (red). The small multi-colored dots show the locations of 26 basalt samples collected along the shoulders of the Nile Rift System. The green asterisks (*) represent the localities of 14 samples that were chosen for whole-rock $K / A r$ age-dating (seeTable 1).

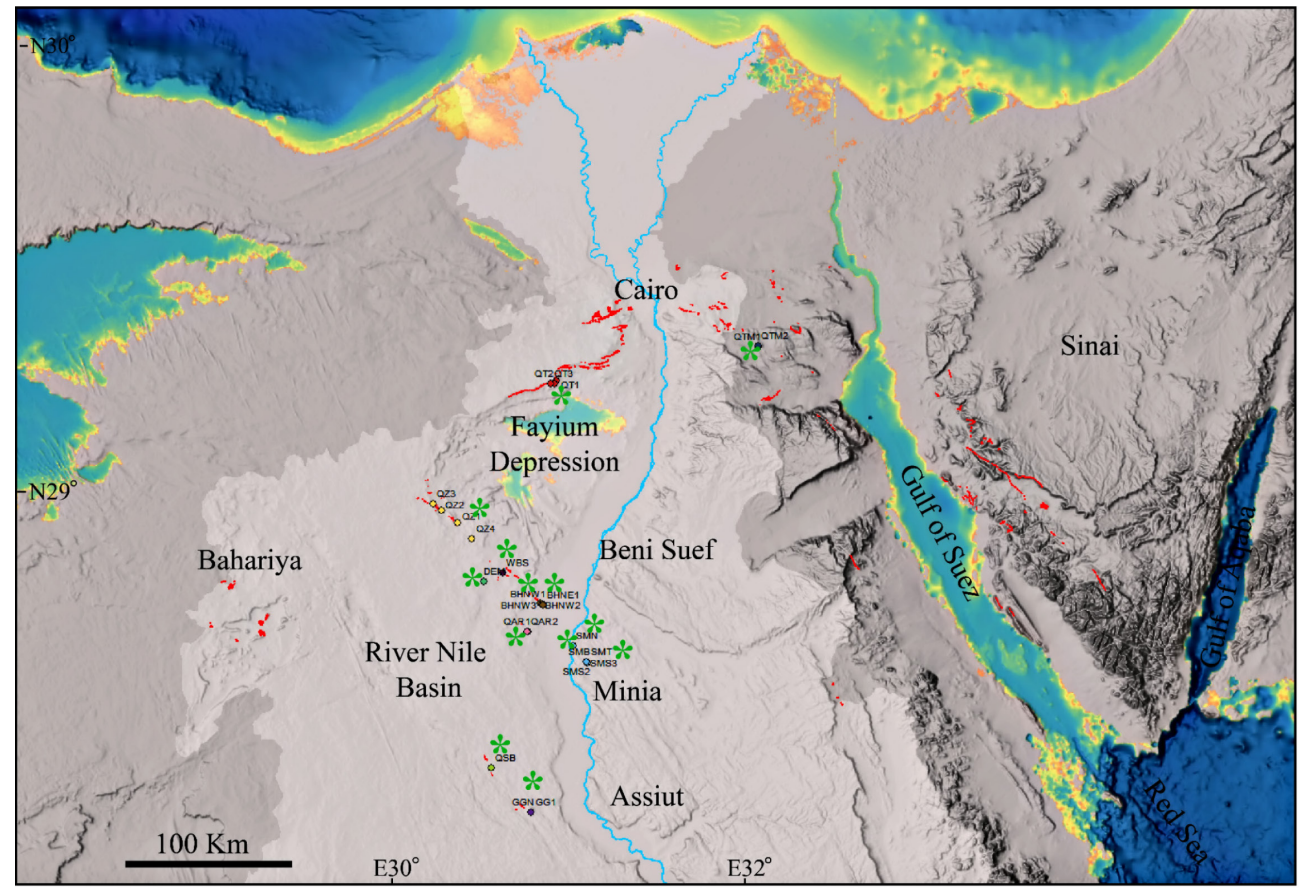

Table 1. The Whole-rock K/Ar age data of 14 basalt samples in the study area (River Nile rift-related volcanics; average age $25-23$ $\mathrm{Ma}$ ).

\begin{tabular}{|c|c|c|c|c|c|c|c|}
\hline $\begin{array}{l}\text { Ar-Isotopic } \\
\text { Abundance }\end{array}$ & \multicolumn{2}{|c|}{ Spike-Isotopic Comp. } & \multicolumn{2}{|c|}{ Decay Constants [1/a]: } & \multicolumn{3}{|c|}{ Potassium } \\
\hline \multirow{3}{*}{$\begin{array}{l}{ }^{40} \mathrm{Ar}: 99.6000 \% \\
{ }^{38} \mathrm{Ar}: 0.0630 \% \\
{ }^{36} \mathrm{Ar}: 0.3370 \%\end{array}$} & \multirow{3}{*}{\multicolumn{2}{|c|}{$\begin{array}{l}{ }^{40} \mathrm{Ar}: 0.0099980 \% \\
{ }^{38} \mathrm{Ar}: 99.9890000 \% \\
{ }^{36} \mathrm{Ar}: 0.0009998 \%\end{array}$}} & \multirow{2}{*}{\multicolumn{2}{|c|}{$\begin{array}{l}\lambda \varepsilon: 5.810 \mathrm{E}-11 \\
\lambda \beta: 4.962 \mathrm{E}-10\end{array}$}} & \multicolumn{3}{|c|}{$\begin{array}{l}{ }^{40} \mathrm{~K}: 0.011670 \% \\
\mathrm{~K}_{2} \mathrm{O} / \mathrm{K}: 0.8302 \\
\end{array}$} \\
\hline & & & & & \multirow{4}{*}{\multicolumn{3}{|c|}{$\begin{array}{l}\text { Atomic Weight [g/mol]: } \\
\text { tot Ar: } 39.9477 \\
{ }^{40} \text { Ar: } 39.9624 \\
\text { tot K: } 39.1027\end{array}$}} \\
\hline & & & $\lambda$ tot: $5.543 \mathrm{E}$ & & & & \\
\hline $\begin{array}{l}\text { Standard Temp } \\
0^{\circ} \mathrm{C} ; 760 \mathrm{~mm} \mathrm{Hg}\end{array}$ & erature Press & re (STP) & $\begin{array}{l}\text { Molar Volun } \\
22413.8 \\
\end{array}$ & & & & \\
\hline \multicolumn{5}{|c|}{ Normal Atmosphere (DIN 1343) 273.15 K; 1013.25 mbar } & & & \\
\hline Sample & Spike [No.] & $\mathrm{K}_{2} \mathrm{O}[\mathrm{Wt} . \%]$ & $\begin{array}{c}{ }^{40} \mathrm{Ar} *[\mathrm{nl} / \mathrm{g}] \\
\text { STP }\end{array}$ & $\begin{array}{c}{ }^{40} \mathrm{Ar} * \\
{[\%]}\end{array}$ & $\begin{array}{l}\text { Age } \\
\text { [Ma] }\end{array}$ & $\begin{array}{c}\text { 2s-Error } \\
{[\mathrm{Ma}]}\end{array}$ & $\begin{array}{c}\text { 2s-Error } \\
{[\%]}\end{array}$ \\
\hline BHN-E-1 & 6175 & 0.496 & 0.35 & 15.10 & 21.6 & 1.5 & 6.9 \\
\hline BHN-W-1 & 6119 & 0.456 & 0.32 & 28.84 & 22.0 & 0.8 & 3.6 \\
\hline DEM & 6122 & 0.631 & 0.45 & 15.91 & 22.0 & 1.4 & 6.3 \\
\hline GG-1 & 6124 & 1.325 & 1.21 & 24.14 & 28.0 & 1.2 & 4.3 \\
\hline QAR-1 & 6174 & 0.538 & 0.56 & 19.11 & 31.7 & 1.8 & 5.7 \\
\hline QSB & 6123 & 1.332 & 1.11 & 17.51 & 25.6 & 1.5 & 6.0 \\
\hline QT-3 & 6177 & 0.910 & 0.72 & 22.09 & 24.2 & 1.1 & 4.5 \\
\hline QTM-1 & 6176 & 0.369 & 0.35 & 15.18 & 29.2 & 2.0 & 6.8 \\
\hline QZ-1 & 6126 & 0.523 & 0.35 & 24.94 & 20.7 & 0.9 & 4.3 \\
\hline SMB & 6168 & 0.395 & 0.43 & 21.47 & 33.2 & 1.7 & 5.1 \\
\hline SMN & 6170 & 0.441 & 0.42 & 27.93 & 29.5 & 1.1 & 3.7 \\
\hline SMS-2 & 6125 & 0.259 & 0.17 & 16.88 & 20.4 & 1.2 & 5.9 \\
\hline SMT & 6169 & 0.432 & 0.44 & 39.10 & 31.6 & 0.8 & 2.5 \\
\hline WBS & 6185 & 0.529 & 0.38 & 7.79 & 22.1 & 1.2 & 5.4 \\
\hline
\end{tabular}




\subsection{Ancestral "Moghra Delta" Structural Trough}

The area of the RN basin comprises five main geomorphic units; the Eastern basement highs of the Red Sea-Gulf of Suez hills, the southern Cretaceous basins and troughs, the eastern and western Lower-Middle Eocene Limestone plateaux, the central Nile Valley/Canyon and the northwestern depression (graben) of the ancestral "Moghra" delta. The last two units received the fluvial-dominated sediments and rift-related clastics of the Nile Rift System (see Fig. 1.3, Fig. 1.5, Fig. 5.6 \& Fig. 5.8). These sediments postdate and unconformably overlain the Eocene strata of the rift grabens and troughs. The Moghra delta trough represents a low-stand topographic area that has accommodated most of the alluvial deposits of the ancestral Late Oligocene-Early to Middle Miocene paleo-rivers and drainage systems of the Nile. It also receives the waterfalls and water-flashes through crossing wadi courses from the surrounding elevated plateaux. This study suggests that the Moghra is a structurally-controlled delta that was developed by subsidence and flows rolled by extensional tectonics, rather than a depression that was originated only by erosion and incisions of the paleo-rivers (see Fig. 2.3, Fig. 3.2 \& Fig. 5.6).

The Moghra trough represents a "juvenile" half-graben basin that is bounded from the south by the E-W oriented faults of Wadi Assiuty shear zone and from the west by extensional faults of NW trends (Fig. 3.2). This might indicate short and slow tectonic subsidence during the Late Oligocene-Early Miocene earliest phase of the Nile rifting. The Moghra trough is gradually bounded from the north by a NE-oriented uplifted zone that coincides with the volcanic occurrences of the NE-trending belt of Gebel Qatrani and rooted by the inverted Syrian Arc Cretaceous ridge of the Kattaniya High (see Fig. 1.3, Fig. 2.11 \& Fig. 2.13). This structural high was originated as a result of basin inversion during the Late Cretaceous convergence and Syrian Arc wrench tectonics. We think the Late Oligocene-Early Miocene phase of uplifting across this area might be attributed to massive volcanic intrusions that can be observed in several outcrops, and were encountered and interpreted in boreholes, and seismic profiles. 


\section{Chapter 6 River Nile Rift Segmentation and Termination}




\section{Introduction}

By the present work three main Late Paleogene-Early Neogene NW to NNW rift segments (described here as southern, central and northern) and are separated by oblique E-ENE-trending transfer zones are characterized for the first time (Fig. 6.1). These rift segments are exposed on the eastern and western flanks of the river, and were rejuvenated along NW-trending basement shears and intracontinental basins, which developed formerly during the Mesozoic rifting (see Chapter 4). The central and northern segments are geometrically well-defined and semiparallel to the Red Sea-Gulf of Suez rift system, while the southern segment has an oblique complex-pattern, due to interference with E-W, NE- and N-S striking pre-existing structures (Fig. 6.1). The locations of both rift segments and transfer zones were strongly influenced by the inherited Precambrian basement shear zones and topographic highs as well as older Mesozoic rift basins. The ancestral and present-day drainage systems of the River Nile were developed along the three main intracontinental rift segments. They were in turn rejuvenated along the Mesozoic rift basins and their bounding faults, which are distributed along the eastern and western extents of the Nile course, and formed originally during the Early Cretaceous rifting phases in southern and central and Egypt (from south to north; Kharit, Nuqra, KomOmbo, Assiut and Beni Suef basins (Fig. 6.1, see also Fig. 4.3, Fig. 4.7 \& Fig. 4.8).

The reactivation of NW-trending basement shear zones and pre-existing structures controlled the geometry of the southern rift segment along Kharit, Nuqra, and KomOmbo basins in addition to Beni Suef basin in the north. While others of NNW trends influenced the orientation of the central and northern rift segments including the Cretaceous Assiut basin (see Fig. 4.4 \& Fig. 4.8). Highly oblique E-W to ENE dextral shear zones along Wadi Assiuty and Qena dome (Great Qena bend) represent two main transfer zones; across them, the rift segments and faults show flipping of their locations and prevailing polarities (Fig. 6.1). Further to the north, ENEto NE-oriented uplift, folds and dextral shears, as well as prominent thickening of the Mesozoic sediments in the northern basins terminated the northward propagation of the Late Paleogene Nile rift (see Fig. 1.3 \& Fig. 2.13). Most of these features were nucleated during the Mesozoic extensional phases and the succeeding basin inversion, Syrian Arc tectonics and the Late Cenozoic rifting. 

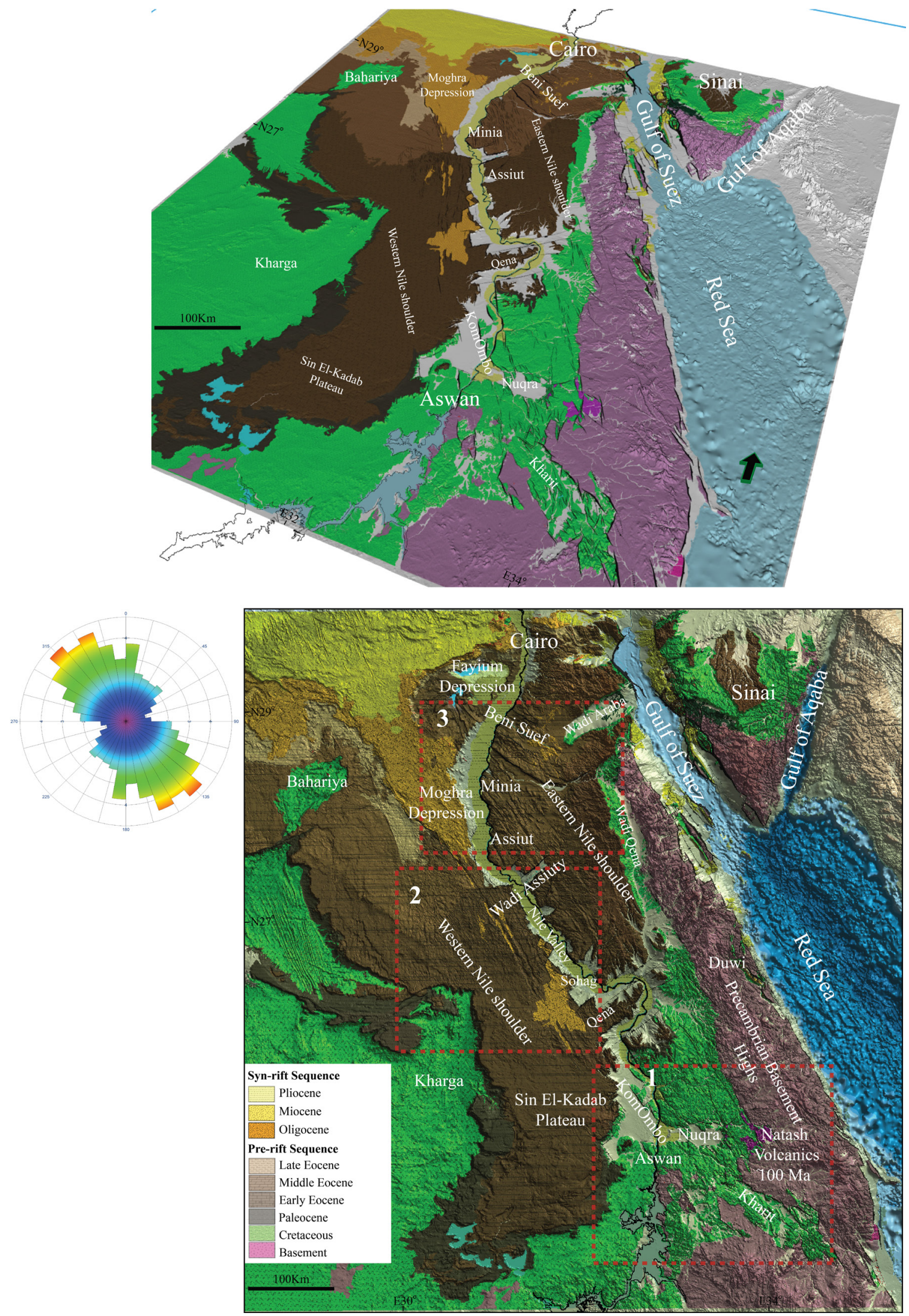

Fig. 6.1. General structural model of the proposed River Nile Rift System in the area between Aswan-Kharit and Cairo. The boundaries of the three main rift segments are outlined by red-dotted squares in the lower map and numbered as 1, 2 and 3 (southern, central and northern, respectively). The inset rose diagram shows the dominant trends of the rift bounding faults and cross elements along the Nile Valley. 


\subsection{Southern Rift Segment}

The southern Late Paleogene Nile rift segment that is described in this study comprises three NW-oriented rift basins that were formed in the Early Cretaceous; from South to North: Kharit, Nuqra, and KomOmbo (Fig. 6.2). These basins were tested by petroleum exploration where the geometry of them was interpreted based on gravity, magnetic, seismic and borehole datasets as well as outcrop geology (see Chapter 2 and Chapter 4). This is in addition to Wadi El-Quffa basin southwest of Kharit basin, which has not been tested yet (Fig. 6.2). The southern rift segment hosts the ancestral and present-day Nile Valley and its paleo and recent drainage systems (Fig. 6.3). This segment extends between the southern latitudes of Lake Nasser and the "Great Qena bend" to the north, and bounded from the east by the Precambrian basement outcrops of the Red Sea Hills, and shouldered on the west by cliffy exposures of the Lower Eocene carbonates, Paleocene Esna shales and Cretaceous rocks of the uplifted Sin El-Kadab Plateau.

The main trough of the southern segment is filled with Upper Cretaceous clastics and fluvial sediments that are overlain in some localities by the Nile's Neogene deposits particularly along the incisions and canyons of paleo-rivers in the Nuqra and KomOmbo troughs. Both the eastern and western shoulders of Kharit graben are made up of Precambrian basement rocks, while the Nuqra and KomOmbo grabens are bounded on the east by basement and Cretaceous sediments and on the west mainly by Lower Eocene Carbonates (Fig. 6.2). The spatial distribution of the faulted stratigraphic units might indicate a northward decrease of extension associated with the reduction of the amounts of vertical displacements of the rift-boundary faults during successive rifting phases.

The Kharit, KomOmbo, and Nuqra troughs represent half-graben basins of asymmetric rift system, which were filled by syn-rift Lower-Upper Cretaceous lacustrine, fluvial and shallow to marginal marine sediments that were rotated dominantly toward the northeastern rift-border faults (see Fig. 4.3). These basins are delineated on their northeastern boundaries with the main rift-border faults, which have SW-dipping planes, while the southern margins are bounded by antithetic faults with relatively smaller amounts of vertical displacements as well as less elevated and tilted shoulders (Fig. 6.2). 

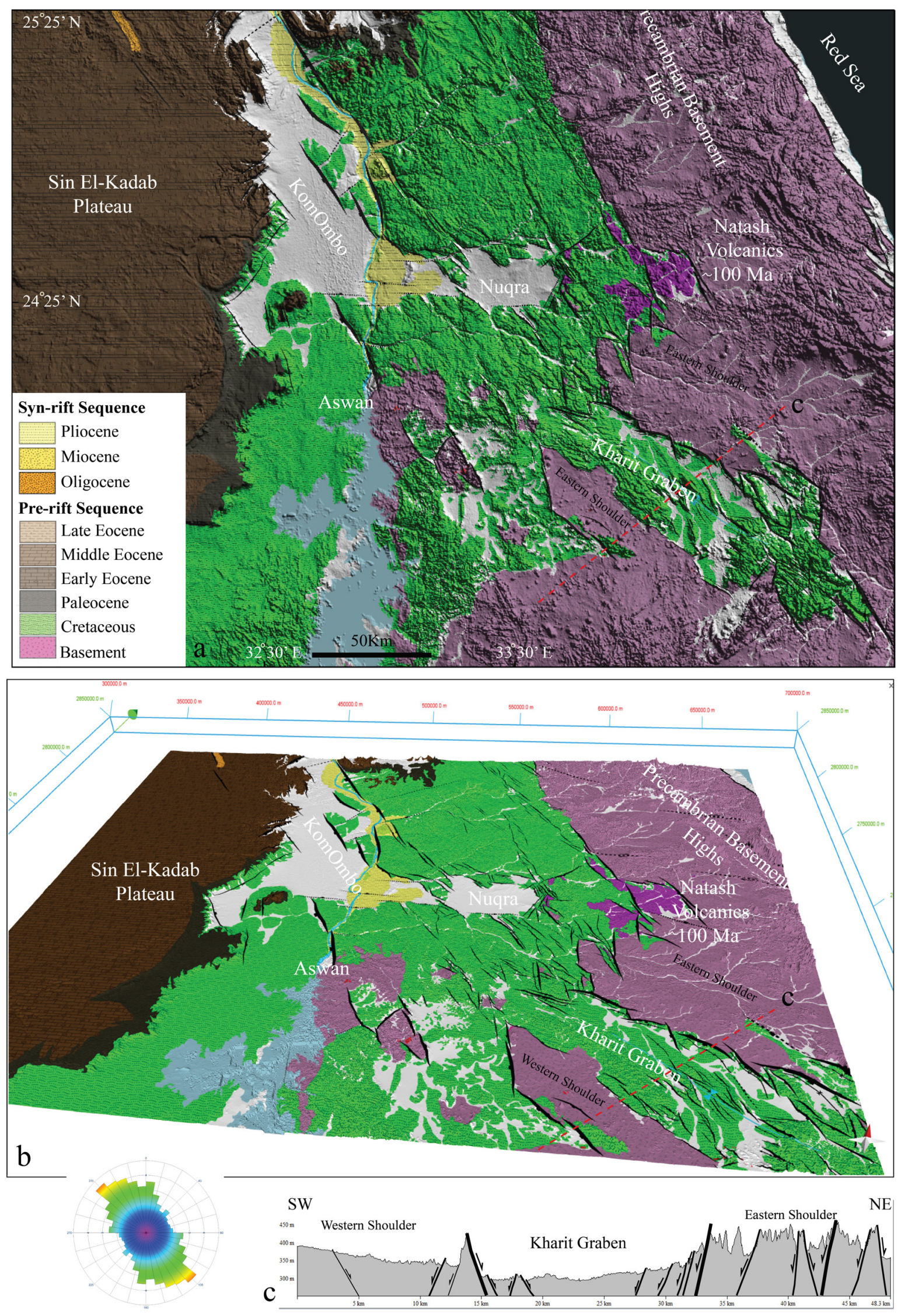

Fig. 6.2. Structural model of the Southern Nile Rift Segment. This includes the three main Early Cretaceous rift basins of the southern Nile Valley, Kharit, Nuqra and KomOmbo. The eastern shoulders of the Nuqra graben (rely area) host the Cretaceous syn-rift Natash volcanics ( 100 Ma). The inset rose diagram shows the dominant trends of the rift structures. 
The main troughs of the half-grabens are populated by NW-striking shorter fault segments of prevailing SW-dipping planes similar to those of the northeastern master faults. The surface stratigraphic separations and subsurface data show that the total vertical displacement along the rift-border faults that bound the northeastern up-thrown blocks of the southern Kharit basin is $\sim 2500 \mathrm{~m}$, while the southwestern is $\sim 2300 \mathrm{~m}$.

The eastern, northern and southern margins of the central Nuqra graben are characterized by interference of abundant NW, E-W and NE faults (Fig. 6.2). The E-W regional geometry of this trough in addition to the abundance of rift-orthogonal, rift-oblique, and antithetic fault segments indicate that it represents a relay area or transfer zone, which connects the NWoriented Kharit and KomOmbo basins (see Fig. 2.8c). This area represents a structural graben that is bounded from north and south by coalescing fault segments of NW and E-W trends, with fewer occurrences of NE-striking faults. The Nuqra trough hosts massive occurrences of the Early Cretaceous Natash volcanics ( 104 Ma; Meneisy, 1990) on its eastern margins, while the western and southern shoulders of Kharit basin were intruded by Tertiary volcanics (Fig. 6.2). The rift boundary faults of Kharit basin form an asymmetrical half-graben where the Upper Cretaceous sediments that are exposed in the main trough show a regional $15-20^{\circ}$ tilting toward the northeastern master fault segments. Extensional faults-related syncline folds of NW-SE axial traces were formed in the Cretaceous sediments of the hangingwalls of the northeastern rift boundary faults. Precambrian basement rocks are exposed along both the southeastern and western shoulders of the NW rift boundary master faults, while further to the north Cretaceous rocks form both the hanging- and footwalls of the fault segments. The frequency of faults increases further north at the expense of their vertical displacements with a hybrid fault area of different orientations.

What we described above indicates the northward decrease of extension as well as the gradual termination of the rift propagation in the southern segment. The borehole and seismic data show that the Precambrian basement rocks in Kharit basin were down-faulted to a depth of 2400-2700 m, while the deeper Nuqra basin accommodated $\sim 3350$ thick syn-rift Cretaceous sediments overlying unconformably basement rocks (Dolson et al., 2001; Mostafa et al., 2016). These faults are crossed by E-W striking faults south of Nuqra graben. The latter faults extend further to the west and bound the main trough of the southern rift segment south of Aswan 
governorate. Further to the northwest, west of the Nile, The KomOmbo half-graben is bounded form the East by a rift-border fault with less amount of vertical throws compared to Kharit and Nuqra, where Upper Cretaceous form its eastern shoulders in the south and change into Eocene rocks to the north, While Lower Eocene rocks are exposed on both eastern and western footwalls of the bounding faults (Fig. 6.2 \& Fig. 6.3, see also Fig. 4.3). The main trough of the KomOmbo basin is relatively shallower than the Nuqra and Kharit basins. It hosts unexposed syn-rift Cretaceous strata of $\sim 1500 \mathrm{~m}$ thickness. These are generally tilted and rotated toward the northeastern rift-bounding faults with a distinct prominent thickening. The depth to the Precambrian basement rocks decreases in KomOmbo basin with a maximum value of $\sim 1500$ $\mathrm{m}$ in the deepest trough along the main bounding faults, and decreases gradually up-dip to the southwest and measures $\sim 500 \mathrm{~m}$ (Nagati, 1986; Mostafa et al., 2016). The syn-rift Cretaceous sediments of KomOmbo basin are overlain unconformably by the Neogene fluvial clastics of the ancestral incisions of the RN (Fig. 6.3).

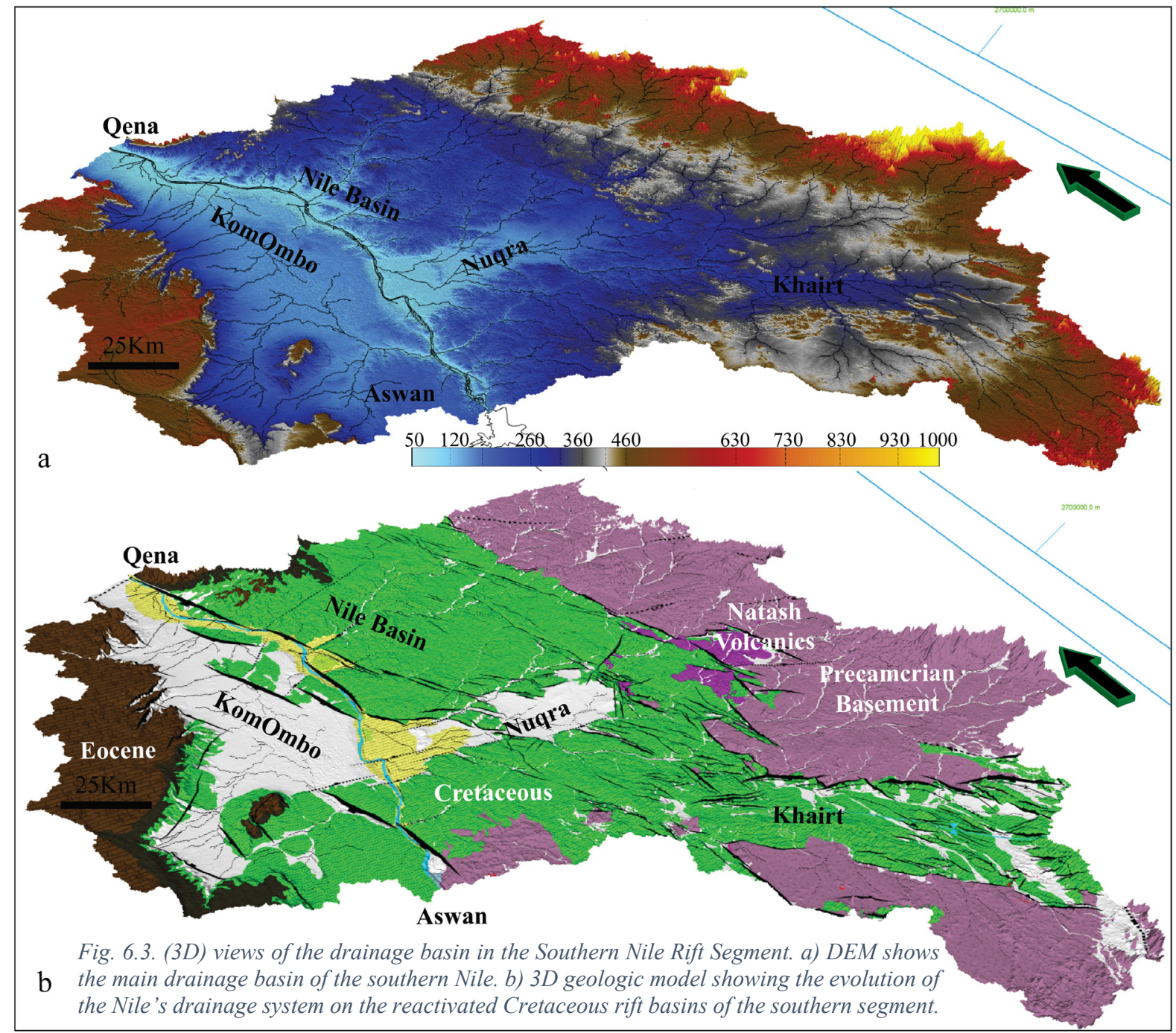




\subsection{Central Rift Segment}

The central Nile rift segment extends along the western and eastern stretches of Qena, Sohag and Assiut governorates. It is terminated at the south and north by the rift-orthogonal and riftoblique ENE- to NE-oriented transfer and shear zones of the major Qena bend structural high and Wadi Assiuty trough, respectively (Fig. 6.4). This Late Paleogene-Early Neogene rift segment is made up mainly of Lower Eocene cherty-limestones of the Thebes and Drunka formations with strata of general westward and northward dip-slopes. It represents a juvenile half-graben basin where the majority of extensional rift-related faults and folds populates the western shoulders with relatively dominant NE-dipping planes, contrarily to the southern segment. However, it was aborted as an immature asymmetrical early-rift segment.

The faults have dominant NNW Gulf of Suez Clysmic-trend and less frequent NW trends (Fig. 6.4, see also Fig. 5.5 \& Fig. 5.17). Both are linked and transferred throughout WNW, E-W and NW cross elements (Fig. 6.6 a-d). Linear narrow grabens and local shallow half-graben basins host the syn-rift Oligocene gravel and sands within the western grabens of the basin (Fig. 6.6 i).

The Eocene strata show regional horizontal latitudes, however tilted and rotated beds are found dragged locally along NNW extensional rift-related faults and folds. In addition, strongly rotated and deformed Eocene strata occur in some forced doubly plunged anticlines that were formed by rift-related basaltic intrusions such as along the NNW-oriented Gebel Gebeil west of Assiut, and Kolet El Fartilla, Kolet Abu Gilbana and Gebel Fahdi east of Sohag (see Fig. 5.15). The syn-rift Oligo-Miocene conglomerate and sandstone beds show occasional tilts along the hangingwalls of the graben-bounding faults (see Fig. 5.8 f). Slumped Eocene rocks are exposed along the faulted cliffs of the main graben of the Nile (Fig. $6.6 \mathrm{~g}$ ). 

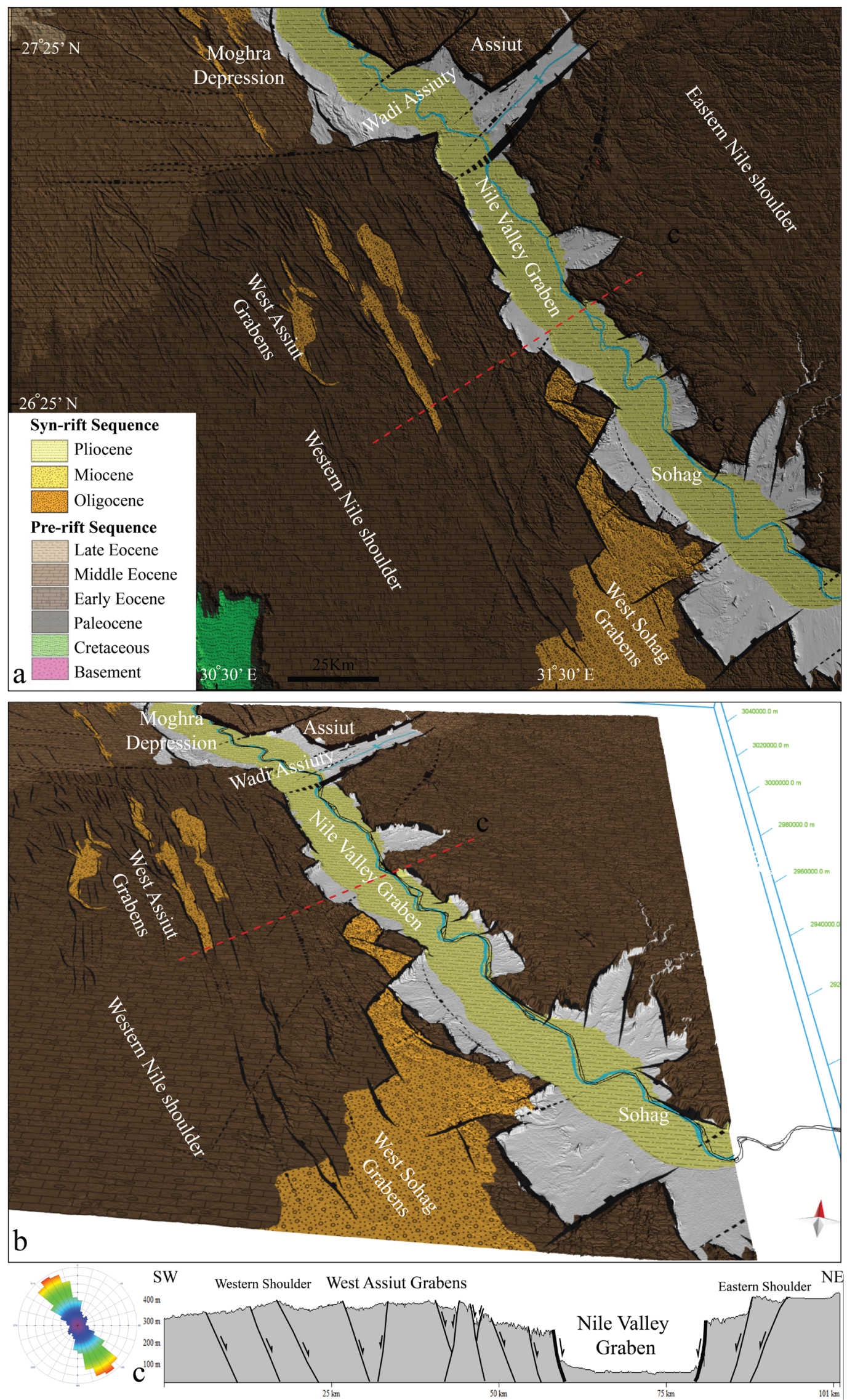

Fig. 6.4. Structural model of the Central Nile Rift Segment. This includes the Oligocene rift grabens/half-grabens of the west-central shoulders of the Nile basin as well as the Cretaceous NWstriking faults and E-W to NE-trending shears of Assiut basin and wadi Assiuty, further north. 


\subsection{Northern Rift Segment}

To the north of Wadi Assiuty transfer zone, most of the extensional faults migrate to the eastern shoulders of the Nile Valley where the northern rift segment extends between Assiut, Minia and Beni Suef governorates (Fig. 6.5). It comprises two Cretaceous rift basins, the southern NNW-oriented Assiut basin and the northern Beni Suef basin of NW orientation (see Fig. 4.7 \& Fig. 4.8). The Beni Suef basin extends further to the west and crosses the present-day Nile Valley. Both were developed during the Early Cretaceous rifting phases similar to the basins of the southern rift segments, and were also rejuvenated during the Late Oligocene-Early Miocene extension along the Nile rift.

This segment hosts the majority of the proposed rift-related volcanism to the east of the ancestral Nile in the area between Gebel Samalut in the south, East of Mina, and further northwest at Qaret El-Zurq, west of the Fayium depression (Fig. 6.5). It also represents a regional horst structure that is bounded from the east and west by two structural troughs and incisions of Wadi Qena and the Nile Valley, respectively. The frequency of faults increases toward the main graben of the Nile Valley (see Fig. 5.1).

The northern rift segment is made up mostly of Middle Eocene carbonates of the Minia and Samalut formations with strata of general westward dip-slopes (Fig. 6.5). Most of the Middle Eocene beds are horizontal, however occasional tilting and rotation occur along faults (Fig. 6.6 e). These faults have dominant NNW trends that change into NW further north in the footwalland hangingwalls of the Beni Suef Basin as well as along the shoulders of Wadi Tarfa. The Eocene rocks are dissected by hundreds of NNW-striking faults that have relatively dominant SW dipping planes, contrarily to the central segment. They form narrow linear graben and horst blocks that extend for tens of kilometres and host Neogene sediments (see Fig. 5.1). The faults in the northern rift segment extend for long distances with relatively small amounts of vertical displacements that range between a few tens of meters to hundreds along the NW bounding faults of Wadi Tarfa and Beni Suef Grabens (Fig. 6.5c). 

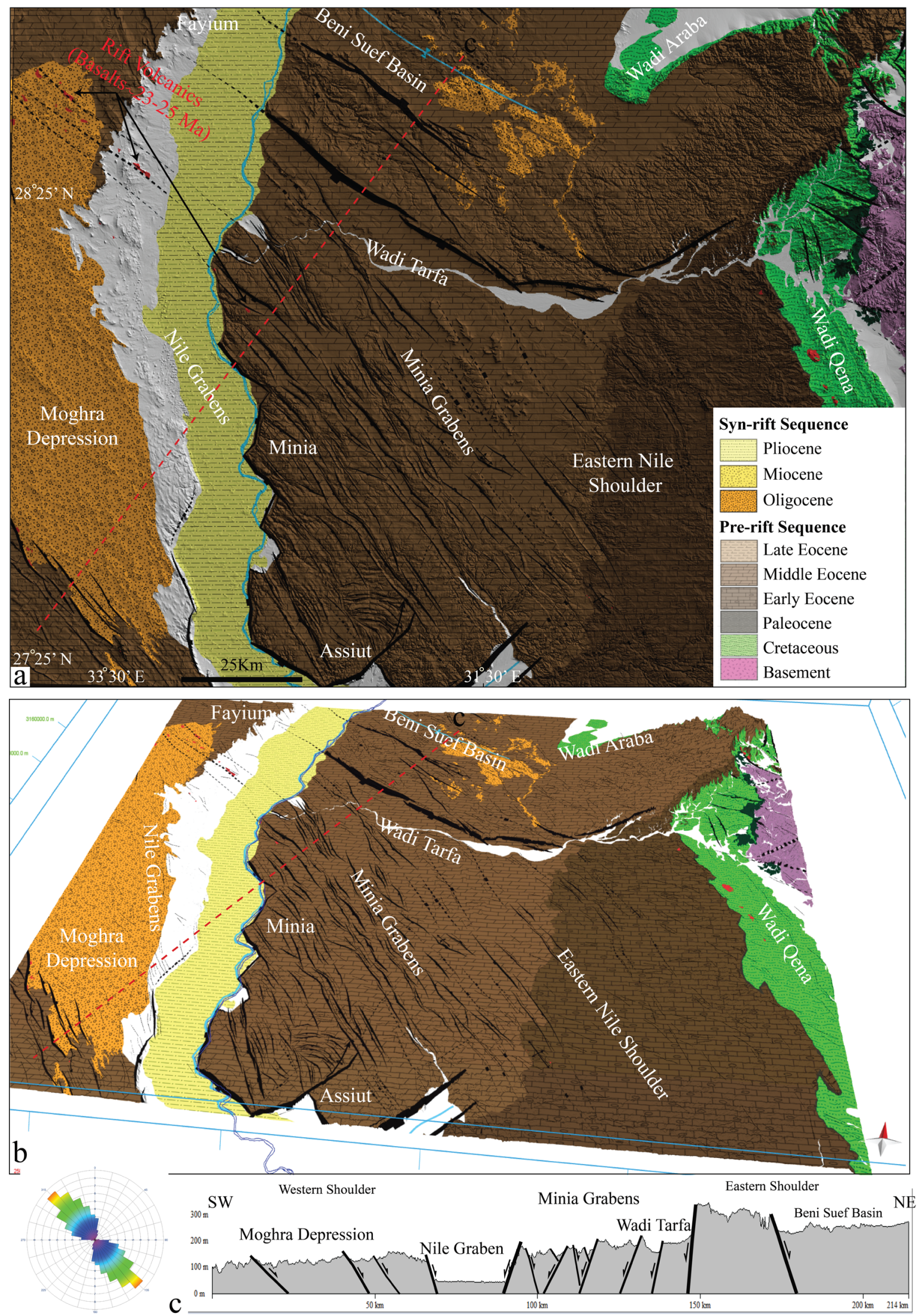

Fig. 6.5. Structural model of the Northern Nile Rift Segment. This hosts the Oligocene NNW-oriented grabens of Minia basin, and the NW-oriented Early Cretaceous Beni Suef basin and its bounding faults, which were reactivated during the Late Oligocene Nile rifting. The western extents comprise the Moghra graben and most of the rift-related basalt dikes and flows ( 25-23 Ma, this work). The inset rose diagram shows the dominant trends of the rift structures and basalt dikes. 

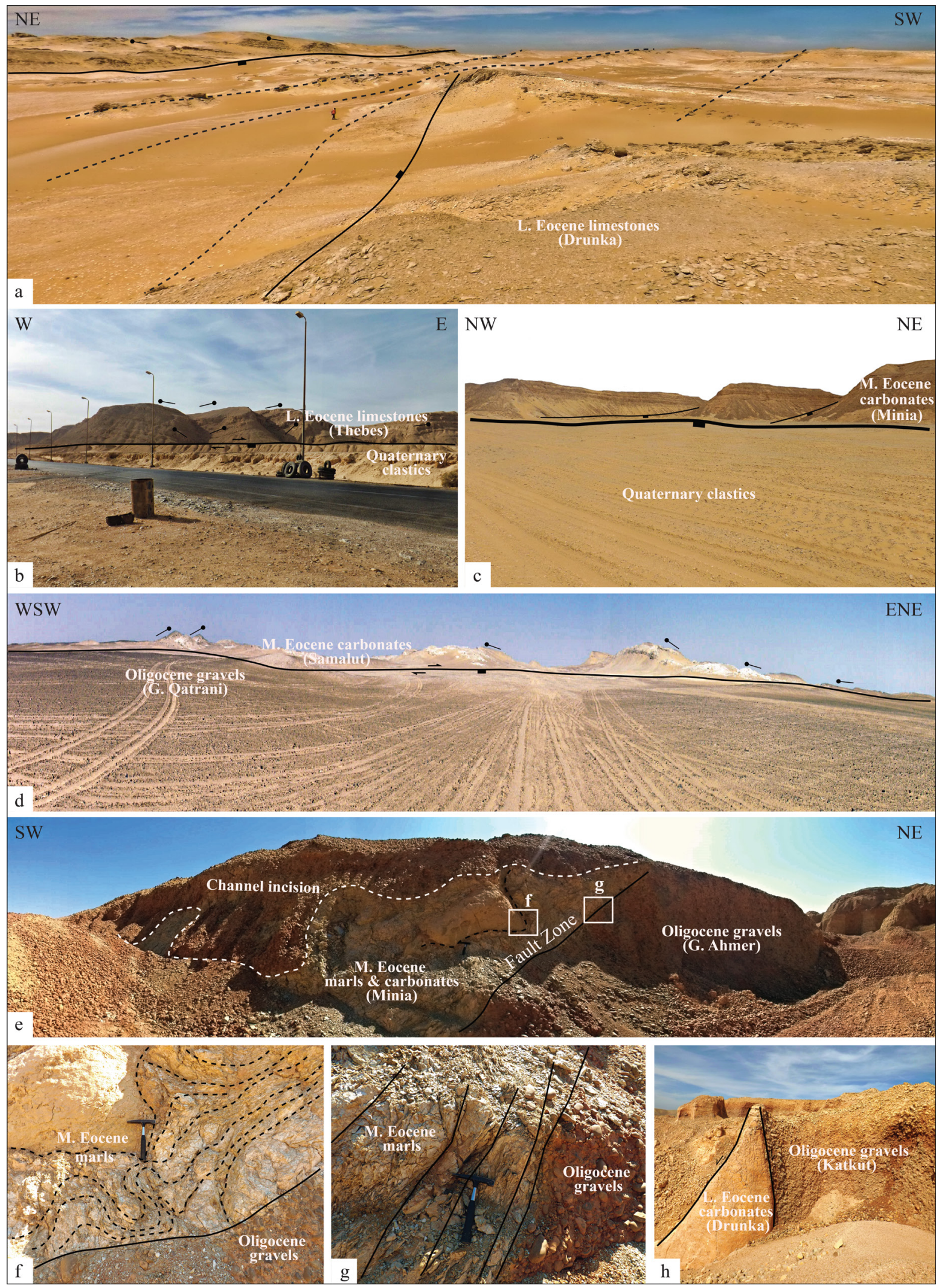

Fig. 6.6. Field occurrences of the extensional faults that controlled Oligoene sedimentation of the Central and Northern Nile Rift Segments. a) NNW-striking faults west of the Nile extending for kilometers with minor amounts of vertical throws. b) Rift-orthogonal dextral E-W oriented oblique-slip fault bounds the southern extents of the central rift segment. c) Linkedfault pattern of rift-parallel and rift-orthogonal elements in the Minia grabens, northern rift segment. d) Major ENE-striking dextral fault bounding the northern margins of the Moghra basin, notice the folding formed in the footwalls of the fault. e) Panoramic view for one of the syn-rift juvenile grabens/basins west of the northern segment, near Minia. It hosts faultbounded channel incisions filled with syn-rift Oligocene gravels overlying unconformably strongly deformed marls and carbonates of the Middle Eocene Minia Formation (f). g) Fault zone forming the boundary between the syn-(Oligocene gravels) and pre-rift sediments (M. Eocene marls). h) Structurally-controlled channel incision, west Assiut. 
Similar to the central segment, the northern one represents an immature half-graben basin where the majority of extensional rift-related faults and volcanics populate the eastern shoulders of the ancestral Nile rift rather than the western side but with relatively dominant SW dipping planes. The rift-bounding faults of Assiut and Beni Suef basins are characterized by considerable tectonic subsidence with a thick accumulation of Syn rift Cretaceous sediments (see Fig. 4.7 \& Fig. 4.8). The mapped NNW- and NW-striking surface faults were formed as a result of reactivation along the deep-seated Cretaceous faults in both basins. The propagation of the northern rift segment were terminated further north by the rift-orthogonal shear zones, faults and folds of the Bahariya-Fayium structural belt as well as the northern massive thickening of the Mesozoic syn-rift sediments in the ENE and NW rift basins of the north Western Desert (Fig. 6.9 \& Fig. 6.10).

\subsection{The Grand Canyon of the Nile Rift Basin}

Here, I focus on the development of the northern part of the river, north to Beni Suef, which is interpreted as having both a relatively young age $\sim 7-6 \mathrm{Ma}$, and different tectonic evolution (Fig. 6.7). Gravity, 3D seismic and well data show the presence of a deeply buried canyon west of the northern modern Nile, and approximately parallel to its present-day NNE- to NEoriented course in the north (Fig. 6.7 \& Fig. 6.8). The U-shaped canyon is up to $13 \mathrm{~km}$ wide and attains a maximum depth of $\sim 2 \mathrm{~km}$, about as deep as the Grand Canyon of the Colorado River in Arizona, USA (Fig. 6.7b).

The canyon was cut into a rising plateau along deep-seated NNE- to NE-striking faults that formed at $\sim 90-80 \mathrm{Ma}$ as secondary shears to the main structures of the WNW-oriented Cretaceous Beni-Suef rift, and possibly have been later reactivated (Fig. 6.7b, see also Fig. 4.7). Uplift of the older Nile delta would be another reason for the shift of the NW Nile course into NNE direction (Fig. 6.8). The canyon formed as a result of severe erosion due to significant sea-level drop and desiccation of the Mediterranean (Messinian Crisis 7-6 Ma) and attained its maximum depth by $\sim 5 \mathrm{Ma}$, which was accompanied by continued progressive uplift of the north-eastern Egyptian terrain. The ancestral river(s) excavated and widened a vast channel that incised deeply into Upper Cretaceous sediments in the Beni-Suef basin. 

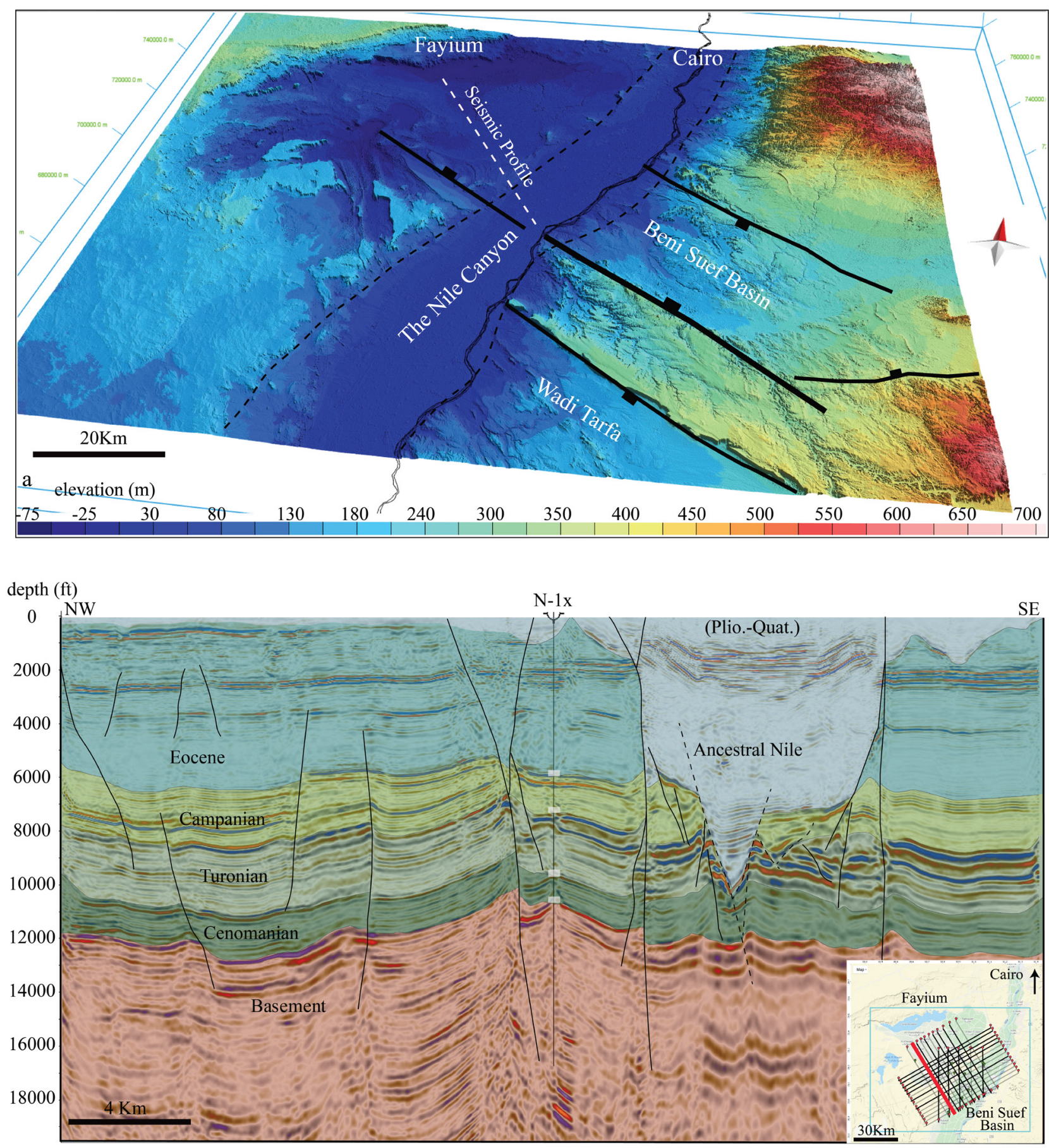

$\mathrm{b}$

Fig. 6.7. The Grand Canyon of the River Nile Rift System. a) DEM of the northern part of the Nile Canyon in the area between Beni Suef basin and Fayium depression. b) NW-SE seismic profile crossing the Nile Canyon and showing the deep incision and severe erosion of the Ancestral Eonile into the thick Cretaceous and Eocene rock sequences of Beni Suef basin. It demonstrates the structural control and influence of extensional faults on the incision of the Nile Rift Canyon. 

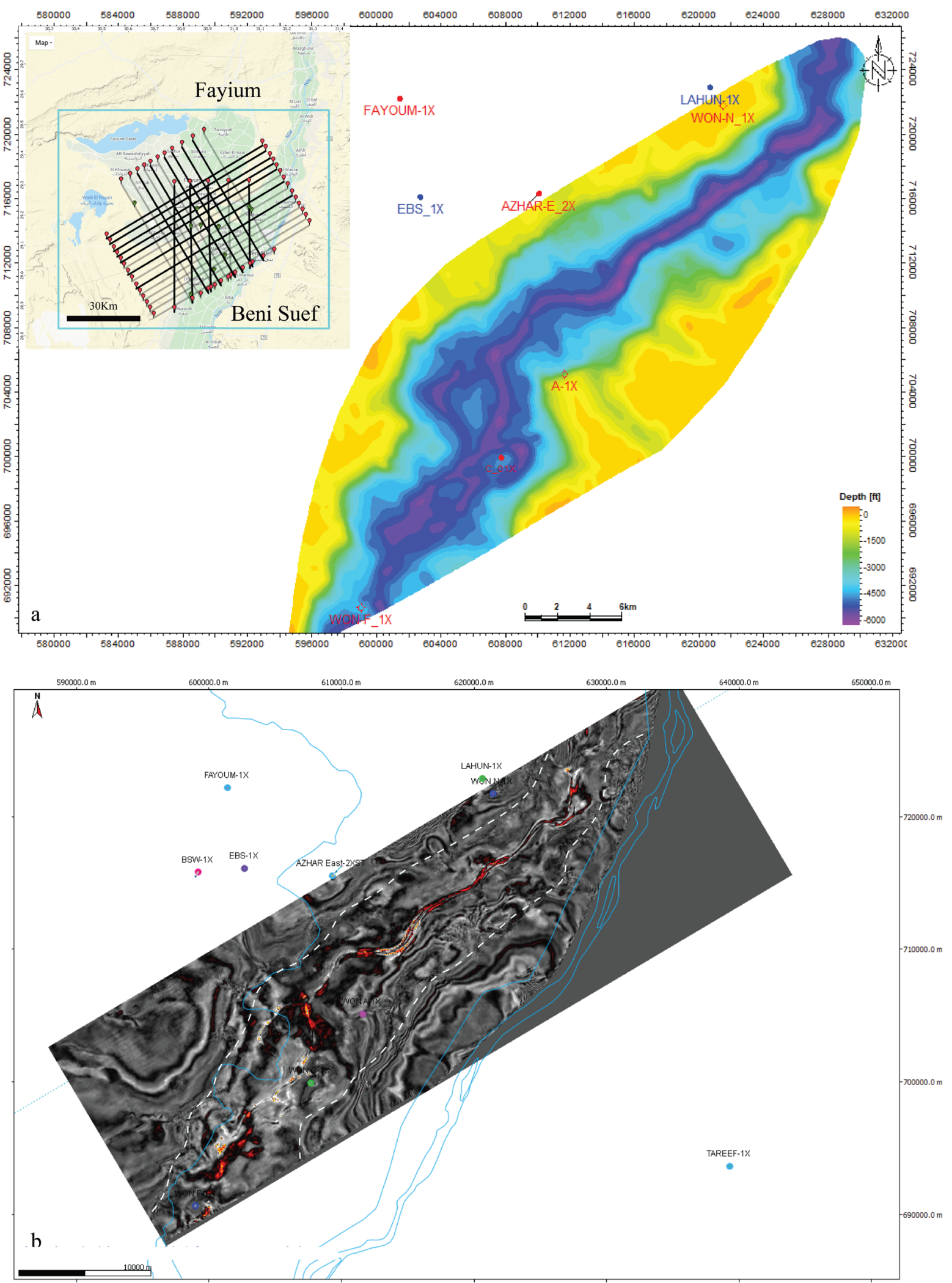

Fig. 6.8. Interpretation of 3D Seismic data of West Beni Suef Basin. a) Depth to base Nile Canyon map based on interpretation of $3 D$ seismic showing the geometry and architecture of the deep incision of the Canyon. b) Seismic attribute time slice on the Upper Cretaceous level of Beni Suef basin. It indicates the narrow and deep down-cutting of the early formed Eonile Canyon through the underlying strata. 


\subsection{The Nile Rift Propagation and Termination}

Rift basins generally terminate along the strike either abutting against another structure such as transcurrent or strike-slip faults that serve to transfer extension to another area or by spreading the extension to a broader zone of deformation that is not marked by a discrete rift (Bosworth, 1992) (e.g. Fig. 6.9 \& Fig. 6.10). The Nile Valley rift basins in southern and central Egypt appear to terminate at discrete structures that intersect the rifts at high angles (Fig. 6.1). E-W, ENE- and NE-striking Precambrian basement shear zones and strike-slip faults along the southern Nuqra basin, the central Qena-Bend structural high and the northern Wadi Assiuty trough acted as rift-terminating structures during the Cretaceous rifting phases (Fig. 6.10).

The rift-orthogonal and rift-oblique shears and physiographic heterogeneities were later reactivated during the Late Paleogene-Early Neogene extensional tectonics along the Nile, controlling the segmentation of the rift as well as positions of the transfer zones and flipping of the faults densities and polarities, rift-related clastics, folds and volcanism (Fig. 6.9 \& Fig. 6.10). These faults deviate from the classical length-displacement relation as they extend for tens of kilometres while displaying displacements of only tens of meters (Kim and Sanderson, 2005). Deep-seated strike-slip faults were rejuvenated in an oblique-divergence and propagated to the surface as linear furrows surrounded by oblique-slip WNW-, E-W and ENE-striking short fault segments (Fig. 6.9). The latter faults have different arrays and served as hard-linkage transfers between the NW-trending faults.

This study suggests that that the Late Paleogene-Early Neogene Nile Rift was abandoned at an early stage (Fig. 6.11 \& Fig. 6.12). We here propose some possible reasons for the rift abandonment: (1) Progressive concentration of extension and strain/stress localization onto the eastern Red Sea-Gulf of Suez rift, where the transfer of movement on this rift system aborted extension in central and southern Egypt and resulted in the abandonment of an embryonic rift stage (Fig. 6.12 b). (2) Strain/stress dissipation over wide Nile Valley rift shoulders $>300 \mathrm{~km}$ (Fig. 6.12a). (3) Obliquity of many reactivated pre-existing faults to the $\sim 23 \mathrm{Ma}$ regional $\left(\mathrm{N} 60^{\circ} \mathrm{E}\right)$ extension, with failure of newly developed rift-parallel faults. (4) Rifting confined to thicker (more brittle?) crust along the central part of the Nile. 
(5) Further structural control is that the northern rift termination and abortion coincide with a belt of ENE to NE-trending Syrian arc structures of the Bahariya-Fayium fault-fold belt, major basalt fissure eruptions and flows, and northward thickening of the pre-rift Mesozoic sediments in the rift basins of the North Western Desert along the Tethyan shelf(Fig. 6.9 \& Fig. 6.10 see also Fig. 2.11, Fig. 2.13 \& Fig. 4.2).

The present work proposes that an increase in the strength of the lithosphere across the Tethyan continental margin acted as a barrier to the northward propagation of the rift (Fig. 2.11). Fold and shear fault belts related to the Syrian Arc tectonics crosses diagonally the NW and NNWtrending rift structures along its course (Fig. 6.9 \& Fig. 6.10 b). The effect of these structures on the propagation and segmentation of the Nile rift system is observed in the southern Qena NE transfer zone (Fig. 6.12 a). The latter structural belt and the underlying basement uplift/horst block acted as an abutment that hindered the further northward propagation of the SW-dipping eastern border fault system of the Kharit, Nuqra and KomOmbo sub-basins of the southern rift segment (see Fig. 2.12). To the north of Qena fault belt, the Nile rift-border fault system transferred to the east as dominantly NE-dipping segments, which bound the western immature half-grabens of the central segment that is strongly terminated by Wadi Assiuty shear zone. Further to the north the northern rift segment transferred to the east with flipping of the faults polarities and population densities (Fig. $6.12 \mathrm{a}$ ) .

The propagating northern segment of the Nile rift encountered highly oblique and inherited major tectonic fabrics of The Bahariya-Fayium structural belt (Fig. 6.9 \& Fig. 6.10 b). These inherited fabrics are represented by: (1) ENE- o NE-striking complex strike-slip fault system which possibly extends further northeast to the Kattaniya inverted ridge. (2) Thick PreOligocene sedimentary pile $(7-10 \mathrm{Km})$ of the Mesozoic rift basin of the Western Desert, north to the Bahariya-Fayium Syrian Arc fault-fold belt. (3) Differential bedding-orientations and physiographic highs and lows that belong to the northern Egypt tectonic framework. These inherited fabrics acted as an oblique structural deficit zone for the NW-propagating extensional stresses that formed the earliest structures of the Late Oligocene Nile rifting phase (Fig. 6.9). 
The intersection of the embryonic northwestward propagating rift border faults with the oblique structures of the E-W and NE folds and faults in the northern extents of the Ancestral Nile rift witnessed the termination of most of the NW- and NNW-striking faults and branching of the main controlling faults into different E-W, NE, WNW and NW trends (Fig. 6.12 \& Fig. 6.13).

Consequently, the rifting stress/strain dissipated over a wide area and formed/rejuvenated swarms of NW-, E-W and ENE-striking extensional and oblique faults in the area between the Bahariya and Fayium depressions, extending further east the Nile Valley (Fig. 6.9). 


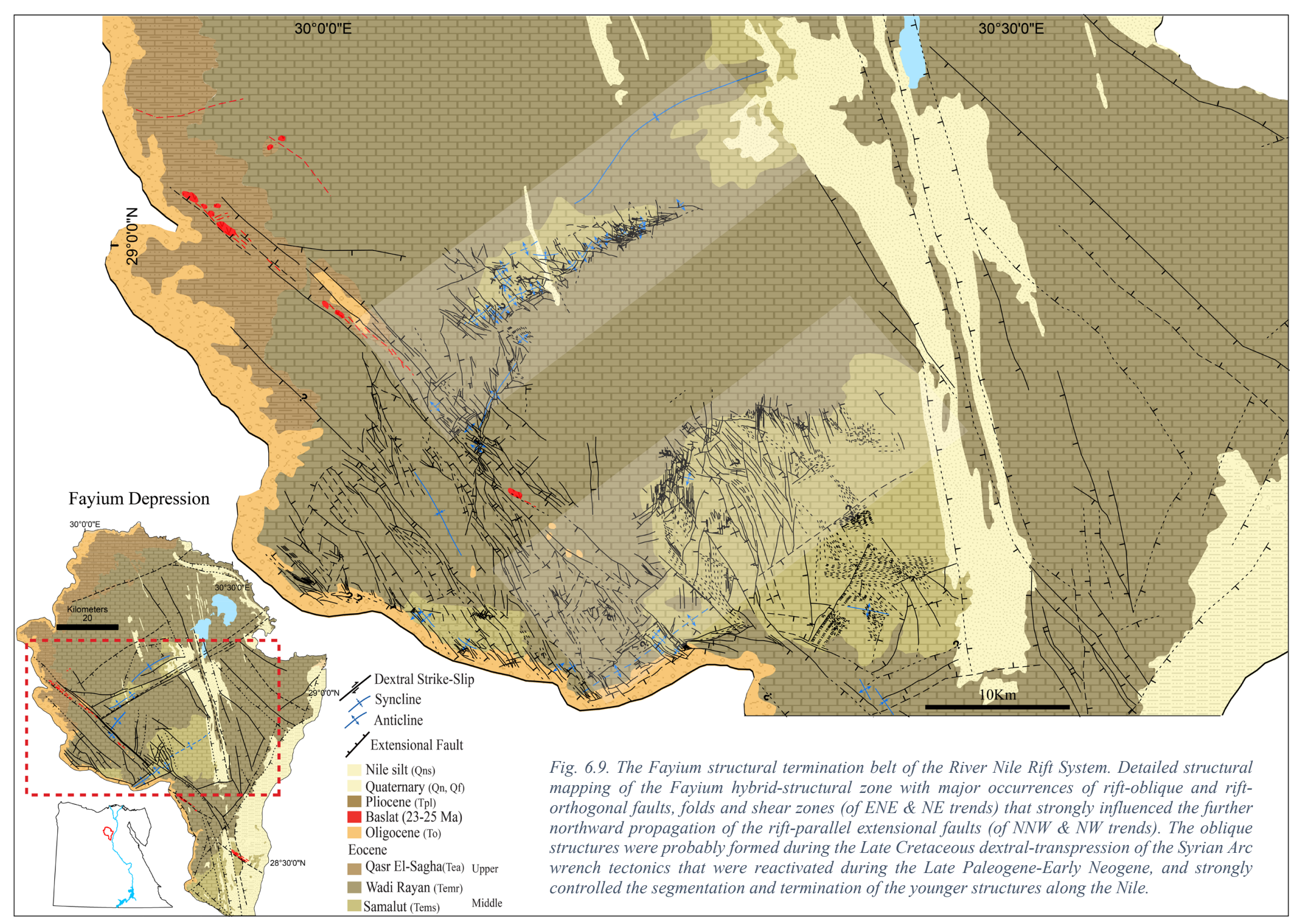



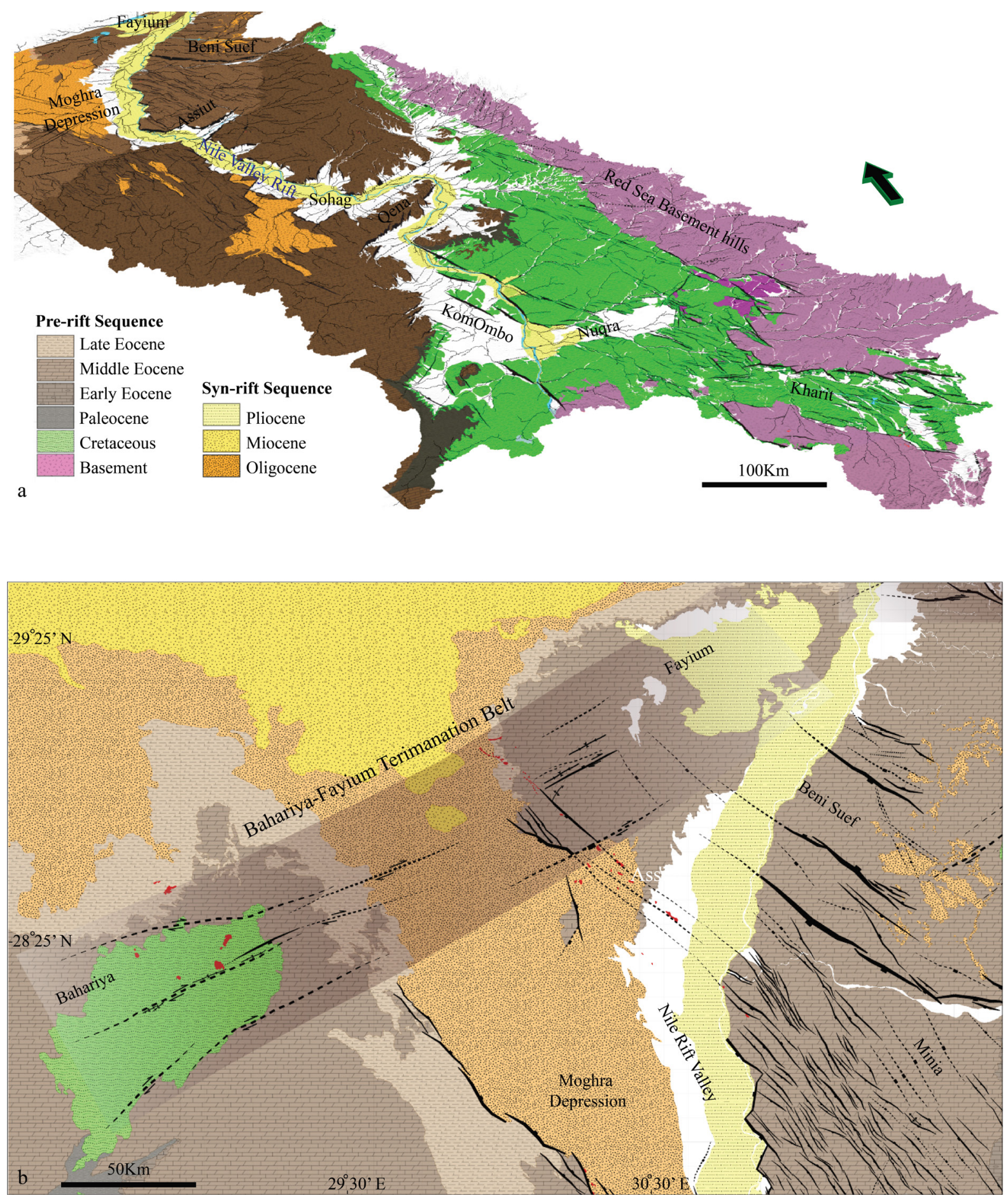

Fig. 6.10. The development and termination of the River Nile Rift System. a) 3D view showing the development of the drainage basin of the River Nile along the NW to NNW-trending Late Paleogene-Early Neogene Rift system. b) ENE to NE-oriented fold-fault structural belt that extends between Bahariya and Fayium to the north of the Nile rift. The highly oblique faults, folds and shear zones of this major structural belt terminated the further northward propagation of the proposed rift. 


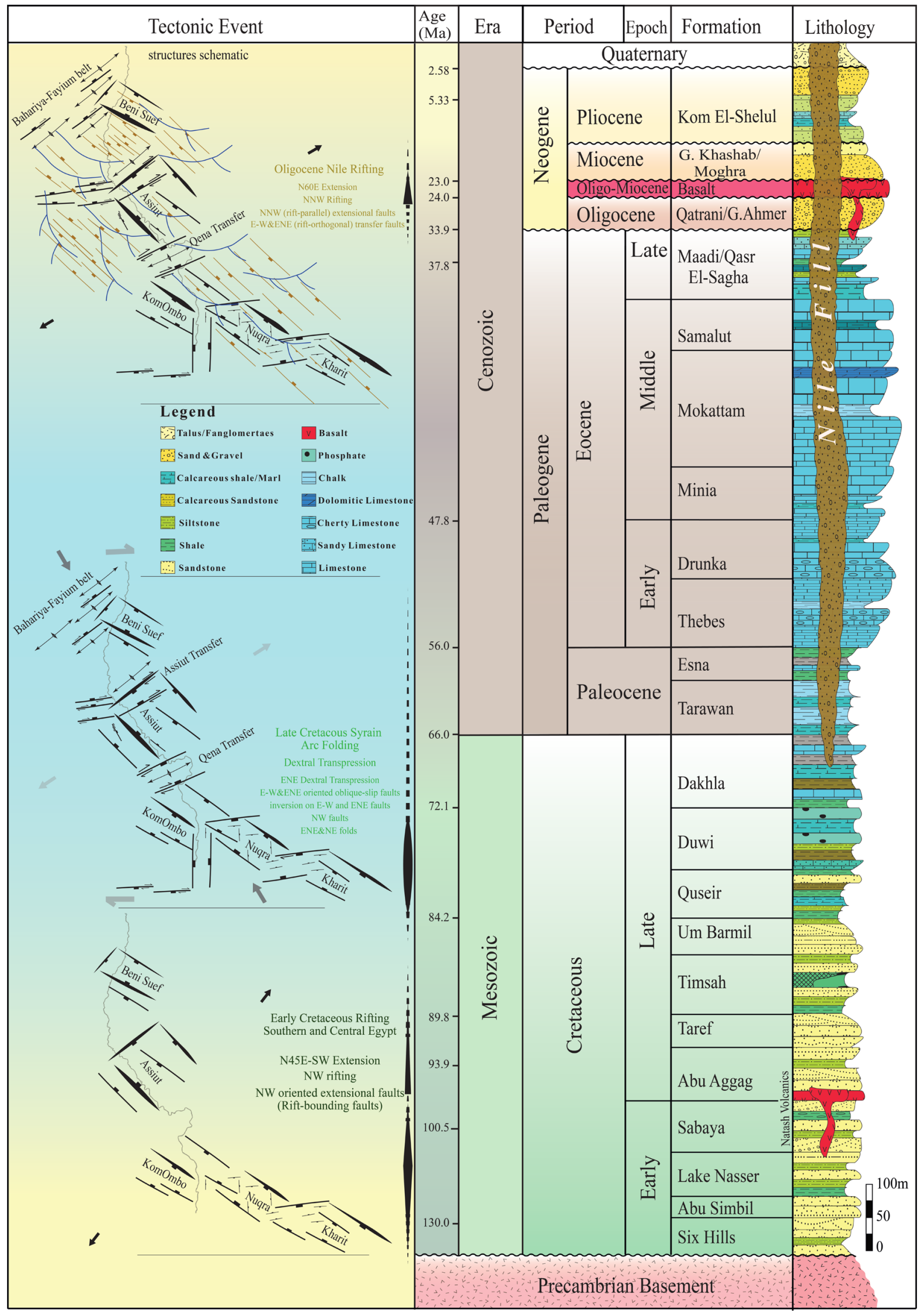

Fig. 6.11. Tectonostratigraphy of the Nile Valley area. The lift figure shows schematic structures that "roughly" summarizes the tectonic evolution of the Cretaceous and Late Oligocene rift basins along the Nile Valley and their influence on the development of the Nile's drainage systems and basins. The stratigraphic units were modified and compiled from Said (1962), (1990b); Klitzsch et al. (1987). Thicknesses are approximated. 


\subsection{The River Nile-Gulf of Suez Rifts}

There are many similarities between the two Late Oligocene NW-trending rifts, the proposed rift along the Nile valley in this study and the mature and well-developed Gulf of Suez rift system, but here we briefly highlight the main differences in the following points:

- The Late Oligocene Nile rift was reactivated along several interior Cretaceous rift basins that was formed earlier along the eastern and western shoulders of the valley such as Kharit Nuqra-KomOmbo, Assiut, and Beni Suef basins (Fig. 6.11). While, on the other hand, there are no clear evidence to prove that the Gulf of Suez rift has followed neither Mesozoic nor Paleozoic basins (Fig. 6.12 b). However, reactivation of NW and NNW-trending Precambrian basement shears (e.g. Najd Trend) controlled the tectonic evolution, geometry, and structural architecture of both rifts (see Fig. 4.4 \& Fig. 4.5). In addition, rift-orthogonal and rift-oblique basement shears and Late Cretaceous Syrian Arc structures controlled the segmentation of the two rifts as well as geometry and location of the transfer/accommodation zones (Fig. $6.12)$.

- The Gulf of Suez is a mature asymmetrical half-graben rift system of well-developed structural architecture and deeply-seated rift-bounding faults of huge vertical displacements that created deep sedimentary basins, which accommodated Oligocene-Neogene sedimentary accumulations of several kilometers thickness. This rift was abandoned at a very advanced stage, however some neotectonics and recent earthquakes show possible ongoing extensional activities along faults. While, the "primitive" Late Oligocene rifting phase along the course of the Nile valley was abandoned at a very early stage (Fig. 6.13).

- The Nile rift system shows a heterogeneous structural architecture of NW (Cretaceous origin) and NNW (Late Oligocene)-oriented faults while the Gulf of Suez has dominant NNWstriking faults (Fig. 6.13).

- The Late Oligocene-Early Miocene rifted-related basalt eruptions of the Nile rift might be 2-3 Ma older than those of the Gulf of Suez rift (based on the results of the present work's K-Ar age-dating of the basalt rocks along the Nile rift). 


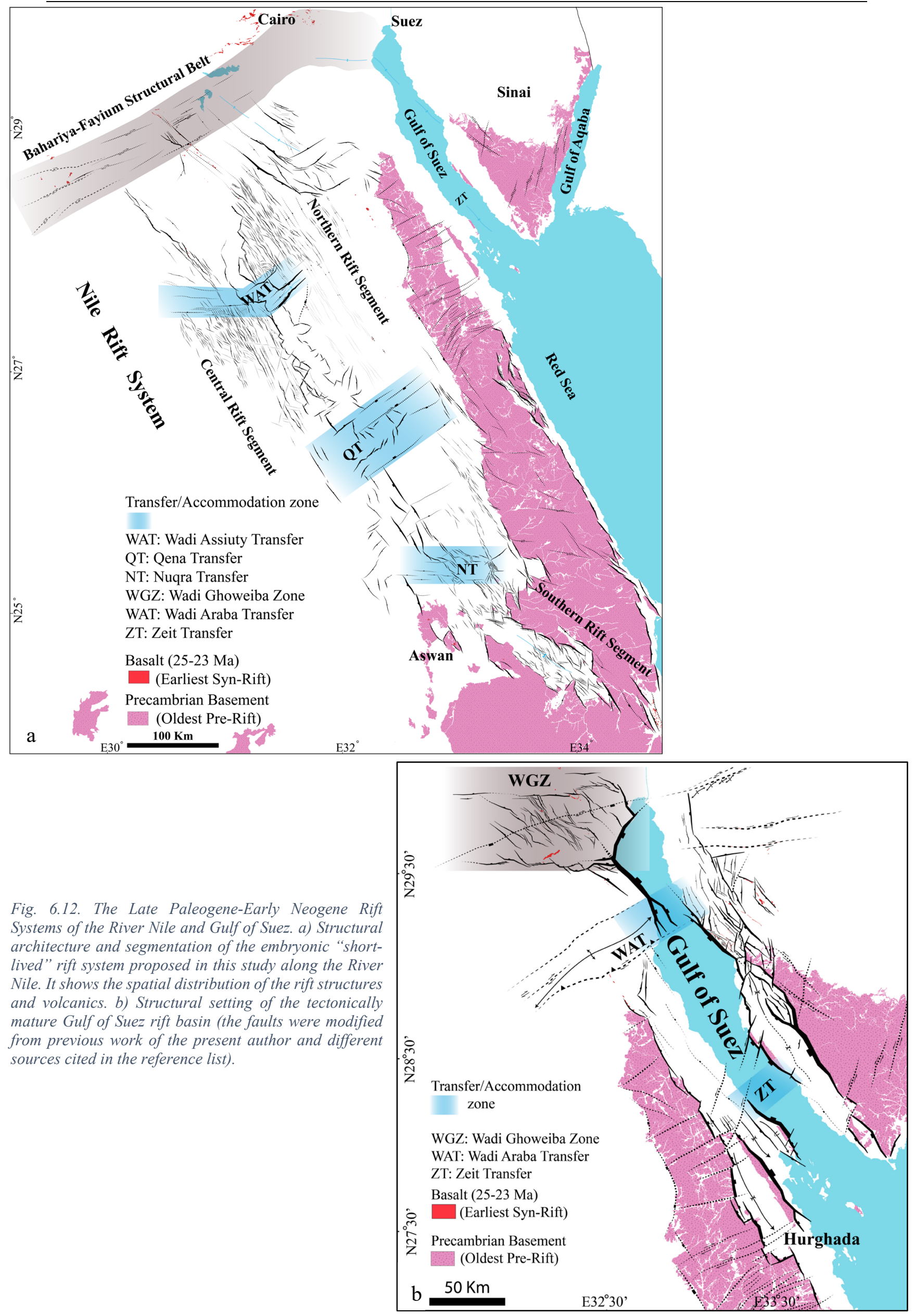




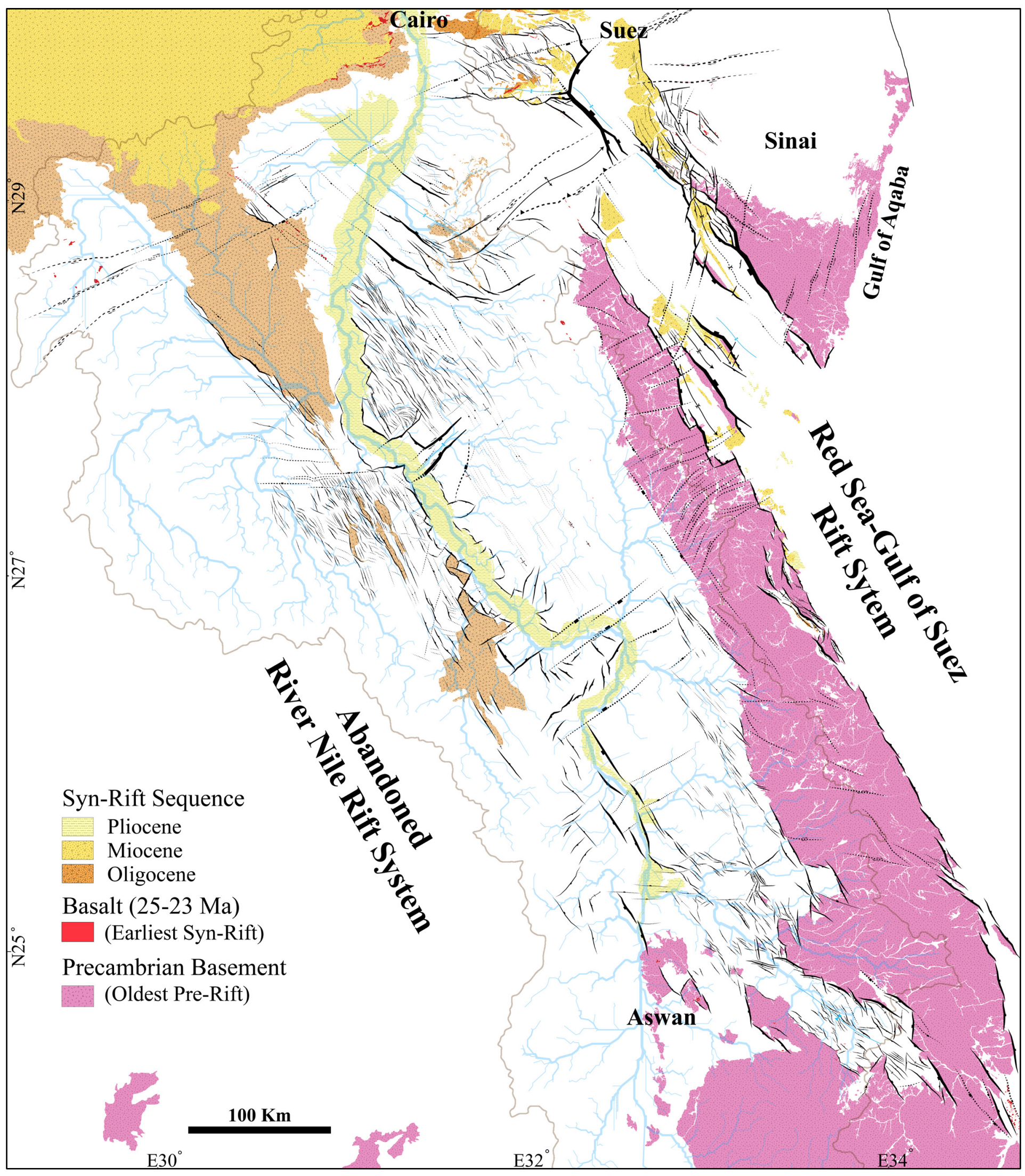

Fig. 6.13. The abandoned Nile Rift and the mature Red Sea-Gulf of Suez rift basins. It shows the evolution of the Nile's drainage basin along the proposed $N W$ - to $N N W$-oriented rift system along the course of the river. It indicates the spatial distribution of the rift structures, basalt volcanics and syn-to-post rift sediments. 


\section{Summary and Conclusions}

The origin and intricate history of the River Nile are still widely disputed. Some studies claimed that the Nile has formed at $\sim 7-5 \mathrm{Ma}$, while others have suggested a much longer evolution $\sim 30 \mathrm{Ma}$. Furthermore, the structural influence on the formation of the river and its drainage system are not well constrained. This study proposes that River Nile in Egypt has originally evolved along a NW-trending short-lived rift that was formed by NE-SW extension at $\sim 25-23 \mathrm{Ma}$, and was abandoned at a very primitive stage (Fig. 6.13). This study suggests a new rift model of the River Nile in Egypt, in which multiple surface and subsurface datasets were integrated.

The present study utilised the results of detailed fieldwork, processing and analysis of multispectral satellite images and high-resolution digital elevation models, as well as the interpretation of different gravity and magnetic anomaly models, and recently acquired high-resolution 2D and 3D seismic reflection data along the course of the Nile Valley. This was complemented with petrological and geochemical investigations, and K-Ar age-dating of 26 basalt samples scattered in 10 localities along the eastern and western extents of the Nile Valley. Based on the interpretation of these results, it was possible to recognize that the Ancestral River Nile(s) in Egypt have probably evolved along three main Late Paleogene-Early Neogene rift segments of NW to NNW orientation (southern, northern and central), that were transferred and terminated by highly-oblique zones of fold-fault belts, basement highs and shear zones of E-W and NE trends (Fig. 6.12). The evolution and abandonment of the rift segments and transfer zones were strongly influenced by the Early Cretaceous rift basins, as well as the Late Cretaceous Syrian Arc folds and wrench tectonics.

The onset of the main rifting phase in the Nile and evolution of its drainage system were contemporaneous with the initiation of the Red Sea-Gulf of Suez and East African rifts during the Late Oligocene $\sim 25 \mathrm{Ma}$, and the consequent exhumation and volcanism of the Red Sea hills (Fig. 6.11). This study suggests some evidences for a reactivated-rifting along numerous grabens within the eastern and western Eocene limestone plateaux of the modern Nile; among them are the Oligocene fluvial clastics/red beds, WNW-NNW-striking extensional fractures and widespread normal faulting, extensional fault-related folding, and Oligo-Miocene basalt dikes and flows $225-23 \mathrm{Ma}$. In addition, several NW-elongated steeply-dipping anticlines were also recognized along the eastern and western shoulders of the Nile Valley. These are made up of steeply dipping pre-rift Eocene and Cretaceous rocks, and were formed by local uplift that was driven by the rift-related volcanic intrusions ( $\sim 25 \mathrm{Ma})$. This study explained the strong control of the pre-existing structures and rift basins in southern, central and northern Egypt on the evolution, segmentation and termination of the Nile rift. 
The regional development of the drainage basins in the River Nile System was strongly controlled by the tectonic uplift that accompanied the uprising mantle plumes that resulted in the formation of dynamic topography associated with the intrusions of the large igneous provinces in Ethiopia (Afar) and Egypt, and the onset of the Red Sea, Gulf of Aden and East African rift systems. The multi-stage evolution of the Egyptian Nile's drainage systems was controlled by the Late Paleogene-Early Neogene short-lived rifting phase that was aborted at a very early "embryonic" stage. This was followed by the structurally-controlled deep incision of the ancestral Eonile Canyon along the faults of the aborted rift during the Messinian Salinity Crisis ( 6-5 Ma).

This study suggested some possible reasons for the abandonment of the "short-lived" River Nile rift system during the Late Paleogene-Early Neogene (25-23 Ma):

(1) Progressive concentration of extension and strain/stress localization onto the Red Sea-Gulf of Suez rift, where the transfer of movement on this rift system aborted extension in central Egypt and led to the abandonment of an embryonic rift.

(2) Strain/stress dissipation over wide rift shoulders $>300 \mathrm{~km}$. (3) Obliquity of many reactivated preexisting faults to the $\sim 23$ Ma regional $\left(\mathrm{N} 60^{\circ} \mathrm{E}\right)$ extension, with failure of newly developed rift-parallel faults.

(4) Rifting confined to thicker (more brittle?) crust along the central part of the Nile.

(5) Further structural control is that the northern rift termination and abortion coincide with oblique ENE to NE-trending "Syrian Arc" structures of the Bahariya-Fayium fold-fault bet, major basalt flows, and northward thickening of the Mesozoic pre-rift sediments of the ENE and NE half-graben basins of the North Western Desert along the Tethyan shelf. Moreover, we think that an increase in the strength of the lithosphere across the Tethyan continental margin acted as a barrier to the northward propagation of the rift. 


\section{Chapter 7 References}

Aal, A.A., Lelek, J.J., 2013. Structural development of the northern Sinai, Egypt and it's implications on the hydrocarbon prospectivity of the Mesozoic. GeoArabia, Journal of the Middle East Petroleum Geosciences 1, 15-30.

Abd-Allah, A., 2008. Structural evolution of the intracontinental Nile Valley rift, Egypt. Journal of Applied Geophysics 7, 49-75.

Abdelkareem, M., El-Baz, F., 2016. Mode of formation of the Nile Gorge in northern Egypt: a study by DEM-SRTM data and GIS analysis. Geol. J. 51 (5), 760-778.

Abdelkareem, M., Ghoneim, E., El-Baz, F., Askalany, M., 2012. New insight on paleoriver development in the Nile basin of the eastern Sahara. Journal of African Earth Sciences 62 (1), 35-40.

Abdelkhalek, A., 2014. Structural Modeling of Wadi Ghoweiba Segment, the Northwestern Sector of the Gulf of Suez Rift, Egypt. M. Sc. Thesis, Geology Dep., Fac. of Sci., Cairo Univ., Egypt, 163p.

Abdel-Rahman, M., El-Baz, F., 1979. Detection of a probable ancestral delta of the Nile River. Apollo-Soyuz Test Project Summary Science Report. Volume II: Earth Observations and Photography, NASA SP-412.

Abdelsalam, M.G., 2018. The Nile's journey through space and time: A geological perspective. Earth-Science Reviews 177, 742-773.

Adamson, D., McEvedy, R., Williams, M.J.A., 1993. Tectonic inheritance in the Nile basin and adjacent areas. Israel Journal of Earth-Sciences 41 (2-4), 75-85.

Adamson, D., Williams, F., 1982. Structural geology, tectonics and the control of drainage in the Nile basin, in: Williams, M.A.J., Faure, H. (Eds.), The Sahara and the Nile. Quaternary Environments and Prehistoric Occupation in Northern Africa. A.A. Balkema, Rotterdam, pp. $225-252$.

Akawy, A., El Din, K.G., 2006. Middle Eocene to Recent tectonicsin the Qina area, Upper Egypt. Neues Jahrbuch für Geologie und Paläontologie - Abhandlungen, 19-51. 
ALOS-AW3D30. ALOS Global Digital Surface Model "ALOS World 3D - 30m (AW3D30)"Japan Aerospace Exploration Agency-Earth Observing Satellite Program. https://www.eorc.jaxa.jp/ALOS/en/aw3d30/index.htm.

ALOS-PALSAR. Japan Aerospace Exploration Agency-Earth Observing Satellite Program ALOS-PALSAR. https://www.eorc.jaxa.jp/ALOS/en/about/palsar.htm.

ASTER. Jet Propulsion Laboratory-NASA-ASTER Web. https://asterweb.jpl.nasa.gov.

ASTERGDEM v.3. ASTER-Global Digital Elevation Model Version 3 (GDEM 003)- NASAJet Propulsion Laboratory. https://asterweb.jpl.nasa.gov/gdem.asp.

Baldridge, W.S., Keller, G.R., Braile, L.W., 1995. Continental rifting. A final perspective. Chapter 14, in: Olsen, K.H. (Ed.), Continental rifts. Evolution, structure, tectonics. Elsevier, Amsterdam, pp. 453-459.

Ball, J., 1909. On the origin of the Nile Valley and Gulf of Suez. Cairo Science Journal 3, 250 252.

Balmino, G., Vales, N., Bonvalot, S., Briais, A., 2012. Spherical harmonic modelling to ultrahigh degree of Bouguer and isostatic anomalies. J Geod 86 (7), 499-520.

Beadnell, H.J.L., 1900. The geological survey of Egypt. Geological Magazine 7 (Decade 4), 46-48.

Berry, L., Whiteman, A.J., 1968. The Nile in the Sudan. The Geographical Journal 134 (1), 1.

Bevan, T.G., Moustafa, A.R., 2012. Inverted rift-basins of northern Egypt, in: Roberts, D.G., Bally, A.W. (Eds.), Phanerozoic Rift Systems and Sedimentary Basins, 483-507.

Bonvalot, S., Balmino, G., Briais, A., Kuhn, M., Peyrefitte, A., Vales, N., Biancale, R., Gabalda, G., Moreaux, G., Reinquin, F., others, 2012. World Gravity Map., Bureau Gravimetrique International (BGI), map. CGMW-BGI-CNES-IRD Ed., Paris.

Bosworth, W., 1992. Mesozoic and early Tertiary rift tectonics in East Africa. Tectonophysics 209 (1-4), 115-137.

Bosworth, W., 2015. Geological Evolution of the Red Sea: Historical Background, Review, and Synthesis, in: Rasul, N.M.A., Stewart, I.C.F. (Eds.), The Red Sea. The Formation, 
Morphology, Oceanography and Environment of a Young Ocean Basin. Springer Berlin Heidelberg, Berlin, Heidelberg, pp. 45-78.

Bosworth, W., Abrams, M., Drummond, M., Thompson, M., 2015a. Jurassic Rift Initiation Source Rock in the Western Desert, Egypt—Relevance to Exploration in other Continental Rift Systems, in:, Petroleum Systems in "Rift" Basins. SEPM Society for Sedimentary Geology, pp. 615-650.

Bosworth, W., El-Hawat, A.S., Helgeson, D.E., Burke, K., 2008. Cyrenaican "shock absorber" and associated inversion strain shadow in the collision zone of northeast Africa. Geol 36 (9), 695.

Bosworth, W., Guiraud, R., Kessler, L.G., 1999. Late Cretaceous (ca. 84 Ma) compressive deformation of the stable platform of northeast Africa (Egypt): Far-field stress effects of the "Santonian event" and origin of the Syrian arc deformation belt. Geol 27 (7), 633.

Bosworth, W., Khalil, S.M., Ligi, M., Stockli, D.F., McClay, K.R., 2020. Geology of Egypt: The Northern Red Sea, in: Hamimi, Z., El-Barkooky, A., Martínez Frías, J., Fritz, H., Abd El-Rahman, Y. (Eds.), The Geology of Egypt. Springer Nature Switzerland AG, pp. 343374.

Bosworth, W., McClay, K., 2001. Structural and stratigraphic evolution of the Gulf of Suez rift, Egypt: a synthesis. Mémoires du Muséum national d'histoire naturelle (1993) 186, $567-606$.

Bosworth, W., McClay, K., Huchon, P., 2012. The Red Sea and Gulf of Aden basins, in: Roberts, D.G., Bally, A.W. (Eds.), Phanerozoic Passive Margins, Cratonic Basins and Global Tectonic Maps. Elsevier, Amsterdam, pp. 63-139.

Bosworth, W., Stockli, D.F., Helgeson, D.E., 2015b. Integrated outcrop, 3D seismic, and geochronologic interpretation of Red Sea dike-related deformation in the Western Desert, Egypt - The role of the 23Ma Cairo "mini-plume". Journal of African Earth Sciences 109, $107-119$. 
CGIAR. Consultative Group for International Agricultural Research CGIAR- SRTM 90m Digital Elevation Database v4.1. https://cgiarcsi.community/data/srtm-90m-digitalelevation-database-v4-1/.

Chénet, P.Y., Letouzey, J., 1983. Tectonique de la zone comprise entre Aba Durba et Gebel Mezzazat (Sinaï, Egypte) dans le contexte de l'évolution du rift de Suez. Bulletin Centres Recherche Exploration-Production Elf-Aquitaine 7, 201-215.

Chuvieco, E., 2016. Fundamentals of satellite remote sensing. An environmental approach / Emilio Chuvieco. CRC Press, Boca Raton.

Cloetingh, S., Ziegler, P.A., Beekman, F., Burov, E.B., Garcia-Castellanos, D., Matenco, L., 2015. Tectonic Models for the Evolution of Sedimentary Basins, in: Schubert, G. (Ed.), Crustal and Lithosphere Dynamics, 2nd ed. Elsevier, Amsterdam, pp. 513-592.

Colletta, B., Le Quellec, P., Letouzey, J., Moretti, I., 1988. Longitudinal evolution of the Suez rift structure (Egypt). Tectonophysics 153 (1-4), 221-233.

Darwish, M., El-Azabi, M., 1993. Contributions to the Miocene sequences along the western coast of the Gulf of Suez, Egypt. Egyptian Joural of Geology 37, 21-47.

DLR. Deutsches Zentrum für Luft und Raumfahrt-German Aerospace Center. https://www.dlr.de/EN/Home/home_node.html.

Dolson, J.C., 2020. The Petroleum Geology of Egypt and History of Exploration, in: Hamimi, Z., El-Barkooky, A., Martínez Frías, J., Fritz, H., Abd El-Rahman, Y. (Eds.), The Geology of Egypt. Springer Nature Switzerland AG, p. 636.

Dolson, J.C., Atta, M., Blanchard, D., Sehim, A., Villinski, J., Loutit, T., Romine, K., 2014. Egypt's Future Petroleum Resources: A Revised Look into the 21st Century, in: Marlow, L., Kendall, C., Yose, L. (Eds.), Petroleum systems of the Tethyan region, pp. 143-178.

Dolson, J.C., Boucher, P.J., Siok, J., Heppard, P.D., 2005. Key challenges to realizing full potential in an emerging giant gas province: Nile Delta/Mediterranean offshore, deep water, Egypt. Petroleum Geology Conference series 6 (1), 607-624.

Dolson, J.C., Shann, M.V., Matbouly, S., Hammouda, H., Rashed, R., 2000. Egypt in the Twenty-First Century: Petroleum Potential in Offshore Trends. GeoArabia 6 (2), 211-230. 
Dolson, J.C., Shann, M.V., Matbouly, S., Harwood, R., Rashed, R., Hammouda, H., 2001. The petroleum potential of Egypt, in: , Petroleum provinces of the twenty-first, AAPG Memoir 74, pp. $453-482$.

Ehrhardt, A., Hübscher, C., 2015. The Northern Red Sea in Transition from Rifting to DriftingLessons Learned from Ocean Deep, in: Rasul, N.M.A., Stewart, I.C.F. (Eds.), The Red Sea. The Formation, Morphology, Oceanography and Environment of a Young Ocean Basin. Springer Berlin Heidelberg, Berlin, Heidelberg, pp. 99-122.

El Barkooky, A.N., El-Araby, A., 1999. The Tertiary Red Beds of Abu Zenima area, West Central Sinai, Egypt: their stratigraphy and sedimentology, in: Proceedings of the Fourth International Conference on the Geology of the Arab World, pp. 621-642.

El-Bialy, M.Z., 2020. Precambrian Basement Complex of Egypt, in: Hamimi, Z., El-Barkooky, A., Martínez Frías, J., Fritz, H., Abd El-Rahman, Y. (Eds.), The Geology of Egypt. Springer Nature Switzerland AG, pp. 37-80.

EOS. Earth Observing System-NASA. https://eospso.nasa.gov/content/nasas-earth-observingsystem-project-science-office.

ESA. European Space Agency-Sentinel Online. https://sentinel.esa.int/web/sentinel/home.

ESRI, 2020. Environmental Systems Research Institute-ArcGIS Pro-Hillshade. https://pro.arcgis.com/en/pro-app/help/data/imagery/hillshade-function.htm.

Faccenna, C., Glišović, P., Forte, A., Becker, T.W., Garzanti, E., Sembroni, A., Gvirtzman, Z., 2019. Role of dynamic topography in sustaining the Nile River over 30 million years. Nat. Geosci. 12 (12), 1012-1017.

Fairhead, J.D., Green, C.M., Masterton, S.M., Guiraud, R., 2013. The role that plate tectonics, inferred stress changes and stratigraphic unconformities have on the evolution of the West and Central African Rift System and the Atlantic continental margins. Tectonophysics 594, $118-127$.

Garcia-Castellanos, D., Estrada, F., Jiménez-Munt, I., Gorini, C., Fernàndez, M., Vergés, J., Vicente, R. de, 2009. Catastrophic flood of the Mediterranean after the Messinian salinity crisis. Nature 462 (7274), 778-781. 
Garfunkel, Z., Bartov, Y., 1977. The tectonics of the Suez Rift. Israel Geological Survey, Bulletin 71, 1-44.

Goudie, A.S., 2005. The drainage of Africa since the Cretaceous. Geomorphology 67 (3-4), $437-456$.

GTOPO30. USGS EROS Archive - Digital Elevation - Global 30 Arc-Second Elevation. https://www.usgs.gov/centers/eros/science/usgs-eros-archive-digital-elevation-global-30arc-second-elevation-gtopo30?qt-science_center_objects=0\#qt-science_center_objects.

Guiraud, R., Bosworth, W., Thierry, J., Delplanque, A., 2005. Phanerozoic geological evolution of Northern and Central Africa: An overview. Journal of African Earth Sciences $43(1-3), 83-143$.

Guiraud, R., Issawi, B., Bosworth, W., 2001. Phanerozoic history of Egypt and surrounding areas. Peri-Tethys Memoir 6, 469-509.

Gupta, A. (Ed.), 2007. Large Rivers. Geomorphology and Management. John Wiley \& Sons, New York, NY, 730 pp.

Gupta, A., Slaymaker, O.c., Junk, W.J., 2020. Introducing large rivers, 1st ed. Wiley Blackwell, Chichester.

Han, L., Liu, Z., Ning, Y., Zhao, Z., 2018. Extraction and analysis of geological lineaments combining a DEM and remote sensing images from the northern Baoji loess area. Advances in Space Research 62 (9), 2480-2493.

Hantar, G., 1990. North Western Desert, in: Said, R. (Ed.), The geology of Egypt. Balkema, Rotterdam, pp. 293-319.

Haq, B.U., Hardenbol, J.A.N., Vail, P.R., 1987. Chronology of fluctuating sea levels since the triassic. Science 235 (4793), 1156-1167.

Heinzelin, J. de, Paepe, R., Wendorf, F., 1964. The geological history of the Nile Valley in Sudanese Nubia: Preliminary results. Contributions to the Prehistory of Nubia, 33-56.

Hirt, C., Claessens, S., Fecher, T., Kuhn, M., Pail, R., Rexer, M., 2013. New ultrahighresolution picture of Earth's gravity field. Geophys. Res. Lett. 40 (16), 4279-4283. 
Hobbs, W.H., 1904. Lineaments of the Atlantic Border region. GSA Bulletin 15 (1), 483-506.

Hsü, K.J., Montadert, L., Bernoulli, D., Cita, M.B., Erickson, A., Garrison, R.E., Kidd, R.B., Mèlierés, F., Müller, C., Wright, R., 1977. History of the Mediterranean salinity crisis. Nature 267 (5610), 399-403.

Hsü, K.J., Ryan, W.B.F., Cita, M.B., 1973. Late Miocene Desiccation of the Mediterranean. Nature 242 (5395), 240-244.

Hume, W.F., 1910. The origin of the Nile Valley in Egypt. Geological Magazine 7 (Decade 5), $385-389$.

Hume, W.F., 1929. The surface dislocations in Egypt and Sinai. their nature, and significance. Bull. soc. geograph. Egypte 17, 1-11.

Hunt, G.R., 1977. Spectral signatures of particular minerals in the visible and near infrared. Geophysics 42 (3), 501-513.

Issawi, B., Francis, M.H., Yousef, E.A.A., Osman, R., 2009. The Phanerozoic geology of Egypt: a geodynamic approach. Ministry of Petroleum, The Egyptian Mineral Resourse Authority. Special Publication No. 81.

Issawi, B., McCauley, J.F., 1992. The Cenozoic rivers of Egypt. the Nile problem, in: Adams, B., Friedman, R. (Eds.), The followers of Horus, Studies dedicated to Michael Allen Hoffman, Oxbow Monograph, Oxford, pp. 1-18.

Issawi, B., McCauley, J.F., 1993. The Cenozoic landscape of Egypt and its river systems. Annals of the Geological Survey of Egypt XIX, 357-384.

Issawi, B., Osman, R., Yousef, E.A.A., 2008. Egypt during the Cenozoic: geological history of the Nile River. Bulletin of the Tethys geological society, Cairo 3, 43-62.

JAXA. Japan Aerospace Exploration Agency. https://global.jaxa.jp.

Jensen, J.R., 2016. Introductory digital image processing. A remote sensing perspective / John R. Jensen. Pearson Education, Boston.

Jenson, S.K., 1991. Applications of hydrologic information automatically extracted from digital elevation models. Hydrol. Process. 5 (1), 31-44. 
Jenson, S.K., Domingue, J.O., 1988. Extracting topographic structure from digital elevation data for geographic information system analysis. Photogrammetric Engineering and Remote Sensing 54 (11), 1593-1600.

Keeley, M.L., 1994. Phanerozoic evolution of the basins of Northern Egypt and adjacent areas. Int J Earth Sci (Geol Rundsch) 83 (4).

Khalil, S.M., McClay, K.R., 2002. Extensional fault-related folding, northwestern Red Sea, Egypt. Journal of Structural Geology 24 (4), 743-762.

Khalil, S.M., McClay, K.R., 2017. 3D geometry and kinematic evolution of extensional faultrelated folds, NW Red Sea, Egypt, in: Childs, C., Holdsworth, R.E., Jackson, C.A.-L., Manzocchi, T., Walsh, J.J., Yielding, G. (Eds.), The Geometry and Growth of Normal Faults. Geological Society, London, Special Publications, 439, pp. 109-130.

Kim, Y.-S., Sanderson, D.J., 2005. The relationship between displacement and length of faults: a review. Earth-Science Reviews 68 (3-4), 317-334.

Klitzsch, E., 1984. Northwestern Sudan and bordering areas: geological development since Cambrian time. Berliner Geowissenschafte Abhandlungen 5 (A), 23-45.

Klitzsch, E., 1986. Plate tectonics and cratonal geology in Northeast Africa (Egypt, Sudan). International Journal of Earth Sciences : GR Geologische Rundschau 75 (3), 755-768.

Klitzsch, E., 1990. Paleozoic, in: Said, R. (Ed.), The geology of Egypt. Balkema, Rotterdam, pp. 393-406.

Klitzsch, E., List, F.K., Pöhlmann, G. (Eds.), 1987. Geological Map of Egypt. Scale 1:500,000. Technische Fachhochschule Berlin, Institute für Angewandte Geodäsie, Berlin, Germany. Egyptian General Petroleum Corporation, Cairo, Egypt.

Knox, J.C., 2007. The Mississippi River System, in: Gupta, A. (Ed.), Large Rivers. Geomorphology and Management. John Wiley \& Sons, New York, NY, pp. 145-182.

Krenkel, E., 1925. Geologie der Erde, Geologie, Afrikas, Volume I, Berlin, Gebrüder Borntraeger. 
Lambiase, J.J., Bosworth, W., 1995. Structural controls on sedimentation in continental rifts. Geological Society, London, Special Publications 80 (1), 117-144.

Landsat-8. USGS Landsat Missions-Landsat-8. https://www.usgs.gov/core-sciencesystems/nli/landsat/landsat-8?qt-science_support_page_related_con=0\#qtscience_support_page_related_con.

Lawson, A.C., 1927. The Valley of the Nile. Univ. Calif. (Berkley) Pubis., Publ. Geol. Sci. 29, $235-259$.

Lillesand, T.M., Kiefer, R.W., Chipman, J.W., 2015. Remote sensing and image interpretation. Wiley, Hoboken.

Liu, J.-G., Mason, P.J., 2016. Image processing and GIS for remote sensing. Techniques and applications / Jian Guo Liu and Philippa J. Mason, Department of Earth Science and Engineering, Imperial College London. Wiley Blackwell, Chichester, West Sussex.

Loutit, T., Allard, D., Dolson, J.C., Schruers, J., Laura, S., 2001. A New View of Egypt's Hydrocarbon Potential (abs.), in: Middle East and North Africa conference, London, UK.

Maxwell, T.A., Issawi, B., Haynes, C.V., 2010. Evidence for Pleistocene lakes in the Tushka region, south Egypt. Geol 38 (12), 1135-1138.

McClay, K.R., Nichols, G.J., Khalil, S.M., Darwish, M., Bosworth, W., 1998. Extensional tectonics and sedimentation, eastern Gulf of Suez, Egypt. Chapter D4, in: Purser, B.H., Bosence, D.W.J. (Eds.), Sedimentation and Tectonics in Rift Basins Red Sea:- Gulf of Aden. Springer Netherlands, Dordrecht, pp. 223-238.

McKenzie, D., 1978. Some remarks on the development of sedimentary basins. Earth and Planetary Science Letters 40 (1), 25-32.

Meneisy, M.Y., 1990. Vulcanicity, in: Said, R. (Ed.), The geology of Egypt. Balkema, Rotterdam, pp. 157-172.

METI, 2019. The Ministry of Economy, Trade and Industry of Japan-ASTER GDEM. https://ssl.jspacesystems.or.jp/ersdac/GDEM/E/. 
Meyer, B., Saltus, R., Chulliat, A., 2017. EMAG2v3: Earth Magnetic Anomaly Grid (2-arcminute resolution). Version 3. NOAA National Centers for Environmental Information. https://doi.org/10.7289/V5H70CVX.

Montenat, C., Ott D'Estevou, P., Jarrige, J.-J., Richert, J.-P., 1998. Rift development in the Gulf of Suez and the north-western Red Sea: structural aspects and related sedimentary processes, in: Purser, B.H., Bosence, D.W.J. (Eds.), Sedimentation and Tectonics in Rift Basins Red Sea:- Gulf of Aden. Springer Netherlands, Dordrecht, pp. 97-116.

Morgan, P., 1990. Egypt in the framework of global tectonics, in: Said, R. (Ed.), The geology of Egypt. Balkema, Rotterdam, pp. 91-111.

Mostafa, A., Sehim, A., Farouk, O., 2016. Hydrocarbon assessments of interior Cretaceous rift basins, upper Egypt, in: The proceeding 8th Mediterranean Offshore Conference (MOC), Alexandria, Egypt.

Moustafa, A.R., 2008. Mesozoic-Cenozoic basin evolution in the northern Western Desert of Egypt. Geology of East Libya, Earth Science Society of Libya (Tripoli, Libya) 3, 29-46.

Moustafa, A.R., 2020. Mesozoic-Cenozoic Deformation History of Egypt, in: Hamimi, Z., ElBarkooky, A., Martínez Frías, J., Fritz, H., Abd El-Rahman, Y. (Eds.), The Geology of Egypt. Springer Nature Switzerland AG, pp. 253-294.

Moustafa, A.R., Badrawi, R.E., Gibali, H., 1998. Pervasive E-ENE-oriented faults in Northern Egypt and their effect on the development and inversion of prolific sedimentary basins, in: , 14th Petroleum Conference. The Egyptian General Petroleum Corporation, Cairo, Egypt, pp. 51-67.

Moustafa, A.R., El Shaarawy, O.A., 1987. Tectonic setting of the northern Gulf of Suez. Bull Egyptian Geophysical Soci 5, 339-368.

Moustafa, A.R., El-Raey, A.K., 1993. Structural characteristics of the Suez rift margins. Geol Rundsch 82 (1), 101-109.

Moustafa, A.R., Khalil, M.H., 1990. Structural Charecterstics and Tectonic Evolution of North Sinai Fold Belts, in: Said, R. (Ed.), The geology of Egypt. Balkema, Rotterdam, pp. 381389. 
Moustafa, A.R., Khalil, M.H., 1995. SUPERPOSED DEFORMATION IN THE NORTHERN SUEZ RIFT, EGYPT: RELEVANCE TO HYDROCARBONS EXPLORATION. J Petroleum Geol 18 (3), 245-266.

Nagati, M., 1986. Possible Mesozoic rifts in Upper Egypt: an analogy with the geology of Yemen-Somalia rift basins, in: Proceeding of the 8th petroleum exploration conference, pp. $205-231$.

NASA. National Aeronautics and Space Administration-Earthdata. https://earthdata.nasa.gov.

O'LEARY, D.W., FRIEDMAN, J.D., POHN, H.A., 1976. Lineament, linear, lineation: Some proposed new standards for old terms. Geol Soc America Bull 87 (10), 1463.

Patton, T.L., Moustafa, A.R., Nelson, R.A., Abdine, S.A., 1994. Tectonic Evolution and Structural Setting of the Suez Rift: Chapter 1: Part I. Type Basin: Gulf of Suez, in: Landon, S.M. (Ed.), Interior rift basins. American Association of Petroleum Geologists, AAPG memoir 59, Tulsa, Okla., pp. 7-55.

PCI Geomtica. PCI Geomatics Company, MARKHAM, Ontario, Canada. https://www.pcigeomatics.com/software/geomatica/education.

Qari, M.H.T., 2011. Lineament extraction from multi-resolution satellite imagery: a pilot study on Wadi Bani Malik, Jeddah, Kingdom of Saudi Arabia. Arab J Geosci 4 (7-8), 1363-1371.

Rasul, N.M.A., Stewart, I.C.F. (Eds.), 2015. The Red Sea. The Formation, Morphology, Oceanography and Environment of a Young Ocean Basin. Springer Berlin Heidelberg, Berlin, Heidelberg.

Richardson, M., Arthur, M.A., 1988. The Gulf of Suez-northern Red Sea Neogene rift: a quantitive basin analysis. Marine and Petroleum Geology 5 (3), 247-270.

Roberts, D.G., Bally, A.W., 2012. From rifts to passive margins: A continuum of extension, in: Roberts, D.G., Bally, A.W. (Eds.), Phanerozoic Rift Systems and Sedimentary Basins, pp. 19-31.

Robertson, A.H.F., Dixon, J.E., Brown, S., Collins, A., Morris, A., Pickett, E., Sharp, I., Ustaömer, T., 1996. Alternative tectonic models for the Late Palaeozoic-Early Tertiary 
development of Tethys in the Eastern Mediterranean region. Geological Society, London, Special Publications 105 (1), 239-263.

Rzóska, J., 1978. On the Nature of Rivers. With case stories of Nile, Zaire and Amazon. Springer Netherlands, Dordrecht, 67 pp.

Said, R., 1962. The geology of Egypt. Elsevier Pub. Co. [distributors for the U.S.: American Elsevier Pub. Co. New York], Amsterdam, New York, xv, 377.

Said, R., 1981. The geological evolution of the river Nile. Springer, New York, VIII, 151 S. (eng).

Said, R., 1990a. Cretaceous paleogeographic maps, in: Said, R. (Ed.), The geology of Egypt. Balkema, Rotterdam, pp. 439-449.

Said, R. (Ed.), 1990b. The geology of Egypt. Balkema, Rotterdam, X, 734 S. (eng).

Said, R., 1993. The river Nile. Geology, hydrology and utilization, 1st ed. Pergamon Press, Oxford, XII, 320 S. (eng).

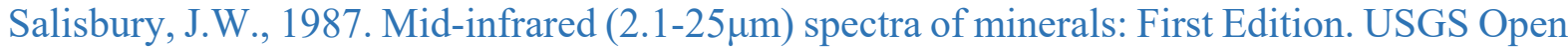
File Report, 87-263.

Sampietro, D., Mansi, A., Capponi, M., 2018. A New Tool for Airborne Gravimetry Survey Simulation. Geosciences 8 (8), 292.

Sandford, K.S., 1928. The relations of Nile and Faiyum in Pliocene and Pleistocene time. Nature 121, 670-671.

Sandford, K.S., 1929. The Pliocene and Pleistocene deposits of Wadi Qena and of the Nile Valley between Luxor and Assiut. Quart. J. Geol. Soc. London 75, 493-548.

Sandford, K.S., 1934. Paleolithic man and the Nile Valley in upper and middle Egypt. Chicago Univ., Oriental Inst. Publ. 3, 1-134.

Schlische, R.W., 1995. Geometry and Origin of Fault-Related Folds in Extensional Settings. AAPG Bulletin 79 (11), 1661-1678. 
Schlische, R.W.O.Y., 1992. Structural and stratigraphic development of the Newark extensional basin, eastern North America: Evidence for the growth of the basin and its bounding structures. Geological Society of America Bulletin 104 (10), 1246-1263.

Schull, T.J., 1988. Rift Basins of Interior Sudan: Petroleum Exploration and Discovery. AAPG Bulletin 72 (10), 1128-1142.

Seif, E.-S.S.A., 2015. Geological evolution of Nile Valley, west Sohag, Upper Egypt: a geotechnical perception. Arab J Geosci 8 (12), 11049-11072.

Selley, R.C., 1997. African basins. Elsevier Science, Amsterdam, New York, xvii, 394.

Sentinel-1. European Space Agency - Copernicus Sentinel-1 mission. https://sentinel.esa.int/web/sentinel/missions/sentinel-1.

Sentinel-2. European Space Agency - Copernicus Sentinel-2 mission. https://sentinel.esa.int/web/sentinel/missions/sentinel-2.

Sentinel-2. European Space Agency - Copernicus Sentinel-2 mission. https://sentinel.esa.int/web/sentinel/missions/sentinel-2.

Sestini, G., 1984. Tectonic and sedimentary history of the NE African margin (Egypt—Libya). Geological Society, London, Special Publications 17 (1), 161-175.

Sobh, M., Mansi, A.H., Campbell, S., Ebbing, J., 2019. Regional Gravity Field Model of Egypt Based on Satellite and Terrestrial Data. Pure Appl. Geophys. 176 (2), 767-786.

SRTM. NASA Jet Propulsion Laboratory- Shuttle Radar Topography Mission. https://www2.jpl.nasa.gov/srtm/.

Steffan, Robertson, Kirtsen, 2000. Egypt Area Regional Study (EARS). Final Report, SRK Project Code AP151/AP152, SRK Consulting.

Stern, Abdelsalam, 1996. The Origin of the Great Bend of the Nile from SIR-C/X-SAR Imagery. Science 274 (5293), 1696-1698.

Suess, E., 1904. The face of the earth. Clarendon Press, Oxford. I, 604 pp. 
Taha, M.A., 1992. Mesozoic rift basins in Egypt: their southern extension and impact on future exploration, in: Proceedings of the EGPC 11th Exploration and Production Conference, Cairo. Egyptian General Petroleum Corporation Bulletin, pp. 1-19.

Talbot, M.R., Williams, M.A.J., 2009. Cenozoic Evolution of the Nile Basin, in: Dumont, H.J. (Ed.), The Nile. Origin, environments, limnology, and human use. Springer, Dordrecht Netherlands, pp. 37-60.

TanDEM-X. Earth Observation Center (EOC) of the German Aerospace Center (DLR)TanDEM-X Digital Elevation Model. https://geoservice.dlr.de/web/dataguide/tdm90/.

Tandon, S.K., Sinha, R., 2007. Geology of Large River System, in: Gupta, A. (Ed.), Large Rivers. Geomorphology and Management. John Wiley \& Sons, New York, NY, pp. 7-28.

Tewksbury, B.J., Tarabees, E.A., Mehrtens, C.J., 2017. Origin of an extensive network of nontectonic synclines in Eocene limestones of the Western Desert, Egypt. Journal of African Earth Sciences 136, 148-167.

Underwood, C.J., King, C., Steurbaut, E., 2013. Eocene initiation of Nile drainage due to East African uplift. Palaeogeography, Palaeoclimatology, Palaeoecology 392, 138-145.

USGS. United States Geological Survey-EarthExplorer. https://earthexplorer.usgs.gov.

Vassilas, N., Perantonis, S., Charou, E., Tsenoglou, T., Stefouli, M., Varoufakis, S., 2002. Delineation of lineaments from satellite data based on efficient neural network and pattern recognition techniques. 2nd Hellenic Conf. on AI, SETN-2002, 11-12 April 2002, Thessaloniki, Greece,Proceedings Companion Volume, 355-366.

Wescott, W.A., Atta, M., Blanchard, D.C., Cole, R.M., Georgeson, S.T., Miller, D.A., O’Hayer, W.W., Wilson, A.D., Dolson, J.C., Sehim, A., 2011. Jurassic Rift Architecture in the Northeastern Western Desert, Egypt. AAPG International Conference and Exhibition, Milan, Italy, AAPG Search and Discovery Article no. 10379, 2011.

Williams, M.A.J., 2009. Late Pleistocene and Holocene environments in the Nile basin. Global and Planetary Change 69 (1-2), 1-15. 
Williams, M.A.J., Williams, F.M., 1982. Evolution of the Nile basin, in: Williams, M.A.J., Faure, H. (Eds.), The Sahara and the Nile. Quaternary Environments and Prehistoric Occupation in Northern Africa. A.A. Balkema, Rotterdam, pp. 207-224.

Wit, M.J. de, 2003. MADAGASCAR : Heads It's a Continent, Tails It's an Island. Annu. Rev. Earth Planet. Sci. 31 (1), 213-248.

Wood, B., Zakariya, A., Abdel Hady, A., 2012. Resetting the Geological Framework of the Al Baraka Field, Komombo Concession, Upper Egypt. GEO 2012, cp-287-00058.

Woodward, J.C., Macklin, M.G., Krom, M.D., Williams, M.A.J., 2007. The Nile: Evolution, Quaternary River Environments and Material Fluxes, in: Gupta, A. (Ed.), Large Rivers. Geomorphology and Management. John Wiley \& Sons, New York, NY, 261-292.

Younes, A.I., Engelder, T., Bosworth, W., 1998. Fracture distribution in faulted basement blocks: Gulf of Suez, Egypt. Geological Society, London, Special Publications 127 (1), 167-190.

Youssef, M.I., 1968. Structural Pattern of Egypt and Its Interpretation. AAPG Bulletin 52 (4), $601-614$.

Youssef, M.M., 2003. Structural setting of central and south Egypt An overview. Micropaleontology 49 (1), 1-14.

Ziegler, P.A., Cloetingh, S., 2004. Dynamic processes controlling evolution of rifted basins. Earth-Science Reviews 64 (1-2), 1-50. 